\title{
Room-Temperature Decarboxylative Alkynylation of Carboxylic Acids Using Photoredox Catalysis and EBX Reagents
}

\author{
Franck Le Vaillant, ${ }^{[a]}$ Thibaut Courant ${ }^{[b]}$ and Jerome Waser ${ }^{*[a]}$ \\ Dedication ((optional))
}

\begin{abstract}
Alkynes are used as building blocks in synthetic and medicinal chemistry, chemical biology and materials science. Therefore, efficient methods for their synthesis are the subject of intensive research. Herein, we report the synthesis of alkynes directly from broadly available carboxylic acids at room temperature under visible light irradiation. The combination of an iridium photocatalyst with EthynylBenziodoXolone (EBX) reagents allowed the decarboxylative alkynylation of carboxylic acids in good yields under mild conditions. The method could be applied to the transfer of silyl-, aryl- and alkyl- substituted alkynes. It was especially successful in the case of $\alpha$-amino and $\alpha$-oxo acids derived from the biomass.
\end{abstract}

Alkynes are among the most versatile functional groups in synthetic chemistry, as they are sufficiently stable, yet reactive enough to be easily modified. These properties made them ideally suited for applications not only in organic synthesis, but also in chemical biology and materials science (Scheme 1). ${ }^{[1]}$ All potential applications remain tributary of an efficient synthesis of alkynes. In particular, the metalcatalyzed Sonogashira cross-coupling is now broadly applied to access acetylenes (Scheme 1, A) ${ }^{[2]}$ However, the Sonogashira reaction requires starting materials functionalized with adequate leaving groups, which themselves need to be introduced into the molecules. New approaches are urgently needed to make the synthesis of structurally diverse alkynes more efficient. To meet this challenge, the direct alkynylation of $\mathrm{SP}^{2[3]}$ or $\mathrm{SP}^{3[4]} \mathrm{C}-\mathrm{H}$ bonds has been intensively investigated in the last decade (Scheme 1, B). Nevertheless, many of these methods still suffer from harsh conditions, limited scope and the need for directing groups or adjacent heteroatoms to control the selectivity in $\mathrm{C}-\mathrm{H}$ functionalization.

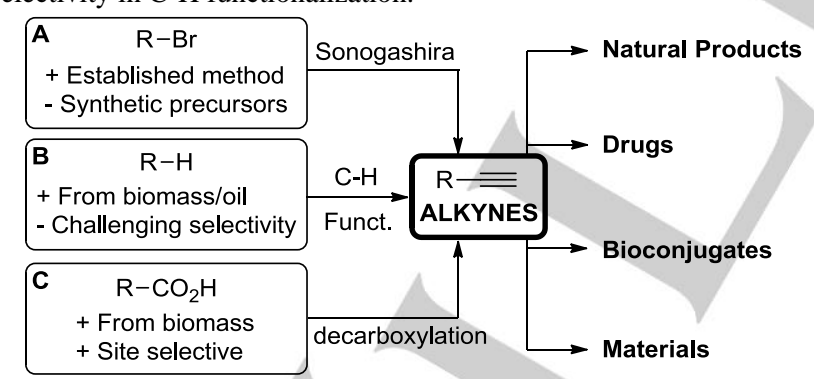

Scheme 1. Synthesis and applications of alkynes.

As an alternative to classical cross-coupling or $\mathrm{C}-\mathrm{H}$ functionalization, decarboxylative methods have recently attracted strong interest (Scheme 1, C) ${ }^{[5]}$ Indeed, the required carboxylic acids starting materials are derived from the biomass, and are therefore often even

[a] Mr. Franck Le Vaillant, Dr. Thibaut Courant and Prof. Dr. Jerome Waser

Laboratory of Catalysis and Organic Synthesis

Ecole Polytechnique Fédérale de Lausanne

EPFL SB ISIC LCSO, BCH 4306, 1015 Lausanne, $\mathrm{CH}$

E-mail: jerome.waser@epfl.ch

Homepage: http://lcso.epfl.ch/

[b] New address: Laboratoire de Chimie \& Biochimie Pharmacologique et Toxicologique. Université Paris-Descartes. CNRS-UMR 8601. 45 rue des Saints-Pères, 75006 Paris.

cheaper than the corresponding $\mathrm{C}-\mathrm{H}$ compounds. Furthermore, the carboxy group allows controlling the site of functionalization and only carbon dioxide is generated as waste. Despite these advantages, examples of decarboxylative alkynylation of aliphatic carboxylic acids are rare (Scheme 2). In 2009, Chao-Jun $\mathrm{Li}$ and co-workers reported the decarboxylative alkynylation of amino acids using a copper catalyst and di-tert-butyl peroxide as stoichiometric oxidant at $110^{\circ} \mathrm{C}$ (Scheme 2, A) ${ }^{[6]}$ In 2010, Seidel and co-workers ${ }^{[7]}$ and Chao-Jun Li and coworkers ${ }^{[8]}$ used the condensation of aldehydes or ketones instead of the peroxide oxidant (Scheme 2, B). The copper-catalyzed method was extended to $\alpha$-cyano carboxylic acids by $\mathrm{Xu}$ and co-workers in 2013 using alkynyl bromides (Scheme 2, C) ${ }^{[9]}$ Finally, in 2012, Chaozhong $\mathrm{Li}$ and co-workers reported a different approach based on the oxidative generation of radicals from carboxylic acids using a persulfate and a silver catalyst at $50{ }^{\circ} \mathrm{C}$ (Scheme 2, D) ${ }^{[10]}$ Key for success was the use of ethynylbenziodoxolone (EBX, 1) reagents, a class of reagents discovered by Ochiai and Zhdankin ${ }^{[11]}$ and intensively investigated by our group ${ }^{[12]}$ and others, ${ }^{[13]}$ to intercept the formed radical. Nevertheless, the use of these methods remains limited by the higher temperatures needed and/or the use of strong stoichiometric oxidants.

A) C. J. Li and co-workers, $2009^{[6]}$

$\mathrm{R}^{1} \mathrm{R}^{2} \mathrm{~N}$

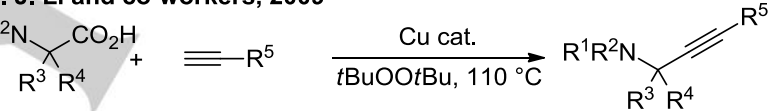

B) C. J. Li and co-workers and Seidel and coworkers, $2010^{[7,8]}$

$\mathrm{R}^{2} \mathrm{R}^{1} \mathrm{R}^{\mathrm{CO}_{2} \mathrm{H}}+\equiv \mathrm{R}^{4}$

C) $\mathrm{Xu}$ and co-workers, $2013^{[9]}$

$\mathrm{NC} \times \mathrm{CO}_{2} \mathrm{H}$

$\mathrm{R}^{1} \mathrm{R}^{2}$

$\mathrm{Br}=\mathrm{R}^{3}$

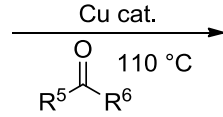

$\mathrm{R}_{\mathrm{R}^{3} \mathrm{R}^{4}}^{\mathrm{R}^{5}} \mathrm{R}^{\mathrm{R}^{5}}$

D) C. Li and co-workers, $2012^{[10]}$

$\stackrel{\mathrm{R}^{2} \mathrm{R}^{3}}{\mathrm{CO}_{2} \mathrm{H}} \underset{\mathrm{K}_{2} \mathrm{~S}_{2} \mathrm{O}_{8}, 50^{\circ} \mathrm{C}}{\stackrel{\mathrm{R} \text { cat. }}{\mathrm{R}_{\mathrm{R}^{2}} \mathrm{R}^{3}}}$

E) Chen and co-workers, $2015^{[16 a]}$

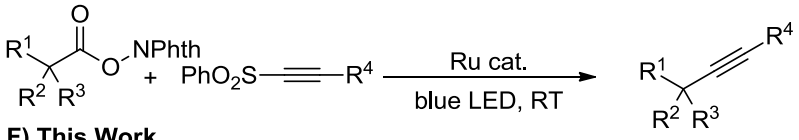

F) This Work

$\underset{\text { Free Acids }}{\mathrm{R}^{2} \mathrm{R}^{3}+\mathrm{O}} \underset{\begin{array}{c}\text { blue LED, RT } \\ \text { Room Temperature }\end{array}}{\mathrm{R}^{4}}$<smiles>[R]C#CC([R9])([R])[3H]</smiles>

Scheme 2. Synthesis of acetylenes via decarboxylative alkynylation.

In order to develop a decarboxylative alkynylation method under milder conditions, we envisaged the use of photoredox catalysis. ${ }^{[14]}$ Indeed, this approach has been highly successful for the decarboxylative functionalization of carboxylic acids recently. ${ }^{[15]}$ In 2015, Chen and co-workers reported a decarboxylative alkynylation method with alkynyl sulfones as reagents ${ }^{[16]}$ but in this case activation of the carboxylic acid as a N-hydroxy phthalimide ester was required, ${ }^{[17]}$ which diminished the efficiency of the reaction (Scheme 2, E). Based on the exceptional reactivity of EBX reagents, we considered them to be well-suited for the development of a photoredox 
process starting directly from the free acids. Indeed, Chen and coworkers had demonstrated that EBX reagents were compatible with a photoredox process in the alkynylation or boronic acid esters. ${ }^{[13 g]}$ Herein, we report a method for the decarboxylative alkynylation of free carboxylic acids under photoredox conditions (Scheme 2, F). The reaction proceeds at room temperature for a broad range of acids, and allow the introduction of silyl, alkyl and aryl- substituted alkynes.

We started our investigations with Cbz-protected proline (2a) as substrate using iridium complex $\mathbf{3 a}$ as photocatalyst and simple commercially available blue LED as light source (Table 1). Similar conditions had been highly successful in the work of MacMillan and co-workers. ${ }^{[15 \mathrm{~d}-\mathrm{h}]}$ We decided to target specifically silylated alkynes as products, as they give easy access to the most versatile terminal acetylenes. Gratifyingly, using TIPS-EBX (1a) as reagent ${ }^{[18]}$ and cesium acetate as base, the desired alkynylation product $\mathbf{4 a}$ could be isolated in $31 \%$ yield (entry 1). Intensive investigation of the reaction conditions showed that both structure and amount of the base were essential to obtain a good yield. ${ }^{[19]}$ With four equivalents of cesium acetate, the yield could be raised to $68 \%$ (entry 2). Other acetate salts such as potassium and sodium acetates were less efficient (entries 3-4). Cesium carbonate gave the desired product $\mathbf{4 a}$ in $35 \%$ yield only (entry 5). ${ }^{[20]}$ The best yield $(74 \%)$ was finally obtained using cesium benzoate as base (entry 6). 68\% yield of $\mathbf{4 a}$ were also obtained with catalyst $\mathbf{3 b}$, whereas the use of other iridium (3c and $\mathbf{3 d}$ ) and ruthenium (3e and $\mathbf{3 f}$ ) complexes or organocatalyst $\mathbf{3 g}$ did not lead to formation of the desired product (entries 7-12). A final optimization of base stoichiometry, concentration and reaction flask finally allowed to improve the yield to $92 \%$ using commercially available catalyst 3a (entry 13) ${ }^{[21]}$ As a final control, we then decided to examine other alkynylation reagents under the optimized reaction conditions (entries 14-17). With benziodoxole $\mathbf{1 b}, 38 \%$ of $\mathbf{4 a}$ was obtained (entry 14), whereas no product was formed with alkynyliodonium salt 1c, (entry 15). Alkyne 4a could be still obtained in $82 \%$ yield using simple alkynyl iodide 1d (entry 16). Although the yield was lower than with EBX reagent 1a, this result is noteworthy and well in line with the alkynylation of $\mathrm{C}-\mathrm{H}$ bonds under photoredox conditions using alkynyl iodides recently developed by Hashmi and co-workers. ${ }^{[4 \mathrm{~d}]}$ No product was obtained when using alkynyl sulfone 1e as reagent (entry 17).

With optimized conditions in hand we investigated the scope of the decarboxylative alkynylation (Scheme 3). We started with the examination of amino acids (Scheme 3, A). On preparative scale with only $0.5 \mathrm{~mol} \%$ of catalyst 3a, both Cbz- and Boc- protected proline derivatives $\mathbf{4 a}$ and $\mathbf{4 b}$ could be obtained in $90 \%$ yield. Piperidine $\mathbf{4 c}$ could also be obtained in $66 \%$ yield. Tetrahydroquinoline $4 \mathbf{d}$ was formed in $87 \%$ yield. This result is particularly interesting when considering that direct $\mathrm{C}-\mathrm{H}$ alkynylation cannot be used to obtain this regioisomer, as the $\mathrm{C}-\mathrm{H}$ bond adjacent to the benzene ring is more reactive. The reaction was not limited to cyclic amino acids: propargylic amine $4 \mathbf{e}$ could also be isolated in $70 \%$ yield.

We then turned to the alkynylation of $\alpha$-oxo acids (Scheme 3, B). Alkynylated tetrahydrofuran $\mathbf{4 f}$ could be obtained in quantitative yield. The reaction also worked well in case of a pyran derivative (product $\mathbf{4 g}$ ) or simple acyclic substrates (product $\mathbf{4 h}$ and $\mathbf{4 i}$ ). As an example of formation of an alkyne at a tertiary position, we attempted the more challenging functionalization of the drug fenofibric acid, which has been extensively used to treat hyperlipidemia and diabetes. ${ }^{[23]}$ Gratifyingly, the desired product $\mathbf{4 j}$ could still be obtained in $47 \%$ yield. Finally, carboxylic acids lacking the adjacent heteroatom were examined (Scheme 3, C). The desired products were obtained in moderate yields without further optimization for secondary (products $\mathbf{4 k}$ and $\mathbf{4 l}$ ) and tertiary (product $\mathbf{4 m}$ ) carboxylic acids.

The scope of alkynes in the decarboxylative alkynylation reaction was examined next (Scheme 4). In the case of silyl alkynes, a bulky group was required: The TBDPS protected proline derivative $4 \mathbf{n}$ was obtained in $78 \%$ yield, whereas no product could be isolated with TES or TMS groups (results not shown). This is probably due to the lower stability of these reagents under basic conditions. Aryl substituted EBX reagents worked very well in the alkynylation process giving products 4o-s in $62-97 \%$ yield. In particular, the introduction of bromidesubstituted benzene rings in $\mathbf{4 r}$ and $4 \mathbf{s}$ will allow easy further functionalization. Finally, EBX reagents bearing both primary and tertiary alkyl groups could also be used (products $\mathbf{4 t}$ and $\mathbf{4 u}$ ).
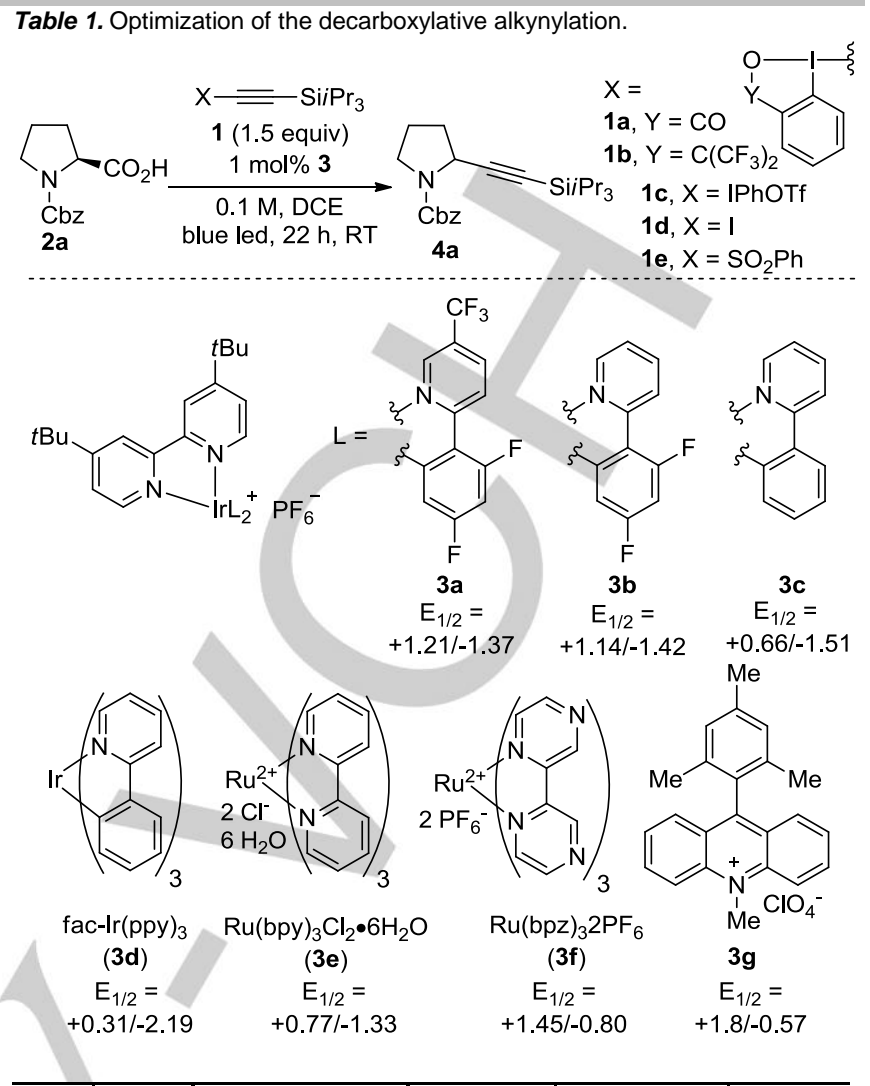

\begin{tabular}{|c|c|c|c|c|c|}
\hline entry & catalyst & base & reagent & conversion $^{[\mathrm{a}]}$ & yield $^{[b]}$ \\
\hline 1 & $3 a$ & 1.1 equiv $\mathrm{CsOAc}$ & $1 a$ & $>95 \%$ & $31 \%$ \\
\hline 2 & 3a & 4.0 equiv $\mathrm{CsOAc}$ & $1 \mathrm{a}$ & $>95 \%$ & $68 \%$ \\
\hline 3 & $3 a$ & 4.0 equiv $\mathrm{KOAc}$ & $1 a$ & $<50 \%$ & $9 \%$ \\
\hline 4 & $3 a$ & 4.0 equiv $\mathrm{NaOAc}$ & $1 a$ & $<50 \%$ & $22 \%$ \\
\hline 5 & $3 a$ & 4.0 equiv $\mathrm{Cs}_{2} \mathrm{CO}_{3}$ & 1a & $>95 \%$ & $35 \%$ \\
\hline 6 & $3 a$ & 4.0 equiv $\mathrm{CsOBz}$ & 1a & $>95 \%$ & $74 \%$ \\
\hline 7 & $3 b$ & 4.0 equiv $\mathrm{CsOBz}$ & $1 \mathrm{a}$ & $>95 \%$ & $68 \%$ \\
\hline 8 & $3 c$ & 4.0 equiv $\mathrm{CsOBz}$ & $1 a$ & $<10 \%$ & $<5 \%$ \\
\hline 9 & $3 d$ & 4.0 equiv $\mathrm{CsOBz}$ & $1 a$ & $<10 \%$ & $<5 \%$ \\
\hline 10 & $3 e$ & 4.0 equiv $\mathrm{CsOBz}$ & $1 a$ & $<10 \%$ & $<5 \%$ \\
\hline 11 & $3 f$ & 4.0 equiv $\mathrm{CsOBz}$ & $1 \mathrm{a}$ & $<10 \%$ & $<5 \%$ \\
\hline 12 & $3 g$ & 4.0 equiv $\mathrm{CsOBz}$ & $1 a$ & $<10 \%$ & $<5 \%$ \\
\hline $13^{[c]}$ & $3 a$ & 3.0 equiv $\mathrm{CsOBz}$ & $1 a$ & $>95 \%$ & $92 \%$ \\
\hline $14^{[\mathrm{c}]}$ & $3 a$ & 3.0 equiv $\mathrm{CsOBz}$ & $1 b$ & $>95 \%$ & $38 \%$ \\
\hline $15^{[c]}$ & $3 a$ & 3.0 equiv $\mathrm{CsOBz}$ & 1c & $>95 \%$ & $<5 \%$ \\
\hline $16^{[c]}$ & $3 a$ & 3.0 equiv $\mathrm{CsOBz}$ & 1d & $>95 \%$ & $82 \%$ \\
\hline $17^{[c]}$ & $3 \mathbf{a}$ & 3.0 equiv $\mathrm{CsOBz}$ & $1 e$ & $>95 \%$ & $<5 \%$ \\
\hline
\end{tabular}

${ }^{[a]}$ Reaction conditions: Using $0.1 \mathrm{mmol} 2 \mathrm{2a}$ (1 equiv), $0.15 \mathrm{mmol} 1$ (1.5 equiv), $\mu$ mol 3 ( 0.01 equiv) in DCE $(1 \mathrm{~mL})$ for $22 \mathrm{~h}$ at RT. The conversion of $2 \mathrm{a}$ by NMR is given. The values for reduction potentials are given in volts for catalyst $\mathbf{3}$ in relation to SCE, except for $\mathbf{3 b}$ which is reported relatively to ferrocene. ${ }^{14}$ ${ }^{22]}\left[{ }^{[b]}\right.$ Isolated yield after preparative TLC. ${ }^{[\mathrm{c}]}$ In $0.5 \mathrm{~mL}$ DCE.

We then wondered if the reaction could also be run using natural sun light. Indeed, product $\mathbf{4 a}$ was obtained in $88 \%$ yield after only five hours at room temperature when the reaction flask was directly exposed to sun light (Scheme $5, \mathbf{A}) \cdot{ }^{[24]}$ One of the main advantages of the alkynylation using TIPS-EBX (1a) is that the obtained products are easily deprotected to give the versatile terminal acetylenes. For example, proline derivative $4 \mathbf{a}$ was obtained on the one mmol scale in $89 \%$ yield. Desilylation and [3+2] cycloaddition with benzyl azide gave then triazole $\mathbf{5}$ in $90 \%$ yield (Scheme $5, \mathbf{B}$ ). 


\begin{tabular}{|c|c|c|}
\hline & 0.5 mol\% $3 a, 1.5$ equiv $1 \mathbf{a}$ & \\
\hline $0.30 \mathrm{mmol}$ & $\begin{array}{c}3.0 \text { equiv } \mathrm{CsOBz}, 0.2 \mathrm{M} \text {, DCE } \\
\text { blue LED, } 22 \mathrm{~h}, \mathrm{RT}\end{array}$ & 4 \\
\hline
\end{tabular}

\section{A. $\alpha$-Amino Acids}

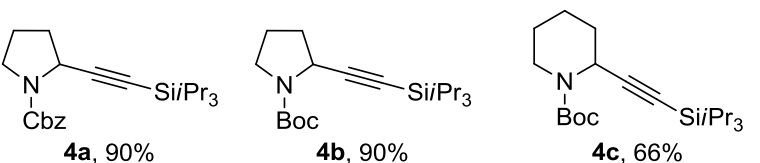

4a, $90 \%$

$\mathrm{SiiPr}_{3}$<smiles>CC(=O)OC(=O)NCC#C[SnH2]</smiles>

4d, $87 \%$

$4 e, 70 \%$

B. $\alpha$-Oxo Acids<smiles>CCCCOCC#C[SiH2][Mg][13CH3]</smiles><smiles>CC(C)(C)[SiH]C#CCOc1ccc(C(C)(C)C)cc1</smiles>

4i, $84 \%$ 4g, $60 \%$

$$
r_{3}
$$

4h, $88 \%^{[a]}$

\section{Other Acids}<smiles>C#C[SiH2]CC1CCCC1</smiles>

4k, $64 \%^{[\mathrm{b}]}$<smiles>CC#C[SiH2][AsH2]</smiles>

4I, $48 \%[\mathrm{c}]$

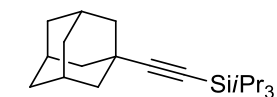

$4 \mathrm{~m}, 44 \%[\mathrm{c}]$
Scheme 3. Scope of carboxylic acids in the decarboxylative alkynylation. ${ }^{[a]}$ NMR yield. ${ }^{[b]}$ Using 1 mol\% of catalyst 3a. ${ }^{[c]}$ Using 2 mol\% of catalyst 3a.
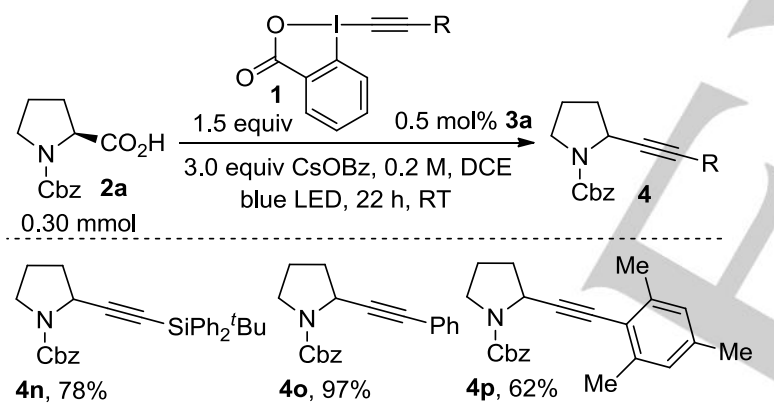

4o, $97 \%$

4p, $62 \% \quad$<smiles>O=C([O-])N1CCCC1C#Cc1ccc(C(F)(F)F)cc1</smiles>

$4 q, 85 \%$<smiles>O=C(OCc1ccccc1)OC(=O)N1CCCC1C#Cc1ccccc1Br</smiles>

4s, $88 \%$

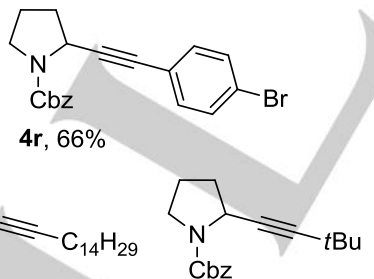

$\mathrm{Cbz}$
Scheme 4. Scope of alkynes in the decarboxylative alkynylation. ${ }^{[a]}$ Using 1 $\mathrm{mol} \%$ of catalyst $\mathbf{3 a}$.

In the future, in-depth investigations will be needed to gain a good understanding of the reaction mechanism. Nevertheless, based on the extensive research already done in the field of photoredox catalysis, ${ }^{[14,15]}$ a tentative mechanism can be proposed (Scheme 6). The catalytic cycle would start with the activation of the iridium catalyst 3 by visible light, which occurs at $380 \mathrm{~nm}$ for $\mathbf{3 a}$. The obtained activated complex I has a reduction potential of $+1.21 \mathrm{~V}$ and should be able to oxidize the cesium carboxylate of protected proline derivatives (reduction potential of $+0.95 \mathrm{~V}$ for the Boc protected derivative $\mathbf{2 b}$ ). ${ }^{[15 \mathrm{f}]}$

This would lead to reduced iridium complex II and $\alpha$-amino radical III. Addition of III onto EBX reagent 1 in $\alpha$ position to the iodine could then lead to adduct IV, although addition on the $\beta$ position followed by 1,2 - shift or a concerted mechanism cannot be excluded at this stage. $\beta$-elimination of iodine radical $\mathbf{V}$ then would lead to alkynylation product 4 . A final key step of the catalytic cycle would be then reduction of radical $\mathbf{V}$ by iridium complex II to give cesium salt $\mathbf{6}$ and regenerate catalyst $\mathbf{3}$. With $\mathbf{3 a}$, Ir $^{\text {II }}$ complex II is an especially strong reductant, with a reduction potential of $-1.37 \mathrm{~V}$. This is higher than most of the tested catalysts, and could explain the exceptional performance of 3a. A similar mechanism could be proposed with alkynyl iodide, as reduction of a potentially formed iodine radical is easy (reduction potential of $+1.3 \mathrm{~V}$ ). ${ }^{[25]}$

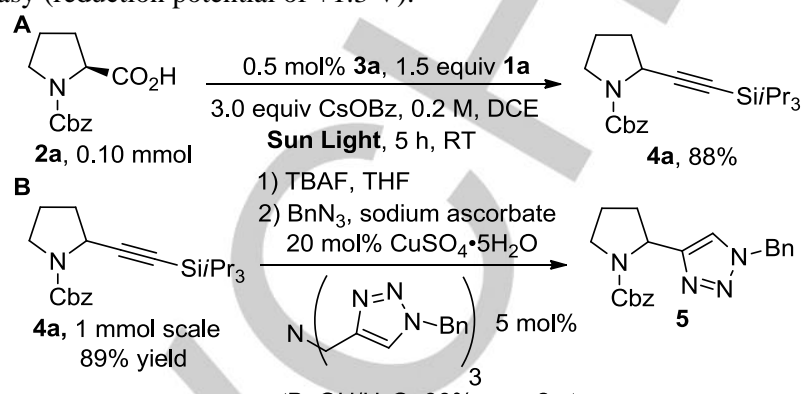

tBuOH$/ \mathrm{H}_{2} \mathrm{O}, 90 \%$ over 2 steps

Scheme 5. Reaction with natural sun light $(\mathbf{A})$ and derivatization of product $\mathbf{4 a}$ (B).

In conclusion, we have reported the decarboxylative alkynylation of free carboxylic acids proceeding under photoredox catalysis. The process can be done at room temperature using visible light with only $0.5 \mathrm{~mol} \%$ of an iridium photocatalyst. $\alpha$-amino acids could be converted to the corresponding alkynes in good yields. The process was also successful in the case of $\alpha$-oxo acids and simple aliphatic carboxylic acids and could be applied for the transfer of silyl-, aryland alkyl- substituted alkynes. The obtained products could be easily further functionalized. When considering the mild reaction conditions and broad functional group tolerance, the method is expected to become highly useful for the alkynylation of complex organic compounds and biomolecules in the future.

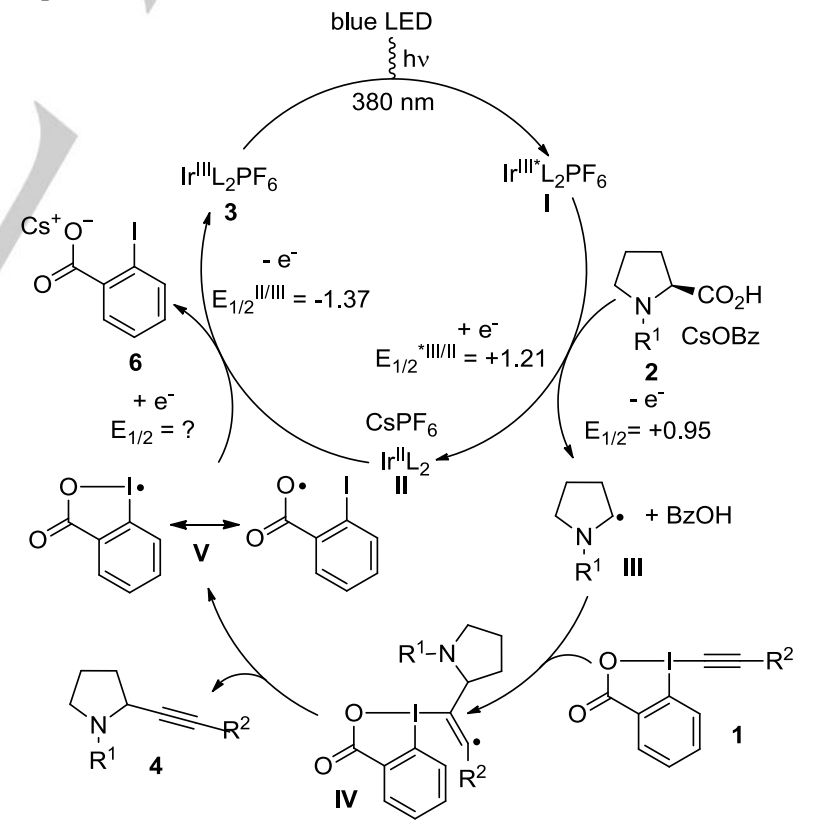

Scheme 6. Tentative mechanism for the decarboxylative alkynylation. The values for reduction potentials are given in volts for catalyst $3 \mathbf{a}$ and substrate $2 b$.

\section{Acknowledgements}

We thank ERC (European Research Council, Starting Grant iTools4MC, number 334840) and EPFL for financial support. Dr. Durga Hari, Mr. Daniele Perrotta and Ms. Paola Caramenti are further 
acknowledged for the synthesis of reagents and starting materials and for the purification and characterization of compounds.

Keywords: Photocatalysis, Alkynes, Carboxylic Acids, Hypervalent lodine, Amino Acids.

[1] F. Diederich, P. J. Stang, R. R. Tykwinski, Acetylene Chemistry: Chemistry, Biology and Material Science, F. Diederich, P. J. Stang, R. R. Tykwinski ed., Wiley-VCH, 2005.

[2] a) R. Chinchilla, C. Najera, Chem. Rev. 2007, 107, 874; b) R Chinchilla, C. Najera, Chem. Soc. Rev. 2011, 40, 5084.

[3] Reviews: a) A. S. Dudnik, V. Gevorgyan, Angew. Chem. 2010, 122 2140; Angew. Chem., Int. Ed. 2010, 49, 2096; b) S. Messaoudi, J. D. Brion, M. Alami, Eur. J. Org. Chem. 2010, 6495.

[4] Selected examples involving radical-based methods: a) J. Gong, P. L. Fuchs, J. Am. Chem. Soc. 1996, 118, 4486; b) A. P. Schaffner, V. Darmency, P. Renaud, Angew. Chem., Int. Ed. 2006, 45, 5847; c) T. Hoshikawa, S. Kamijo, M. Inoue, Org. Biomol. Chem. 2013, 11, 164 d) J. Xie, S. Shi, T. Zhang, N. Mehrkens, M. Rudolph, A. S. K Hashmi, Angew. Chem. 2015, 127, 6144; Angew. Chem., Int. Ed. $\mathbf{2 0 1 5}, 54,6046$.

[5] a) L. J. Gooßen, N. Rodríguez, K. Gooßen, Angew. Chem. 2008, 120 3144; Angew. Chem., Int. Ed. 2008, 47, 3100; b) N. Rodriguez, L. J. Goossen, Chem. Soc. Rev. 2011, 40, 5030.

[6] H.-P. Bi, L. Zhao, Y.-M. Liang, C.-J. Li, Angew. Chem. 2009, 121, 806; Angew. Chem., Int. Ed. 2009, 48, 792

7] C. Zhang, D. Seidel, J. Am. Chem. Soc. 2010, 132, 1798

[8] H.-P. Bi, Q. Teng, M. Guan, W.-W. Chen, Y.-M. Liang, X. Yao, C.-J Li, J. Org. Chem 2010, 75, 783 .

[9] Y.-S. Feng, Z.-Q. Xu, L. Mao, F.-F. Zhang, H.-J. Xu, Org. Lett. 2013 15,1472 .

[10] X. Liu, Z. Wang, X. Cheng, C. Li, J. Am. Chem. Soc. 2012, 134 14330.

[11] a) M. Ochiai, Y. Masaki, M. Shiro, J. Org. Chem. 1991, 56, 5511; b) V. V. Zhdankin, C. J. Kuehl, A. P. Krasutsky, J. T. Bolz, A. J. Simonsen, J. Org. Chem. 1996, 61, 6547.

[12] Selected examples: a) J. P. Brand, J. Charpentier, J. Waser, Angew. Chem. 2009, 121, 9510; Angew. Chem., Int. Ed. 2009, 48, 9346; b) D. Fernandez Gonzalez, J. P. Brand, J. Waser, Chem. Eur. J. 2010, 16 9457; c) S. Nicolai, S. Erard, D. Fernandez Gonzalez, J. Waser, Org. Lett. 2010, 12, 384; d) R. Frei, J. Waser, J. Am. Chem. Soc. 2013 , 135, 9620; e) Y. Li, J. P. Brand, J. Waser, Angew. Chem. 2013, 125, 6875; Angew. Chem., Int. Ed. 2013, 52, 6743; f) R. Frei, M. D Wodrich, D. P. Hari, P. A. Borin, C. Chauvier, J. Waser, J. Am Chem. Soc. 2014, 136, 16563; g) C. C. Chen, J. Waser, Chem Commun. 2014, 50, 12923; h) C. C. Chen, J. Waser, Org. Lett. 2015 17, 736; i) Y. Li, J. Waser, Angew. Chem. 2015, 127, 5528; Angew. Chem., Int. Ed. 2015, 54, 5438. Reviews: j) J. P. Brand, D Fernandez Gonzalez, S. Nicolai, J. Waser, Chem. Commun. 2011, 47 102; k) J. P. Brand, J. Waser, Chem. Soc. Rev. 2012, 41, 4165.

[13] Selected examples: a) H. Shi, L. Fang, C. Tan, L. Shi, W. Zhang, C. C. Li, T. Luo, Z. Yang, J. Am. Chem. Soc. 2011, 133, 14944; b) T. Aubineau, J. Cossy, Chem. Commun. 2013, 49, 3303; c) Z. Wang, X Li, Y. Huang, Angew. Chem. 2013, 125, 14208; Angew. Chem., Int Ed. 2013, 52, 14219; d) F. Xie, Z. Qi, S. Yu, X. Li, J. Am. Chem. Soc 2014, 136, 4780; e) K. D. Collins, F. Lied, F. Glorius, Chem. Commun. 2014, 50, 4459; f) C. Feng, T.-P. Loh, Angew. Chem. 2014 126, 2760; Angew. Chem., Int. Ed. 2014, 53, 2722; g) H. Huang, G. Zhang, L. Gong, S. Zhang, Y. Chen, J. Am. Chem. Soc. 2014, 136 , 2280; h) A. Nierth, M. A. Marletta, Angew. Chem. 2014, 126, 2649; Angew. Chem., Int. Ed. 2014, 53, 2611; i) L. F. Silva Jr, A. Utaka, L. Calvalcanti, Chem. Commun. 2014, 50, 3810; j) R.-Y. Zhang, L.-Y. $\mathrm{Xi}$, L. Zhang, S. Liang, S.-Y. Chen, X.-Q. Yu, RSC Advances 2014, 4,54349

[14] a) D. A. Nicewicz, D. W. C. MacMillan, Science 2008, 322, 77; b) T. P. Yoon, M. A. Ischay, J. Du, Nature Chemistry 2010, 2, 527; c) J. M. R. Narayanam, C. R. J. Stephenson, Chem. Soc. Rev. 2011, 40, 102 d) J. W. Tucker, C. R. J. Stephenson, J. Org. Chem. 2012, 77, 1617 e) J. Xuan, W.-J. Xiao, Angew. Chem. 2012, 124, 6934; Angew. Chem., Int. Ed. 2012, 51, 6828; f) C. K. Prier, D. A. Rankic, D. W. C. MacMillan, Chem. Rev. 2013, 113, 5322; h) D. M. Schultz, T. P. Yoon, Science 2014, 343, 985.

[15] a) L. Chen, C. S. Chao, Y. Pan, S. Dong, Y. C. Teo, J. Wang, C.-H Tan, Org. Biomol. Chem 2013, 11, 5922; b) Y Miyake, K. Nakajima, Y. Nishibayashi, Chem. Commun. 2013, 49, 7854; c) J.
Xie, P. Xu, H. Li, Q. Xue, H. Jin, Y. Cheng, C. Zhu, Chem. Commun. 2013, 49, 5672 ; d) Z. Zuo, D. T. Ahneman, L. Chu, J. A. Terrett, A. G. Doyle, D. W. C. MacMillan, Science 2014, 345, 437 ; e) L. Chu, C. Ohta, Z. Zuo, D. W. C. MacMillan, J. Am. Chem. Soc. 2014, 136, 10886; f) Z. Zuo, D. W. C. MacMillan, J. Am. Chem. Soc. 2014, 136 , 5257; g) A. Noble, S. J. McCarver, D. W. C. MacMillan, J. Am. Chem. Soc. 2015, 137, 624; h) S. Ventre, F. R. Petronijevic, D. W. C. MacMillan, J. Am. Chem. Soc. 2015, 137, 5654; i) J. Liu, Q. Liu, H. Yi, C. Qin, R. Bai, X. Qi, Y. Lan, A. Lei, Angew. Chem. 2014, 126 512; Angew. Chem., Int. Ed. 2014, 53, 502; j) M. Rueda-Becerril, O. Mahe, M. Drouin, M. B. Majewski, J. G. West, M. O. Wolf, G. M. Sammis, J.-F. Paquin, J. Am. Chem. Soc. 2014, 136, 2637; k) C. Cassani, G. Bergonzini, C.-J. Wallentin, Org. Lett. 2014, 16, 4228 ; 1) P. Xu, A. Abdukader, K. Hu, Y. Cheng, C. Zhu, Chem. Commun. 2014, 50, 2308

[16] a) J. Yang, J. Zhang, L. Qi, C. Hu, Y. Chen, Chem. Commun. 2015 51, 5275; During the preparation of this manuscript, Chen and coworkers as well as Wang and co-workers also reported the decarboxylative alkynylation of $\alpha$-keto acids. The methods remained limited to this class of substrates, however: b) H. Huang, G. Zhang, Y. Chen, Angew. Chem. 2015, 127, 7983; Angew. Chem., Int. Ed. 2015, 54, 7872; c) H. Tan, H. Li, W. Ji, L. Wang, Angew. Chem. 2015, 127, ; Angew. Chem., Int. Ed. 2015, 54, ASAP, DOI: 10.1002/anie.201503479.

[17] a) K. Okada, K. Okamoto, N. Morita, K. Okubo, M. Oda, J. Am Chem. Soc. 1991, 113, 9401; b) K. Okada, K. Okubo, N. Morita, M Oda, Tetrahedron Lett. 1992, 33, 7377; c) M. J. Schnermann, L. E. Overman, Angew. Chem. 2012, 124, 9714; Angew. Chem., Int. Ed. 2012, 51, 9576; d) G. L. Lackner, K. W. Quasdorf, L. E. Overman, J. Am. Chem. Soc. 2013, 135, 15342

[18] TIPS-EBX (1a) is commercially available. Alternatively, it can easily be synthesized in two steps from 2-iodobenzoic acid on $40 \mathrm{~g}$ scale: J. P. Brand, J. Waser, Synthesis 2012, 44, 1155.

[19] See Supporting Information for a full list of tested solvents and reaction conditions.

[20] The lower yield observed with this stronger base may be due to the sensitivity of silyl-EBX reagents to basic conditions leading to desilylation and decomposition. In fact, good yields were obtained also with cesium carbonate with aryl-substituted EBX reagents.

[21] See Supporting Information for details. No product was observed in the absence of either light or catalyst $\mathbf{3 a}$

[22] a) A. Singh, K. Teegardin, M. Kelly, K. S. Prasad, S. Krishnan, J. D. Weaver, J. Organomet. Chem. 2015, 776, 51-59; b) D. J. Wilger, N. J. Gesmundo, D. A. Nicewicz, Chem. Sci. 2013, 4, 3160

[23] a) J. A. Balfour, D. McTavish, R. C. Heel, Drugs 1990, 40, 260; b) A. Keech, R. J. Simes, P. Barter, J. Best, R. Scott, M. R. Taskinen, P. Forder, A. Pillai, T. Davis, P. Glasziou, P. Drury, Y. A. Kesaniemi, D. Sullivan, D. Hunt, P. Colman, M. d'Emden, M. Whiting, C. Ehnholm, M. Laakso, F. S. Investigators, Lancet 2005, 366, 1849; c) G. M. Keating, K. F. Croom, Drugs 2007, 67, 121.

[24] This experiment was performed in Lausanne $\left(46^{\circ} 51^{\prime} \mathrm{N}, 6^{\circ} 57^{\prime} \mathrm{E}\right)$ on May 29, 2015 from 12:00 to 17:00 with a light intensity of 600-850 W/m $\mathrm{m}^{2}$ according to: http://www.meteolausanne.com/soleil-et-uv.html. See supporting information for a detailed irradiation spectrum.

[25] P. Wardman, J. Phys. Chem. Ref. Data 1989, 18, 1637. We prefer this mechanism over an alternative pathway involving alkynyl radicals, due to the very high energy of the later (see ref. $4 \mathrm{~d}$ ). Data for the reduction potential of radical intermediate $\mathbf{V}$ are currently not available and difficult to obtain due to its high instability. 


\section{Entry for the Table of Contents}

\section{COMMUNICATION}

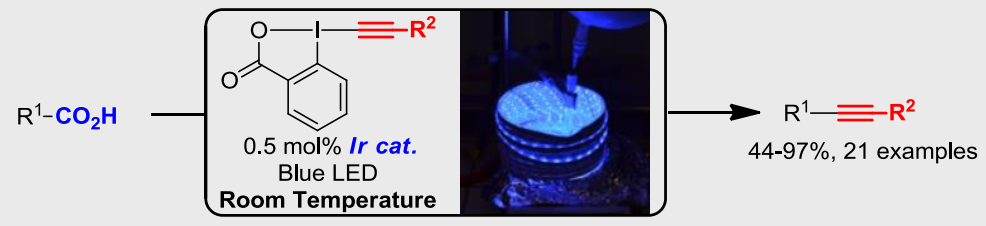

Alkynes are used as building blocks in synthetic and medicinal chemistry, chemical biology and materials science. Herein, we report the synthesis of alkynes directly from broadly available carboxylic acids proceeding at room temperature under visible light irradiation. The combination of an iridium photocatalyst with EthynylBenziodoXolone (EBX) reagents allowed the decarboxylative alkynylation of carboxylic acids in good yield under mild conditions.
Franck Le Vaillant, Thibaut Courant and Jerome Waser*

Page No. - Page No.

Room-Temperature Decarboxylative Alkynylation of Carboxylic Acids Using Photoredox Catalysis and EBX Reagents 


\section{Table of Contents}

1. General Methods $\quad$ S2

2. Preparation of Reagents and catalysts $\quad$ S3

3. Decarboxylative Alkynylation $\quad$ S18

4. Further Functionalization $\quad$ S29

5. Spectra for New Compounds $\quad$ S30 


\section{General method}

All reactions were carried out in oven dried glassware under an atmosphere of nitrogen, unless stated otherwise. For quantitative flash chromatography technical grade solvents were used. For flash chromatography for analysis, HPLC grade solvents from Sigma-Aldrich were used. THF, $\mathrm{Et}_{2} \mathrm{O}, \mathrm{CH}_{3} \mathrm{CN}$, toluene, hexane and $\mathrm{CH}_{2} \mathrm{Cl}_{2}$ were dried by passage over activated alumina under nitrogen atmosphere $\left(\mathrm{H}_{2} \mathrm{O}\right.$ content $<10 \mathrm{ppm}$, Karl-Fischer titration $)$. $\mathrm{NEt}_{3}$ and pyridine were distilled under nitrogen from $\mathrm{KOH}$. The solvents were degassed by FreezePump-Thaw method when mentioned. All chemicals were purchased from Acros, Aldrich, Fluka, VWR, Aplichem or Merck and used as such unless stated otherwise. All carboxylic acid starting materials were commercially available and used as received. Chromatographic purification was performed as flash chromatography using Macherey-Nagel silica 40-63, $60 \AA$, using the solvents indicated as eluent with 0.1-0.5 bar pressure.TLC was performed on Merck silica gel $60 \mathrm{~F}_{254}$ TLC glass plates or aluminium plates and visualized with UV light, permanganate stain, CAN stain or Anisaldehyde stain. Melting points were measured on a Büchi B-540 melting point apparatus using open glass capillaries, the data is uncorrected. ${ }^{1} \mathrm{H}-$ NMR spectra were recorded on a Brucker DPX-400 400 MHz spectrometer in chloroform-d, DMSO- $\mathrm{d}_{6}$ or $\mathrm{CD}_{3} \mathrm{OD}$, all signals are reported in ppm with the internal chloroform signal at $7.26 \mathrm{ppm}$, the internal DMSO signal at $2.50 \mathrm{ppm}$ or the internal methanol signal at $3.30 \mathrm{ppm}$ as standard. The data is being reported as $(\mathrm{s}=$ singlet, $\mathrm{d}=$ doublet, $\mathrm{t}=$ triplet, $\mathrm{q}=$ quadruplet, qi $=$ quintet, $\mathrm{m}=$ multiplet or unresolved, $\mathrm{br}=$ broad signal, app $=$ apparent, coupling constant(s) in $\mathrm{Hz}$, integration, interpretation). ${ }^{13} \mathrm{C}-\mathrm{NMR}$ spectra were recorded with ${ }^{1} \mathrm{H}$-decoupling on a Brucker DPX-400 $100 \mathrm{MHz}$ spectrometer in chloroform-d, DMSO- $\mathrm{d}_{6}$ or $\mathrm{CD}_{3} \mathrm{OD}$, all signals are reported in ppm with the internal chloroform signal at $77.0 \mathrm{ppm}$, the internal DMSO signal at $39.5 \mathrm{ppm}$ or the internal methanol signal at $49.0 \mathrm{ppm}$ as standard. Infrared spectra were recorded on a JASCO FT-IR B4100 spectrophotometer with an ATR PRO410-S and a ZnSe prisma and are reported as $\mathrm{cm}^{-1}(\mathrm{w}=$ weak, $\mathrm{m}=$ medium, $\mathrm{s}=$ strong, $\mathrm{br}=$ broad). High resolution mass spectrometric measurements were performed by the mass spectrometry service of ISIC at the EPFL on a MICROMASS (ESI) Q-TOF Ultima API. Reactions were performed in test tubes $(1.0$ to $10 \mathrm{~mL})$ which were hold using a rack for test tubes placed at the center of a crystallization flask, the latter was filled by water, in order to keep the temperature as constant as possible. On this flask were attached the blue LEDs (RUBAN LED 5MÈTRES - 60LED/M - 3528 BLEU - IP65 with Transformateur pour Ruban LED $24 \mathrm{~W} / 2 \mathrm{~A} / 12 \mathrm{~V}$, bought directly on RubanLED.com). The distance between the LEDs and the test tubes was approximatively $5 \mathrm{~cm}$. Long irradiation resulted in temperature increasing up to $34^{\circ} \mathrm{C}$ during overnight reactions. 


\section{Preparation of Reagents and Catalysts}

The synthesis of reagents $\mathbf{1 a - 1} \mathbf{j}$ and $\mathbf{1 n - 1 0}$ had already been described before by our group. The procedures are taken from the indicated publications to facilitate reproduction of the results by having all data in the same file. Catalysts $\mathbf{3 a}$ and $\mathbf{3 c - g}$ are commercially available and were used as received. $\mathbf{3 b}$ was synthesized as indicated below.

\section{1-Hydroxy-1,2-benziodoxol-3-(1H)-one (8)}<smiles>O=C(O)c1ccccc1I</smiles>

7

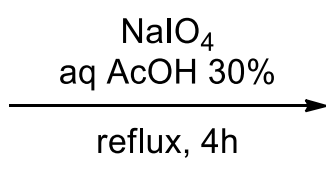

reflux, $4 \mathrm{~h}$<smiles>O=C1OI(O)c2ccccc21</smiles>

8

Following a reported procedure, ${ }^{[1]} \mathrm{NaIO}_{4}(7.24 \mathrm{~g}, 33.8 \mathrm{mmol}, 1.05$ equiv) and 2-iodobenzoic acid (7) (8.00 g, $32.2 \mathrm{mmol}, 1.00$ equiv) were suspended in $30 \%$ (v:v) aq. AcOH (48 mL). The mixture was vigorously stirred and refluxed for $4 \mathrm{~h}$. The reaction mixture was then diluted with cold water $(180 \mathrm{~mL})$ and allowed to cool to $\mathrm{rt}$, protecting it from light. After $1 \mathrm{~h}$, the crude product was collected by filtration, washed on the filter with ice water $(3 \times 20 \mathrm{~mL})$ and acetone $(3 \times 20 \mathrm{~mL})$, and air-dried in the dark to give the pure product 8 ( $8.3 \mathrm{~g}, 31 \mathrm{mmol}$, $98 \%)$ as a colorless solid.

${ }^{1} \mathrm{H}$ NMR (400 MHz, $\left.\left(\mathrm{CD}_{3}\right)_{2} \mathrm{SO}\right) \delta 8.02(\mathrm{dd}, 1 \mathrm{H}, J=7.7,1.4 \mathrm{~Hz}, \operatorname{ArH}), 7.97(\mathrm{~m}, 1 \mathrm{H}, \mathrm{ArH})$, $7.85(\mathrm{dd}, 1 \mathrm{H}, J=8.2,0.7 \mathrm{~Hz}, \operatorname{Ar} H), 7.71(\mathrm{td}, 1 \mathrm{H}, J=7.6,1.2 \mathrm{~Hz}, \mathrm{Ar} H) ;{ }^{13} \mathrm{C} \mathrm{NMR}(100$ $\left.\mathrm{MHz},\left(\mathrm{CD}_{3}\right)_{2} \mathrm{SO}\right) \delta 167.7,134.5,131.5,131.1,130.4,126.3,120.4$; IR v $3083(\mathrm{w}), 3060(\mathrm{w})$, $2867(\mathrm{w}), 2402$ (w), 1601 (m), 1585 (m), 1564 (m), 1440 (m), 1338 (s), 1302 (m), 1148 (m), $1018(\mathrm{w}), 834(\mathrm{~m}), 798(\mathrm{w}), 740(\mathrm{~s}), 694(\mathrm{~s}), 674(\mathrm{~m}), 649(\mathrm{~m})$; the reported values correspond to the ones in literature. ${ }^{[1]}$

\section{Triisopropylsilyl trimethylsilylacetylene (10)}

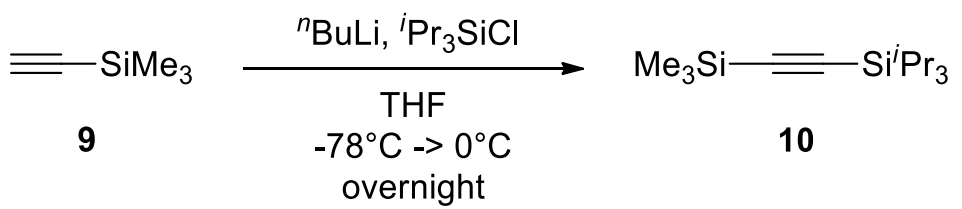

Following a reported procedure, ${ }^{[2]} n$-butyllithium $(2.5 \mathrm{M}$ in hexanes, $12.0 \mathrm{~mL}, 29.9 \mathrm{mmol}$, 0.98 equiv) was added dropwise to a stirred solution of ethynyltrimethylsilane (9) $(3.0 \mathrm{~g}, 30$ mmol, 1.0 equiv) in THF $(48 \mathrm{~mL})$ at $-78^{\circ} \mathrm{C}$. The mixture was then warmed to $0{ }^{\circ} \mathrm{C}$ and stirred for $5 \mathrm{~min}$. The mixture was then cooled back to $-78{ }^{\circ} \mathrm{C}$ and chlorotriisopropylsilane $(6.4 \mathrm{~mL}$, $30 \mathrm{mmol}, 1.0$ equiv) was added dropwise. The mixture was then allowed to warm to room temperature and stirred overnight. A saturated solution of ammonium chloride $(40 \mathrm{~mL})$ was added, and the reaction mixture was extracted with diethyl ether $(2 \times 60 \mathrm{~mL})$. The organic layer was washed with water and brine, then dried over $\mathrm{MgSO}_{4}$, filtered and concentrated under reduced pressure to obtain a colorless liquid which was further purified by Kugelrohr 
distillation $\left(56-57^{\circ} \mathrm{C} / 0.25 \mathrm{mmHg}\right)$ to yield $\mathbf{1 0}(7.16 \mathrm{~g}, 28.0 \mathrm{mmol}, 92 \%$ yield $)$ as a colorless liquid.

${ }^{1} \mathrm{H}$ NMR (400 MHz, $\left.\mathrm{CDCl}_{3}\right) \delta 1.08$ (m, $\left.21 \mathrm{H}, \mathrm{TIPS}\right), 0.18$ (s, $\left.9 \mathrm{H}, \mathrm{TMS}\right)$. IR v 2959 (m), 2944 (m), 2896 (w), 2867 (m), $1464(\mathrm{w}), 1385$ (w), 1250 (m), 996 (w), 842 (s), 764 (s), 675 (m), $660(\mathrm{~m})$. Characterization data of 10 corresponded to the literature values. ${ }^{[2]}$

\section{1-[(Triiso-propylsilyl)ethynyl]-1,2-benziodoxol-3(1H)-one (TIPS-EBX, 1a)}<smiles>O=C1OI(O)c2ccccc21</smiles>

8

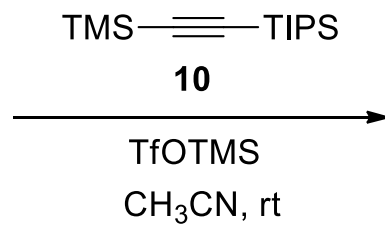

$\mathrm{CH}_{3} \mathrm{CN}$, rt<smiles>O=C1OI(C#CS[InH])c2ccccc21</smiles>

$1 a$

Following a reported procedure, ${ }^{[3]}$ 2-iodosylbenzoic acid (8) $(21.7 \mathrm{~g}, 82.0 \mathrm{mmol}, 1.0$ equiv) was charged in oven-dried three-neck 1L flask equipped with a magnetic stirrer. After 3 vacuum/nitrogen cycles, anhydrous acetonitrile $(500 \mathrm{~mL})$ was added via canula and cooled to $0{ }^{\circ} \mathrm{C}$. Trimethylsilyltriflate $(16.4 \mathrm{~mL}, 90.0 \mathrm{mmol}, 1.1$ equiv) was added dropwise via a dropping funnel over $30 \mathrm{~min}$ (no temperature increase was observed). After $15 \mathrm{~min}$, (trimethylsilyl)(triisopropylsilyl)acetylene (10) (23.0 g, $90.0 \mathrm{mmol}, 1.1$ equiv) was added via canula over $15 \mathrm{~min}$ (no temperature increase was observed). After $30 \mathrm{~min}$, the suspension became an orange solution. After $10 \mathrm{~min}$, pyridine $(7.0 \mathrm{~mL}, 90 \mathrm{mmol}, 1.1$ equiv) was added via syringe. After $15 \mathrm{~min}$, the reaction mixture was transferred in a one-neck 1L flask and reduced under vacuum until a solid was obtained. The solid was dissolved in DCM (200 mL) and transferred in a 1L separatory funnel. The organic layer was added and washed with $1 \mathrm{M}$ $\mathrm{HCl}(200 \mathrm{~mL})$ and the aqueous layer was extracted with $\mathrm{CH}_{2} \mathrm{Cl}_{2}(200 \mathrm{~mL})$. The organic layers were combined, washed with a saturated solution of $\mathrm{NaHCO}_{3}(2 \times 200 \mathrm{~mL})$, dried over $\mathrm{MgSO}_{4}$, filtered and the solvent was evaporated under reduced pressure. Recrystallization from acetonitrile ( $\mathrm{ca} 120 \mathrm{~mL}$ ) afforded $1 \mathrm{a}(30.1 \mathrm{~g}, 70.2 \mathrm{mmol}, 86 \%$ ) as colorless crystals.

$\mathrm{Mp}$ (Dec.) $170-176{ }^{\circ} \mathrm{C} .{ }^{1} \mathrm{H}$ NMR $\left(400 \mathrm{MHz}, \mathrm{CDCl}_{3}\right) \delta 8.44(\mathrm{~m}, 1 \mathrm{H}, \mathrm{ArH}), 8.29(\mathrm{~m}, 1 \mathrm{H}$, $\operatorname{Ar} H), 7.77$ (m, $2 \mathrm{H}, \mathrm{ArH}), 1.16$ (m, $21 \mathrm{H}$, TIPS). ${ }^{13} \mathrm{C} \mathrm{NMR}\left(100 \mathrm{MHz}, \mathrm{CDCl}_{3}\right) \delta 166.4,134.6$, 132.3, 131.4, 131.4, 126.1, 115.6, 114.1, 64.6, 18.4, 11.1. IR v $2943(\mathrm{~m}), 2865(\mathrm{~m}), 1716(\mathrm{~m})$, 1618 (m), 1604 (s), 1584 (m), 1557 (m), 1465 (m), 1439 (w), 1349 (m), 1291 (m), 1270 (w), 1244 (m), 1140 (m), 1016 (m), 999 (m), 883 (m), 833 (m), 742 (m), 702 (s), 636 (m); Characterization data of $1 \mathbf{a}$ corresponded to the literature values. ${ }^{[3]}$

1-Chloro-1,3-dihydro-3,3-bis(trifluoromethyl)-1,2-benziodoxole (13)

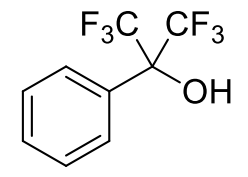

11

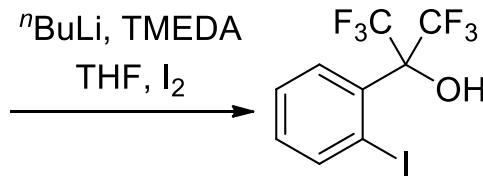

12

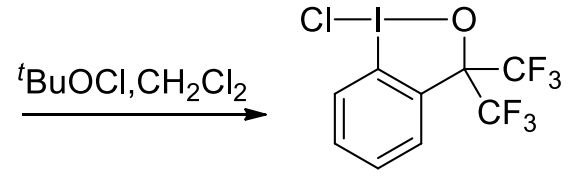

13

[3] J. P. Brand, J. Waser, Angew. Chem., Int. Ed. 2010, 49, 7304. 
Following a reported procedure, ${ }^{[4]}$ TMEDA (distilled over $\left.\mathrm{KOH}\right)(1.26 \mathrm{~mL}, 8.20 \mathrm{mmol}, 0.2$ equiv) was added to a solution of ${ }^{n} \mathrm{BuLi}(2.5 \mathrm{M}$ in hexanes, $36.6 \mathrm{~mL}, 91.6 \mathrm{mmol}, 2.2$ equiv). After $15 \mathrm{~min}$, the cloudy solution was cooled to $0{ }^{\circ} \mathrm{C}$ and $11(7.0 \mathrm{~mL}, 42 \mathrm{mmol}, 1$ equiv) in THF $(6 \mathrm{~mL})$ was added dropwise. The reaction was stirred $30 \mathrm{~min}$ at $0{ }^{\circ} \mathrm{C}$ and then at RT overnight. $\mathrm{I}_{2}\left(11.2 \mathrm{~g}, 44.0 \mathrm{mmol}, 1.06\right.$ equiv) was then added portion wise at $0{ }^{\circ} \mathrm{C}$ and the mixture stirred at $0{ }^{\circ} \mathrm{C}$ for $30 \mathrm{~min}$ and $4 \mathrm{~h}$ at $\mathrm{RT}$. The reaction was quenched with saturated $\mathrm{NH}_{4} \mathrm{Cl}$. Et $2 \mathrm{O}(100 \mathrm{~mL})$ was added and the layers were separated. The aqueous layer was then extracted twice with $\mathrm{Et}_{2} \mathrm{O}(3 \times 50 \mathrm{~mL})$. The organic layers were combined, washed twice with saturated $\mathrm{NaS}_{2} \mathrm{O}_{3}(2 \times 50 \mathrm{~mL})$, dried over $\mathrm{MgSO}_{4}$, filtered and reduced to afford $15.6 \mathrm{~g}$ of 12 as an brown oil which was used without further purification.

The crude oil was dissolved in wet $\mathrm{CH}_{2} \mathrm{Cl}_{2}(40 \mathrm{~mL})$ in the dark under air. ${ }^{t} \mathrm{BuOCl}(5.2 \mathrm{~mL}, 44$ mmol, 1.05 equiv) was then added dropwise at $0{ }^{\circ} \mathrm{C}$. After $30 \mathrm{~min}$, the resulting suspension was filtered to afford $\mathbf{1 3}(7.30 \mathrm{~g}, 18.1 \mathrm{mmol}, 43 \%)$ as a yellow solid. The mother liquors were carefully reduced to one third and filtered to afford $\mathbf{1 3}(3.51 \mathrm{~g}, 8.71 \mathrm{mmol}, 21 \%)$ as a yellow solid. Combined yield: $64 \%$.

Mp $167-169{ }^{\circ} \mathrm{C} .{ }^{1} \mathrm{H}$ NMR $\left(400 \mathrm{MHz}, \mathrm{CDCl}_{3}\right) \delta 8.09(\mathrm{~d}, 1 \mathrm{H}, J=8.4 \mathrm{~Hz}, \mathrm{ArH}), 7.85(\mathrm{~m}, 1 \mathrm{H}$, $\mathrm{ArH}), 7.73(\mathrm{~m}, 2 \mathrm{H}, \mathrm{ArH}) .{ }^{13} \mathrm{C} \mathrm{NMR}\left(101 \mathrm{MHz}, \mathrm{CDCl}_{3}\right) \delta 133.8,132.1,131.6,129.7,128.5$, 122.8 (q, $289 \mathrm{~Hz}), 113.4,84.8$. Consistent with reported values. ${ }^{[4]}$

\section{1-Hydroxy-3,3-bis(trifluoromethyl)-3-(1H)-1,2-benziodoxole (14)}

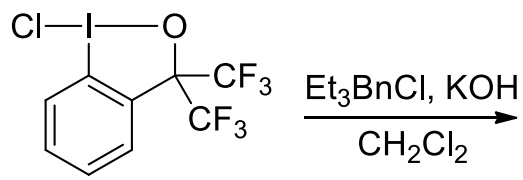

13<smiles>OI1OC(C(F)(F)F)(C(F)(F)F)c2ccccc21</smiles>

14

Following a preported procedure, ${ }^{[5]} \mathrm{Et}_{3} \mathrm{BnNCl}(83 \mathrm{mg}, 0.36 \mathrm{mmol}, 0.05$ equiv) was added to a stirring solution of $\mathbf{1 3}$ (10.7 g, $26.5 \mathrm{mmol}, 1$ equiv) in $\mathrm{CH}_{2} \mathrm{Cl}_{2}(150 \mathrm{~mL})$ and $\mathrm{KOH}(1.48 \mathrm{~g}$, $26.5 \mathrm{mmol}, 1$ equiv) in water $(28 \mathrm{~mL})$. The reaction was kept under air until TLC indicated that all starting material was consumed. The organic layer was separated and dried over $\mathrm{MgSO}_{4}$. The resulting solid was purified over a silica plug eluting with EtOAc, then recristallized in EtOAC (30 mL) and washed with pentane to afford 14 (7.42 g, $19.2 \mathrm{mmol}$, $73 \%$ ) as a white solid. ${ }^{1} \mathrm{H}$ NMR (400 MHz, DMSO) $\delta 7.96$ (m, $\left.2 \mathrm{H}, \mathrm{ArH}\right), 7.73$ (m, $\left.2 \mathrm{H}, \mathrm{ArH}\right)$. ${ }^{13} \mathrm{C}$ NMR (101 MHz, DMSO) $\delta 133.3,131.0,130.8,128.9,127.9,123.4(\mathrm{q}, J=290 \mathrm{~Hz})$, 117.2, 83.7 (m). IR $1464(\mathrm{w}), 1435$ (w), 1290 (w), 1263 (m), 1185 (s), 1139 (s), 1103 (m), $1041(\mathrm{w}), 1021(\mathrm{w}), 952(\mathrm{~s}), 760(\mathrm{~m}), 730(\mathrm{~m}), 692(\mathrm{~m})$.

\section{1-[(Triisopropylsilyl)ethynyl]-3,3-bis(trifluoromethyl)-3(1H)-1,2-benziodoxole (1b)}

[4] E. F. Perozzi, R. S. Michalak, G. D. Figuly, W. H. Stevenson, D. B. Dess, M. R. Ross, J. C. Martin, J. Org. Chem. 1981, 46, 1049.

[5] A. J. Blake, A. Novak, M. Davies, R. I. Robinson, S. Woodward, Synth. Commun. 2009, 39, 1065. 

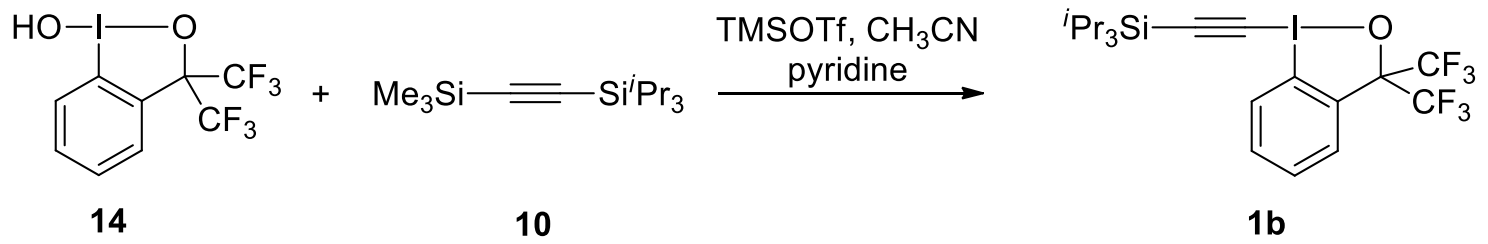

$1 b$

TMSOTf (3.80 g, $17.1 \mathrm{mmol}, 1.1$ equiv) was added to $\mathbf{1 4}$ (6.00 g, $15.5 \mathrm{mmol}, 1.0$ equiv) in $\mathrm{CH}_{2} \mathrm{Cl}_{2}(200 \mathrm{~mL})$ at $\mathrm{RT}$. After $20 \mathrm{~min}$, the solution was concentrated at $0{ }^{\circ} \mathrm{C}$ under reduced pressure. After evaporation of the solvent, the reaction flask was directly filled with Ar, to prevent decomposition of the hygroscopic triflate intermediate. Then the resulting yellow solid was dissolved in $\mathrm{CH}_{3} \mathrm{CN}$ (200 mL). (Trimethylsilyl)(triiso-propylsilyl)acetylene (10) (5.14 g, $20.2 \mathrm{mmol}, 1.3$ equiv) was added and after $20 \mathrm{~min}$ several drops of pyridine were added. The reaction was then concentrated under vacuum, dissolved in $\mathrm{Et}_{2} \mathrm{O}$ and filtered over a silica plug (eluant $\mathrm{Et}_{2} \mathrm{O}$ ). The resulting solid was recrystallized from pentane to afford $\mathbf{1 b}$ (5.43 g, $9.87 \mathrm{mmol}, 64 \%)$ as white crystals.

Rf (PET/Et $2 \mathrm{O}$ 95/5): 0.4. Mp $131-132{ }^{\circ} \mathrm{C} .{ }^{1} \mathrm{H}$ NMR (400 MHz, $\left.\mathrm{CDCl}_{3}\right)(\mathrm{ca} 0.10 \mathrm{mmol} / \mathrm{mL})$ $\delta 8.36(\mathrm{dd}, 1 \mathrm{H}, J=7.9,1.7 \mathrm{~Hz}, \operatorname{ArH}), 7.84(\mathrm{~d}, 1 \mathrm{H}, J=6.7 \mathrm{~Hz}, \operatorname{ArH}), 7.68(\mathrm{~m}, 2 \mathrm{H}, \mathrm{ArH})$, $1.15(\mathrm{~m}, 21 \mathrm{H}, \mathrm{TIPS}) .{ }^{13} \mathrm{C}$ NMR $\left(101 \mathrm{MHz}, \mathrm{CDCl}_{3}\right) \delta 132.7,131.1,129.9,129.9(\mathrm{~m}), 128.2$, 123.6 (q, $288 \mathrm{~Hz}), 112.1,110.8,81.4(\mathrm{~m}), 69.7,18.5,11.2$. Characterization data of $\mathbf{1 b}$ corresponded to the literature values. ${ }^{[6]}$

\section{Phenyl(triisopropylsilyl)iodonium triflate (1c)}<smiles>CC(=O)OI(OC(C)=O)c1ccccc1</smiles>

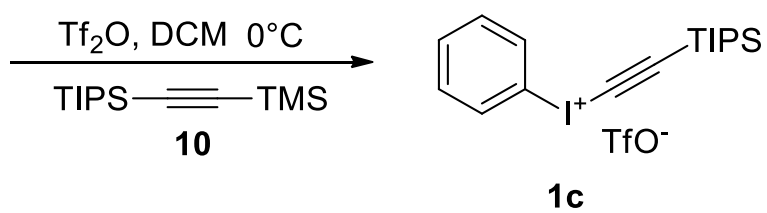

Following a slight modification of the reported procedure, ${ }^{[7]}$ phenyliodonium diacetate (15) (2.53 g, $7.85 \mathrm{mmol}, 1.00$ equiv) was diluted with DCM (7 mL) and the mixture was stirred for 5 minutes. $\mathrm{Tf}_{2} \mathrm{O}(0.60 \mathrm{~mL}, 3.9 \mathrm{mmol}, 0.50$ equiv. $)$ was added dropwise at $0{ }^{\circ} \mathrm{C}$ and the resulting yellow mixture was stirred $30 \mathrm{~min}$. (Trimethylsilyl)(triisopropylsilyl)acetylene (10) ( $2.00 \mathrm{~g}, 7.86 \mathrm{mmol}, 1.00$ equiv) was added and the mixture was then stirred $2 \mathrm{~h}$. Water was then added $(30 \mathrm{~mL})$ followed by extraction of the aqueous layer with DCM $(2 \times 30 \mathrm{~mL})$. The combined organic layers were dried over $\mathrm{MgSO}_{4}$, filtered and the solvent was evaporated under reduced pressure. The resulting solid was triturated in hexane $(10 \mathrm{~mL})$. Filtration and removal of solvent in vacuo afforded phenyl(triisopropylsilyl)iodonium triflate (1c) $(2.90 \mathrm{~g}$, $11.2 \mathrm{mmol}, 70 \%$ yield) as a colorless solid.

Melting point: $109-114{ }^{\circ} \mathrm{C} .{ }^{1} \mathrm{H}$ NMR $\left(400 \mathrm{MHz}, \mathrm{CDCl}_{3}\right) \delta 8.09(\mathrm{~m}, 2 \mathrm{H}, \mathrm{ArH}), 7.65(\mathrm{~m}, 1 \mathrm{H}$, $\operatorname{ArH}), 7.52$ (m, $2 \mathrm{H}, \mathrm{ArH}), 1.15-1.01$ (m, $21 \mathrm{H}, \mathrm{TIPS}) ;{ }^{13} \mathrm{C} \mathrm{NMR}\left(100 \mathrm{MHz}, \mathrm{CDCl}_{3}\right) \delta 133.7$, 132.5, 132.4, 119.7, 117.6, 117.6, 44.9, 18.3, 11.1; IR v 3288 (w), 3088 (m), 2949 (m), 2894

[6] Y. LI, J. Brand, J. Waser, Angew. Chem., Int. Ed. 2013, 52, 6743.

[7] T. Kitamura, M. Kotani, Y. Fujiwara, Synthesis 1998, 10, 1416. 
(m), 2869 (w), $1563(\mathrm{~m}), 1467(\mathrm{w}), 1451(\mathrm{w}), 1388(\mathrm{w}), 1281(\mathrm{~s}), 1236(\mathrm{~s}), 1221(\mathrm{~s}), 1174(\mathrm{~s})$, 1068 (w), 1028 (s), 988 (m), 916 (m), $884(\mathrm{~m}), 736$ (s), 679 (m), 639 (s); HRMS (ESI) calcd for $\mathrm{C}_{17} \mathrm{H}_{26} \mathrm{ISi}^{+}$(M-OTf) 385.0843; found 385.0812; the reported values corresponded to the ones in literature. ${ }^{[3]}$

2-Iodo-1-triisopropylsilyl acetylene (1d)

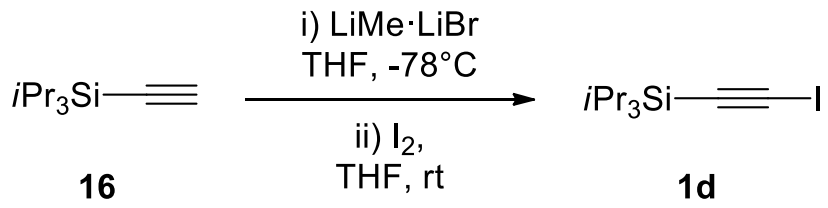

Following a reported procedure, ${ }^{[8]} \mathrm{MeLi} \cdot \mathrm{LiBr}(1.5 \mathrm{M}$ in diethyl ether, 1.1.mL, $1.6 \mathrm{mmol}$, 1.0 equiv) was added to a stirred solution of triisopropylsilylacetylene (16) $(0.36 \mathrm{~mL}, 1.6$ mmol, 1.0 equiv) in dry THF $(1.8 \mathrm{~mL})$, cooled at $-78^{\circ} \mathrm{C}$, and the mixture was allowed to react for $1 \mathrm{~h}$ at that temperature. A solution of $\mathrm{I}_{2}(457 \mathrm{mg}, 1.80 \mathrm{mmol}, 1.25$ equiv) in dry THF (2.7 $\mathrm{mL}$ ) was then added dropwise and the mixture was stirred for $1.5 \mathrm{~h}$ at $-78^{\circ} \mathrm{C}$. The mixture was then diluted with brine $(6 \mathrm{~mL})$ and the aqueous layer was extracted with ether $(3 \times 10 \mathrm{~mL})$. The combined organic layers were washed with a saturated aqueous solution of $\mathrm{Na}_{2} \mathrm{~S}_{2} \mathrm{O}_{3}(3 \mathrm{x}$ $20 \mathrm{~mL}$ ), dried over $\mathrm{MgSO}_{4}$ and concentrated under reduced pressure. Purification by column chromatography $\left(\mathrm{SiO}_{2}\right.$, hexane) afforded 2-iodo-1-triisopropylsilyl acetylene (1d) (0.470 g, $1.52 \mathrm{mmol}, 94 \%$ yield) as a colorless oil.

${ }^{1} \mathrm{H}$ NMR (400 MHz, $\left.\mathrm{CDCl}_{3}\right) \delta 1.10-1.04$ (m, $\left.21 \mathrm{H}, \mathrm{TIPS}\right) ;{ }^{13} \mathrm{C} \mathrm{NMR}\left(100 \mathrm{MHz}, \mathrm{CDCl}_{3}\right) \delta$ $100.8,18.5,11.4$ (one acetylene carbon was not resolved); the reported values correspond to the ones in literature. ${ }^{[8]}$

\section{Triisopropyl((phenylsulfonyl)ethynyl)silane (1e)}

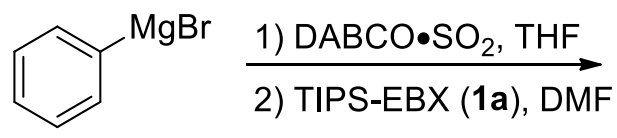

17

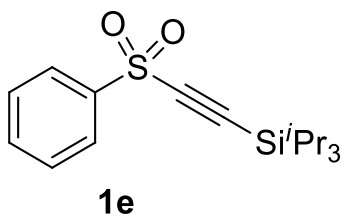

$1 e$

Following a reported procedure, ${ }^{[9]}$ a stirring bar was placed in a $7.5 \mathrm{~mL}$ microwave tube with a cap (not sealed at this moment), and flamed dry under high vacuum. After cooling down to r.t. and filled with nitrogen, DABSO (48 mg, $0.20 \mathrm{mmol}$ ) was added in to the microwave tube. The tube was sealed, evacuated and filled with nitrogen four times. Anhydrous THF $(0.65 \mathrm{~mL})$ was added, and the tube was replaced in a $-40{ }^{\circ} \mathrm{C}(\mathrm{MeCN}+$ dry ice) bath for $10 \mathrm{~min}$. Phenyl magnesium bromide (17) $(0.20 \mathrm{~mL}, 0.20 \mathrm{mmol})$ was added, and

[8] López S.; Fernández-Trillo F.; Midón P.; Castedo L.; Saá J. Org. Chem. 2005, 70, 6346.

[9] C. C. Chen, J. Waser, Org. Lett. 2015, 17, 736. 
the reaction mixture was stirred for $1 \mathrm{~h}$. The cooling bath was then removed, and the resulting solution was stirred at r.t. for another $1 \mathrm{~h}$.

The sealed cap was removed, and DMF $0.65 \mathrm{~mL}$ and TIPS-EBX (1a) (103 mg, 0.240 mmol) were subsequently added to the resulting solution and stirred for further $5 \mathrm{~min}$. The reaction was quenched by adding $1 \mathrm{M} \mathrm{HCl}(2 \mathrm{~mL})$. The resulting layers were separated and the aqueous layer was extracted with EtOAc $(3 \times 5 \mathrm{~mL})$. All of the organic layers were combined, washed with (sat.) $\mathrm{NaHCO}_{3}$, dried over $\mathrm{MgSO}_{4}$, and filtrated. The organic solvent was removed under reduced pressure to give the crude product. The crude product was purified by column chromatography to afford the desired product $1 \mathrm{e}$ as a colorless gel (55 $\mathrm{mg}$, $0.17 \mathrm{mmol}, 85 \%$ yield).

$\mathrm{R} f 0.5$ (pentane/EtOAc 5/1, $\mathrm{KMnO}_{4}$ ); pentane/EtOAc 5/1 was used as the eluting solvents for purification. ${ }^{1} \mathrm{H}-\mathrm{NMR}\left(400 \mathrm{MHz}, \mathrm{CDCl}_{3}\right) \delta 8.07-7.97(\mathrm{~m}, 2 \mathrm{H}, \mathrm{Ar}-H), 7.70-7.61(\mathrm{~m}, 1 \mathrm{H}$, Ar- $H$ ), 7.57 (ddd, $J=8.2,6.6,1.3 \mathrm{~Hz}, 2 \mathrm{H}, \mathrm{Ar}-H), 1.19-0.95$ (m, 21H, SiiPr 3 ). ${ }^{13} \mathrm{C}-\mathrm{NMR}$ $\left(101 \mathrm{MHz}, \mathrm{CDCl}_{3}\right) \delta 142.1,134.0,129.2,127.2,100.9,100.6,18.3,10.8$. IR 4352(w), 3853(w), 3661(s), 3227(w), 2939(br), 2124(w), 1934(w), 1452(m), 1407(s), 1407(s), 1251(s), 1055(s), 893(s), 795(m).

tertButyldiphenylsilyl trimethylsilylacetylene (18)

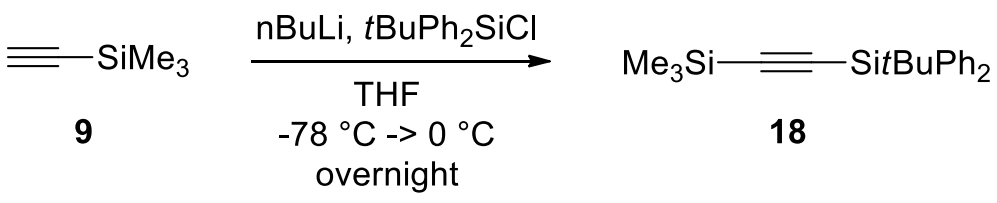

Following a reported procedure, ${ }^{[10]} n$-butyllithium $(2.5 \mathrm{M}$ in hexanes, $8.0 \mathrm{~mL}, 20 \mathrm{mmol}$, 0.98 equiv) was added dropwise to a stirred solution of ethynyltrimethylsilane (9) $(2.90 \mathrm{~mL}$, $20.4 \mathrm{mmol}, 1.0$ equiv) in THF $(30 \mathrm{~mL})$ at $-78{ }^{\circ} \mathrm{C}$. The mixture was then warmed to $0{ }^{\circ} \mathrm{C}$ and stirred for $5 \mathrm{~min}$. The mixture was then cooled back to $-78{ }^{\circ} \mathrm{C}$ and tertbutylchlorodiphenylsilane $(6.4 \mathrm{~mL}, 30 \mathrm{mmol}, 1.0$ equiv) was added dropwise. The mixture was then allowed to warm to room temperature and stirred overnight. A saturated solution of ammonium chloride $(30 \mathrm{~mL})$ was added, and the reaction mixture was extracted with diethyl ether $(2 \times 50 \mathrm{~mL})$. The organic layer was washed with water and brine, then dried over $\mathrm{MgSO}_{4}$, filtered and concentrated under reduced pressure to obtain a colorless liquid which was further purified by Kugelrohr distillation $\left(\mathrm{bp}=150^{\circ} \mathrm{C}, \mathrm{p}=0.25 \mathrm{mmHg}\right.$ ) to yield $\mathbf{1 8}(2.95$ $\mathrm{g}, 8.76 \mathrm{mmol}, 44 \%$ yield) as a colorless liquid.

${ }^{1} \mathrm{H}$ NMR (400 MHz, $\left.\mathrm{CDCl}_{3}\right) \delta 7.80(\mathrm{~m}, 4 \mathrm{H}, \mathrm{ArH}), 7.38(\mathrm{~m}, 6 \mathrm{H}, \mathrm{ArH}), 1.08(\mathrm{~s}, 9 \mathrm{H}, t \mathrm{Bu})$, 0.27 (s, 9H, TMS). ${ }^{13} \mathrm{C}$ NMR $\left(101 \mathrm{MHz}, \mathrm{CDCl}_{3}\right) \delta 135.6,133.2,129.5,127.7,119.0,108.7$, 27.0, 18.5, -0.0. The characterization data for compound 18 corresponded to the reported values. $^{[10]}$

\section{1-[(tertButyldiphenylsilyl)ethynyl]-1,2-benziodoxol-3(1H)-one (1f)}

[10] P. Cuadrado, A.M. Gonzalez-Nogal, R. Valero, Tetrahedron 2002, 58, 4975. 


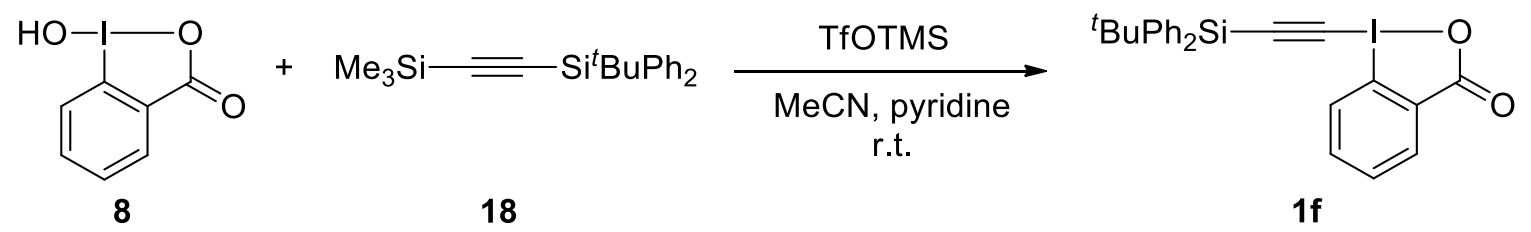

Following a reported procedure, ${ }^{[11]}$ trimethylsilyltriflate $(1.58 \mathrm{~mL}, 8.70 \mathrm{mmol}, 1.1$ equiv, freshly distilled) was added dropwise to a stirred solution of 2-iodosylbenzoic acid (8) (2.07 g, $7.90 \mathrm{mmol}, 1.0$ equiv) in acetonitrile $(30 \mathrm{~mL})$. Butyldiphenyl((trimethylsilyl)ethynyl)silane (18) (2.95 g, $3.70 \mathrm{mmol}, 1.1$ equiv) was then added dropwise, followed, after $15 \mathrm{~min}$, by the addition of pyridine $(710 \mu \mathrm{L}, 3.70 \mathrm{mmol}, 1.1$ equiv). The mixture was stirred $10 \mathrm{~min}$. The solvent was then removed under reduced pressure and the yellow crude oil was dissolved in dichloromethane. The organic layer was washed with $1 \mathrm{M} \mathrm{HCl}$ and the aqueous layer was extracted with $\mathrm{CH}_{2} \mathrm{Cl}_{2}$. The organic layers were combined, washed with a saturated solution of $\mathrm{NaHCO}_{3}$, dried over $\mathrm{MgSO}_{4}$, filtered and the solvent was evaporated under reduced pressure. The resulting oil was stirred in hexane and ether and then reduced under vacuum to afford a colorless solid. Recrystallization from acetonitrile ( $c a 20 \mathrm{~mL})$ afforded $\mathbf{1 f}(2.77 \mathrm{~g}$, $5.42 \mathrm{mmol}, 69 \%$ ) as a colorless solid.

${ }^{1} \mathrm{H} \mathrm{NMR}\left(400 \mathrm{MHz}, \mathrm{CDCl}_{3}\right)(c a 0.12 \mathrm{mmol} / \mathrm{mL}) \delta 8.43(\mathrm{~d}, J=6.5 \mathrm{~Hz}, 1 \mathrm{H}, \mathrm{ArH}), 8.29(\mathrm{~d}$, $J=8.2 \mathrm{~Hz}, 1 \mathrm{H}, \mathrm{ArH}), 7.82(\mathrm{~d}, J=6.6 \mathrm{~Hz}, 4 \mathrm{H}, \mathrm{ArH}), 7.75(\mathrm{t}, J=7.2 \mathrm{~Hz}, 1 \mathrm{H}, \operatorname{ArH}), 7.66(\mathrm{~m}$, $1 \mathrm{H}, \mathrm{ArH}), 7.53-7.41(\mathrm{~m}, 6 \mathrm{H}, \mathrm{ArH}), 1.21(\mathrm{~s}, 9 \mathrm{H}, t \mathrm{Bu}) .{ }^{13} \mathrm{C} \mathrm{NMR}\left(101 \mathrm{MHz}, \mathrm{CDCl}_{3}\right) \delta 166.6$, $135.5,134.8,132.4,131.5,131.3,130.2$, 128.1, 126.3, 116.0, 112.2, 68.5, 27.0, 18.7. One carbon was not resolved. IR $v_{\max } 3072$ (w), 2958 (w), 2932 (w), 2865 (w), 2860 (w), 2248 (w), 1649 (w), 1622 (m), 1561 (w), 1471 (w), 1430 (w), 1336 (w), 1297 (w), 1253 (w), 1113 (w), 1008 (w), 906 (s), 821 (w), 727 (s), 647 (m). The characterization data for compounds 1 f corresponded to the reported values. ${ }^{[11]}$

\section{Triethyl trimethylsilylacetylene (19)}

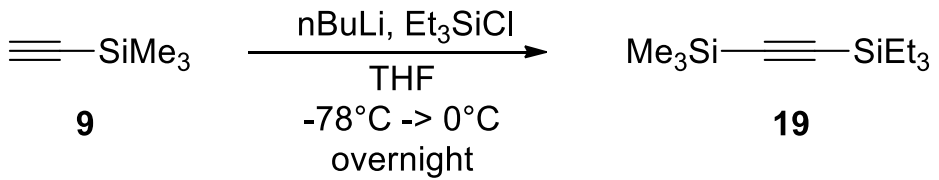

Following a reported procedure ${ }^{[10]} n$-butyllithium $(2.5 \mathrm{M}$ in hexanes, $5.4 \mathrm{~mL}, 14 \mathrm{mmol}$, 1.0 equiv) was added dropwise to a stirred solution of ethynyltrimethylsilane (9) (1.36 g, 13.8 mmol, 1.00 equiv) in THF $(21 \mathrm{~mL})$ at $-78{ }^{\circ} \mathrm{C}$. The mixture was then warmed to $0{ }^{\circ} \mathrm{C}$ and stirred for $5 \mathrm{~min}$. The mixture was then cooled back to $-78{ }^{\circ} \mathrm{C}$ and chlorotriethylsilane (2.3 $\mathrm{mL}, 14 \mathrm{mmol}, 0.98$ equiv) was added dropwise. The mixture was then allowed to warm to room temperature and stirred overnight. A saturated solution of ammonium chloride $(20 \mathrm{~mL})$ was added, and the reaction mixture was extracted with diethyl ether $(2 \times 20 \mathrm{~mL})$. The organic layer was washed with water and brine, then dried over $\mathrm{MgSO}_{4}$, filtered and

[11] J. P Brand, C. Chevalley, R. Scopelliti, J. Waser, Chem. Eur. J. 2012, 18, 5655. 
concentrated under reduced pressure to obtain a colorless liquid which was further purified by Kugelrohr distillation to yield 19 (3.4 g, $11 \mathrm{mmol}, 83 \%$ yield) as a colorless liquid.

${ }^{1} \mathrm{H}$ NMR (400 MHz, $\left.\mathrm{CDCl}_{3}\right) \delta 0.99\left(\mathrm{t}, J=7.9 \mathrm{~Hz}, 9 \mathrm{H}, \mathrm{SiCH}_{2} \mathrm{CH}_{3}\right), 0.59$ (q, $J=7.9 \mathrm{~Hz}, 6$ $\left.\mathrm{H}, \mathrm{SiCH}_{2} \mathrm{CH}_{3}\right), 0.17$ (s, $\left.9 \mathrm{H}, \mathrm{TMS}\right) .{ }^{13} \mathrm{C} \mathrm{NMR}\left(100 \mathrm{MHz}, \mathrm{CDCl}_{3}\right) \delta 115.4,111.2,7.4,4.4,0.0$. IR v $2958(\mathrm{~m}), 2913(\mathrm{~m}), 2879(\mathrm{~m}), 1462(\mathrm{w}), 1414(\mathrm{w}), 1381(\mathrm{w}), 1250(\mathrm{~m}), 1015$ (m), 973 (w), $908(\mathrm{w}), 844(\mathrm{~s}), 773$ (s), 731 (s), $702(\mathrm{sh}), 679(\mathrm{sh})$. Consistent with reported data. ${ }^{[12]}$

\section{1-[(Triethylsilyl)ethynyl]-1,2-benziodoxol-3(1H)-one (1g)}<smiles>O=C1OI(O)c2ccccc21</smiles>

8

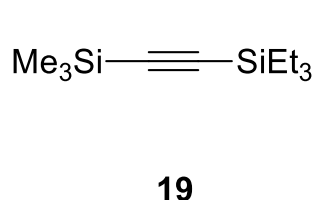

19

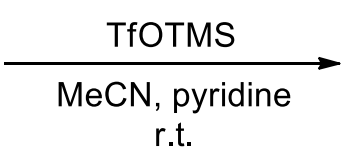

r.t.<smiles>CC[SiH2]C#CI1OC(=O)c2ccccc21</smiles>

$1 \mathrm{~g}$

Trimethylsilyltriflate $\left(2.78 \mathrm{~mL}, 15.4 \mathrm{mmol}, 1.1\right.$ equiv, freshly distilled over $\left.\mathrm{CaH}_{2}\right)$ was added dropwise to a stirred solution of 2-iodosylbenzoic acid (8) (3.71 g, $14.0 \mathrm{mmol}, 1.0$ equiv) in acetonitrile (50 mL). After $15 \mathrm{~min}$, (trimethylsilyl)(triethylsilyl)acetylene (19) (3.26 $\mathrm{g}, 15.4 \mathrm{mmol}, 1.1$ equiv) was then added dropwise. After 30 min pyridine $(1.25 \mathrm{~mL}, 15.4$ mmol, 1.1 equiv) was added and the mixture was stirred for an additional $15 \mathrm{~min}$. The solvent was then removed under reduced pressure and the yellow crude oil was dissolved in dichloromethane $(50 \mathrm{~mL})$. The organic layer was washed with $1 \mathrm{M} \mathrm{HCl}(50 \mathrm{~mL})$, and the aqueous layer was extracted with $\mathrm{CH}_{2} \mathrm{Cl}_{2}(50 \mathrm{~mL})$. The organic layers were washed twice with saturated $\mathrm{NaHCO}_{3}(75 \mathrm{~mL})$, dried over $\mathrm{MgSO}_{4}$, filtered and the solvent was evaporated under reduced pressure. The resulting solid was recristalized twice in $\mathrm{CH}_{3} \mathrm{CN}$. The solid was washed with cold acetonitirile, hexanes and dried under high vacuum to afford $\mathbf{1 g}$ (2.95 g, $7.64 \mathrm{mmol}, 55 \%$ yield) as a slightly brown solid.

$\mathrm{Mp}$ (Dec.) $155-158{ }^{\circ} \mathrm{C} .{ }^{1} \mathrm{H}$ NMR (400 MHz, $\left.\mathrm{CDCl}_{3}\right) \delta 8.40(\mathrm{~m}, 1 \mathrm{H}, \mathrm{ArH}), 8.24(\mathrm{~m}, 1 \mathrm{H}$, $\operatorname{ArH}$ ), 7.75 (m, $2 \mathrm{H}, \operatorname{ArH}), 1.06$ (t, $\left.J=8.0 \mathrm{~Hz}, 9 \mathrm{H}, \mathrm{SiCH}_{2} \mathrm{CH}_{3}\right), 0.73$ (q, J = 8.0 Hz; 6H, $\left.\mathrm{SiCH}_{2} \mathrm{CH}_{3}\right) .{ }^{13} \mathrm{C} \mathrm{NMR}\left(100 \mathrm{MHz}, \mathrm{CDCl}_{3}\right) \delta 166.5,134.8,132.5,131.6,131.3,126.1,115.5$, 115.1, 64.6, 7.4, 4.1. IR v $3064(\mathrm{w}), 3062(\mathrm{~m}), 2957(\mathrm{~m}), 2911(\mathrm{~m}), 2877(\mathrm{~m}), 1621(\mathrm{~s}), 1587$ (m), $1561(\mathrm{~m}), 1460(\mathrm{~m}), 1440(\mathrm{~m}), 1415(\mathrm{w}), 1378(\mathrm{w}), 1336(\mathrm{~m}), 1297(\mathrm{~m}), 1237$ (w), 1149 (w), 1113 (w), 1010 (m), 976 (w), 912 (w), 912 (w), 834 (m), 804 (w), 739 (s), 693 (m), 675 $(\mathrm{m}), 647(\mathrm{w})$. Consistent with reported data. ${ }^{[12]}$

\section{1-[(Trimethylsilyl)ethynyl]-1,2-benziodoxol-3(1H)-one (1h)}
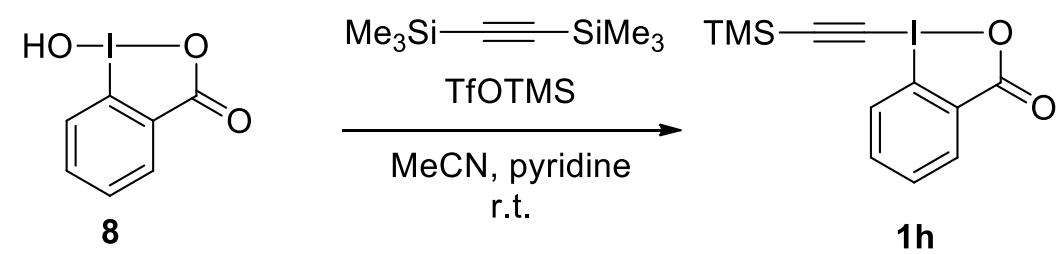

[12] Nicolai, S.; Piemontesi, C.; Waser, J. Angew. Chem., Int. Ed. 2011, 50, 4680 
Following a reported procedure, ${ }^{[13]}$ trimethylsilyltriflate $(2.8 \mathrm{~mL}, 15 \mathrm{mmol}, 1.4$ equiv, freshly distilled) was added dropwise to a stirred solution of 2-iodosylbenzoic acid (8) (3.00 g, $11.4 \mathrm{mmol}, 1.00$ equiv) in acetonitrile $(85 \mathrm{~mL})$ until the mixture turned colorless. Bis(trimethylsilyl)acetylene $(2.14 \mathrm{~g}, 12.5 \mathrm{mmol}, 1.10$ equiv) was then added dropwise, followed, after $20 \mathrm{~min}$, by the addition of pyridine (1.2 $\mathrm{mL}, 15 \mathrm{mmol}, 1.4$ equiv). The mixture was stirred $30 \mathrm{~min}$. The solvent was then removed under reduced pressure and the yellow crude oil was dissolved in dichloromethane $(80 \mathrm{~mL})$. The organic layer was washed with a large amount of water $(130 \mathrm{~mL})$, and the aqueous layer was extracted with $\mathrm{CH}_{2} \mathrm{Cl}_{2}$ (3 x 65 $\mathrm{mL})$. The organic layer was washed with brine $(130 \mathrm{~mL})$, dried over $\mathrm{MgSO}_{4}$, filtered and the solvent was evaporated under reduced pressure. Recrystallization from acetonitrile $(2.3 \mathrm{~mL})$ afforded $\mathbf{1 h}$ (2.35 g, $6.84 \mathrm{mmol}, 60 \%$ yield) as a colorless solid.

Mp: $143-145{ }^{\circ} \mathrm{C}(\mathrm{dec}) ;{ }^{1} \mathrm{H} \mathrm{NMR}\left(400 \mathrm{MHz}, \mathrm{CDCl}_{3}\right) \delta 8.42(\mathrm{dd}, J=6.4,1.9 \mathrm{~Hz}, 1 \mathrm{H}, \mathrm{Ar} H)$, $8.19(\mathrm{~m}, 1 \mathrm{H}, \operatorname{Ar} H), 7.78(\mathrm{~m}, 2 \mathrm{H}, \operatorname{ArH}), 0.32$ (s, 9H, TMS). ${ }^{13} \mathrm{C}$ NMR (100 MHz, $\left.\mathrm{CDCl}_{3}\right)$ 166.4, 134.9, 132.6, 131.7, 131.4, 126.1, 117.2, 115.4, 64.2, -0.5. IR $v_{\max } 3389(\mathrm{w}), 2967(\mathrm{w})$, 1617 (s), 1609 (s), 1562 (m), 1440 (w), 1350 (m), 1304 (w), 1254 (w), 1246 (w), 1112 (w), $1008(\mathrm{w}), 852(\mathrm{~s}), 746(\mathrm{~m}), 698(\mathrm{~m}), 639(\mathrm{~m})$. The characterization data for compounds $\mathbf{4 c}$ corresponded to the reported values. ${ }^{[13]}$

\section{1-[Phenylethynyl]-1,2-benziodoxol-3(1H)-one (Ph-EBX, 1i)}
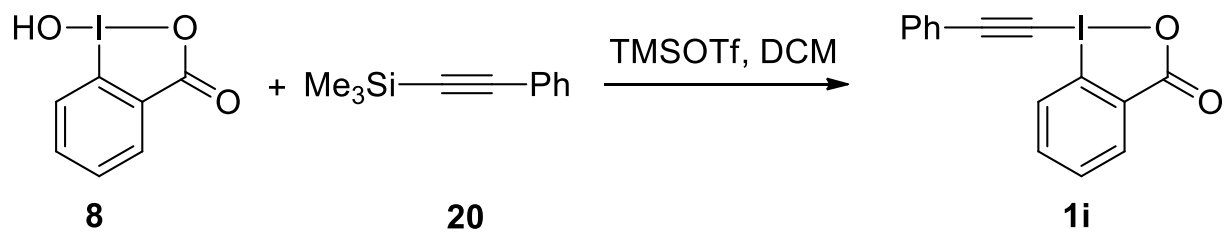

Following a reported procedure ${ }^{[11]}$ trimethylsilyltriflate $(1.60 \mathrm{~mL}, 8.56 \mathrm{mmol}, 1.1$ eq. $)$ was added dropwise to a stirred solution of 2-iodosylbenzoic Trimethylsilyl triflate $(7.50 \mathrm{~mL}, 41.5$ mmol, 1.1 equiv) was added to a suspension of 2-iodosylbenzoic acid (8) $(10.0 \mathrm{~g}, 37.7 \mathrm{mmol}$, 1 equiv) in $\mathrm{CH}_{2} \mathrm{Cl}_{2}(100 \mathrm{~mL})$ at $\mathrm{RT}$. The resulting yellow mixture was stirred for $1 \mathrm{~h}$, followed by the dropwise addition of trimethyl(phenylethynyl)silane (20) $(8.10 \mathrm{~mL}, 41.5 \mathrm{mmol}, 1.1$ equiv) (slightly exothermic). The resulting suspension was stirred for $6 \mathrm{~h}$ at RT, during this time a white solid was formed. A saturated solution of $\mathrm{NaHCO}_{3}(100 \mathrm{~mL})$ was then added and the mixture was stirred vigorously. The resulting suspension was filtered on a glass filter of porosity 4 . The two layers of the mother liquors were separated and the organic layer was washed with sat. $\mathrm{NaHCO}_{3}(100 \mathrm{~mL})$, dried over $\mathrm{MgSO}_{4}$, filtered and evaporated under reduced pressure. The resulting mixture was combined with the solid obtained by filtration and boiled in $\mathrm{CH}_{3} \mathrm{CN}$ (300 mL). The mixture was cooled down, filtered and dried under high vacuum to afford $\mathbf{1 i}(6.08 \mathrm{~g}, 17.4 \mathrm{mmol}, 46 \%)$ as a colorless solid.

$\mathrm{Mp}$ (Dec.) $155-160{ }^{\circ} \mathrm{C} .{ }^{1} \mathrm{H}$ NMR $\left(400 \mathrm{MHz}, \mathrm{CDCl}_{3}\right)(\mathrm{ca} 0.03 \mathrm{mmol} / \mathrm{ml}) \delta 8.46(\mathrm{~m}, 1 \mathrm{H}$, ArH), 8.28 (m, $1 \mathrm{H}, \mathrm{ArH}), 7.80$ (m, $2 \mathrm{H}, \mathrm{ArH}), 7.63$ (m, $2 \mathrm{H}, \mathrm{ArH}), 7.48$ (m, $3 \mathrm{H}, \mathrm{ArH}) .{ }^{13} \mathrm{C}$

[13] V. V.Zhdankin, C. J Kuehl, A. P Krasutsky, J. T. Bolz, A. J. Simonsen, J. Org. Chem. 1996, 61, 6547. 
NMR $\left(101 \mathrm{MHz}, \mathrm{CDCl}_{3}\right) \delta 163.9,134.9,132.9,132.5,131.6,131.3 .130 .8,128.8,126.2$, $120.5,116.2,106.6,50.2$. Consistent with reported data. ${ }^{[11]}$

\section{(Mesitylethynyl)trimethylsilane (22)}

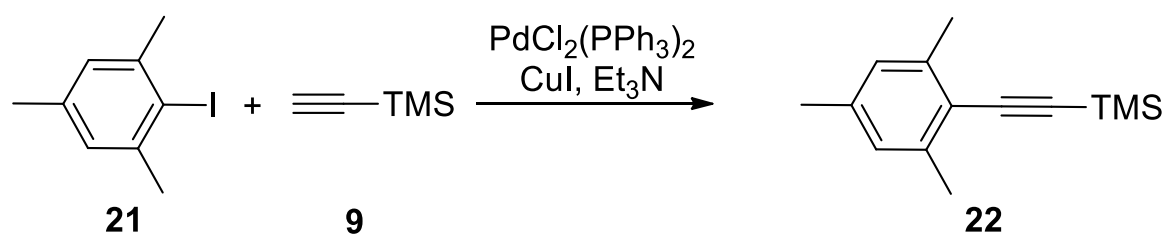

Following a reported procedure ${ }^{[11]}$ Iodomesitylene (21) (1.05 g, $4.27 \mathrm{mmol}, 1$ equiv) was dissolved in $\mathrm{Et}_{3} \mathrm{~N}(10 \mathrm{~mL})$ (without prior drying). After three freeze-thraw-pump cycle, $\mathrm{PdCl}_{2}\left(\mathrm{PPh}_{3}\right)_{2}$ (30 mg, $0.42 \mathrm{mmol}, 0.1$ equiv) and $\mathrm{CuI}$ (16 mg, $0.84 \mathrm{mmol}, 0.2$ equiv) were added under $\mathrm{N}_{2}$. After the addition of trimethylsilylacetylene (9) (1.2 mL, $8.5 \mathrm{mmol}, 2$ equiv), the green suspension was stirred at RT for $1 \mathrm{~h}$. The reaction mixture was reduced under vacuum, dissolved in $\mathrm{CH}_{2} \mathrm{Cl}_{2}(30 \mathrm{~mL})$, washed with $5 \%$ EDTA solution $(30 \mathrm{~mL})$ and water $(30 \mathrm{~mL})$. The organic layers were them dried over $\mathrm{MgSO}_{4}$, filtered and reduced under vacuum. The resulting oil was purified by column chromatography (PET) to afford 22 (526 mg, 2.43 mmol, $66 \%$ ) along with $15 \%$ of starting material.

$\mathrm{R}_{\mathrm{f}} 0.5$ (PET). ${ }^{1} \mathrm{H}$ NMR (400 MHz, $\left.\mathrm{CDCl}_{3}\right) \delta 6.87$ (s, $\left.2 \mathrm{H}, \mathrm{ArH}\right), 2.41\left(\mathrm{~s}, 6 \mathrm{H}, \mathrm{CH}_{3}\right), 2.29$ (s, $\left.3 \mathrm{H}, \mathrm{CH}_{3}\right), 0.28$ (s, $\left.9 \mathrm{H}, \mathrm{TMS}\right)$. Used without further purification.

\section{1-[2,4,6-Trimethylphenylethynyl]-1,2-benziodoxol-3(1H)-one (Mes-EBX, 1j)}

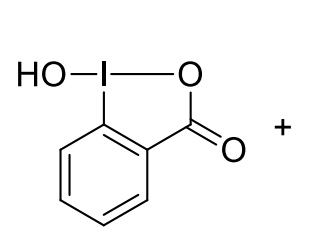

8

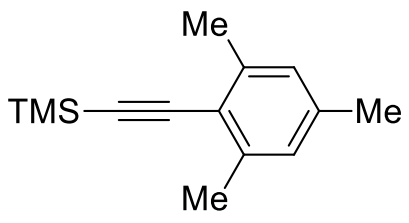

22

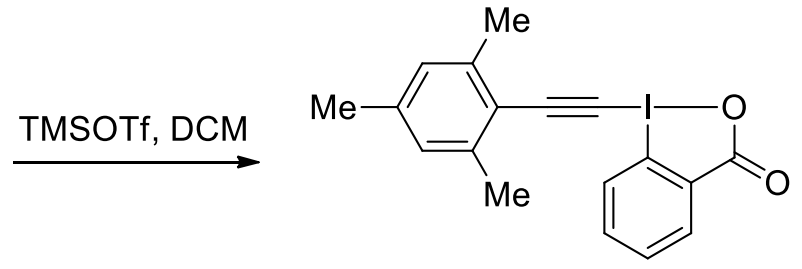

$1 \mathrm{j}$

Following a reported procedure, ${ }^{[11]}$ Trimethylsilyl triflate $(212 \mu \mathrm{L}, 1.15 \mathrm{mmol}, 1.1$ equiv) was added to a suspension of 2-iodosylbenzoic acid (8) (1.00 g, $1.05 \mathrm{mmol}, 1$ equiv) in $\mathrm{CH}_{2} \mathrm{Cl}_{2}$ (4 $\mathrm{mL}$ ) at RT. The resulting yellow mixture was stirred for $1 \mathrm{~h}$, followed by the dropwise addition of (mesitylethynyl)trimethylsilane (22) (250 mg, $1.15 \mathrm{mmol}, 1.1$ equiv) dissolved in $\mathrm{CH}_{2} \mathrm{Cl}_{2}(1 \mathrm{~mL})$. The resulting suspension was stirred for $6 \mathrm{~h}$ at RT. A saturated solution of $\mathrm{NaHCO}_{3}(5 \mathrm{~mL})$ was then added and the mixture was stirred vigorously. The layers were separated and the organic layer was washed with sat. $\mathrm{NaHCO}_{3}(10 \mathrm{~mL})$, dried over $\mathrm{MgSO}_{4}$, filtered and evaporated under reduced pressure. The resulting solid was recrystallized in $\mathrm{CH}_{3} \mathrm{CN}$ (ca $20 \mathrm{ml}$ ). The mother liquors were concentrated and and the obtained solid recrystallized in $\mathrm{CH}_{3} \mathrm{CN}$ (4 mL). Both solids were combined, washed with pentane and dried under high vacuum to afford $\mathbf{1 j}$ (120 $\mathrm{mg}, 0.307 \mathrm{mmol}, 30 \%)$ as a tan solid.

$\mathrm{Mp}$ (Dec.) $171-175{ }^{\circ} \mathrm{C} .{ }^{1} \mathrm{H} \mathrm{NMR}\left(400 \mathrm{MHz}, \mathrm{CDCl}_{3}\right)(\mathrm{ca} 0.01 \mathrm{mmol} / \mathrm{ml}) \delta 8.38(\mathrm{~m}, 1 \mathrm{H}$, ArH), 8.28 (m, $1 \mathrm{H}, \mathrm{ArH}), 7.72$ (m, $2 \mathrm{H}, \mathrm{ArH}), 6.92$ (s, $2 \mathrm{H}, \mathrm{MesH}), 2.45$ (s, $\left.6 \mathrm{H}, \mathrm{CH}_{3}\right), 2.31$ 
(s, $\left.3 \mathrm{H}, \mathrm{CH}_{3}\right) .{ }^{13} \mathrm{C} \mathrm{NMR}\left(101 \mathrm{MHz}, \mathrm{CDCl}_{3}\right) \delta 166.7,142.1,140.5,134.5,132.2,131.5,131.3$, 128.0, 126.2, 117.5, 116.5, 105.1, 55.6, 21.4, 21.0. IR 2979 (w), 2916 (w), 2247 (w), 2131 (w), $1650(\mathrm{~m}), 1623(\mathrm{~m}), 1562(\mathrm{w}), 1439(\mathrm{w}), 1333(\mathrm{w}), 1292(\mathrm{w}), 1212(\mathrm{w}), 1146(\mathrm{w}), 1008$ (w), $906(\mathrm{~s}), 855(\mathrm{w}), 833(\mathrm{w}), 729(\mathrm{~s}), 647(\mathrm{~m})$. Consistent with reported data. ${ }^{[11]}$

\section{Trimethyl((4-(trifluoromethyl)phenyl)ethynyl)silane (24)}
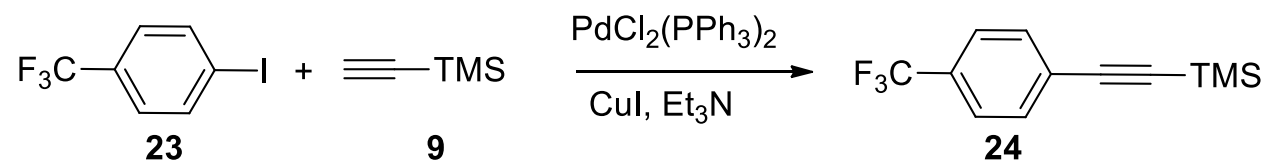

Following a slight modification of the reported procedure, ${ }^{[14]}$ a solution of trimethylsilyl acetylene (9) (2.13 mL, $15.0 \mathrm{mmol}, 1.5$ equiv) was added drop wise to a mixture of 1-iodo-4(trifluoromethyl) benzene (23) (2.72 g, $10.0 \mathrm{mmol}, 1$ equiv), $\mathrm{Pd}\left(\mathrm{PPh}_{3}\right)_{2} \mathrm{Cl}_{2}(70 \mathrm{mg}, 0.10$ mmol, 0.01 equiv), and copper (I) iodide ( $38 \mathrm{mg}, 0.20 \mathrm{mmol}, 0.02$ equiv) in triethylamine (30 $\mathrm{mL}$ ). The reaction mixture was stirred at room temperature for $3 \mathrm{~h}$, concentrated and purified by column chromatography (pure pentane) to afford the corresponding product $24(1.60 \mathrm{~g}$, $6.60 \mathrm{mmol}, 66 \%)$ as a colorless oil.

$\mathrm{R}_{\mathrm{f}} 0.8$ (pentane). ${ }^{1} \mathrm{H}$ NMR (400 MHz, $\mathrm{CDCl}_{3}$ ) $\delta 7.56$ (s, $4 \mathrm{H}, \mathrm{ArH}$ ), 0.27 (s, $9 \mathrm{H}, \mathrm{TMS}$ ). ${ }^{13} \mathrm{C}$ NMR $\left(101 \mathrm{MHz}, \mathrm{CDCl}_{3}\right) \delta 132.2,130.1(\mathrm{q}, J=32.5 \mathrm{~Hz}), 126.9(\mathrm{~m}), 125.1(\mathrm{q}, J=3.8 \mathrm{~Hz})$. $123.9(\mathrm{q}, J=272.1 \mathrm{~Hz}), 103.6,97.3,-0.04$. The characterization data for compound 24 corresponded to the reported values. ${ }^{[15]}$

\section{1-[4-Trifluoromethylphenylethynyl]-1,2-benziodoxol-3(1H)-one (1k)}

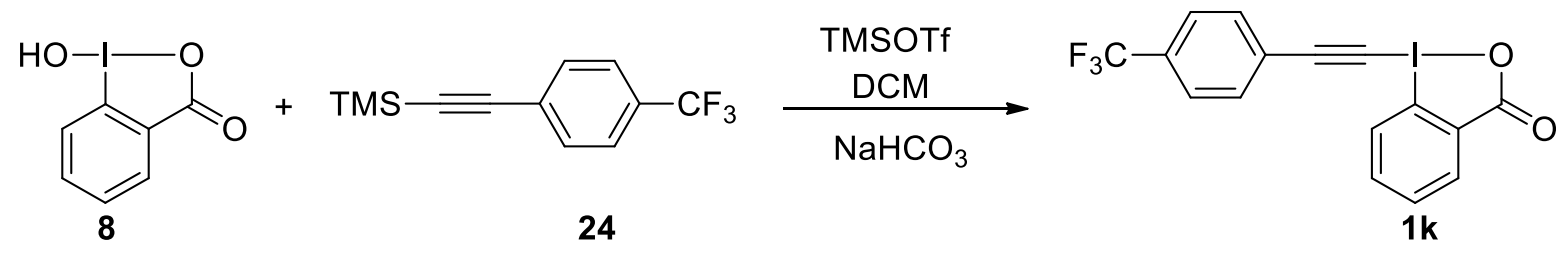

Following a reported procedure ${ }^{[11]}$ trimethylsilyl triflate $(0.80 \mathrm{~mL}, 4.4 \mathrm{mmol}, 1.1$ equiv) was added to a suspension of 2-iodosylbenzoic acid (8) (1.06 g, $4.00 \mathrm{mmol}, 1$ equiv) in $\mathrm{CH}_{2} \mathrm{Cl}_{2}$ (15 $\mathrm{mL}$ ) at RT. The resulting yellow mixture was stirred for $1 \mathrm{~h}$, followed by the dropwise addition of trimethyl((4-(trifluoromethyl)phenyl)ethynyl)silane (24) (1.07 g, $4.40 \mathrm{mmol}, 1.1$ equiv). The resulting suspension was stirred for $6 \mathrm{~h}$ at RT. A saturated solution of $\mathrm{NaHCO}_{3}$ $(20 \mathrm{~mL})$ was then added and the mixture was stirred vigorously for 30 minutes, the two layers were separated and the organic layer was washed with sat. $\mathrm{NaHCO}_{3}(20 \mathrm{~mL})$, dried over $\mathrm{MgSO}_{4}$, filtered and evaporated under reduced pressure. The resulting solid was recrystallized in $\mathrm{CH}_{3} \mathrm{CN}$ (ca $20 \mathrm{~mL}$ ) to afford $\mathbf{1 k}(850 \mathrm{mg}, 2.04 \mathrm{mmol}, 51 \%$ ) as a pale yellow solid.

${ }^{1} \mathrm{H}$ NMR (400 MHz, $\left.\mathrm{CDCl}_{3}\right) \delta 8.46-8.38(\mathrm{~m}, 1 \mathrm{H}, \mathrm{ArH}), 8.28-8.19(\mathrm{~m}, 1 \mathrm{H}, \mathrm{ArH}), 7.84$ - $7.74(\mathrm{~m}, 2 \mathrm{H}, \mathrm{ArH}), 7.74-7.65$ (m, $4 \mathrm{H}, \mathrm{ArH}) .{ }^{13} \mathrm{C} \mathrm{NMR}\left(101 \mathrm{MHz}, \mathrm{CDCl}_{3}\right) \delta$ 166.6, 135.0,

[14] H. Huang, G. Zhang, L. Gong, S. Zhang, Y. Chen, J. Am. Chem. Soc. 2014, 136, 2280.

[15] a) I. F. Dempsey Hyatt, D. J. Nasrallah, M. A. Maxwell, A. C. F. Hairston, M. M. Abdalhameed, M. P. Croatt, Chem. Commun. 2015, 51, 5287; b) O. Dumele, D. Wu, N. Trapp, N. Goroff, F. Diederich, Org. Lett. 2014, 16, 4722 . 
$133.0,132.6,132.2\left(\mathrm{q}, J_{\mathrm{C}-\mathrm{F}}=33.0 \mathrm{~Hz}\right), 131.7,131.2,126.3,125.7\left(\mathrm{q}, J_{\mathrm{C}-\mathrm{F}}=3.6 \mathrm{~Hz}\right), 124.4$, $123.4\left(\mathrm{q}, J_{\mathrm{C}-\mathrm{F}}=272.6 \mathrm{~Hz}\right), 116.1,104.2,53.7$; Consistent with reported data. ${ }^{[16]}$

\section{1-[4-Bromophenylethynyl]-1,2-benziodoxol-3(1H)-one (11)}<smiles>O=C1OI(O)c2ccccc21</smiles>

8

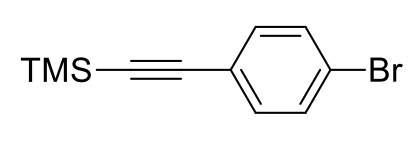

25

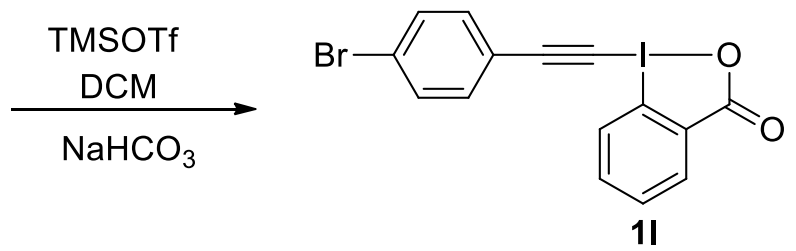

Following a reported procedure ${ }^{[11]}$ trimethylsilyl triflate $(1.0 \mathrm{~mL}, 5.5 \mathrm{mmol}, 1.1$ equiv) was added to a suspension of 2-iodosylbenzoic acid (8) $(1.32 \mathrm{~g}, 5.00 \mathrm{mmol}, 1$ equiv) in $\mathrm{CH}_{2} \mathrm{Cl}_{2}(15 \mathrm{~mL})$ at $\mathrm{RT}$. The resulting suspension was stirred for $3 \mathrm{~h}$, followed by the drop wise addition of ((4-bromophenyl)ethynyl)trimethylsilane (25) (1.17 g, $5.50 \mathrm{mmol}, 1.1$ equiv), which was dissolved in $\mathrm{CH}_{2} \mathrm{Cl}_{2}(1 \mathrm{~mL})$. The resulting suspension was stirred for $6 \mathrm{~h}$ at $\mathrm{RT}$. A saturated solution of $\mathrm{NaHCO}_{3}(20 \mathrm{~mL})$ was then added and the mixture was stirred vigorously for 30 minutes, the two layers were separated and the organic layer was washed with sat. $\mathrm{NaHCO}_{3}(20 \mathrm{~mL})$, dried over $\mathrm{MgSO}_{4}$, filtered and evaporated under reduced pressure. The resulting solid was boiled in $\mathrm{CH}_{3} \mathrm{CN}(20 \mathrm{~mL})$. The mixture was cooled down, filtered and dried under high vacuum to afford 11 (1.00 g, $2.34 \mathrm{mmol}, 47 \%)$ as a pale yellow solid.

Mp 158-163 ${ }^{\circ} \mathrm{C}$ (decomposition). ${ }^{1} \mathrm{H}$ NMR (400 MHz, $\left.\mathrm{CDCl}_{3}\right) \delta 8.51-8.30(\mathrm{~m}, 1 \mathrm{H}$, $\operatorname{Ar} H), 8.30-8.13(\mathrm{~m}, 1 \mathrm{H}, \operatorname{Ar} H$ ), $7.84-7.72(\mathrm{~m}, 2 \mathrm{H}, \operatorname{Ar} H), 7.58(\mathrm{~d}, 2 \mathrm{H}, J=8.5 \mathrm{~Hz}, \operatorname{Ar} H)$, $7.46(\mathrm{~d}, 2 \mathrm{H}, J=8.5 \mathrm{~Hz}, \operatorname{Ar} H) .{ }^{13} \mathrm{C}$ NMR $\left(101 \mathrm{MHz}, \mathrm{CDCl}_{3}\right) \delta 166.6,135.1,134.3,132.7$, 132.3, 131.9, 131.4, 126.3, 125.7, 119.6, 116.3, 105.4, 52.1. IR v 2155 (w), $1612(\mathrm{~s}), 1559(\mathrm{w})$, 1479 (w), 1445 (w), 1328 (m), 1297 (w), 1007 (w), 906 (w). HRMS (ESI) $\mathrm{C}_{15} \mathrm{H}_{9} \mathrm{BrIO}_{2}{ }^{+}[\mathrm{M}+\mathrm{H}]^{+}$calc. $=426.8825 ;[\mathrm{M}+\mathrm{H}]^{+}$obs. $=426.8830$.

\section{1-[2-Bromophenylethynyl]-1,2-benziodoxol-3(1H)-one (1m)}<smiles>O=C1OI(O)c2ccccc21</smiles><smiles>CSC#Cc1ccccc1Br</smiles>

28

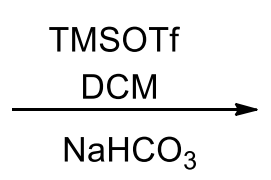

$\mathrm{NaHCO}_{3}$

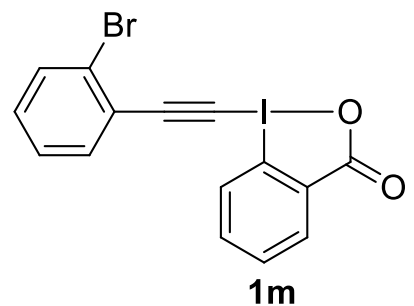

Following a reported procedure ${ }^{[11]}$ trimethylsilyl triflate $(1.0 \mathrm{~mL}, 5.5 \mathrm{mmol}, 1.1$ equiv) was added to a suspension of 2-iodosylbenzoic acid (8) (1.32 g, $5.00 \mathrm{mmol}, 1$ equiv) in $\mathrm{CH}_{2} \mathrm{Cl}_{2}(15 \mathrm{~mL})$ at RT. The resulting suspension was stirred for $3 \mathrm{~h}$, followed by the drop wise addition of ((2-bromophenyl)ethynyl)trimethylsilane (28) (1.17 g, $5.50 \mathrm{mmol}, 1.1$ equiv). The resulting suspension was stirred for $6 \mathrm{~h}$ at RT. A saturated solution of $\mathrm{NaHCO}_{3}(20 \mathrm{~mL})$ was then added and the mixture was stirred vigorously for 30 minutes, the two layers were

[16] B. Lu, J. Wu, N. Yoshikai, J. Am. Chem. Soc. 2014, 136, 11598. 
separated and the organic layer was washed with sat. $\mathrm{NaHCO}_{3}(20 \mathrm{~mL})$, dried over $\mathrm{MgSO}_{4}$, filtered and evaporated under reduced pressure. The resulting solid was boiled in $\mathrm{CH}_{3} \mathrm{CN}$ (20 $\mathrm{mL})$. The mixture was cooled down, filtered and dried under high vacuum to afford $\mathbf{1 m}(1.50$ $\mathrm{g}, 3.51 \mathrm{mmol}, 70 \%)$ as a colorless solid.

Mp 174-177 ${ }^{\circ} \mathrm{C}$ (decomposition). ${ }^{1} \mathrm{H}$ NMR (400 MHz, $\left.\mathrm{CDCl}_{3}\right) \delta 8.44$ (td, $2 \mathrm{H}, J=7.3,2.1$ $\mathrm{Hz}, \operatorname{Ar} H), 7.84-7.74(\mathrm{~m}, 2 \mathrm{H}, \operatorname{Ar} H), 7.68(\mathrm{~d}, 1 \mathrm{H}, J=1.1 \mathrm{~Hz}, \operatorname{Ar} H), 7.61(\mathrm{dd}, 1 \mathrm{H}, J=7.6$, $1.7 \mathrm{~Hz}, \mathrm{Ar} H), 7.36(\mathrm{dtd}, 2 \mathrm{H}, J=22.4,7.5,1.5 \mathrm{~Hz}, \mathrm{Ar} H) .{ }^{13} \mathrm{C} \mathrm{NMR}\left(101 \mathrm{MHz}, \mathrm{CDCl}_{3}\right)^{[17]} \delta$ 166.6, 135.2, 134.7, 133.0, 132.7 , 131.8, 131.3, 127.6, 126.8, 126.4, 123.2, 116.5, 104.3, 55.4. IR $v 2358(\mathrm{w}), 2155(\mathrm{w}), 1638(\mathrm{~s}), 1616(\mathrm{~m}), 1585(\mathrm{w}), 1466$ (w), $1316(\mathrm{~m}), 1147$ (w). HRMS (ESI) $\mathrm{C}_{15} \mathrm{H}_{9} \mathrm{BrIO}_{2}{ }^{+}[\mathrm{M}+\mathrm{H}]^{+}$calc. $=426.8825 ;[\mathrm{M}+\mathrm{H}]^{+}$obs. $=426.8828$.

\section{3,3-Dimethylbutynyl-1,2-benziodoxol-3(1H)-one (1n)}

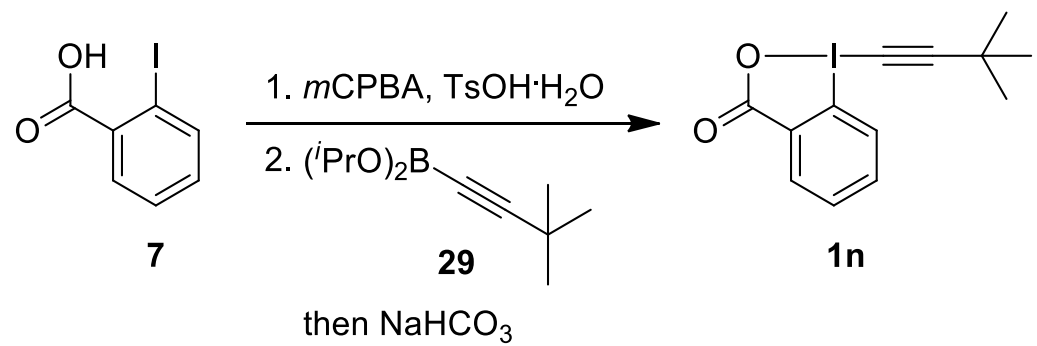

Following a slightly modified procedure, ${ }^{18}$ 2-iodobenzoic acid (7) (1.64 g, $6.59 \mathrm{mmol}$, 1.00 eq.), para-toluenesulfonic acid monohydrate ( $\mathrm{TsOH} \cdot \mathrm{H}_{2} \mathrm{O}, 1.25 \mathrm{~g}, 6.59 \mathrm{mmol}, 1.00$ eq.) and meta-chloroperoxybenzoic acid (mCPBA-70\%, $1.79 \mathrm{~g}, 7.25 \mathrm{mmol}, 1.10 \mathrm{eq}$.) were dissolved in dichloromethane $(12 \mathrm{~mL})$ and 2,2,2-trifluoroethanol $(12 \mathrm{~mL})$. The mixture was stirred at room temperature under nitrogen for 1 hour, after which diisopropyl $(3,3-$ dimethylbut-1-yn-1-yl)boronate (29, $1.94 \mathrm{~g}, 9.23 \mathrm{mmol}, 1.40 \mathrm{eq}$.) was added in one portion. The reaction mixture was stirred for 1 hour at room temperature, filtered and concentrated in vacuo. The resulting oil was dissolved in dichloromethane $(120 \mathrm{~mL})$ and under vigorous stirring, saturated aq. $\mathrm{NaHCO}_{3}(120 \mathrm{~mL})$ was added. The mixture was stirred for 60 minutes, the two layers were separated and the aqueous layer was extracted with additional portions of dichloromethane $\left(3 \times 50 \mathrm{~mL}\right.$ ). The combined organic layers were dried over $\mathrm{MgSO}_{4}$, filtered and concentrated in vacuo. The crude product was purified by flash column chromatography (ethyl acetate) to afford $1 \mathrm{n}(2.06 \mathrm{~g}, 6.28 \mathrm{mmol}, 95 \%)$ as a white solid.

$\mathrm{R}_{f}($ EtOAc $)=0.36 . \mathrm{Mp} 189-192{ }^{\circ} \mathrm{C} .{ }^{1} \mathrm{H}$ NMR $\left(\mathrm{CDCl}_{3}, 400 \mathrm{MHz}\right): \delta 8.39-8.33(\mathrm{~m}, 1 \mathrm{H}$, $\mathrm{Ar} H), 8.13-8.07(\mathrm{~m}, 1 \mathrm{H}, \mathrm{ArH}), 7.78-7.66(\mathrm{~m}, 2 \mathrm{H}, \mathrm{Ar} H), 1.34(\mathrm{~s}, 9 \mathrm{H}, t \mathrm{Bu}) .{ }^{13} \mathrm{C} \mathrm{NMR}\left(\mathrm{CDCl}_{3}\right.$, $100 \mathrm{MHz}): \delta 166.7,134.7,132.4,131.6,131.5,126.0,117.5,115.7,38.2,30.6,29.7$. IR $v$ $3463(\mathrm{w}), 2971(\mathrm{w}), 2171(\mathrm{w}), 1646$ (s), $1622(\mathrm{~s}), 1440(\mathrm{w}), 1332(\mathrm{~m}), 1248(\mathrm{~m}), 913(\mathrm{w}), 832$ (m), 745 (s). HRMS (ESI) $\mathrm{C}_{13} \mathrm{H}_{14} \mathrm{IO}_{2}{ }^{+}[\mathrm{M}+\mathrm{H}]^{+}$calc. $=329.0033 ;[\mathrm{M}+\mathrm{H}]^{+}$obs. $=329.0023$.

\section{Hexadecynyl-1,2-benziodoxol-3(1H)-one (10)}

[17] One carbon is not resolved.

[18] M. J. Bouma, B. Olofsson, Chem. Eur. J. 2012, 18, 14242. 


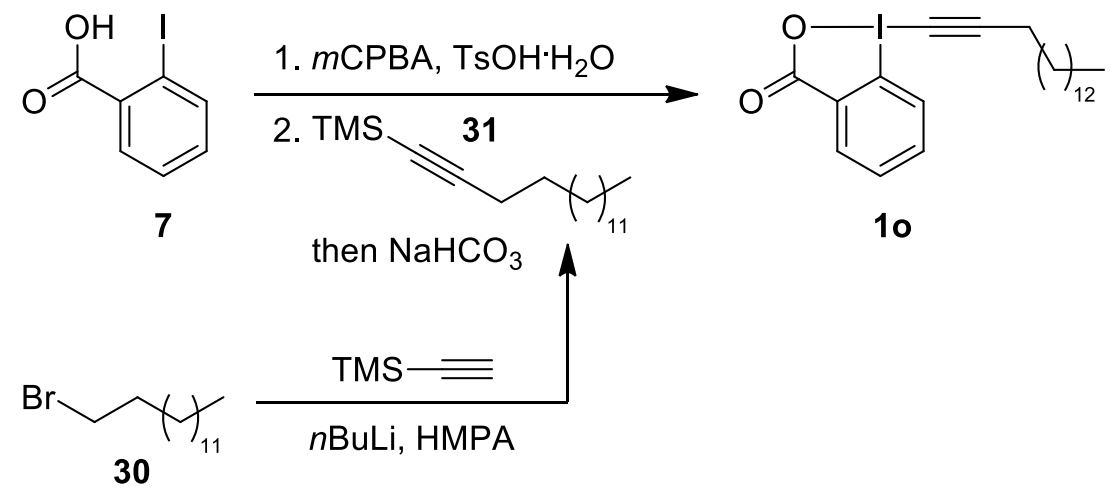

Following a reported procedure, ${ }^{[19]}$ To a mixture of trimethylsilylacetylene $(8.33 \mathrm{~g}, 85.0$ mmol, 1.20 eq.) and dry THF (46 mL) was added at $-78{ }^{\circ} \mathrm{C}$ under nitrogen $2.5 \mathrm{M} n \mathrm{BuLi}$ in hexanes (33.9 mL, $85.0 \mathrm{mmol}, 1.20$ eq.) over a 10 minute time period. The resulting light yellow solution was stirred at $-78{ }^{\circ} \mathrm{C}$ for 60 minutes, after which a mixture consisting of 1bromotetradecane 30 (19.6 g, $70.7 \mathrm{mmol}, 1.00 \mathrm{eq}$.), hexamethylphosphoramide (HMPA, 14.2 $\mathrm{mL}, 78.0 \mathrm{mmol}, 1.10$ eq.) and dry THF (23 mL) was slowly added via cannula over a 20 minute time period. The reaction mixture was stirred for 60 minutes at $-78{ }^{\circ} \mathrm{C}$, followed by 24 hours of stirring at room temperature. The reaction was quenched at $0{ }^{\circ} \mathrm{C}$ with saturated aq. $\mathrm{NH}_{4} \mathrm{Cl}(50 \mathrm{~mL})$ and diluted with water $(10 \mathrm{~mL})$ and EtOAc $(50 \mathrm{~mL})$. The two layers were separated and the aq. layer was extracted with additional portions of EtOAc $(3 \mathrm{x} 50 \mathrm{~mL})$. The combined organic layers were washed with water $(2 \times 100 \mathrm{~mL})$, brine $(100 \mathrm{~mL})$, dried over $\mathrm{MgSO}_{4}$, filtered and concentrated in vacuo. The light brown crude liquid was finally pushed through a small plug of silica gel with pentane as eluent to afford pure hexadec-1-yn-1yltrimethylsilane $\left(\mathbf{3 1}, 19.3 \mathrm{~g}, 65.5 \mathrm{mmol}, 92.7 \%\right.$ yield) as a colorless liquid. $\mathrm{R}_{f}$ (pentane) = 0.78 .

${ }^{1} \mathrm{H} \mathrm{NMR}\left(\mathrm{CDCl}_{3}, 400 \mathrm{MHz}\right): \delta 2.19\left(\mathrm{t}, 2 \mathrm{H}, J=7.1 \mathrm{~Hz}, \mathrm{CCCH}_{2}\right), 1.54-1.44\left(\mathrm{~m}, 2 \mathrm{H}, \mathrm{CH}_{2}\right)$, 1.42-1.18 (m, $22 \mathrm{H}, \mathrm{CH}_{2}$ ), 0.87 (t, $\left.3 \mathrm{H}, J=6.7 \mathrm{~Hz}, \mathrm{CH}_{2} \mathrm{CH}_{3}\right), 0.13$ (s, $\left.9 \mathrm{H}, \mathrm{TMS}\right) .{ }^{13} \mathrm{C}$ NMR $\left(\mathrm{CDCl}_{3}, 100 \mathrm{MHz}\right){ }^{[20]} \delta 107.7,84.3,32.2,29.9,29.8,29.7,29.6,29.3,29.0,28.9,22.9,20.0$, 14.3, 0.3. IR v $2924(\mathrm{~m}), 2854(\mathrm{~m}), 2175(\mathrm{w}), 1461(\mathrm{w}), 1249(\mathrm{w}), 910(\mathrm{w}), 841(\mathrm{~s}), 761(\mathrm{w})$, $736(\mathrm{~m})$. HRMS (ESI) $\mathrm{C}_{19} \mathrm{H}_{38} \mathrm{AgSi}^{+}[\mathrm{M}+\mathrm{Ag}]^{+}$calc. $=401.1794 ;[\mathrm{M}+\mathrm{Ag}]^{+}$obs. $=401.1798$.

2-Iodobenzoic acid (7) (8.00 g, $32.2 \mathrm{mmol}, 1.00$ eq.), para-toluenesulfonic acid monohydrate ( $\mathrm{TsOH} \cdot \mathrm{H}_{2} \mathrm{O}, 6.13 \mathrm{~g}, 32.2 \mathrm{mmol}, 1.00$ eq.) and meta-chloroperoxybenzoic acid ( $m$ CPBA-70\%, $8.74 \mathrm{~g}, 35.5 \mathrm{mmol}, 1.10$ eq.) were dissolved in dichloromethane (60 $\mathrm{mL}$ ) and 2,2,2-trifluoroethanol $(60 \mathrm{~mL})$. The mixture was stirred at room temperature under nitrogen for 1 hour, after which hexadec-1-yn-1-yltrimethylsilane (31, $13.3 \mathrm{~g}, 45.1 \mathrm{mmol}, 1.40$ eq.) was added in one portion. The reaction mixture was stirred for 14 hours at room temperature, filtered and concentrated in vасио. The resulting oil was dissolved in dichloromethane (400 $\mathrm{mL})$ and under vigorous stirring, saturated aq. $\mathrm{NaHCO}_{3}(400 \mathrm{~mL})$ was added. The mixture was stirred for 60 minutes, the two layers were separated and the aqueous layer was extracted

[19] R. Frei, M. D. Wodrich, D. P. Hari, P. A. Borin, C. Chauvier, J. Waser, J. Am. Chem. Soc. 2014, 136, 16563. [20] Some signals were not resolved at $100 \mathrm{MHz}$. 
with additional portions of dichloromethane $(3 \times 100 \mathrm{~mL})$. The combined organic layers were dried over $\mathrm{MgSO}_{4}$, filtered and concentrated in vacuo. The crude product was purified by flash column chromatography (ethyl acetate) to afford 10 (6.02 g, $12.9 \mathrm{mmol}, 40 \%)$ as a white solid.

$\mathrm{R}_{f}(\mathrm{EtOAc})=0.36 . \mathrm{Mp} 102.6-105.3{ }^{\circ} \mathrm{C} .{ }^{1} \mathrm{H} \mathrm{NMR}\left(\mathrm{CDCl}_{3}, 400 \mathrm{MHz}\right): \delta 8.44-8.37(\mathrm{~m}, 1 \mathrm{H}$, $\operatorname{ArH})$, 8.21-8.14 (m, $1 \mathrm{H}, \operatorname{Ar} H), 7.80-7.70(\mathrm{~m}, 2 \mathrm{H}, \mathrm{ArH}), 2.59$ (t, $\left.2 \mathrm{H}, J=7.1 \mathrm{~Hz}, \mathrm{CCCH}_{2}\right)$, $1.65\left(\mathrm{p}, 2 \mathrm{H}, J=7.1 \mathrm{~Hz}, \mathrm{CCCH}_{2} \mathrm{CH}_{2}\right), 1.52-1.40(\mathrm{~m}, 2 \mathrm{H}), 1.39-1.19\left(\mathrm{~m}, 20 \mathrm{H}, \mathrm{CH}_{2}\right), 0.86$ (t, $\left.3 \mathrm{H}, J=6.7 \mathrm{~Hz}, \mathrm{CH}_{2} \mathrm{CH}_{3}\right) .{ }^{13} \mathrm{C} \mathrm{NMR}\left(\mathrm{CDCl}_{3}, 100 \mathrm{MHz}\right): \delta 166.6,134.7,132.5,131.7,131.6$, 126.2, 115.7, 109.9, 39.5, 32.1, 29.8, 29.7, 29.6, 29.5, 29.2, 29.1, 28.3, 22.8, 20.6, 14.3. IR v 2924 (s), 2853 (m), 2166 (w), 1649 (m), 1623 (m), 1439 (w), 908 (m), 736 (s).

\section{Iridium catalyst $(3 b)$}<smiles></smiles>

Following a reported procedure, ${ }^{[21]}$ heteroleptic iridium $\mathbf{3 b}$ was synthesized in two steps. First, the corresponding chloro-bridged dimer was synthesized by charging a two-necked reaction flask with magnetic stirring bar, iridium(III) chloride (366 mg, $1.16 \mathrm{mmol}, 1$ equiv), 2-(2,4difluorophenyl)pyridine $(0.50 \mathrm{~g}, 2.6 \mathrm{mmol}, 2.3 \mathrm{equiv})$, and a $2: 1 \mathrm{v}: \mathrm{v}$ mixture of 2 methoxyethanol $(11 \mathrm{~mL})$ /water $(5.5 \mathrm{~mL})$. After degassing the mixture with $\mathrm{N}_{2}$ (via $\mathrm{N}_{2}$ bubbling), the resulting solution was heated overnight under reflux at $120{ }^{\circ} \mathrm{C}$. Then the reaction mixture was cooled to room temperature and filtered. The yellow precipitate was washed with water $(3 \times 10 \mathrm{~mL})$, dried and directly used for the next step without further purification (620 $\mathrm{mg}$ of yellow powder, $0.510 \mathrm{mmol}, 88 \%$ yield). In the second step, the chloro-bridged dimer (50 mg, $0.041 \mathrm{mmol}, 1.0$ equiv), 4,4'-ditertbutyl bipyridyl ligand (24 mg, $0.090 \mathrm{mmol}, 2.2$ equiv) and ethylene glycol $(2.0 \mathrm{~mL})$ were placed in a flame dried flask and then flushed with $\mathrm{N}_{2}$. The mixture was heated at $150{ }^{\circ} \mathrm{C}$ for $7 \mathrm{~h}$ and then cooled before being washed with pentane $(3 \times 10 \mathrm{~mL})$. Evaporation of pentane residues under vaccuo afforded a crude solution of catalyst in ethylene glycol. Addition of aqueous ammonium hexafluorophosphate (sat. solution) allowed the precipitation of the iridium- $\mathrm{PF}_{6}$ salt, which was filtered, washed with diethylether, dried and recrystallized (acetone / ether) yielding the photocatalyst $\mathbf{3 b}$ as a yellow solid $(70 \mathrm{mg} .0 .071 \mathrm{mmol}, 86 \%) . \mathrm{R}_{f}$ (pentane) $=0.78$. NMR matches the literature data. ${ }^{[21]}$

[21]A. Singh, K. Teegardin, M. Kelly, K. S. Prasad, S. Krishnan, J. D. Weaver, J. Organomet. Chem. 2015, 776, 51. 


\section{Decarboxylative alkynylation}

\section{Optimization of the reaction:}

Dry degassed DCE $(0.5 \mathrm{~mL})$ was added in a flame dried $1.5 \mathrm{~mL}$ test tube containing a teflon coated stirring bar, the carboxylic acid 2 ( $0.10 \mathrm{mmol}, 1.0$ equiv), EBX reagent 1 ( $0.15 \mathrm{mmol}$,

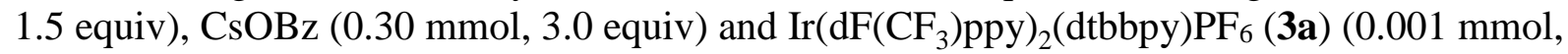
0.01 equiv) under $\mathrm{N}_{2}$. The reaction mixture was again degassed by bubbling $\mathrm{N}_{2}$ inside the test tube via syringe for $5 \mathrm{~min}$ before being irradiated using blue light LEDs for $22 \mathrm{~h}$ at rt.

The reaction mixture was filtered over celite, eluting with ethyl acetate, and evaporated under reduced pressure. The crude product was purified by preparative TLC (Heptane/Ethyl Acetate 8/2) directly without any further work-up.

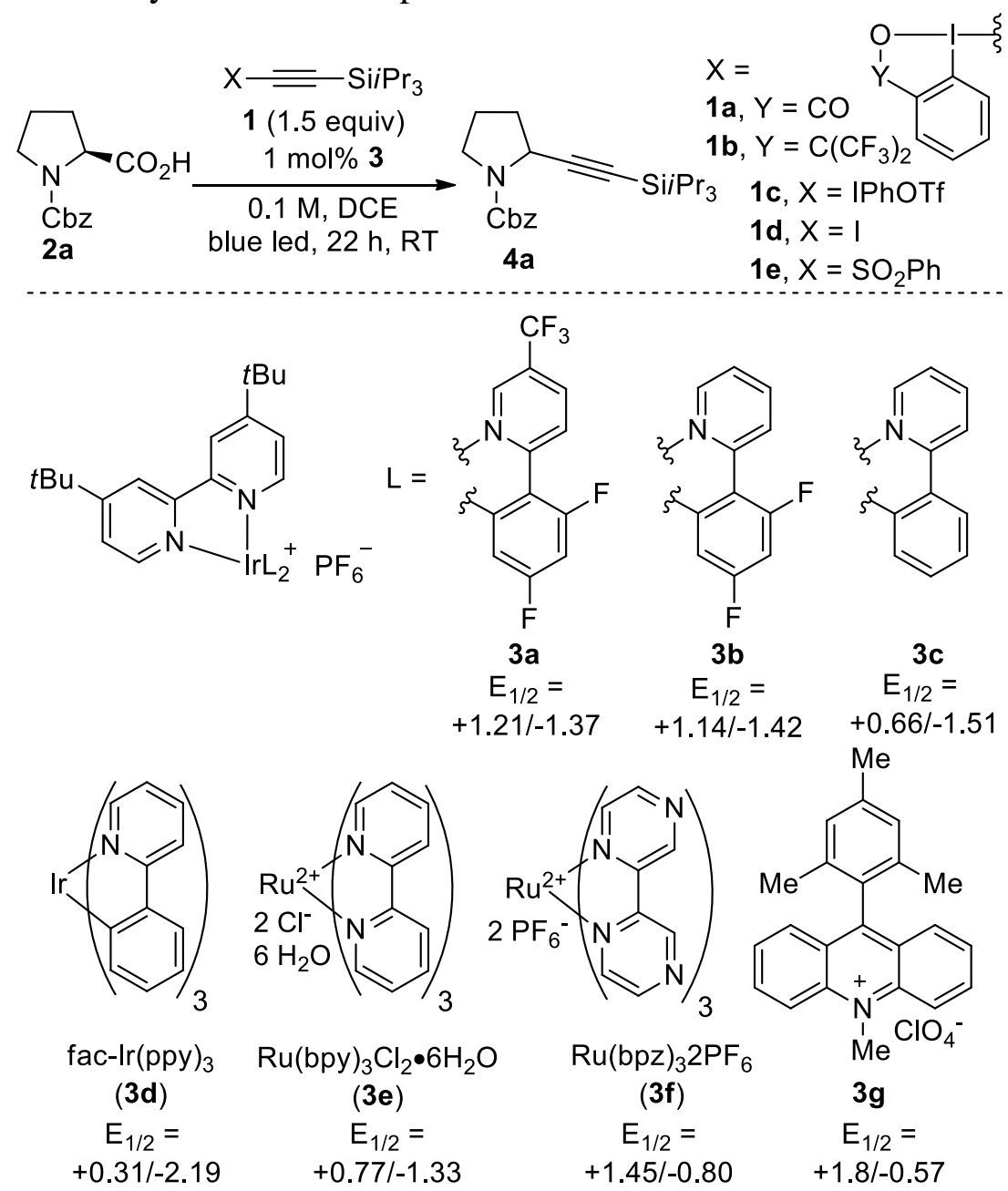

\begin{tabular}{ccccccc}
\hline entry & catalyst & base & reagent & solvent & conversion $^{[a]}$ & yield $^{[b]}$ \\
\hline 1 & 3a & 1.1 equiv CsOAc & $\mathbf{1 a}$ & MeCN & NR & NR \\
2 & 3a & 1.1 equiv CsOAc & $\mathbf{1 a}$ & Toluene & - & $28 \%$ \\
3 & 3a & 1.1 equiv CsOAc & $\mathbf{1 a}$ & THF & - & $33 \%$ \\
4 & 3a & 1.1 equiv CsOAc & $\mathbf{1 a}$ & Water & $\mathrm{NR}$ & $\mathrm{NR}$ \\
5 & 3a & 1.1 equiv CsOAc & $\mathbf{1 a}$ & DMF & - & $20 \%$
\end{tabular}




\begin{tabular}{|c|c|c|c|c|c|c|}
\hline 6 & $3 a$ & 1.1 equiv $\mathrm{CsOAc}$ & $1 \mathrm{a}$ & DMA & - & $20 \%$ \\
\hline 7 & $3 a$ & 1.1 equiv $\mathrm{CsOAc}$ & $1 a$ & DMSO & - & $20 \%$ \\
\hline 8 & $3 a$ & 1.1 equiv $\mathrm{CsOAc}$ & $1 \mathrm{a}$ & DCE / DCM $[$ [c] & - & $31 \%$ \\
\hline 9 & $3 a$ & 2.0 equiv $\mathrm{CsOAc}$ & $1 \mathrm{a}$ & DCE & 90 & $40 \%$ \\
\hline 10 & $3 a$ & 3.0 equiv $\mathrm{CsOAc}$ & $1 \mathrm{a}$ & DCE & 90 & $47 \%$ \\
\hline 11 & $3 a$ & 4.0 equiv $\mathrm{CsOAc}$ & $1 \mathrm{a}$ & DCE & $>95 \%$ & $68 \%$ \\
\hline 12 & $3 a$ & 4.0 equiv KOAc & $1 a$ & DCE & $<50 \%$ & $9 \%$ \\
\hline 13 & $3 a$ & 4.0 equiv $\mathrm{NaOAc}$ & $1 a$ & DCE & $<50 \%$ & $22 \%$ \\
\hline 14 & $3 a$ & 4.0 equiv $\mathrm{Cs}_{2} \mathrm{CO}_{3}$ & $1 a$ & DCE & $>95 \%$ & $35 \%$ \\
\hline 15 & $3 a$ & 4.0 equiv $\mathrm{CsO}(4-\mathrm{tBuBz})$ & $1 a$ & DCE & $>95 \%$ & $60 \%$ \\
\hline 16 & $3 a$ & 4.0 equiv $\mathrm{CsOBz}$ & $1 a$ & DCE & $>95 \%$ & $74 \%$ \\
\hline 17 & $3 b$ & 4.0 equiv $\mathrm{CsOBz}$ & $1 a$ & DCE & $>95 \%$ & $68 \%$ \\
\hline 18 & $3 c$ & 4.0 equiv $\mathrm{CsOBz}$ & $1 a$ & DCE & $<10 \%$ & $<5 \%$ \\
\hline 19 & $3 d$ & 4.0 equiv $\mathrm{CsOBz}$ & $1 a$ & DCE & $<10 \%$ & $<5 \%$ \\
\hline 20 & $3 e$ & 4.0 equiv $\mathrm{CsOBz}$ & $1 \mathrm{a}$ & DCE & $<10 \%$ & $<5 \%$ \\
\hline 21 & $3 f$ & 4.0 equiv $\mathrm{CsOBz}$ & $1 a$ & DCE & $<10 \%$ & $<5 \%$ \\
\hline 22 & $3 g$ & 4.0 equiv $\mathrm{CsOBz}$ & $1 a$ & DCE & $<10 \%$ & $<5 \%$ \\
\hline $23^{[d]}$ & $3 a$ & 4.0 equiv $\mathrm{CsOBz}$ & $1 \mathrm{a}$ & DCE & $75 \%$ & $38 \%$ \\
\hline $24^{[e]}$ & $3 a$ & 4.0 equiv $\mathrm{CsOBz}$ & $1 a$ & DCE & $>95 \%$ & $12 \%$ \\
\hline $25^{[f]}$ & $3 a$ & 3.0 equiv $\mathrm{CsOBz}$ & $1 a$ & DCE & $>95 \%$ & $92 \%$ \\
\hline $26^{[f]}$ & $3 a$ & 3.0 equiv $\mathrm{CsOBz}$ & $1 b$ & DCE & $>95 \%$ & $38 \%$ \\
\hline $27^{[f]}$ & $3 a$ & 3.0 equiv $\mathrm{CsOBz}$ & $1 \mathrm{c}$ & DCE & $>95 \%$ & $<5 \%$ \\
\hline $28^{[f]}$ & $3 a$ & 3.0 equiv $\mathrm{CsOBz}$ & 1d & DCE & $>95 \%$ & $82 \%$ \\
\hline $29^{[f]}$ & $3 a$ & 3.0 equiv $\mathrm{CsOBz}$ & $1 e$ & DCE & $>95 \%$ & $<5 \%$ \\
\hline
\end{tabular}

[a] Reaction conditions: Using $0.1 \mathrm{mmol} 2 \mathbf{2 a}$ (1 equiv), $0.15 \mathrm{mmol} \mathbf{1}$ (1.5 equiv), $1 \mu \mathrm{mol} \mathbf{3}$ (0.01 equiv) in DCE (1 $\mathrm{mL}$ ) for $22 \mathrm{~h}$ at RT. The conversion of $\mathbf{2 a}$ by NMR is given. The values for reduction potentials are given in volts for catalyst $\mathbf{3}$ in relation to SCE, except for $\mathbf{3 b}$ which is reported relatively to ferrocene. ${ }^{[b]}$ Isolated yield after preparative TLC. ${ }^{[c]}$ DCE was preferred to avoid evaporation of the solvent during overnight reactions. ${ }^{[\mathrm{d}]}$ Using 1.1 equiv of EBX reagent. ${ }^{[\mathrm{e}]}$ Using 2.0 equiv of EBX reagent. ${ }^{[\mathrm{ff}]} \mathrm{In} 0.5 \mathrm{~mL}$ DCE.

\section{General procedure for decarboxvlative alkynvlation.}

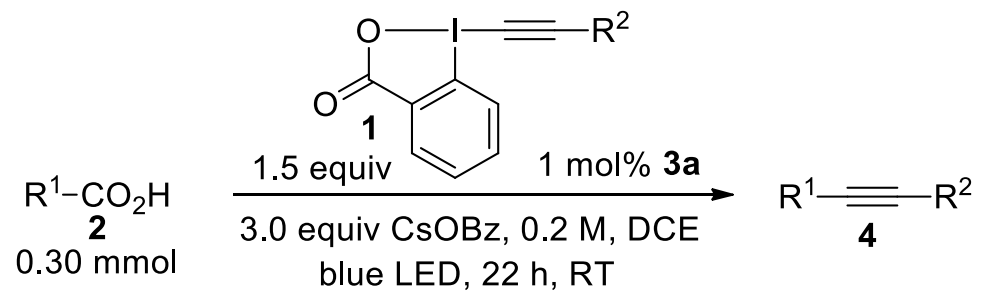


Dry degassed DCE $(1.5 \mathrm{~mL})$ was added in a flame dried $4.0 \mathrm{~mL}$ test tube containing a teflon coated stirring bar, the carboxylic acid 2 ( $0.30 \mathrm{mmol}, 1.0$ equiv), EBX reagent 1 (0.45 mmol,

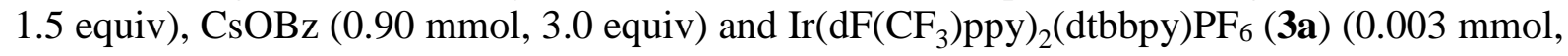
0.01 equiv) under $\mathrm{N}_{2}$. The reaction mixture was again degassed by bubbling $\mathrm{N}_{2}$ inside the test tube via syringe for $5 \mathrm{~min}$ before being irradiated using blue light LEDs for $22 \mathrm{~h}$ at $\mathrm{rt}$.

The reaction mixture was filtered over celite, eluting with ethyl acetate, and evaporated under reduced pressure. The crude product was purified by column chromatography (Pentane/Ethyl Acetate) directly without any further work-up.

\section{Benzyl 2-((triisopropylsilyl)ethynyl)pyrrolidine-1-carboxylate (4a)}

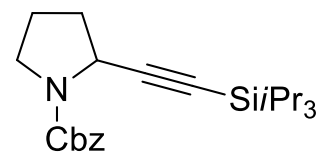

Scope scale: Starting from 2a $(75 \mathrm{mg}, 0.30 \mathrm{mmol})$, the crude product was purified by column chromatography (Pentane/Ethyl Acetate $=9: 1)$ to afford 4a as colorless oil (104 mg, 0.270 mmol, 90\%).

1 mmol scale: Starting from $2 \mathrm{a}(250 \mathrm{mg}, 1.0 \mathrm{mmol})$, the crude product was purified by column chromatography (Pentane/Ethyl Acetate $=9: 1$ ) to afford $\mathbf{4 a}$ as colorless oil $(344 \mathrm{mg}$, $0.892 \mathrm{mmol}, 89 \%)$.

Sunlight experiment: Starting from 2a $(25 \mathrm{mg}, 0.10 \mathrm{mmol})$, the reaction mixture was stirred for $5 \mathrm{~h}$ outdoors, under sunlight exposition instead of blue leds. The crude product was purified by column chromatography (Pentane/Ethyl Acetate $=9: 1$ ) to afford $\mathbf{4 a}$ as colorless oil (34 mg, $0.088 \mathrm{mmol}, 88 \%$ ).

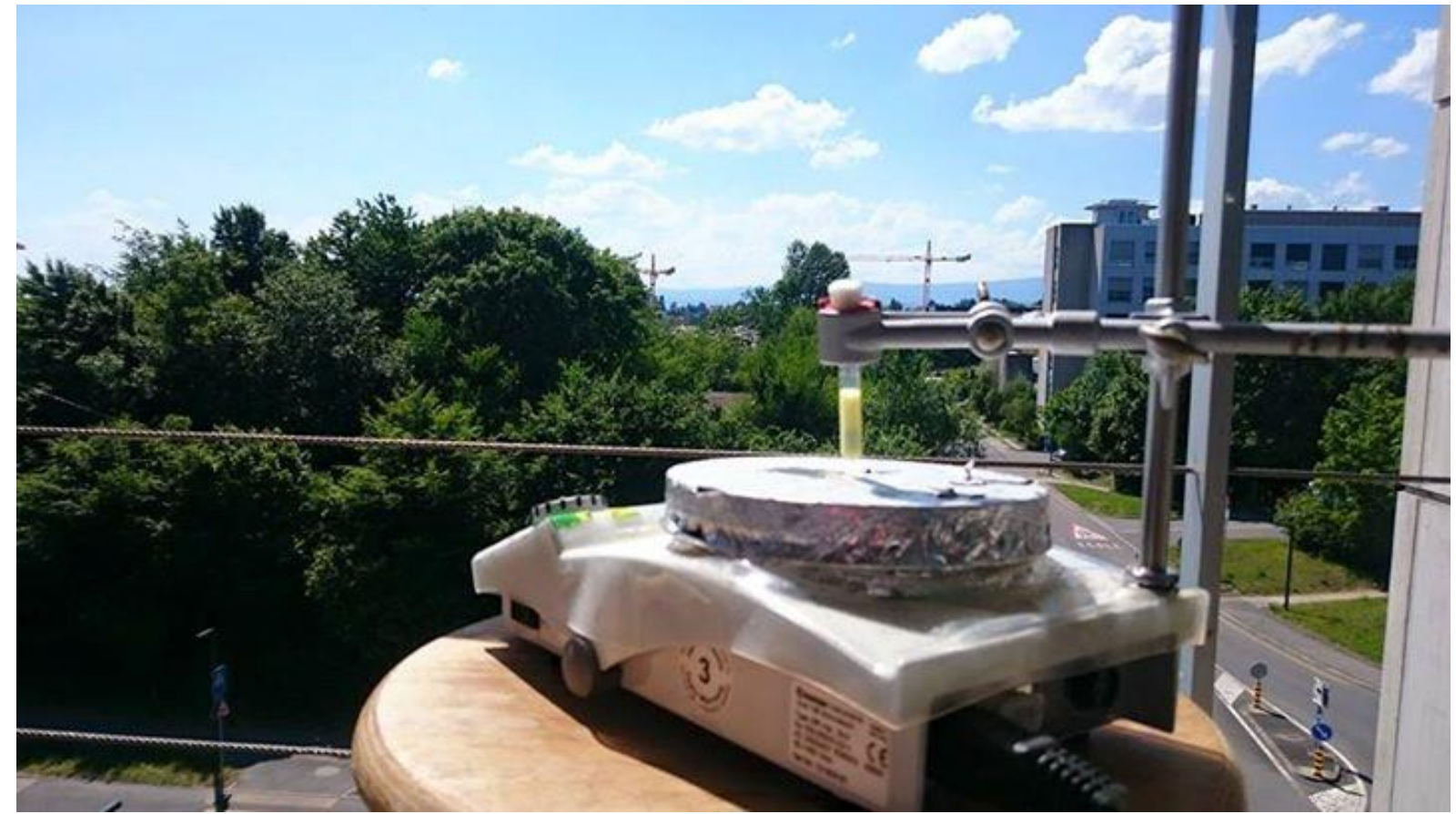

$\mathrm{R}_{\mathrm{f}}: 0.28$ (Pentane/Ethyl Acetate = 9:1). ${ }^{1} \mathrm{H}$ NMR $\left(400 \mathrm{MHz}, \mathrm{CDCl}_{3}\right) \delta 7.46-7.27(\mathrm{~m}, 5 \mathrm{H}, \mathrm{Ph})$, $5.16\left(\mathrm{~d}, J=3.2 \mathrm{~Hz}, 2 \mathrm{H}, \mathrm{CH}_{2}-\mathrm{O}\right), 4.67-4.51(\mathrm{~m}, 1 \mathrm{H}, \mathrm{CH}-\mathrm{C} \equiv \mathrm{C}), 3.64-3.49\left(\mathrm{~m}, 1 \mathrm{H}, \mathrm{CH}_{2}\right)$, 
$3.47-3.30\left(\mathrm{~m}, 1 \mathrm{H}, \mathrm{CH}_{2}\right), 2.21-1.98\left(\mathrm{~m}, 3 \mathrm{H}, \mathrm{CH}_{2}\right), 1.99-1.87\left(\mathrm{~m}, 1 \mathrm{H}, \mathrm{CH}_{2}\right), 1.11-0.93(\mathrm{~m}$, 21H, TIPS). ${ }^{13} \mathrm{C}$ NMR $\left(101 \mathrm{MHz}, \mathrm{CDCl}_{3}\right)^{[22]} \delta 154.6,136.9,128.4,127.8,127.8,127.6,107.9$, 82.6, 66.9, 66.7, 49.3, 48.8, 46.0, 45.5, 34.3, 33.4, 24.4, 23.6, 18.6, 11.1. IR 2943 (m), 2865 (m), $2170(\mathrm{w}), 1709$ (s), 1464 (w), 1410 (s), 1356 (m), $1184(\mathrm{~m}), 1119(\mathrm{~m}), 1092(\mathrm{~m}), 996(\mathrm{w})$, 883 (m). HRMS (ESI) calcd for $\mathrm{C}_{23} \mathrm{H}_{35} \mathrm{NNaO}_{2} \mathrm{Si}^{+}[\mathrm{M}+\mathrm{Na}]^{+} 408.2329$; found 408.2334.

Sun spectra during experiment: ${ }^{[23]}$

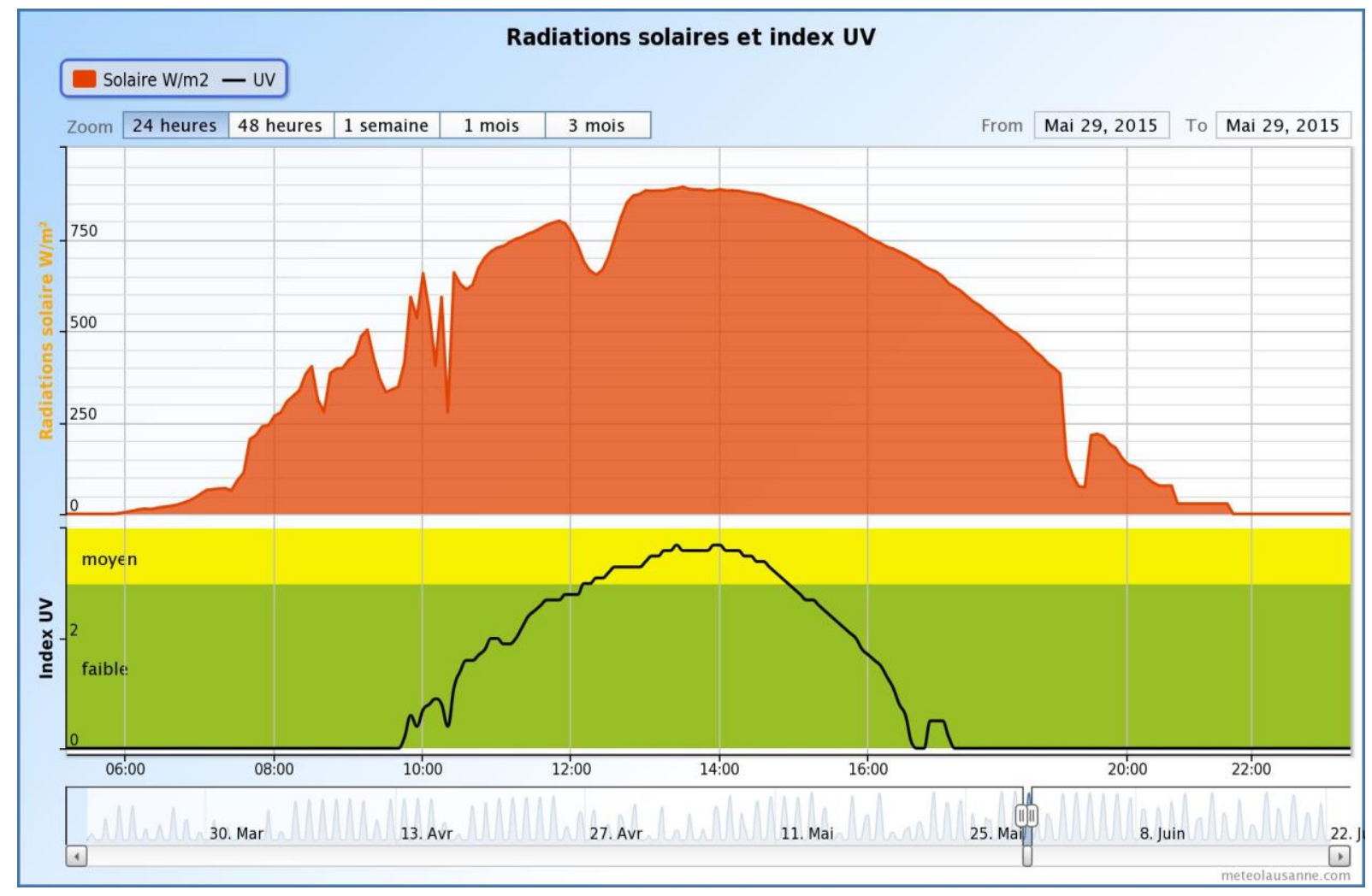

Tert-butyl 2-((triisopropylsilyl)ethynyl)pyrrolidine-1-carboxylate (4b)

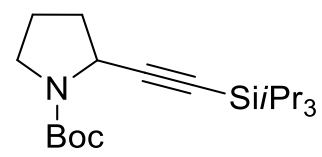

Starting from $\mathbf{2 b}(65 \mathrm{mg}, 0.30 \mathrm{mmol})$, the crude product was purified by column chromatography (Pentane/Ethyl Acetate $=9: 1)$ to afford $\mathbf{4 b}$ as colorless oil $(95 \mathrm{mg}, 0.27$ mmol, 90\%).

Rf: 0.3 (Pentane/Ethyl Acetate = 9:1). ${ }^{1} \mathrm{H}$ NMR $\left(400 \mathrm{MHz}, \mathrm{CDCl}_{3}\right) \delta 4.52-4.35(\mathrm{~m}, 1 \mathrm{H}, \mathrm{CH}-$ $\mathrm{C} \equiv \mathrm{C}), 3.55-3.41\left(\mathrm{~m}, 1 \mathrm{H}, \mathrm{NCH}_{2}\right), 3.36-3.19\left(\mathrm{~m}, 1 \mathrm{H}, \mathrm{NCH}_{2}\right), 2.14-1.94\left(\mathrm{~m}, 3 \mathrm{H}, \mathrm{CH}_{2}\right), 1.94$ $-1.83\left(\mathrm{~m}, 1 \mathrm{H}, \mathrm{CH}_{2}\right), 1.46(\mathrm{~s}, 9 \mathrm{H}, t \mathrm{Bu}), 1.12-0.87(\mathrm{~m}, 21 \mathrm{H}, T I P S) .{ }^{13} \mathrm{C}$ NMR $(101 \mathrm{MHz}$, $\left.\mathrm{CDCl}_{3}\right) \delta 154.1,108.5,81.5,79.5,48.8,45.4,34.2,28.4,23.6,18.6,11.2$. IR $2979(\mathrm{w}), 2974$ (w), $2867(\mathrm{w}), 2173(\mathrm{w}), 1704$ (s), 1392 (s), 1366 (m), 1332 (w), 1255 (w), 1170 (s), 1121 (m), $1092(\mathrm{~m}), 955(\mathrm{w}), 882(\mathrm{w})$. HRMS (ESI) calcd for $\mathrm{C}_{20} \mathrm{H}_{37} \mathrm{NNaO}_{2} \mathrm{Si}^{+}[\mathrm{M}+\mathrm{Na}]^{+}$374.2486; found 374.2483 .

[22] Mixture of two rotamers, which are not completely resolved.

[23] Taken from: http://www.meteolausanne.com/soleil-et-uv.html 
Tert-butyl 2-((triisopropylsilyl)ethynyl)piperidine-1-carboxylate (4c)

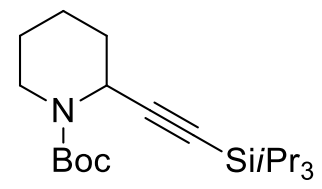

Starting from 2c $(69 \mathrm{mg}, 0.30 \mathrm{mmol})$, the crude product was purified by column chromatography (Pentane/Ethyl Acetate $=9: 1)$ to afford $\mathbf{4 c}$ as colorless oil $(72 \mathrm{mg}, 0.20 \mathrm{mmol}$, $66 \%)$.

$\mathrm{R}_{\mathrm{f}}: 0.45$ (Pentane/Ethyl Acetate = 9:1). ${ }^{1} \mathrm{H}$ NMR $\left(400 \mathrm{MHz}, \mathrm{CDCl}_{3}\right) \delta 5.21-4.90(\mathrm{~m}, 1 \mathrm{H}$, $\mathrm{CH}-\mathrm{C} \equiv \mathrm{C}), 4.01-3.78\left(\mathrm{~m}, 1 \mathrm{H}, \mathrm{CH}_{2}-\mathrm{N}\right), 3.15-2.91\left(\mathrm{~m}, 1 \mathrm{H}, \mathrm{CH}_{2}-\mathrm{N}\right), 1.89-1.70(\mathrm{~m}, 2 \mathrm{H}$, $\left.\mathrm{CH}_{2}\right), 1.71-1.52\left(\mathrm{~m}, 4 \mathrm{H}, \mathrm{CH}_{2}\right), 1.46(\mathrm{~s}, 9 \mathrm{H}, t \mathrm{Bu}), 1.12-0.87(\mathrm{~m}, 21 \mathrm{H}, \mathrm{TIPS}) .{ }^{13} \mathrm{C} \mathrm{NMR}(101$ $\left.\mathrm{MHz}, \mathrm{CDCl}_{3}\right) \delta 154.8,106.1,84.3,79.8,76.7,30.6,28.4,25.3,20.0,18.6,11.4,11.2 . \mathrm{IR} 2941$ (m), $2865(\mathrm{~m}), 2166(\mathrm{w}), 1695(\mathrm{~m}), 1464(\mathrm{w}), 1389(\mathrm{~m}), 1367$ (m), $1318(\mathrm{~m}), 1271(\mathrm{~m}), 1162$ (s), 1007 (m), $924(\mathrm{w}), 884(\mathrm{~m})$. HRMS (ESI) calcd for $\mathrm{C}_{21} \mathrm{H}_{39} \mathrm{NNaO}_{2} \mathrm{Si}^{+}[\mathrm{M}+\mathrm{Na}]^{+}$388.2642; found 388.2639.

\section{Benzyl 3-((triisopropylsilyl)ethynyl)-3,4-dihydroisoquinoline-2(1H)-carboxylate (4d)}<smiles>O=C(OCc1ccccc1)[Hg]C#CC1Cc2ccccc2CN1C(=O)O</smiles>

New compound

Starting from 2d $(93 \mathrm{mg}, 0.30 \mathrm{mmol})$, the crude product was purified by column chromatography (Pentane/Ethyl Acetate $=9: 1)$ to afford 4d as colorless oil (116 mg, 0.260 mmol, 87\%).

$\mathrm{R}_{\mathrm{f}}: 0.30$ (Pentane/Ethyl Acetate = 9:1). ${ }^{1} \mathrm{H}$ NMR $\left(400 \mathrm{MHz}, \mathrm{CDCl}_{3}\right)^{[22]} \delta 7.50-7.30(\mathrm{~m}, 5 \mathrm{H}$, $P h), 7.25-6.99(\mathrm{~m}, 4 \mathrm{H}, A r \mathrm{H}), 5.61-5.29(\mathrm{~m}, 1 \mathrm{H}, \mathrm{CH}-\mathrm{C} \equiv \mathrm{C}), 5.32-5.13\left(\mathrm{~m}, 2 \mathrm{H}, \mathrm{CH}_{2}\right), 4.94$ $\left(\mathrm{d}, J=16.6 \mathrm{~Hz}, 1 \mathrm{H}, \mathrm{CH}_{2}-\mathrm{N}\right), 4.57\left(\mathrm{~d}, J=16.7 \mathrm{~Hz}, 1 \mathrm{H}, C_{2}-\mathrm{N}\right), 3.21(\mathrm{dd}, J=14.9,4.9 \mathrm{~Hz}$, $\left.1 \mathrm{H}, \mathrm{CH}_{2}\right), 3.02-2.78\left(\mathrm{~m}, 1 \mathrm{H}, \mathrm{CH}_{2}\right), 0.97-0.77(\mathrm{~m}, 21 \mathrm{H}, \mathrm{TIPS}) .{ }^{13} \mathrm{C}$ NMR $(101 \mathrm{MHz}$, $\left.\mathrm{CDCl}_{3}\right)^{[22]} \delta 155.0,136.6,132.3,131.9,129.3,129.1,128.5,128.1,127.9,126.4,125.8,105.0$, 84.7, 67.5, 43.3, 35.4, 18.3, 10.9. IR $2943(\mathrm{w}), 2865(\mathrm{w}), 2250(\mathrm{w}), 2171(\mathrm{w}), 1711(\mathrm{w}), 1464$ (w), $1423(\mathrm{w}), 1319(\mathrm{w}), 1301(\mathrm{w}), 1243$ (m), $1219(\mathrm{~m}), 1118(\mathrm{w}), 998(\mathrm{~m}), 909(\mathrm{~s}), 883(\mathrm{~m})$. HRMS (ESI) calcd for $\mathrm{C}_{28} \mathrm{H}_{38} \mathrm{NO}_{2} \mathrm{Si}^{+}[\mathrm{M}+\mathrm{H}]^{+} 448.2666$; found 448.2661 .

\section{Tert-butyl (3-(triisopropylsilyl)prop-2-yn-1-yl)carbamate (4e)}

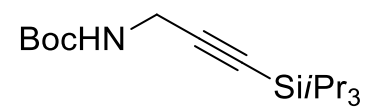

Starting from 2e $(53 \mathrm{mg}, 0.30 \mathrm{mmol})$, the crude product was purified by column chromatography (Pentane/Ethyl Acetate $=9: 1)$ to afford $4 \mathbf{e}$ as colorless oil $(65 \mathrm{mg}, 0.21$ mmol, 70\%).

$\mathrm{R}_{\mathrm{f}}: 0.28$ (Pentane/Ethyl Acetate = 9:1). ${ }^{1} \mathrm{H}$ NMR $\left(400 \mathrm{MHz}, \mathrm{CDCl}_{3}\right) \delta 4.74-4.58(\mathrm{~m}, 1 \mathrm{H}$, $\mathrm{NH}), 4.02-3.85\left(\mathrm{~m}, 2 \mathrm{H}, \mathrm{CH}_{2}\right), 1.44(\mathrm{~s}, 9 \mathrm{H}, t \mathrm{Bu}), 1.15-0.92(\mathrm{~m}, 21 \mathrm{H}, \mathrm{TIPS}) .{ }^{13} \mathrm{C} \mathrm{NMR}(101$ $\left.\mathrm{MHz}, \mathrm{CDCl}_{3}\right) \delta 155.2,103.6,84.1,79.8,31.6,28.3,18.5,11.1$. IR $3332(\mathrm{w}), 2943$ (s), 2860 
(s), $2178(\mathrm{w}), 1704(\mathrm{~s}), 1502(\mathrm{~m}), 1464(\mathrm{~m}), 1367(\mathrm{~m}), 1277(\mathrm{~m}), 1249(\mathrm{~m}), 1170$ (s), 1049 (m), 1017 (s), 1002 (s), 918 (m), 884 (s). HRMS (ESI) calcd for $\mathrm{C}_{17} \mathrm{H}_{33} \mathrm{NNaO}_{2} \mathrm{Si}^{+}[\mathrm{M}+\mathrm{Na}]^{+}$ 334.2173; found 334.2176.

\section{Triisopropyl((tetrahydrofuran-2-yl)ethynyl)silane (4f)}

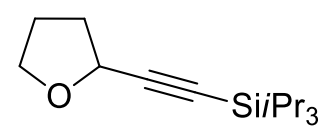

Starting from 2 f $(35 \mathrm{mg}, 0.30 \mathrm{mmol}$ ), the crude product was purified by column chromatography (100\% Pentane) to afford $\mathbf{4 f}$ as colorless oil ( $76 \mathrm{mg}, 0.30 \mathrm{mmol}$, quantitative).

$\mathrm{R}_{\mathrm{f}}: 0.8$ (Pentane). ${ }^{1} \mathrm{H}$ NMR $\left(400 \mathrm{MHz}, \mathrm{CDCl}_{3}\right) \delta 4.60(\mathrm{dd}, J=7.2,4.5 \mathrm{~Hz}, 1 \mathrm{H}, C H-C \equiv C)$, $3.97-3.90(\mathrm{~m}, 1 \mathrm{H}, \mathrm{CH}-\mathrm{O}), 3.83-3.77(\mathrm{~m}, 1 \mathrm{H}, \mathrm{CH}-\mathrm{O}), 2.20-1.80\left(\mathrm{~m}, 4 \mathrm{H}, 2 \times \mathrm{CH}_{2}\right), 1.13-$ $0.96\left(\mathrm{~m}, 21 \mathrm{H}\right.$, TIPS). ${ }^{13} \mathrm{C} \mathrm{NMR}\left(101 \mathrm{MHz}, \mathrm{CDCl}_{3}\right) \delta 107.8,85.0,68.5,67.5,33.7,25.1,18.6$, 11.1. IR 2943 (s), 2866 (s), 2168 (w), 1463 (s), 1329 (m), 1180 (w), 1055 (s), 996 (m), 919 (m), 883 (s).The data correspond to the reported values. ${ }^{[24]}$

Triisopropyl((tetrahydro-2H-pyran-2-yl)ethynyl)silane (4g)

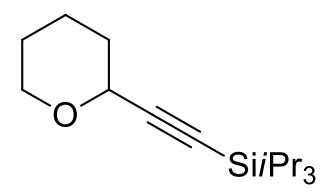

Starting from $2 \mathrm{~g}(39 \mathrm{mg}, 0.30 \mathrm{mmol})$, the crude product was purified by column chromatography (100\% Pentane) to afford $\mathbf{4 g}$ as colorless oil (48 $\mathrm{mg}, 0.18 \mathrm{mmol}, 60 \%)$

$\mathrm{R}_{\mathrm{f}}: 0.85$ (Pentane). $4.40(\mathrm{dd}, J=6.3,3.0 \mathrm{~Hz}, 1 \mathrm{H}, \mathrm{CH}-\mathrm{C} \equiv \mathrm{C}), 4.06-3.97\left(\mathrm{~m}, 1 \mathrm{H}, \mathrm{CH}_{2} \mathrm{O}\right), 3.61$ - $3.50\left(\mathrm{~m}, 1 \mathrm{H}, \mathrm{CH}_{2} \mathrm{O}\right), 1.92-1.80\left(\mathrm{~m}, 2 \mathrm{H}, \mathrm{CH}_{2}\right), 1.75-1.65\left(\mathrm{~m}, 1 \mathrm{H}, \mathrm{CH}_{2}\right), 1.63-1.49(\mathrm{~m}$, $\left.3 \mathrm{H}, \mathrm{CH}_{2}\right), 1.11-0.99(\mathrm{~m}, 21 \mathrm{H}, \mathrm{TIPS}) .{ }^{13} \mathrm{C} \mathrm{NMR}\left(101 \mathrm{MHz}, \mathrm{CDCl}_{3}\right) \delta 106.4,86.2,67.0,65.6$, 32.2, 25.7, 21.1, 18.6, 11.2. IR 2941 (m), $2865(\mathrm{~m}), 1726(\mathrm{w}), 1680(\mathrm{~m}), 1620(\mathrm{~s}), 1556(\mathrm{~m})$, 1464 (m), 1374 (m), 1334 (m), 1294 (w), 1265 (w), 1198 (s), 1158 (m), 1118 (w), 1085 (s), 1040 (s), 1021 (s), 1015 (m), 971 (m), 884 (s), 869 (s). HRMS (ESI) calcd for $\mathrm{C}_{16} \mathrm{H}_{30} \mathrm{NaOSi}^{+}$ $[\mathrm{M}+\mathrm{Na}]^{+}$289.1958; found 289.1960 .

\section{(3-Butoxyprop-1-yn-1-yl)triisopropylsilane (4h)}

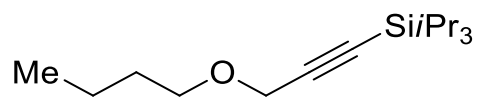

[24] R.-Y. Zhang, L.-Y. Xi, L. Zhang, S. Liang, S.-Y. Chen, X.-Q. Yu, RSC Advances 2014, 4, 54349. 
Starting from $\mathbf{2 h}(39 \mathrm{mg}, 0.30 \mathrm{mmol})$, the crude product was analyzed directly by NMR using Trimethoxybenzene as internal standard. (11 mg, 0.21 equiv), which showed the formation of 4h in $88 \%$ yield (71 mg, $0.26 \mathrm{mmol}, 88 \%$ NMR yield).

$\mathrm{R}_{\mathrm{f}}: 0.85$ (Pentane). ${ }^{1} \mathrm{H}$ NMR $\left(400 \mathrm{MHz}, \mathrm{CDCl}_{3}\right) \delta 4.17\left(\mathrm{~s}, 2 \mathrm{H}, \mathrm{CH}_{2}-\mathrm{C} \equiv \mathrm{C}\right), 3.54(\mathrm{t}, J=6.6 \mathrm{~Hz}$, $\left.2 \mathrm{H}, \mathrm{CH}_{2} \mathrm{O}\right), 1.57\left(\mathrm{dq}, J=8.3,6.7 \mathrm{~Hz}, 2 \mathrm{H}, \mathrm{CH}_{2}\right), 1.39\left(\mathrm{dt}, J=14.8,7.3 \mathrm{~Hz}, 2 \mathrm{H}, \mathrm{CH}_{2}\right), 1.12-$ $1.01(\mathrm{~m}, 21 \mathrm{H}, T I P S), 0.92\left(\mathrm{t}, J=7.4 \mathrm{~Hz}, 3 \mathrm{H}, \mathrm{CH}_{3}\right) .{ }^{13} \mathrm{C} \mathrm{NMR}\left(101 \mathrm{MHz}, \mathrm{CDCl}_{3}\right) \delta 103.8$, 87.1, 69.4, 58.7, 31.6, 19.3, 18.6, 13.9, 11.2. IR 2942 (m), $2865(\mathrm{~m}), 2248(\mathrm{w}), 2170(\mathrm{w})$, $2094(\mathrm{w}), 1733$ (s), 1680 (m), 1623 (m), 1510 (w), 1464 (m), 1437 (m), 1383 (s), 1294 (m), 1206 (m), 1152 (s), 997 (m), 884 (s). HRMS (ESI): calcd for $\mathrm{C}_{16} \mathrm{H}_{32} \mathrm{NaOSi}^{+}[\mathrm{M}+\mathrm{Na}]^{+}$ 291.2120; found 291.2112.

\section{(3-(4-(Tert-butyl)phenoxy)prop-1-yn-1-yl)triisopropylsilane (4i)}

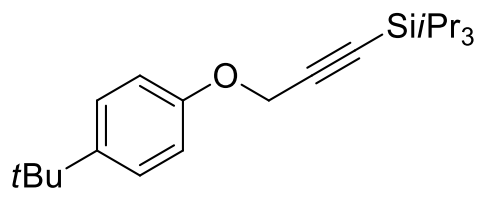

Starting from $2 \mathbf{i}(63 \mathrm{mg}, 0.30 \mathrm{mmol})$, the crude product was purified by column chromatography (Pentane) affording the expected compound $4 \mathbf{i}$ in $84 \%$ yield.

$\mathrm{R}_{\mathrm{f}}: 0.85$ (Pentane). ${ }^{1} \mathrm{H}$ NMR (400 MHz, $\left.\mathrm{CDCl}_{3}\right) \delta 7.32-7.27$ (m, 2H, 2 x ArCH), $6.96-6.90$ $(\mathrm{m}, 2 \mathrm{H}, 2 \times \mathrm{ArCH}), 4.71\left(\mathrm{~s}, 2 \mathrm{H}, \mathrm{CH}_{2}\right), 1.29(\mathrm{~s}, 9 \mathrm{H}, t \mathrm{Bu}), 1.05-1.00\left(\mathrm{~m}, 21 \mathrm{H}\right.$, TIPS). ${ }^{13} \mathrm{C}$ NMR $\left(101 \mathrm{MHz}, \mathrm{CDCl}_{3}\right) \delta{ }^{13} \mathrm{C}$ NMR $\left(101 \mathrm{MHz}, \mathrm{CDCl}_{3}\right) \delta 155.4,144.1,126.0,115.0,102.3$, 100.8, 57.0, 34.1, 31.5, 18.5, 11.1. IR $3064(\mathrm{w}), 2835(\mathrm{w}), 2114(\mathrm{w}), 2081(\mathrm{w}), 1736(\mathrm{w})$, 1622 (s), 1513 (s), 1440 (w), 1296 (w), 1224 (m), 1206 (m), 1205 (m), 1153 (s), 1041 (s), 985 (m), 830 (s). MS (EI): $344.2\left(\mathrm{M}^{+}\right)$.

\section{(4-Chlorophenyl)(4-((2-methyl-4-(triisopropylsilyl)but-3-yn-2-yl)oxy)phenyl)methanone} $(4 \mathbf{j})$<smiles>CC(C)(C#C[AsH2])Oc1ccc(C(=O)c2ccc(Cl)cc2)cc1</smiles>

Starting from $\mathbf{2 j}$ (96 $\mathrm{mg}, 0.30 \mathrm{mmol}$ ), the crude product was purified by column chromatography (Pentane/Ethyl Acetate $=9: 1)$ to afford $\mathbf{4 j}$ as colorless oil $(64 \mathrm{mg}, 0.14 \mathrm{mmol}$, $47 \%$ )

Rf: 0.5 (Pentane/Ethyl Acetate = 9:1). ${ }^{1} \mathrm{H}$ NMR $\left(400 \mathrm{MHz}, \mathrm{CDCl}_{3}\right) \delta 7.72(\mathrm{~m}, J=8.6,4.9 \mathrm{~Hz}$, $4 \mathrm{H}, 4 \times \mathrm{ArCH}), 7.45(\mathrm{~d}, J=8.5 \mathrm{~Hz}, 2 \mathrm{H}, 2 \times \mathrm{ArCH}), 7.34(\mathrm{~d}, J=8.8 \mathrm{~Hz}, 2 \mathrm{H}, 2 \times \mathrm{ArCH}), 1.73$ (s, 6H, $\left.2 \times \mathrm{CH}_{3}\right), 1.13-0.96\left(\mathrm{~m}, 21 \mathrm{H}\right.$, TIPS). ${ }^{13} \mathrm{C} \mathrm{NMR}\left(101 \mathrm{MHz}, \mathrm{CDCl}_{3}\right) \delta 194.5,160.2$, 138.3, 136.5, 131.6, 131.2, 130.5, 128.5, 119.1, 108.7, 88.0, 73.0, 29.9, 18.6, 11.1. IR 2942 (m), $2865(\mathrm{~m}), 1724(\mathrm{w}), 1658(\mathrm{~s}), 1598(\mathrm{~s}), 1505(\mathrm{~m}), 1463(\mathrm{~m}), 1383(\mathrm{~m}), 1305(\mathrm{~m}), 1285$ (m), $1251(\mathrm{~m}), 1136(\mathrm{~s}), 1090(\mathrm{~m}), 1016(\mathrm{~m}), 928$ (s), $884(\mathrm{~s})$. HRMS (ESI) calcd for $\mathrm{C}_{27} \mathrm{H}_{35} \mathrm{ClNaO}_{2} \mathrm{Si}^{+}[\mathrm{M}+\mathrm{Na}]^{+}$477.1987; found 477.1999. 


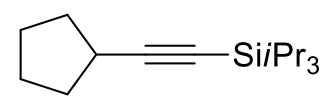

Starting from $2 \mathbf{k}(34 \mathrm{mg}, 32 \mu \mathrm{L}, 0.30 \mathrm{mmol}$ ) and using $1 \mathrm{~mol} \%$ of catalyst 3a, the crude product was purified by column chromatography (Pentane/Ethyl Acetate $=9: 1$ ) to afford $\mathbf{4 k}$ as colorless oil (48 mg, $0.19 \mathrm{mmol}, 64 \%$ ).

R: 0.9 (Pentane) ${ }^{1} \mathrm{H}$ NMR $\left(400 \mathrm{MHz}, \mathrm{CDCl}_{3}\right)^{[25]} \delta 22.74-2.60(\mathrm{~m}, 1 \mathrm{H}, \mathrm{CH}-\mathrm{C} \equiv \mathrm{C}), 1.97-$ $1.82\left(\mathrm{~m}, 2 \mathrm{H}, \mathrm{CH}_{2}\right), 1.81-1.46\left(\mathrm{~m}, 6 \mathrm{H}, \mathrm{CH}_{2}\right), 1.14-0.94(\mathrm{~m}, 21 \mathrm{H}, \mathrm{TIPS}) .{ }^{13} \mathrm{C}$ NMR $(101$ $\left.\mathrm{MHz}, \mathrm{CDCl}_{3}\right) \delta 114.1,79.0,34.2,31.2,24.9,18.6,11.3 . \mathrm{IR} 2943(\mathrm{~m}), 2865(\mathrm{~m}), 2361(\mathrm{w})$, $2159(\mathrm{w}), 2097(\mathrm{~m}), 1777(\mathrm{~m}), 1678(\mathrm{~m}), 1642(\mathrm{~m}), 1578(\mathrm{w}), 1512(\mathrm{w}), 1464(\mathrm{w}), 1383(\mathrm{w})$, $1223(\mathrm{~m}), 1138(\mathrm{~m}), 996(\mathrm{~s}), 919(\mathrm{~s}), 883(\mathrm{~s})$. The data correspond to the reported values. ${ }^{[26]}$

\section{(Cyclohexylethynyl)triisopropylsilane (41)}

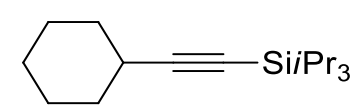

Starting from 21 (39 mg, $0.30 \mathrm{mmol}$ ) and using $2 \mathrm{~mol} \%$ of catalyst 3a, the crude product was purified by column chromatography (100\% Pentane) to afford $\mathbf{4 l}$ as colorless oil (38 $\mathbf{m g}, 0.14$ mmol, $48 \%$ ).

Rf: 0.9 (Pentane). ${ }^{1} \mathrm{H}$ NMR $\left(400 \mathrm{MHz}, \mathrm{CDCl}_{3}\right)^{[25]} \delta 2.49-2.41(\mathrm{~m}, 1 \mathrm{H}, \mathrm{CH}), 1.80-1.66(\mathrm{~m}$, $\left.4 \mathrm{H}, 2 \times \mathrm{CH}_{2}\right), 1.54-1.41\left(\mathrm{~m}, 3 \mathrm{H}, \mathrm{CH}_{2}\right), 1.41-1.19\left(\mathrm{~m}, 3 \mathrm{H}, \mathrm{CH}_{2}\right), 1.13-0.96(\mathrm{~m}, 21 \mathrm{H}$, TIPS). ${ }^{13} \mathrm{C} \mathrm{NMR}\left(101 \mathrm{MHz}, \mathrm{CDCl}_{3}\right) \delta 113.6,79.5,32.7,29.9,26.0,24.5,18.5,11.4 . \mathrm{IR} 2940$ (s), 2865 (s), $2171(\mathrm{w}), 2098$ (m), 1463 (m), 1384 (w), 1367 (w), 1235 (w), 1075 (w), 997 (m), $920(\mathrm{~m}), 883(\mathrm{~s})$. The data correspond to the reported values. ${ }^{[26]}$

\section{(Adamantan-1-ylethynyl)triisopropylsilane (4m)}

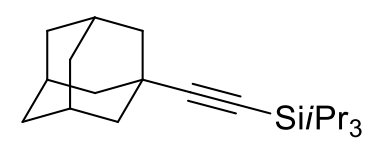

Starting from $\mathbf{2 m}(54 \mathrm{mg}, 0.30 \mathrm{mmol})$ and using $2 \mathrm{~mol} \%$ of catalyst $\mathbf{3 a}$, the crude product was purified by column chromatography (100\% Pentane) to afford $\mathbf{4 m}$ as colorless oil (42 $\mathbf{m g}$, $0.13 \mathrm{mmol}, 44 \%)$.

Rf: 0.85 (Pentane) ${ }^{1} \mathrm{H}$ NMR $\left(400 \mathrm{MHz}, \mathrm{CDCl}_{3}\right) \delta 1.96-1.91(\mathrm{~m}, 3 \mathrm{H}, 3$ x $C H), 1.88$ (dd, $J=$ $\left.3.1,3.1 \mathrm{~Hz}, 6 \mathrm{H}, 3 \times \mathrm{CH}_{2}\right), 1.68\left(\mathrm{dd}, J=3.1,3.1 \mathrm{~Hz}, 6 \mathrm{H}, 3 \times \mathrm{CH}_{2}\right), 1.12-1.00(\mathrm{~m}, 21 \mathrm{H}$, TIPS). ${ }^{13} \mathrm{C} \mathrm{NMR}\left(101 \mathrm{MHz}, \mathrm{CDCl}_{3}\right) \delta 118.1,77.3,43.1,36.4,30.4,28.0,19.9,18.5,11.4$. IR 2920 (s), 2865 (s), 2164 (w), 2098 (m), 1464 (m), 1383 (w), 1247 (w), 1155 (w), 1017 (w), $997(\mathrm{~m}), 923(\mathrm{~m}), 883(\mathrm{~s})$. The data correspond to the reported values. ${ }^{[27]}$

[24] Contains 5\% of unseparable impurities (probably TIPS alkyne dimer).

[26] X. Liu, Z. Wang, X. Cheng, C. Li, J. Am. Chem. Soc. 2012, 134, 14330.

[27] R. H. Pouwer, J. B. Harper, K. Vyakaranam, J. Michl, C. M. Williams, C. H. Jessen, P. V. Bernhardt, Eur. J. Org. Chem. 2007, 2007, 241-248. 


\section{Benzyl 2-((tert-butyldiphenylsilyl)ethynyl)pyrrolidine-1-carboxylate (4n)}

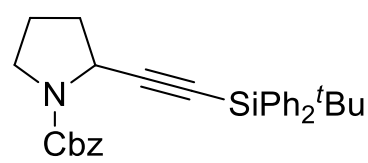

Starting from 2a (46 $\mathrm{mg}, 0.20 \mathrm{mmol}$ ), the crude product was purified by column chromatography $($ Pentane/Ethyl Acetate $=9: 1)$ to afford $\mathbf{4 n}$ as yellow oil $(70 \mathrm{mg}, 0.16 \mathbf{m m o l}$, $78 \%)$.

$\mathrm{R}_{\mathrm{f}}: 0.25$ (Pentane/Ethyl Acetate $\left.=9: 1\right)^{1} \mathrm{H}$ NMR $\left(400 \mathrm{MHz}, \mathrm{CDCl}_{3}\right) \delta 7.88-7.70(\mathrm{~m}, 4 \mathrm{H}, 4 \mathrm{x}$ $\operatorname{ArCH}), 7.45-7.29(\mathrm{~m}, 9 \mathrm{H}, 9 \times \mathrm{ArCH}), 7.29-7.19(\mathrm{~m}, 2 \mathrm{H}, 2 \mathrm{x} \operatorname{ArCH}), 5.29-5.12(\mathrm{~m}, 2 \mathrm{H}$, $\left.\mathrm{CH}_{2}-\mathrm{O}\right), 4.83-4.66(\mathrm{~m}, 1 \mathrm{H}, \mathrm{CH}-\mathrm{C} \equiv \mathrm{C}), 3.74-3.55(\mathrm{~m}, 1 \mathrm{H}, \mathrm{CH}-\mathrm{N}), 3.54-3.35(\mathrm{~m}, 1 \mathrm{H}$, $\left.\mathrm{CH}_{2}\right), 2.31-2.07\left(\mathrm{~m}, \mathrm{~J}=6.2 \mathrm{~Hz}, 3 \mathrm{H}, \mathrm{CH}+\mathrm{CH}_{2}\right), 2.04-1.89(\mathrm{~m}, 1 \mathrm{H}, \mathrm{CH}), 1.06(\mathrm{~s}, 9 \mathrm{H}, 3 \mathrm{x}$ $\left.\mathrm{CH}_{3}\right) .{ }^{13} \mathrm{C}$ NMR $\left(101 \mathrm{MHz}, \mathrm{CDCl}_{3}\right)^{[22]} \delta 154.6,154.4,137.0,136.7,135.6,135.6,133.3$, $133.3,129.5,128.5,127.9,127.8,127.75,127.70,110.2,82.0,67.1,66.9,49.4,49.0,46.2$, 45.7, 34.2, 33.2, 27.1, 24.7, 23.9, 18.6. IR 3070 (w), 3047 (w), 2955 (m), 2931 (m), $2891(\mathrm{w})$, $2857(\mathrm{~m}), 2173$ (w), 1705 (s), 1428 (m), 1410 (s), 1356 (s), 1331 (m), 1265 (m), 1187 (s), $1111(\mathrm{~s}), 996(\mathrm{w}), 912(\mathrm{~m}), 822(\mathrm{~m})$. HRMS (ESI) calcd for $\mathrm{C}_{30} \mathrm{H}_{33} \mathrm{NNaO}_{2} \mathrm{Si}^{+}[\mathrm{M}+\mathrm{Na}]^{+}$ 490.2173; found 490.2173.

\section{Benzyl 2-(phenylethynyl)pyrrolidine-1-carboxylate (4o)}

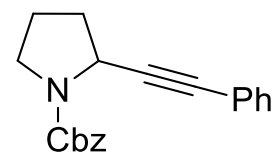

Starting from 2a $(75 \mathrm{mg}, 0.30 \mathrm{mmol})$, the crude product was purified by column chromatography (Pentane/Ethyl Acetate $=9: 1)$ to afford 40 as yellow oil $(89 \mathrm{mg}, 0.29 \mathrm{mmol}$, 97\%).

$\mathrm{R}_{\mathrm{f}}: 0.25$ (Pentane/Ethyl Acetate = 9:1). ${ }^{1} \mathrm{H} \mathrm{NMR}\left(400 \mathrm{MHz}, \mathrm{CDCl}_{3}\right) \delta 7.26(\mathrm{~m}, 10 \mathrm{H}, 2 \mathrm{x} P h)$, $5.43-5.02\left(\mathrm{~m}, 2 \mathrm{H}, \mathrm{CH}_{2} \mathrm{Ph}\right), 4.93-4.65(\mathrm{~m}, 1 \mathrm{H}, \mathrm{CH}-\mathrm{C} \equiv \mathrm{C}), 3.72-3.53\left(\mathrm{~m}, 1 \mathrm{H}, \mathrm{N}-\mathrm{CH}_{2}\right), 3.53$ $-3.29\left(\mathrm{~m}, 1 \mathrm{H}, \mathrm{N}-\mathrm{CH}_{2}\right), 2.33-2.07\left(\mathrm{~m}, 3 \mathrm{H}, \mathrm{CH}_{2}\right), 2.03-1.86\left(\mathrm{~m}, 1 \mathrm{H}, \mathrm{CH}_{2}\right) .{ }^{13} \mathrm{C}$ NMR $(101$ $\left.\mathrm{MHz}, \mathrm{CDCl}_{3}\right)^{[22]} \delta 154.5,137.0,131.8,131.7,128.4,128.2,128.1,128.0,127.7,127.6,123.0$, 89.5, 82.2, 66.8, 49.2, 48.7, 46.2, 45.8, 34.0, 33.3, 24.5, 23.8. IR 3059 (w), 2988 (w), 1788 (w), $1721(\mathrm{~m}), 1697(\mathrm{~m}), 1491(\mathrm{w}), 1418(\mathrm{~s}), 1358(\mathrm{~m}), 1296(\mathrm{~m}), 1266(\mathrm{~s}), 1177$ (s), 1116 (m), 1089 (m), 1023 (w), 915 (w). HRMS (ESI) calcd for $\mathrm{C}_{20} \mathrm{H}_{20} \mathrm{NO}_{2}{ }^{+}[\mathrm{M}+\mathrm{H}]^{+}$306.1489; found 306.1490.

\section{Benzyl 2-(mesitylethynyl)pyrrolidine-1-carboxylate (4p)}<smiles>Cc1cc(C)c(C#CC2CCCN2C(=O)OCc2ccccc2)c(C)c1</smiles> 
Starting from 2a $(60 \mathrm{mg}, 0.24 \mathrm{mmol})$, the crude product was purified by column chromatography (Pentane/Ethyl Acetate $=9: 1)$ to afford $\mathbf{4 p}$ as colorless oil $(51.8 \mathrm{mg}, 0.149$ mmol, 62\%).

$\mathrm{R}_{\mathrm{f}}: 0.28$ (Pentane/Ethyl Acetate = 9:1). ${ }^{1} \mathrm{H}$ NMR $\left(400 \mathrm{MHz}, \mathrm{CDCl}_{3}\right) \delta 7.54-7.20(\mathrm{~m}, 5 \mathrm{H}, P h)$, 6.83 (s, 2H, Mesityl), 5.20 (s, 2H, $\left.\mathrm{CH}_{2} \mathrm{Ph}\right), 5.02-4.77$ (m, $\left.1 \mathrm{H}, \mathrm{CH}-\mathrm{C} \equiv \mathrm{C}\right), 3.74-3.54\left(\mathrm{~m}, 1 \mathrm{H}, \mathrm{N}-\mathrm{CH}_{2}\right.$ ), $3.54-3.28\left(\mathrm{~m}, 1 \mathrm{H}, \mathrm{N}-\mathrm{CH}_{2}\right), 2.46-2.22\left(\mathrm{~m}, 9 \mathrm{H}, 3 \times \mathrm{CH}_{3}\right), 2.22-2.10\left(\mathrm{~m}, 3 \mathrm{H}, \mathrm{CH}_{2}\right), 2.03-1.93(\mathrm{~m}$, $\left.1 \mathrm{H}, \mathrm{CH}_{2}\right) .{ }^{13} \mathrm{C} \mathrm{NMR}\left(101 \mathrm{MHz}, \mathrm{CDCl}_{3}\right)^{[22]} \delta 154.6,154.3,140.1,137.5,137.4,136.9,136.8,128.4$, 127.8, 127.7, 127.5, 119.7, 119.6, 97.0, 96.8, 80.1, 66.9, 66.8, 60.4, 49.4, 49.1, 46.1, 45.6, 34.3, 33.5, 24.5, 23.7, 21.3, 20.8. IR $2984(\mathrm{w}), 1700$ (m), 1481 (m), 1409 (m), 1357 (s), 1334 (s), 1271 (s), 1185 (s), 1109 (m), 1087 (m), 1031 (m), 912 (m), 852 (m). HRMS (ESI) calcd for $\mathrm{C}_{23} \mathrm{H}_{26} \mathrm{NO}_{2}^{+}[\mathrm{M}+\mathrm{H}]^{+}$348.1958; found 348.1952.

\section{Benzyl 2-((4-(trifluoromethyl)phenyl)ethynyl)pyrrolidine-1-carboxylate (4q)}

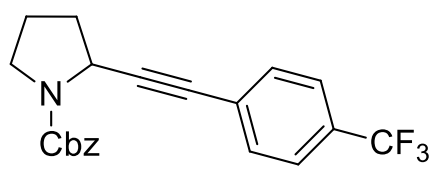

Starting from 2a $(75 \mathrm{mg}, 0.30 \mathrm{mmol})$, the crude product was purified by column chromatography (Pentane/Ethyl Acetate $=9: 1)$ to afford $\mathbf{4 q}$ as colorless oil $(95 \mathrm{mg}, 0.25$ mmol, $85 \%)$.

$\mathrm{R}_{\mathrm{f}}: 0.30$ (Pentane/Ethyl Acetate = 9:1). ${ }^{1} \mathrm{H}$ NMR $\left(400 \mathrm{MHz}, \mathrm{CDCl}_{3}\right) \delta 7.44-6.84(\mathrm{~m}, 9 \mathrm{H}, \mathrm{Ph}$ $+A r \mathrm{H}), 5.19-4.74\left(\mathrm{~m}, 2 \mathrm{H}, \mathrm{CH}_{2} \mathrm{O}\right), 4.69-4.37(\mathrm{~m}, 1 \mathrm{H}, \mathrm{CH}-\mathrm{C} \equiv \mathrm{C}), 3.49-3.27(\mathrm{~m}, 1 \mathrm{H}$, $\left.\mathrm{NCH}_{2}\right), 3.28-3.03\left(\mathrm{~m}, 1 \mathrm{H}, \mathrm{NCH}_{2}\right), 2.10-1.79\left(\mathrm{~m}, 3 \mathrm{H}, \mathrm{CH}_{2}\right), 1.79-1.60\left(\mathrm{~m}, 1 \mathrm{H}, \mathrm{CH}_{2}\right) .{ }^{13} \mathrm{C}$ NMR $\left(101 \mathrm{MHz}, \mathrm{CDCl}_{3}\right)^{[22,28]} \delta 154.5,136.9(\mathrm{~m}), 132.1,131.9,130.0,128.4,128.0,127.8$, 127.7, 126.8, 125.1, 123.9 (q, $J=272.0 \mathrm{~Hz}$ ), 119.9, 92.0, 81.0, 76.7, 66.9, 49.1, 48.6, 46.3, 45.9, 33.8, 33.1, 29.7, 24.6, 23.8. IR 2991 (w), 2197 (w), 1705 (m), 1614 (w), 1410 (s), 1357 (m), 1323 (s), 1124 (s), 1067 (s), 968 (w), 911 (w), 844 (m). HRMS (ESI) calcd for $\mathrm{C}_{21} \mathrm{H}_{18} \mathrm{~F}_{3} \mathrm{NNaO}_{2}{ }^{+}[\mathrm{M}+\mathrm{Na}]^{+}$396.1182; found 396.1181.

\section{Benzyl 2-((4-bromophenyl)ethynyl)pyrrolidine-1-carboxylate (4r)}

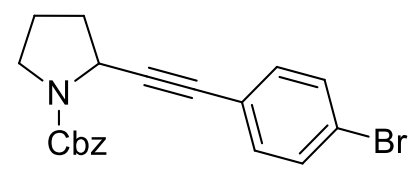

Starting from 2a $(75 \mathrm{mg}, 0.30 \mathrm{mmol})$, the crude product was purified by column chromatography (Pentane/Ethyl Acetate $=9: 1)$ to afford $\mathbf{4 r}$ as colorless oil $(76 \mathrm{mg}, 0.20 \mathrm{mmol}$, $66 \%)$.

$\mathrm{R}_{\mathrm{f}}: 0.28$ (Pentane/Ethyl Acetate = 9:1). ${ }^{1} \mathrm{H}$ NMR $\left(400 \mathrm{MHz}, \mathrm{CDCl}_{3}\right) \delta 7.55-7.08(\mathrm{~m}, 9 \mathrm{H}, 2 \mathrm{x}$ $A r), 5.43-5.03\left(\mathrm{~m}, 2 \mathrm{H}, \mathrm{CH}_{2} \mathrm{Ph}\right), 4.92-4.65(\mathrm{~m}, 1 \mathrm{H}, \mathrm{CH}-\mathrm{C} \equiv \mathrm{C}), 3.70-3.52\left(\mathrm{~m}, 1 \mathrm{H}, \mathrm{N}-\mathrm{CH}_{2}\right)$,

[28] Due to peaks overlap, not all C-F coupling constants could be resolved. 
$3.52-3.31\left(\mathrm{~m}, 1 \mathrm{H}, \mathrm{N}-\mathrm{CH}_{2}\right), 2.29-2.03\left(\mathrm{~m}, 3 \mathrm{H}, \mathrm{CH}_{2}\right), 2.03-1.82\left(\mathrm{~m}, 1 \mathrm{H}, \mathrm{CH}_{2}\right) .{ }^{13} \mathrm{C}$ NMR $\left(101 \mathrm{MHz}, \mathrm{CDCl}_{3}\right)^{[22]} \delta 154.5,136.9,133.3,133.1,131.4,130.1,128.4,128.4,128.0,127.8$, 127.6, 122.3, 121.9, 90.7, 90.3, 81.2, 66.9, 53.5, 49.2, 48.7, 46.3, 45.9, 33.9, 33.2, 30.9, 29.7, 24.6, 23.8, 18.52 . IR 3032 (w), 2803 (w), 1699 (m), 1586 (w), 1487 (m), $1411(\mathrm{w}), 1344(\mathrm{~s})$, 1304 (s), 1185 (m), 1114 (m), 1088 (m), 1010 (s), 911 (m), 825 (s). HRMS (ESI) calcd for $\mathrm{C}_{20} \mathrm{H}_{18} \mathrm{BrNNaO}_{2}{ }^{+}[\mathrm{M}+\mathrm{Na}]^{+}$406.0413; found 406.0423.

\section{Benzyl 2-((2-bromophenyl)ethynyl)pyrrolidine-1-carboxylate (4s)}

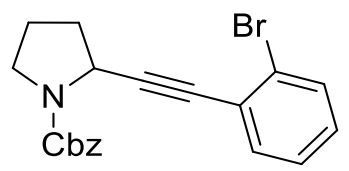

Starting from 2a $(75 \mathrm{mg}, 0.30 \mathrm{mmol})$, the crude product was purified by column chromatography (Pentane/Ethyl Acetate $=9: 1)$ to afford $4 \mathrm{~s}$ as colorless oil $(102 \mathrm{mg}, 0.270$ mmol, $88 \%$ ).

$\mathrm{R}_{\mathrm{f}}: 0.28$ (Pentane/Ethyl Acetate = 9:1). ${ }^{1} \mathrm{H}$ NMR $\left(400 \mathrm{MHz}, \mathrm{CDCl}_{3}\right) \delta 7.56(\mathrm{~d}, J=8.0 \mathrm{~Hz}, 1 \mathrm{H}$, CH Bromophenyl), $7.49-7.27$ (m, 6H, 5 x CH benzyl + CH Bromophenyl), 7.22 (td, J = 7.6, $1.3 \mathrm{~Hz}, 1 \mathrm{H}, \mathrm{CH}$ Bromophenyl), 7.14 (q, J = 6.9, 6.4 Hz, 1H, CH Bromophenyl), 5.36 - 5.10 $\left(\mathrm{m}, 2 \mathrm{H}, \mathrm{CH}_{2}-\mathrm{O}\right), 4.92-4.76(\mathrm{~m}, 1 \mathrm{H}, \mathrm{CH}-\mathrm{C} \equiv \mathrm{C}), 3.70-3.56\left(\mathrm{~m}, 1 \mathrm{H}, \mathrm{N}-\mathrm{CH}_{2}\right), 3.52-3.36(\mathrm{~m}$, $\left.1 \mathrm{H}, \mathrm{N}-\mathrm{CH}_{2}\right), 2.34-2.09\left(\mathrm{~m}, 3 \mathrm{H}, \mathrm{CH}+\mathrm{CH}_{2}\right), 2.04-1.95(\mathrm{~m}, 1 \mathrm{H}, \mathrm{CH}) .{ }^{13} \mathrm{C} \mathrm{NMR}(101 \mathrm{MHz}$, $\left.\mathrm{CDCl}_{3}\right)^{[22]} \delta 154.5,136.9,133.5,133.3,132.3,132.3,129.4,129.3,128.4,128.4,128.0,127.8$, $127.7,126.9,125.9,125.7,125.1,125.0,94.2,94.0,81.0,66.9,49.3,48.9,46.2,45.7,33.9$, 33.2, 29.7, 24.6, 23.8. IR 3064 (w), 3033 (w), 2982 (w), 2952 (w), 2881 (w), 1703 (s), 1469 (m), 1410 (s), 1356 (s), 1334 (m), 1268 (w), 1180 (m), 1116 (m), 1089 (m), 1027 (w), 915 (w). HRMS (ESI) calcd for $\mathrm{C}_{20} \mathrm{H}_{18} \mathrm{BrNNaO}_{2}{ }^{+}[\mathrm{M}+\mathrm{Na}]^{+} 406.0413$; found 406.0415.

\section{Benzyl 2-(hexadec-1-yn-1-yl)pyrrolidine-1-carboxylate (4t)}

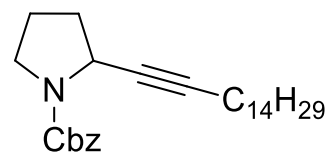

Starting from $2 \mathbf{a}(75 \mathrm{mg}, 0.30 \mathrm{mmol})$ and using $1 \mathrm{~mol} \%$ of catalyst $\mathbf{3 a}$, the crude product was purified by column chromatography (Pentane/Ethyl Acetate $=9: 1$ ) to afford $\mathbf{4 t}$ as colorless oil (87 mg, $0.204 \mathrm{mmol}, 68 \%$ ).

$\mathrm{R}_{\mathrm{f}}: 0.20$ (Pentane/Ethyl Acetate = 9:1). ${ }^{1} \mathrm{H}$ NMR $\left(400 \mathrm{MHz}, \mathrm{CDCl}_{3}\right)^{[29]} \delta 7.48-7.27(\mathrm{~m}, 5 \mathrm{H}$, $\mathrm{Ph}), 5.31-5.08\left(\mathrm{~m}, 2 \mathrm{H}, \mathrm{CH}_{2} \mathrm{Ph}\right), 4.63-4.48(\mathrm{~m}, 1 \mathrm{H}, \mathrm{CH}-\mathrm{C} \equiv \mathrm{C}), 3.61-3.46\left(\mathrm{~m}, 1 \mathrm{H}, \mathrm{N}-\mathrm{CH}_{2}\right)$, $3.46-3.24\left(\mathrm{~m}, 1 \mathrm{H}, \mathrm{N}-\mathrm{CH}_{2}\right), 2.24-1.77\left(\mathrm{~m}, 4 \mathrm{H}, \mathrm{CH}_{2}\right), 1.53-1.38\left(\mathrm{~m}, 2 \mathrm{H}, \mathrm{CH}_{2}\right), 1.38-1.18$ $\left(\mathrm{m}, 24 \mathrm{H}, 12 \times \mathrm{CH}_{2}\right), 0.88\left(\mathrm{t}, J=6.8 \mathrm{~Hz}, 3 \mathrm{H}, \mathrm{CH}_{3}\right) .{ }^{13} \mathrm{C} \mathrm{NMR}\left(101 \mathrm{MHz}, \mathrm{CDCl}_{3}\right)^{[22]} \delta 154.6$, $137.1,133.2$, 129.8, 129.7, 128.4, 128.4, 127.9, 127.7, 127.5, 82.6, 66.7, 62.8, 48.8, 48.4, $46.1,45.7,34.2,33.5,31.9,29.72,29.70,29.68,29.66,29.6,29.4,29.1,28.9,28.7,24.4,23.6$,

[29] About $95 \%$ pure by ${ }^{1} \mathrm{H}$ NMR. 
22.7, 18.7, 14.1. IR 2925 (s), 2853 (s), 2359 (w), 1806 (w), 1766 (m), 1732 (m), 1715 (m), 1643 (w), 1511 (w), 1468 (m), 1343 (m), 1265 (s), 1195 (m), 1139 (m), 1104 (w), 929 (m), 902 (m). HRMS (ESI) calcd for $\mathrm{C}_{28} \mathrm{H}_{44} \mathrm{NO}_{2}{ }^{+}[\mathrm{M}+\mathrm{H}]^{+} 426.3367$; found 426.3361 .

\section{Benzyl 2-(3,3-dimethylbut-1-yn-1-yl)pyrrolidine-1-carboxylate (4u)}<smiles>CC(C)(C)C#CC1CCCN1C(=O)OCc1ccccc1</smiles>

Starting from 2a $(75 \mathrm{mg}, 0.30 \mathrm{mmol})$, the crude product was purified by column chromatography (Pentane/Ethyl Acetate $=9: 1)$ to afford $\mathbf{4 u}$ as colorless oil $(66 \mathrm{mg}, 0.23$ mmol, $77 \%$ ).

$\mathrm{R}_{\mathrm{f}}$ : 0.28 (Pentane/Ethyl Acetate = 9:1). ${ }^{1} \mathrm{H}$ NMR $\left(400 \mathrm{MHz}, \mathrm{CDCl}_{3}\right) \delta 7.54-7.19(\mathrm{~m}, 5 \mathrm{H}$, $\mathrm{Ph}), 5.39-4.98\left(\mathrm{~m}, 2 \mathrm{H}, \mathrm{CH}_{2} \mathrm{Ph}\right), 4.65-4.42(\mathrm{~m}, 1 \mathrm{H}, \mathrm{CH}-\mathrm{C} \equiv \mathrm{C}), 3.62-3.44\left(\mathrm{~m}, 1 \mathrm{H}, \mathrm{N}-\mathrm{CH}_{2}\right)$, $3.44-3.21\left(\mathrm{~m}, 1 \mathrm{H}, \mathrm{N}-\mathrm{CH}_{2}\right), 2.19-1.82\left(\mathrm{~m}, 4 \mathrm{H}, \mathrm{CH}_{2}\right), 1.16(\mathrm{~s}, 9 \mathrm{H}, t \mathrm{Bu}) .{ }^{13} \mathrm{C} \mathrm{NMR}(101$ $\left.\mathrm{MHz}, \mathrm{CDCl}_{3}\right)^{[22]} \delta 154.6,137.1,129.8,128.4,128.3,127.8,127.6,127.4,90.7,78.5,66.6$, 48.8, 48.3, 46.1, 45.6, 34.3, 33.6, 31.0, 29.7, 27.2, 24.3, 23.6. IR 2970 (m), 2875 (w), 2236 (w), 1704 (s), 1410 (s), 1357 (s), 1335 (s), 1269 (s), 1183 (m), 1122 (m), 1095 (m), 1012 (w), 917 (w). HRMS (ESI) calcd for $\mathrm{C}_{18} \mathrm{H}_{23} \mathrm{NNaO}_{2}{ }^{+}[\mathrm{M}+\mathrm{Na}]^{+} 308.1621$; found 308.1620. 


\section{Further functionalization:}

\section{Benzyl 2-(1-benzyl-1H-1,2,3-triazol-4-yl)pyrrolidine-1-carboxylate (5)}

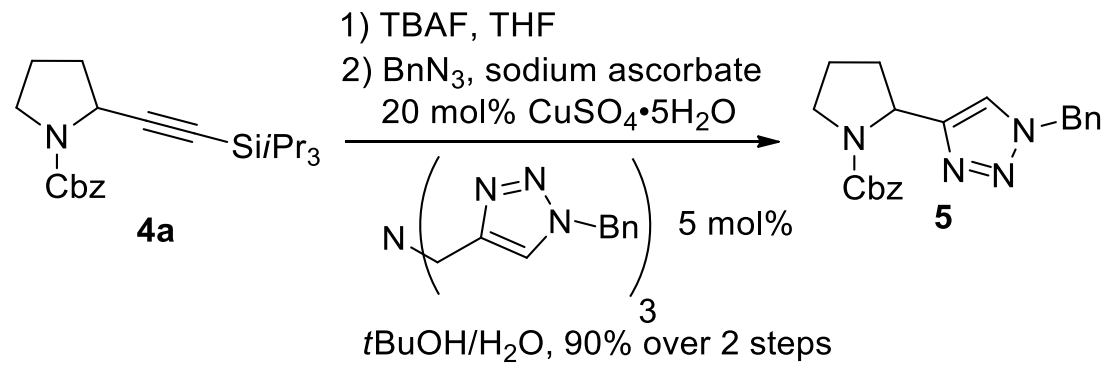

Following a reported procedure, ${ }^{[30]}$ 4a $(344 \mathrm{mg}, 0.890 \mathrm{mmol}, 1$ equiv) was dissolved in dry THF $(11 \mathrm{~mL}, 0.08 \mathrm{M})$ in a flame dried flask and the solution was cooled to $0{ }^{\circ} \mathrm{C}$. Then TBAF (1.1 mL, $1.1 \mathrm{mmol}, 1.2$ equiv, $1.0 \mathrm{M}$ in hexanes) was added dropwise and the reaction left stirring for 30 minutes. Then the reaction was quenched with sat $\mathrm{NH}_{4} \mathrm{Cl}$ solution $(20 \mathrm{~mL})$. The aqueous and organic layers were separated and the aqueous layer was extracted with ether $(3 \times 10 \mathrm{~mL})$. After drying over $\mathrm{MgSO}_{4}$ and concentrating under vacuum, the crude product was immediately used in the next step. Rf: 0.30 (6:1 Pentane:EtOAc, $\mathrm{KMnO}_{4}$ ).

Following a reported, ${ }^{[31]}$ benzyl 2-ethynylpyrrolidine-1-carboxylate $(205 \mathrm{mg}, 0.890 \mathrm{mmol}, 1$ equiv), (azidomethyl)benzene ( $134 \mu \mathrm{L}, 1.10 \mathrm{mmol}, 1.2$ equiv), sodium ascorbate $(71 \mathrm{mg}, 0.36$ mmol, 0.4 equiv), $\mathrm{CuSO}_{4} \bullet 5 \mathrm{H}_{2} \mathrm{O}(45 \mathrm{mg}, 0.18 \mathrm{mmol}, 0.20$ equiv) and tris((1-benzyl-1H-1,2,3triazol-4-yl)methyl)amine ( $24 \mathrm{mg}, 0.045 \mathrm{mmol}, 0.05$ equiv) were dissolved a 2:1 mixture of t $\mathrm{BuOH}: \mathrm{H}_{2} \mathrm{O}(9 \mathrm{~mL})$ in an open flask and left stirring for $2 \mathrm{~h}$. Then the crude product was purified via flash chromatography on silica (from 4:1 to 2:1 Pentane:EtOAc) to afford 5 (292 $\mathrm{mg}, 0.810 \mathrm{mmol}, 90 \%$ yield).

Rf: 0.20 (2:1 Pentane:EtOAc). ${ }^{1} \mathrm{H}$ NMR $\left(400 \mathrm{MHz}, \mathrm{CDCl}_{3}\right) \delta 7.55-7.01(\mathrm{~m}, 11 \mathrm{H}, 2 \times \mathrm{Ph}+$ CHtriazole), $5.60-5.34\left(\mathrm{~m}, 2 \mathrm{H}, \mathrm{CH}_{2}\right), 5.22-4.94\left(\mathrm{~m}, 3 \mathrm{H}, \mathrm{CH}\right.$ and $\left.\mathrm{CH}_{2}\right), 3.65-3.44(\mathrm{~m}, 2 \mathrm{H}$, $\left.\mathrm{CH}_{2}\right), 2.57-1.87\left(\mathrm{~m}, 4 \mathrm{H}, \mathrm{CH}_{2}\right) .{ }^{13} \mathrm{C} \mathrm{NMR}\left(101 \mathrm{MHz}, \mathrm{CDCl}_{3}\right)^{[22]} \delta 154.9,154.7,150.4,149.3$, 136.9, 136.6, 134.8, 134.7, 129.1, 128.7, 128.6, 128.4, 128.1, 127.9, 127.9, 127.8, 122.3, 121.3, 66.8, 54.0, 53.5, 46.9, 46.6, 32.6, 30.9, 24.5, 23.4. IR 3053 (w), $2986(\mathrm{w}), 1697$ (s), 1590 (w), 1527 (w), 1498 (m), 1451 (m), 1414 (s), 1355 (m), 1268 (m), 1192 (m), 1176 (m), 1113 (m), 1051 (w), 913 (w). HRMS (ESI) calcd for $\mathrm{C}_{21} \mathrm{H}_{23} \mathrm{~N}_{4} \mathrm{O}_{2}{ }^{+}[\mathrm{M}+\mathrm{H}]^{+}$363.1816; found 363.1811

[30] Y. Li, J. Waser, Angew. Chem., Int. Ed. 2015, 54, 5438.

[31] Q.-H. Deng, T. Bleith, H. Wadepohl, L. H. Gade, J. Am. Chem. Soc. 2013, 135, 5356. 
5. Spectra for new compounds

${ }^{1}$ H-NMR (400 MHz, CDCl $)$

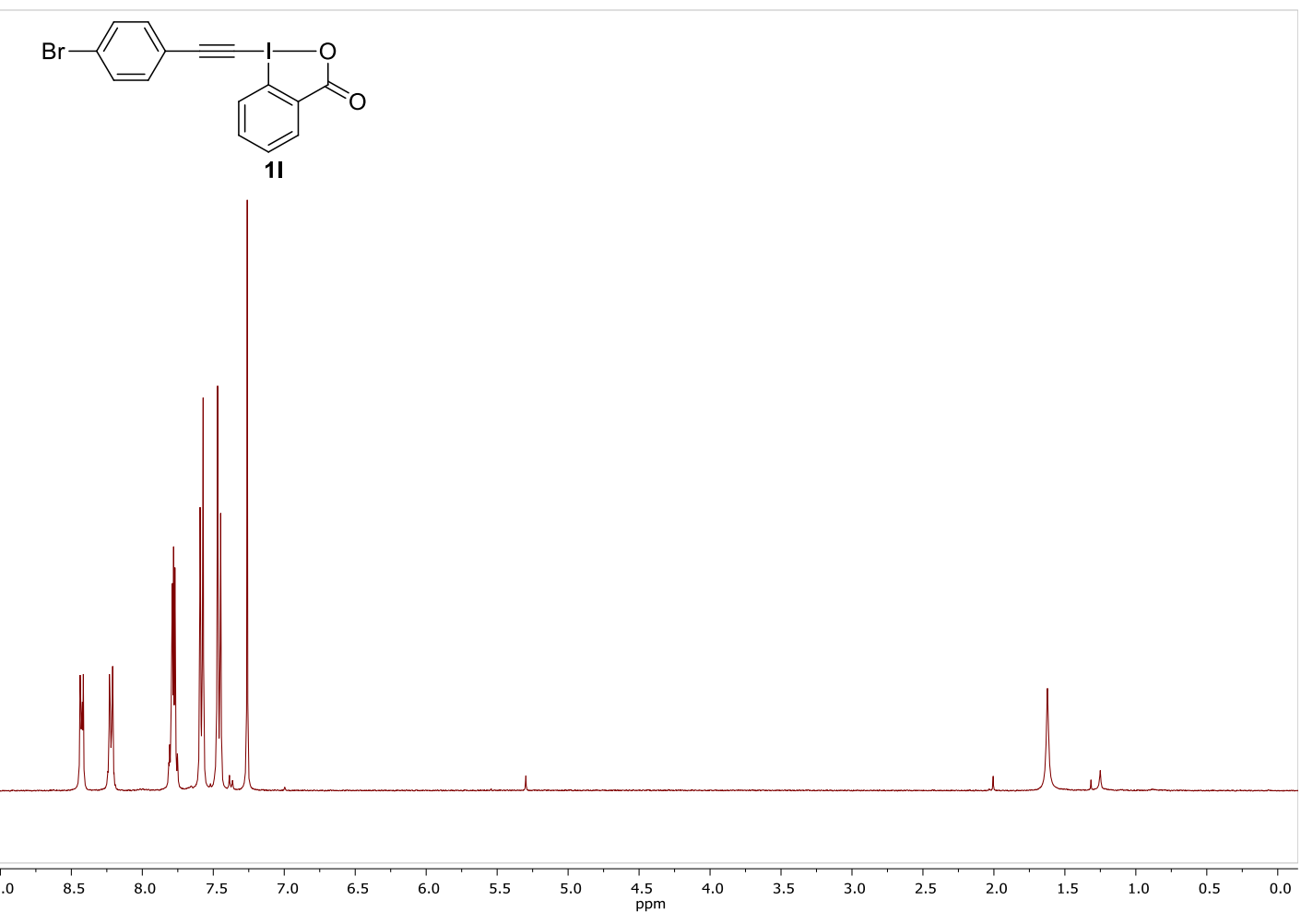

${ }^{13} \mathrm{C}-\mathrm{NMR}$ (101 MHz, $\left.\mathrm{CDCl}_{3}\right)$
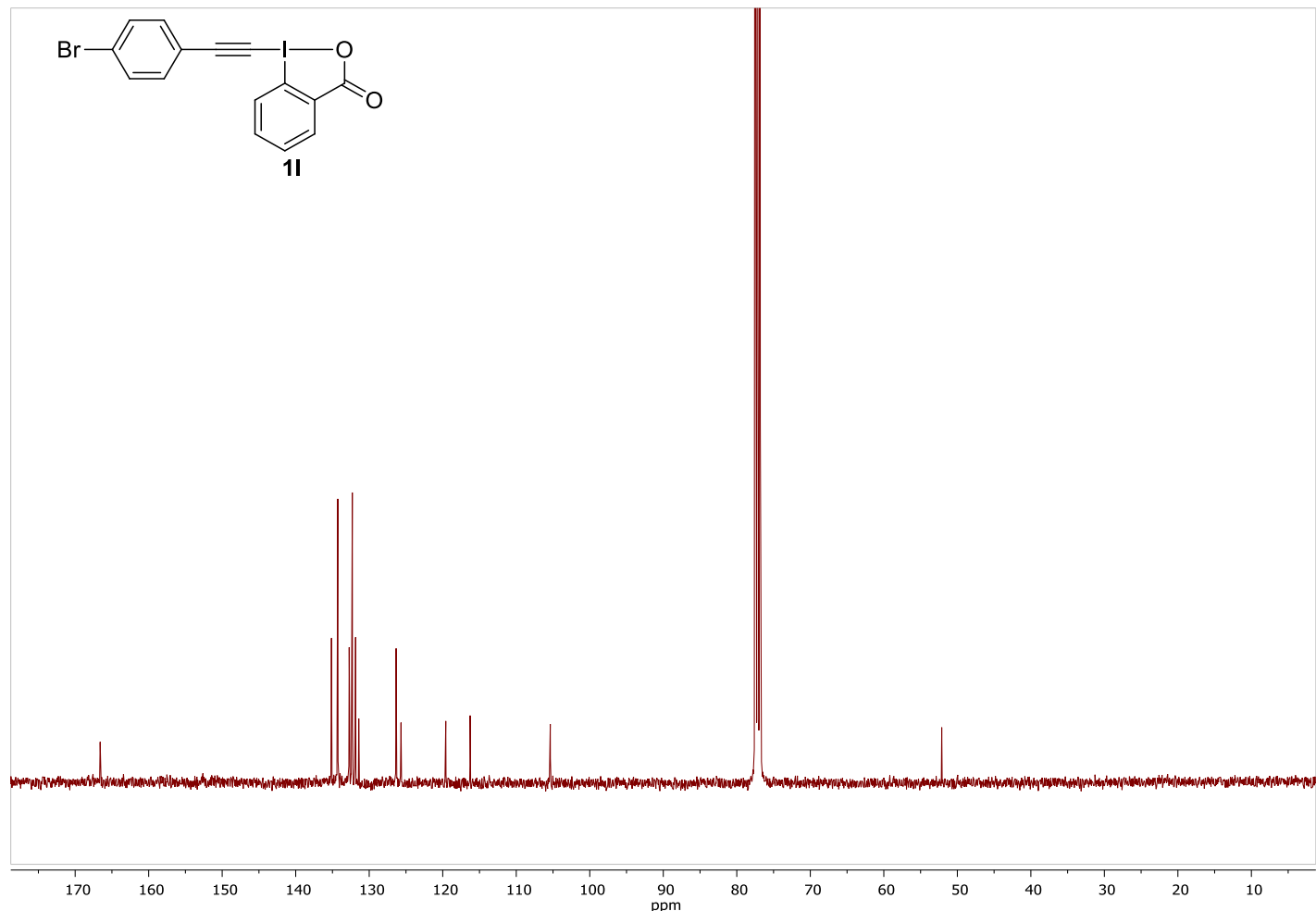
IR Spectra

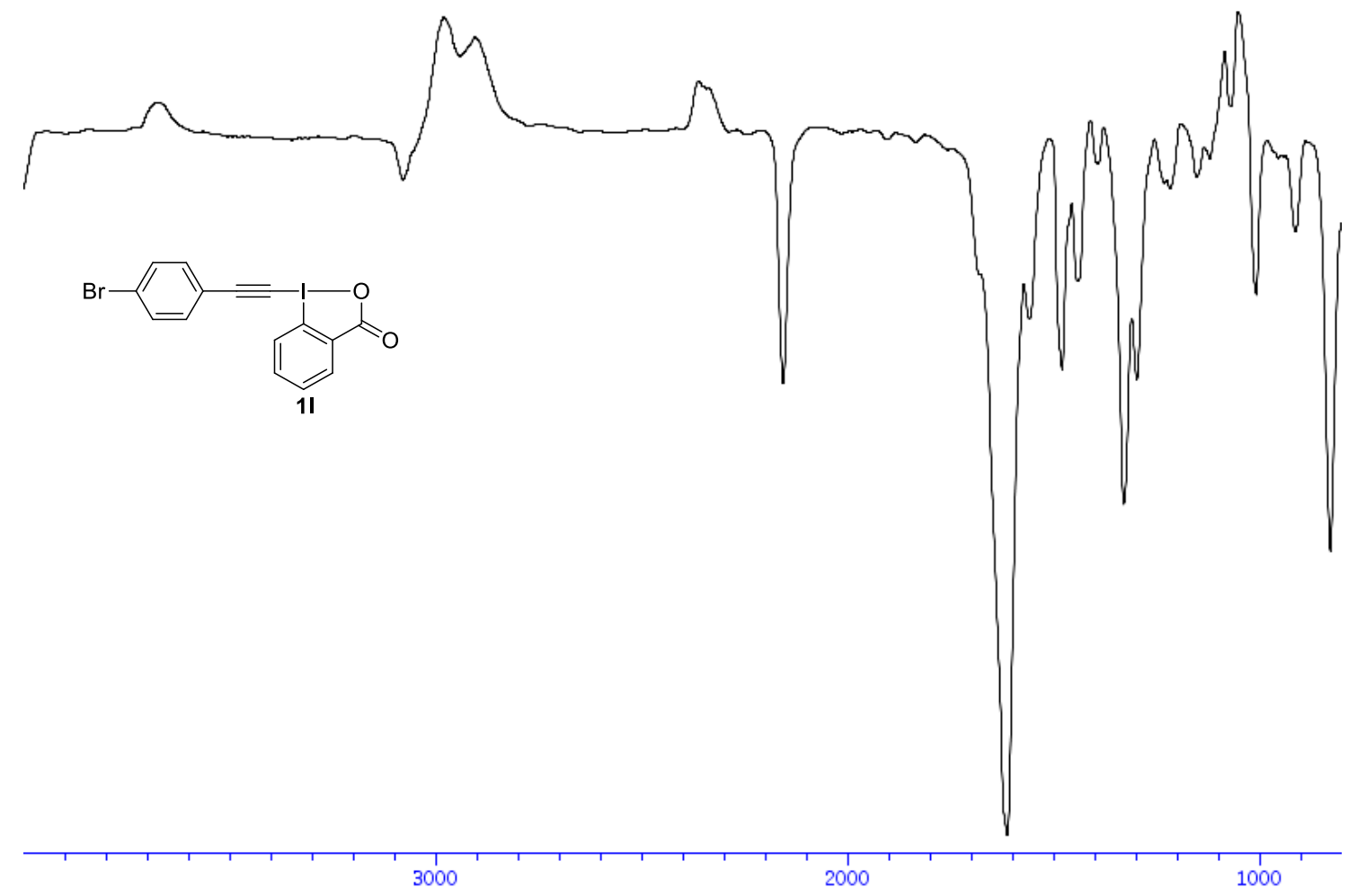


${ }^{1} \mathrm{H}-\mathrm{NMR}$ (400 MHz, CDCl3)

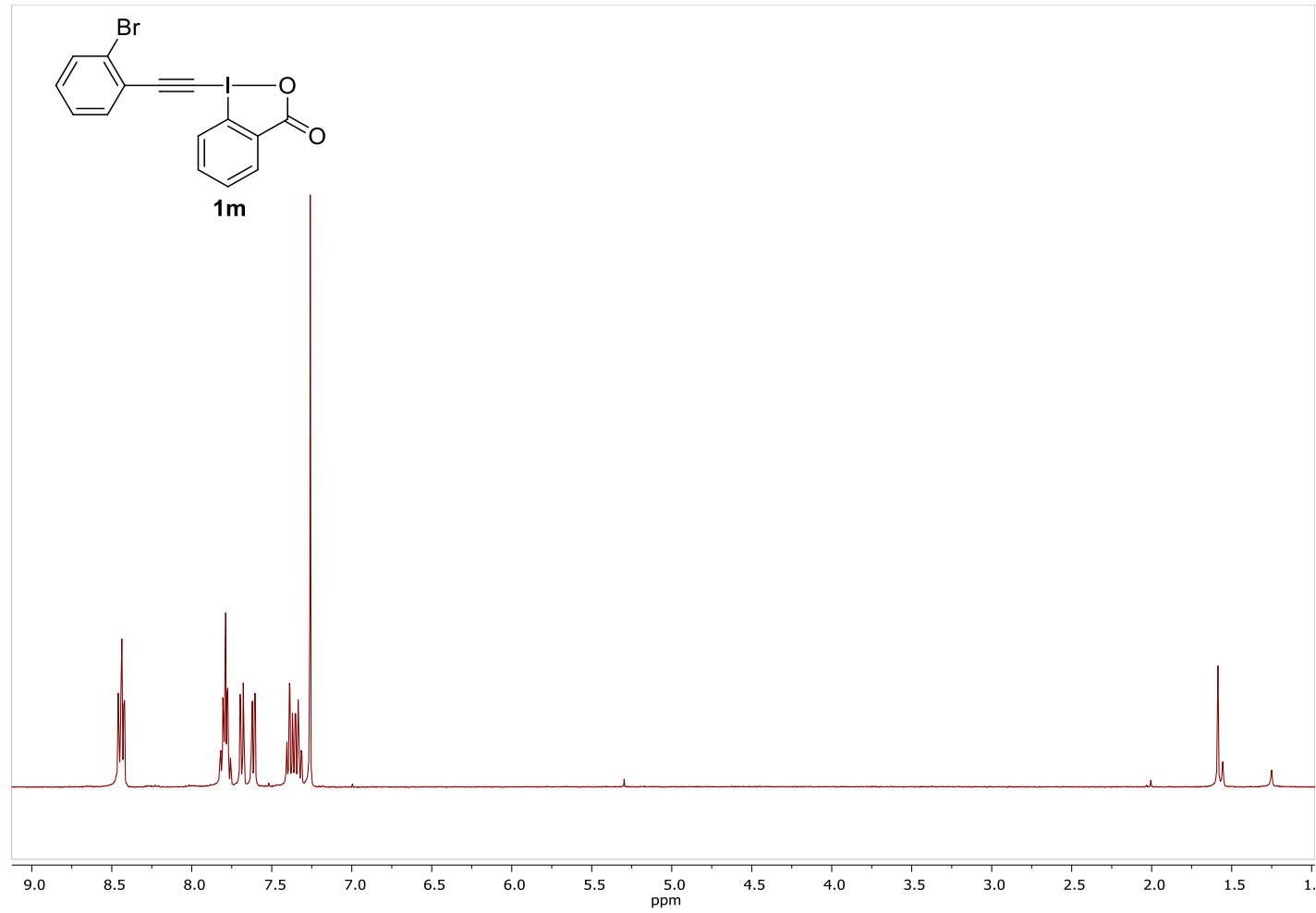

${ }^{13} \mathrm{C}-\mathrm{NMR}$ (101 MHz, CDCl3)
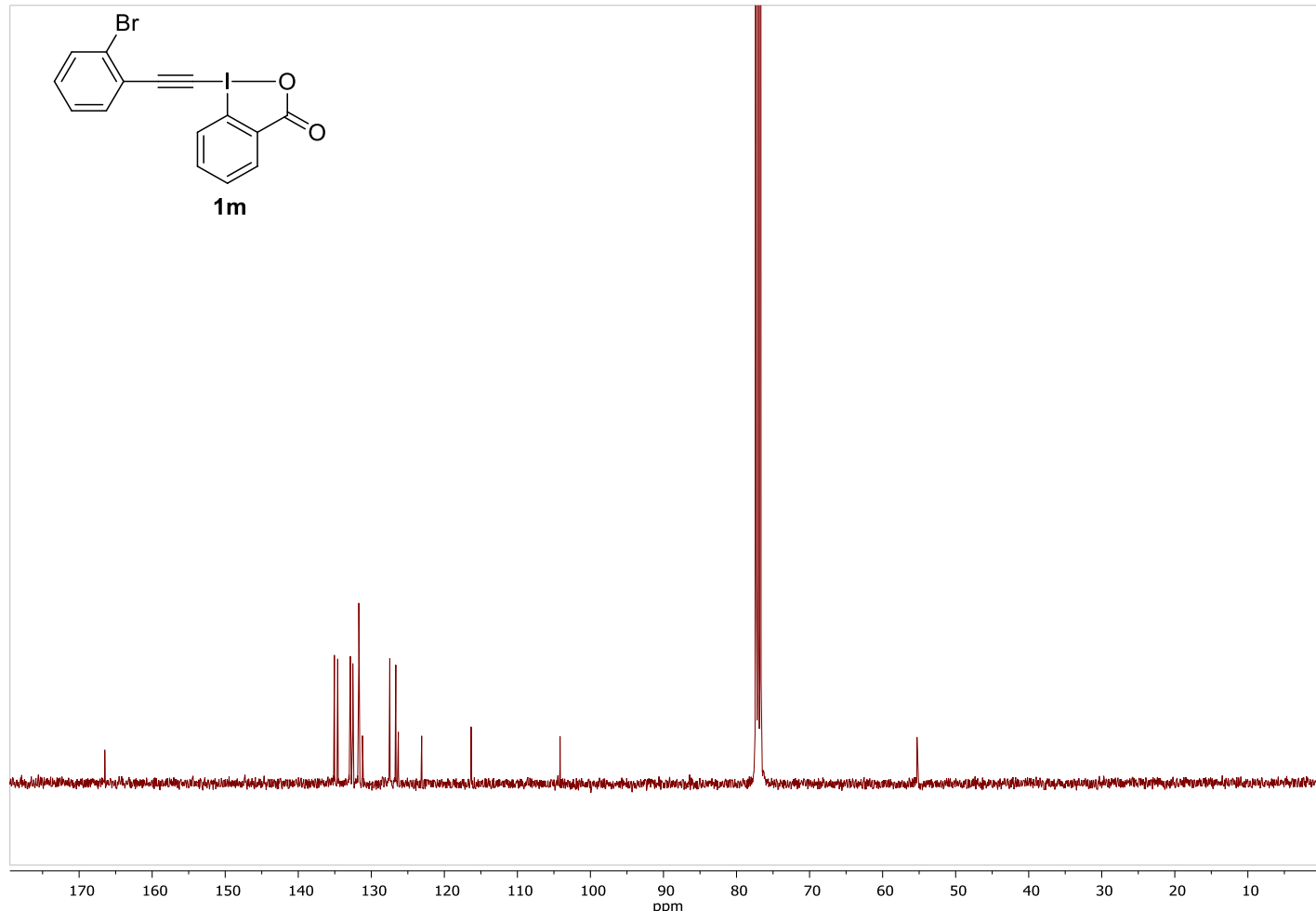

IR Spectra 


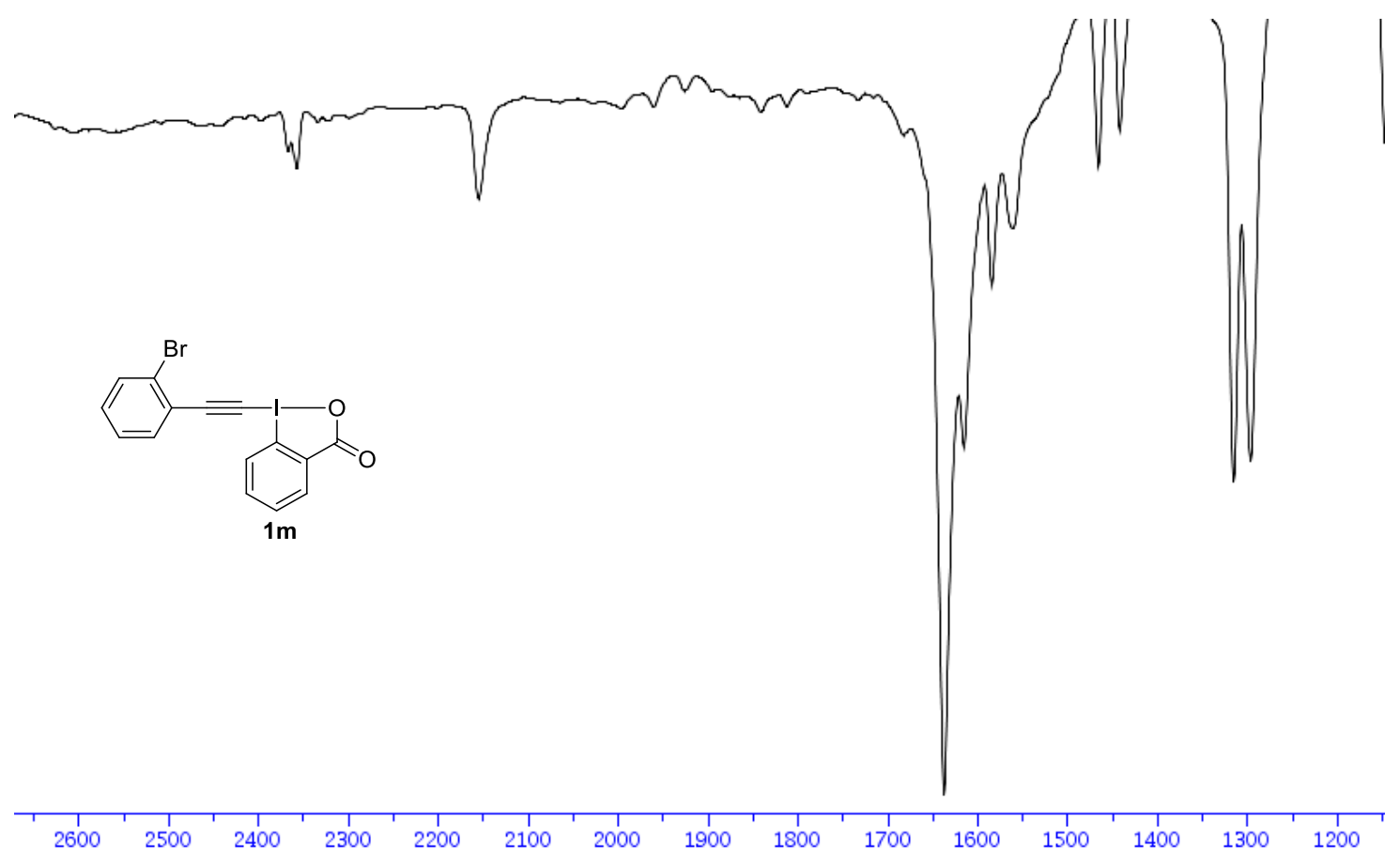


${ }^{1}$ H-NMR (400 MHz, CDCl3)<smiles>O=C([O+])N1CCCC1C#C[In]S</smiles>
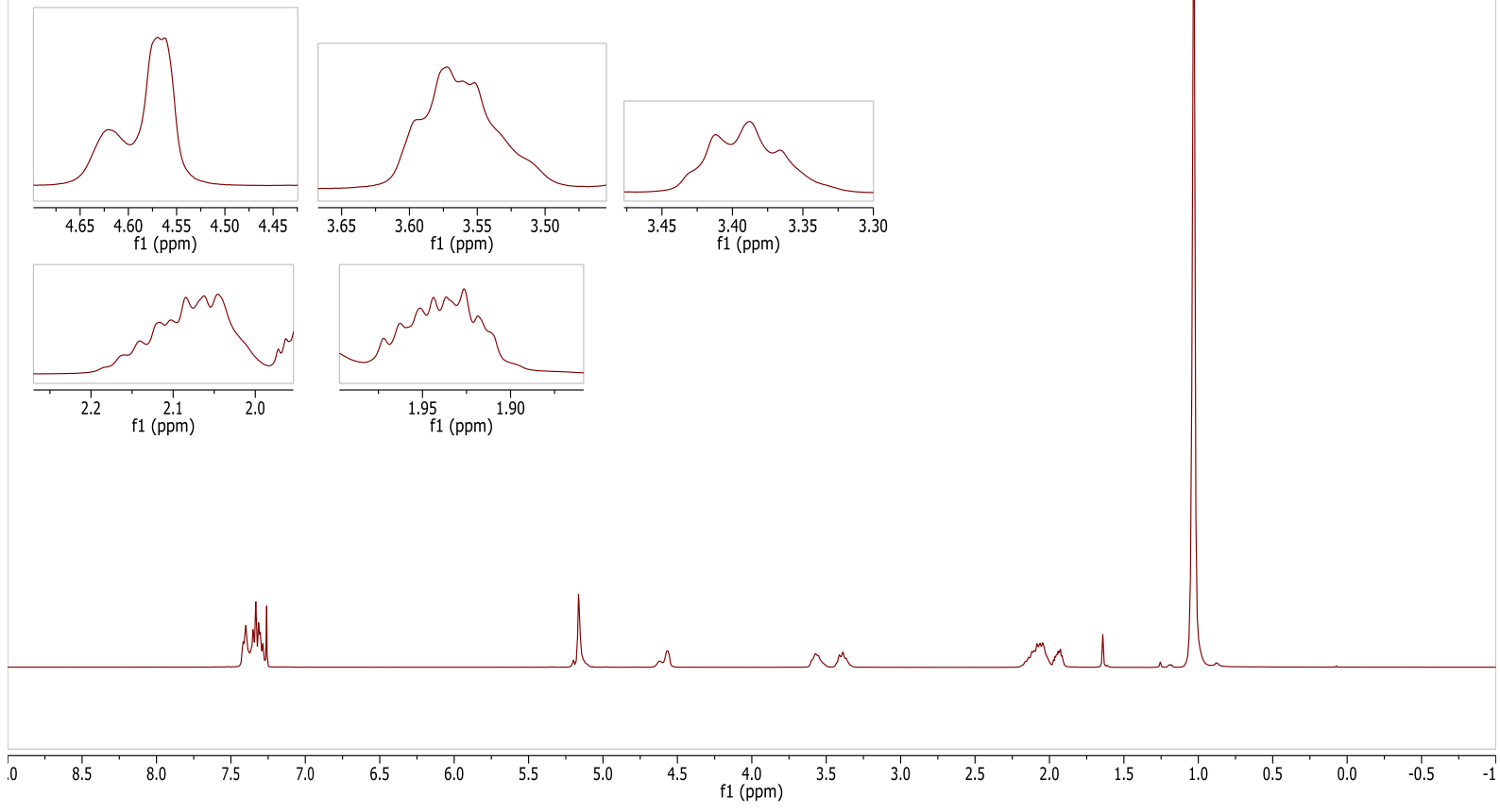

${ }^{13} \mathrm{C}-\mathrm{NMR}$ (101 MHz, CDCl3)

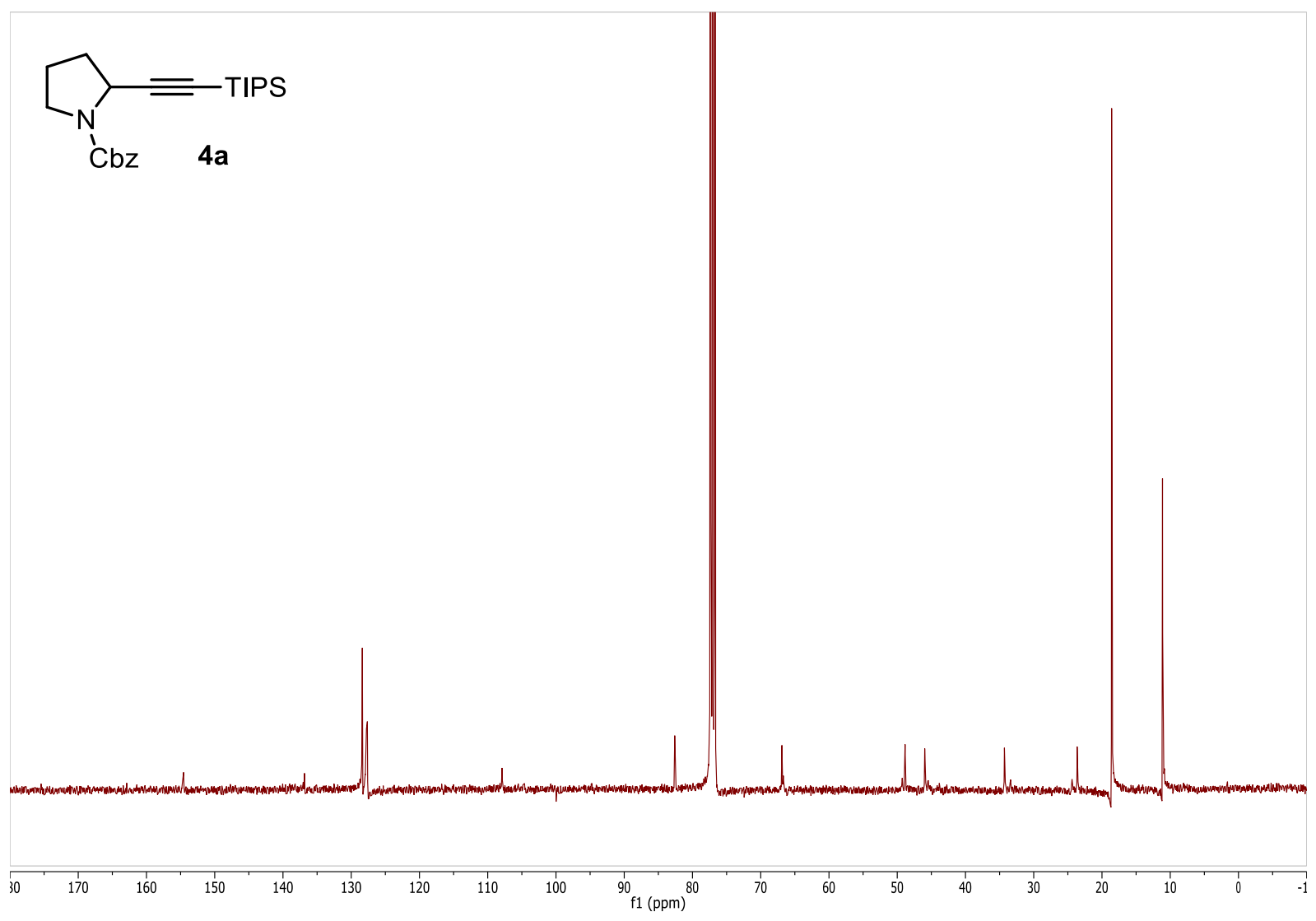

S35 


\section{IR Spectra}

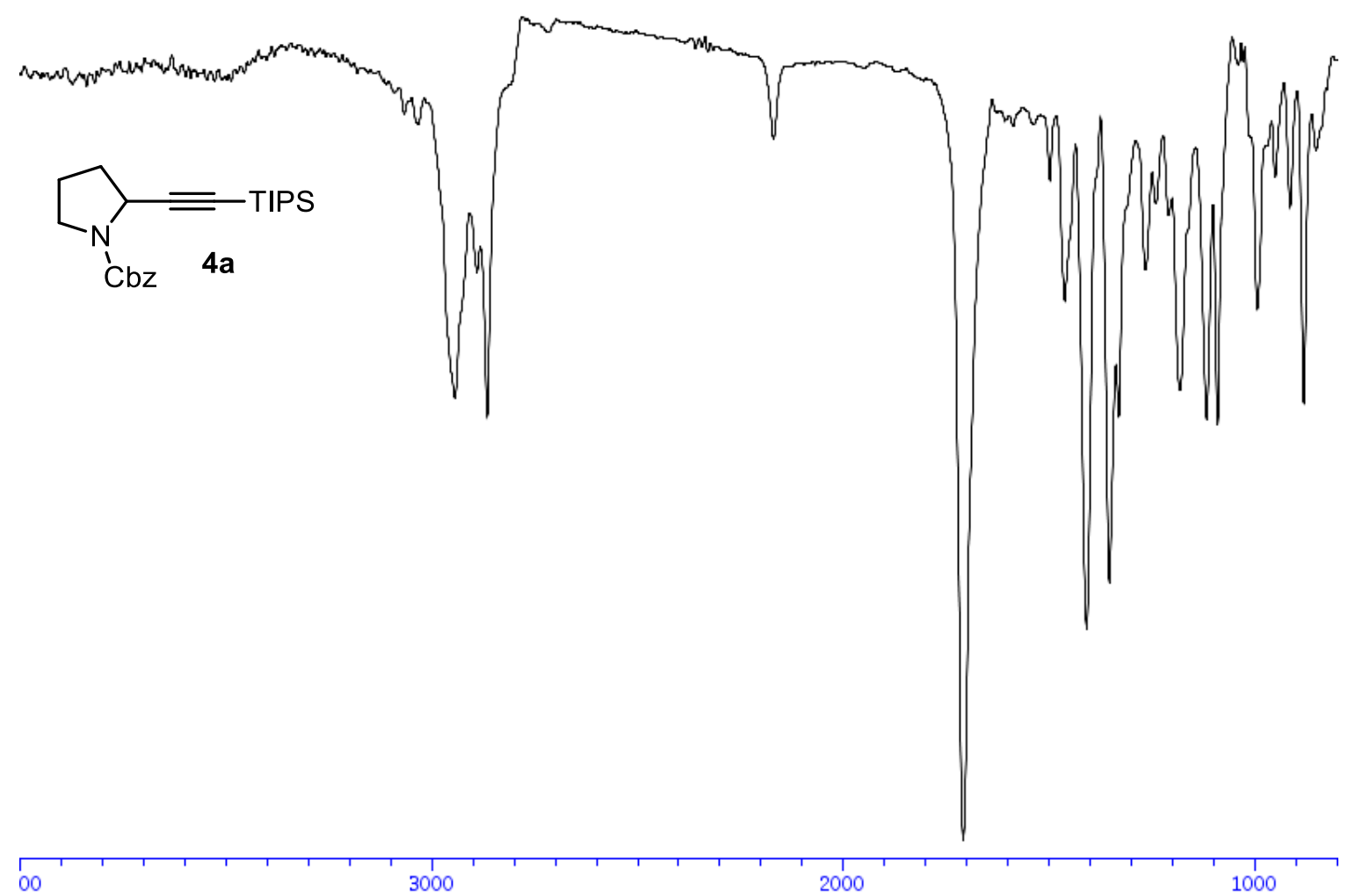


${ }^{1} \mathrm{H}-\mathrm{NMR}\left(400 \mathrm{MHz}, \mathrm{CDCl}_{3}\right)$

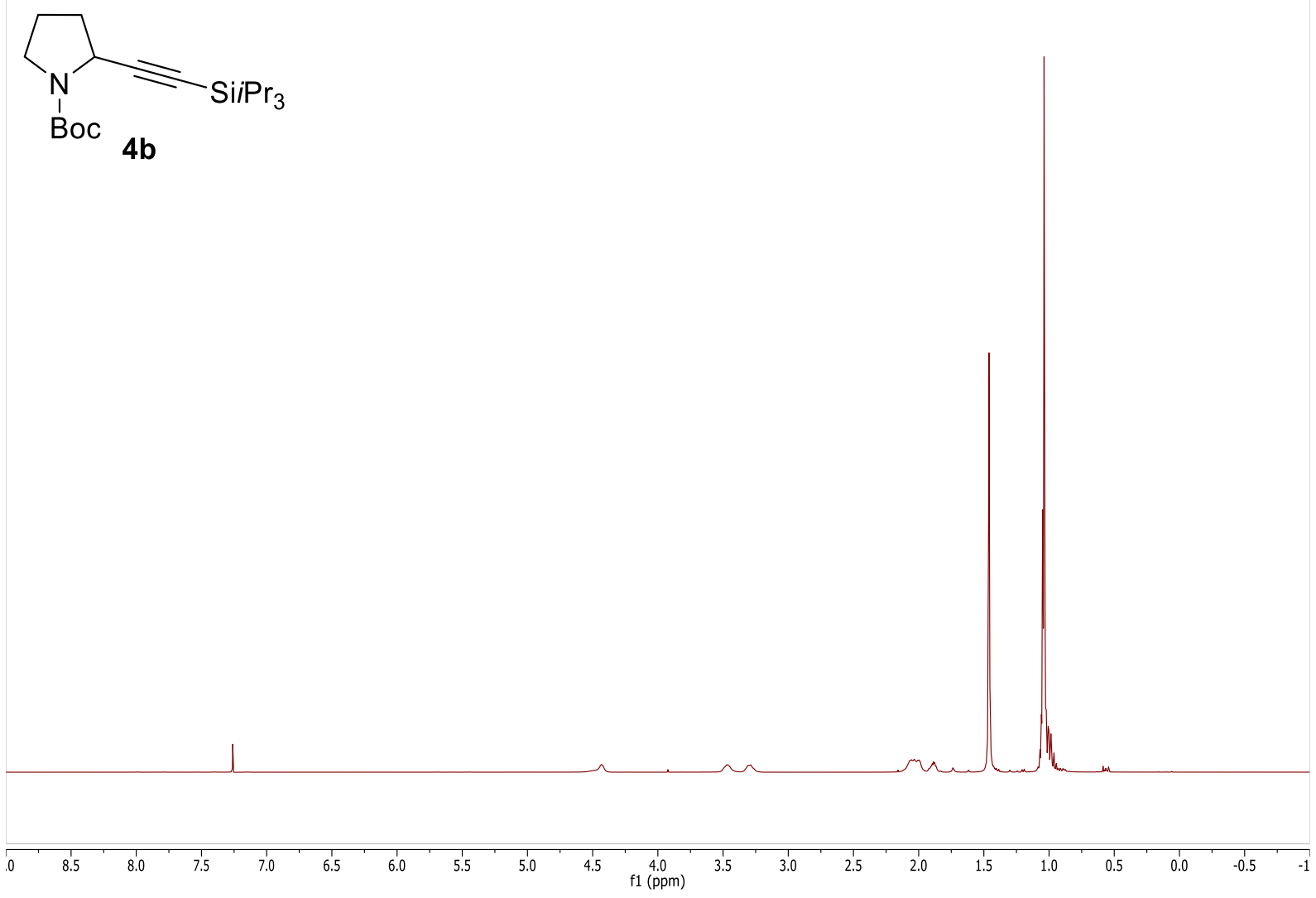

${ }^{13} \mathrm{C}$-NMR (101 MHz, $\mathrm{CDCl}_{3}$ )

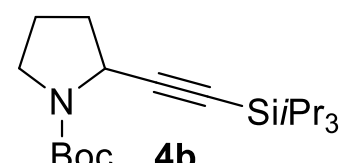

Boc 4b

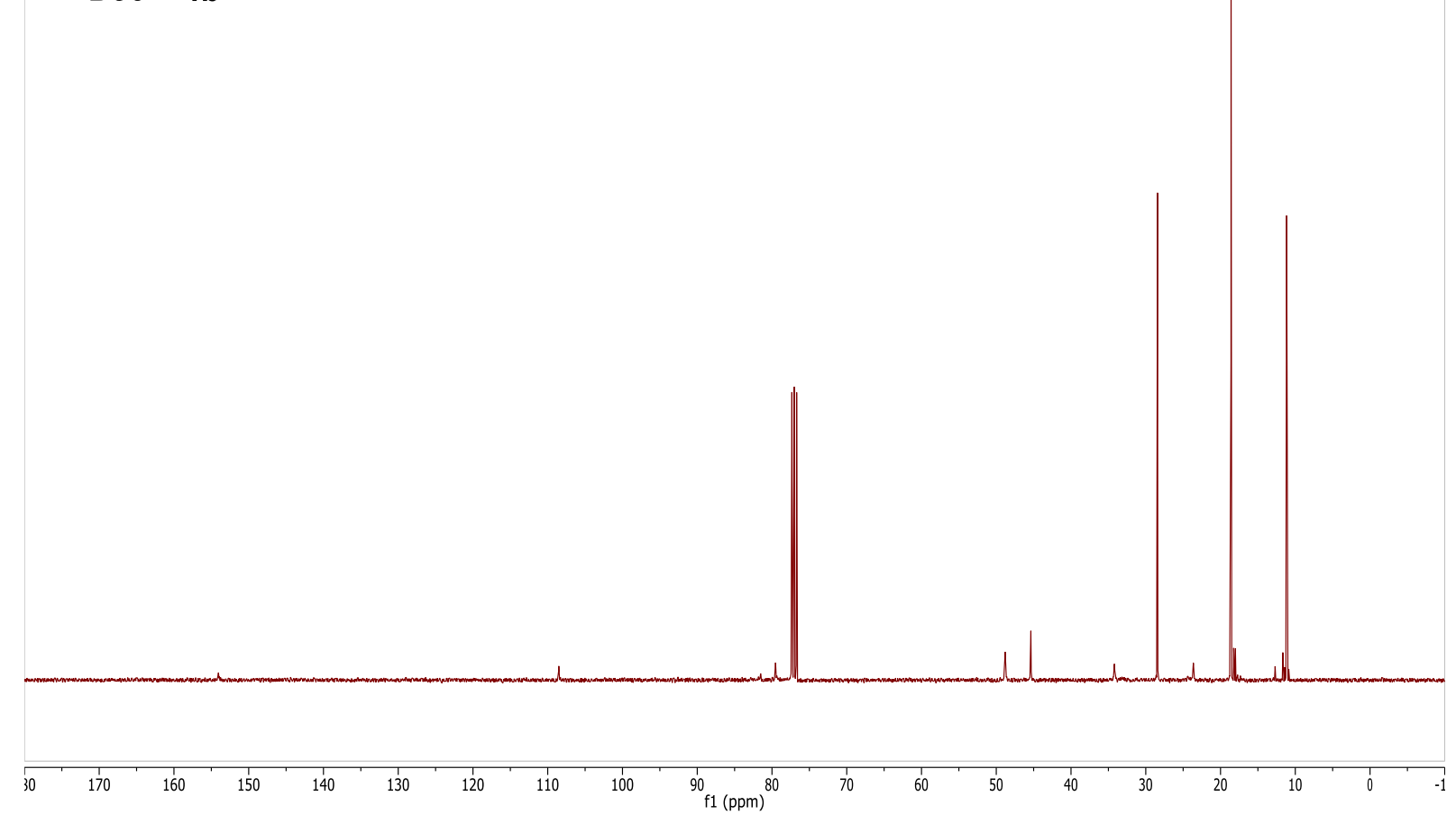




\section{IR Spectra}

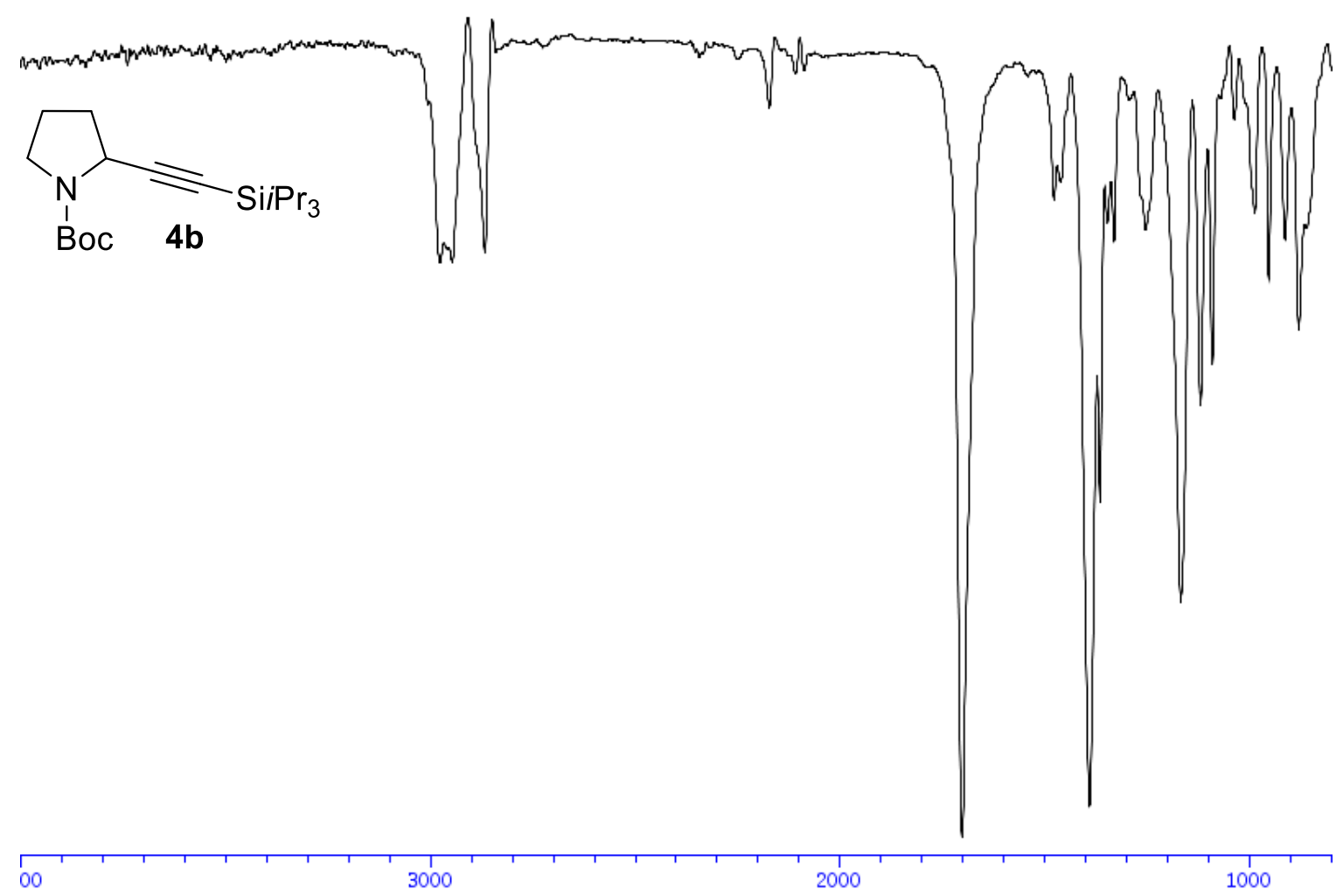


${ }^{1} \mathrm{H}-\mathrm{NMR}$ (400 MHz, CDCl3)
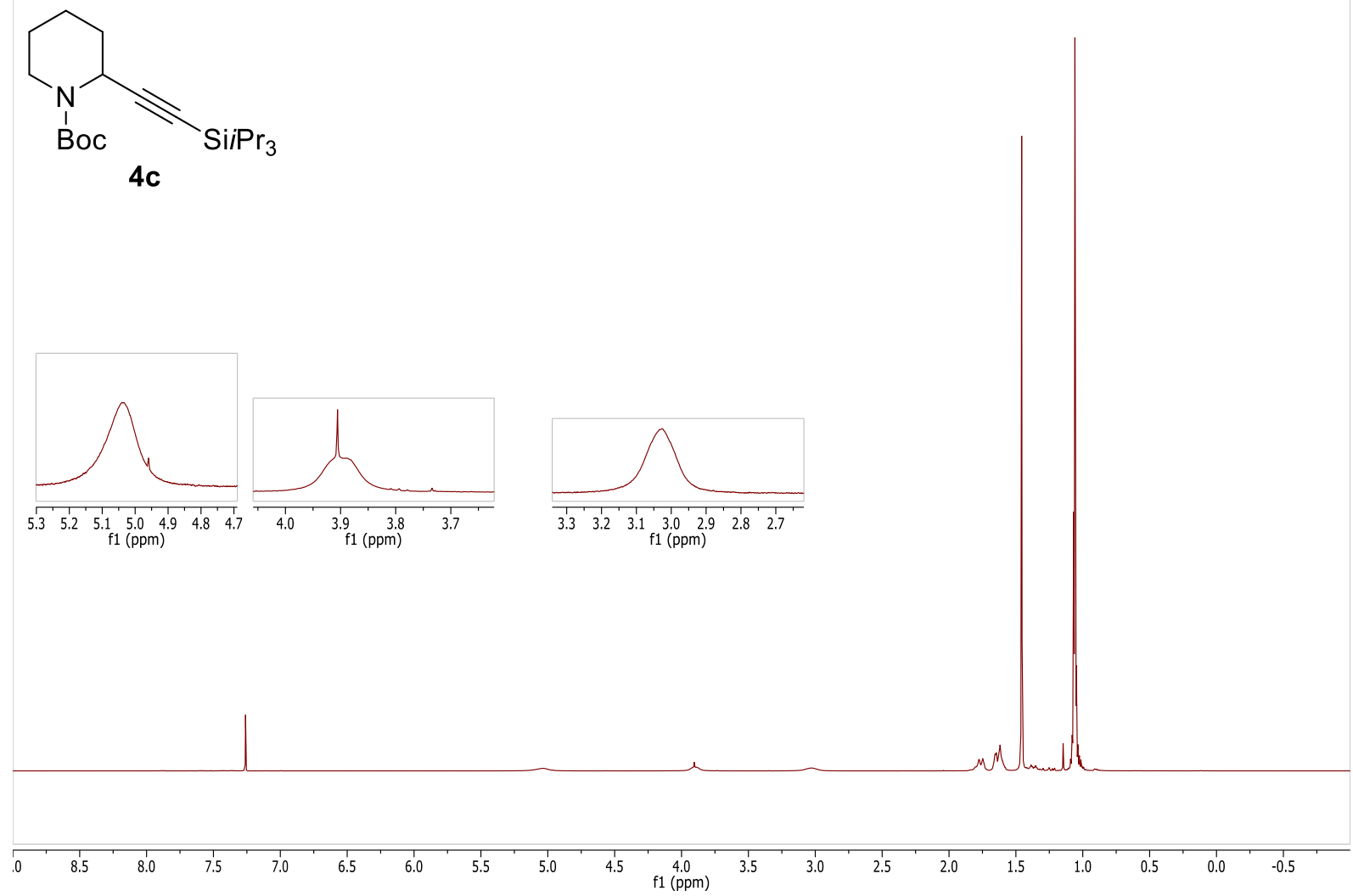

${ }^{13} \mathrm{C}-\mathrm{NMR}$ (101 MHz, CDCl3)

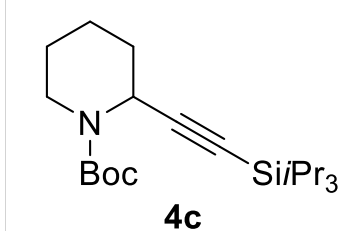

4c

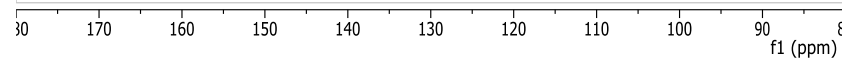




\section{IR Spectra}

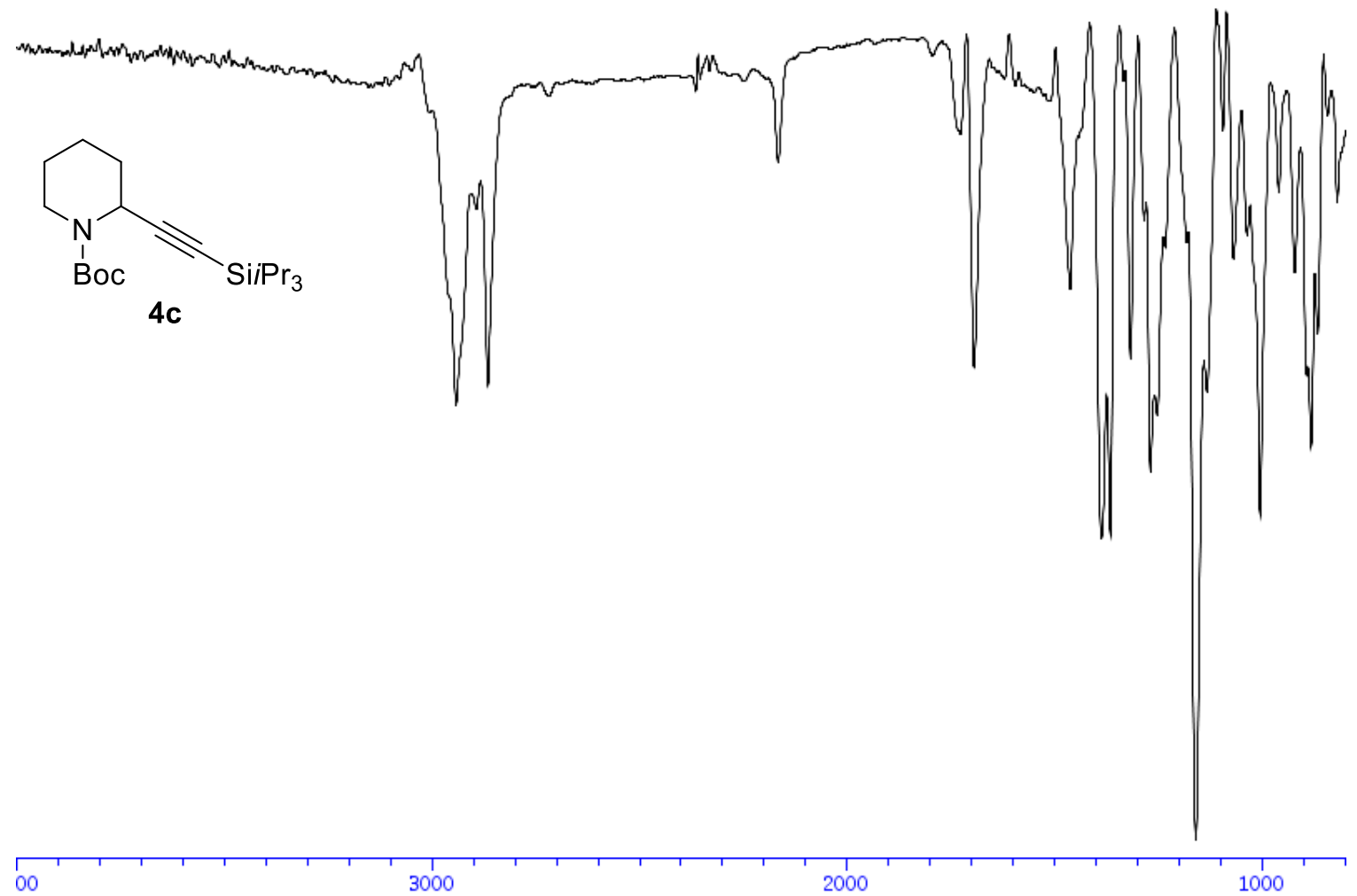


${ }^{1} \mathrm{H}-\mathrm{NMR}\left(400 \mathrm{MHz}, \mathrm{CDCl}_{3}\right)$
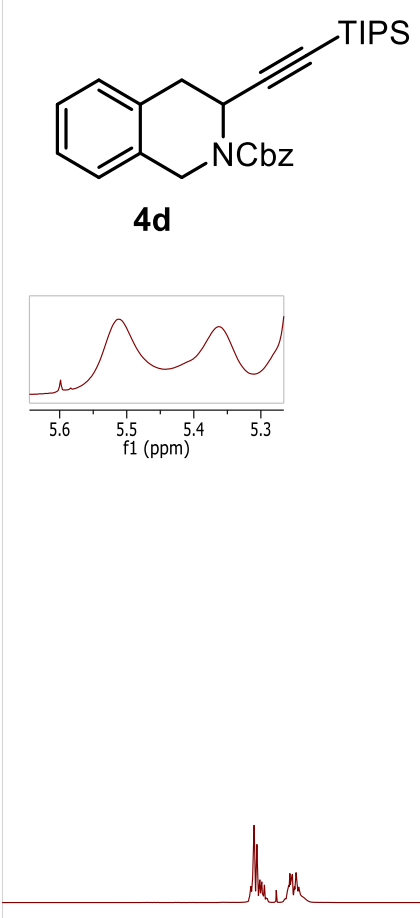
$\Lambda \mu$

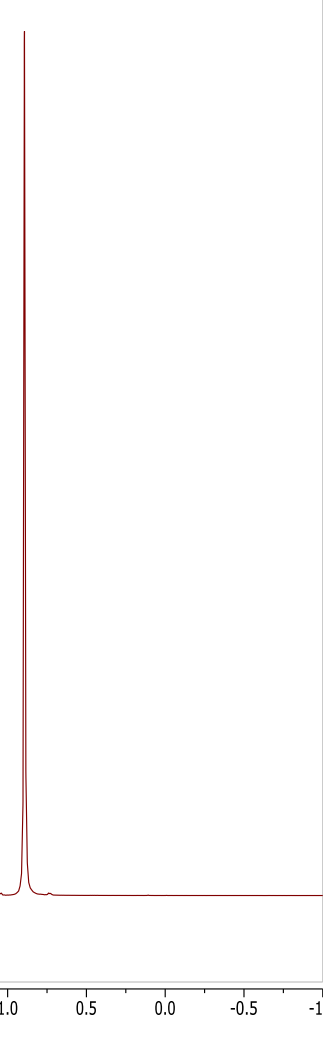

${ }^{13}$ C-NMR (101 MHz, CDCl3)
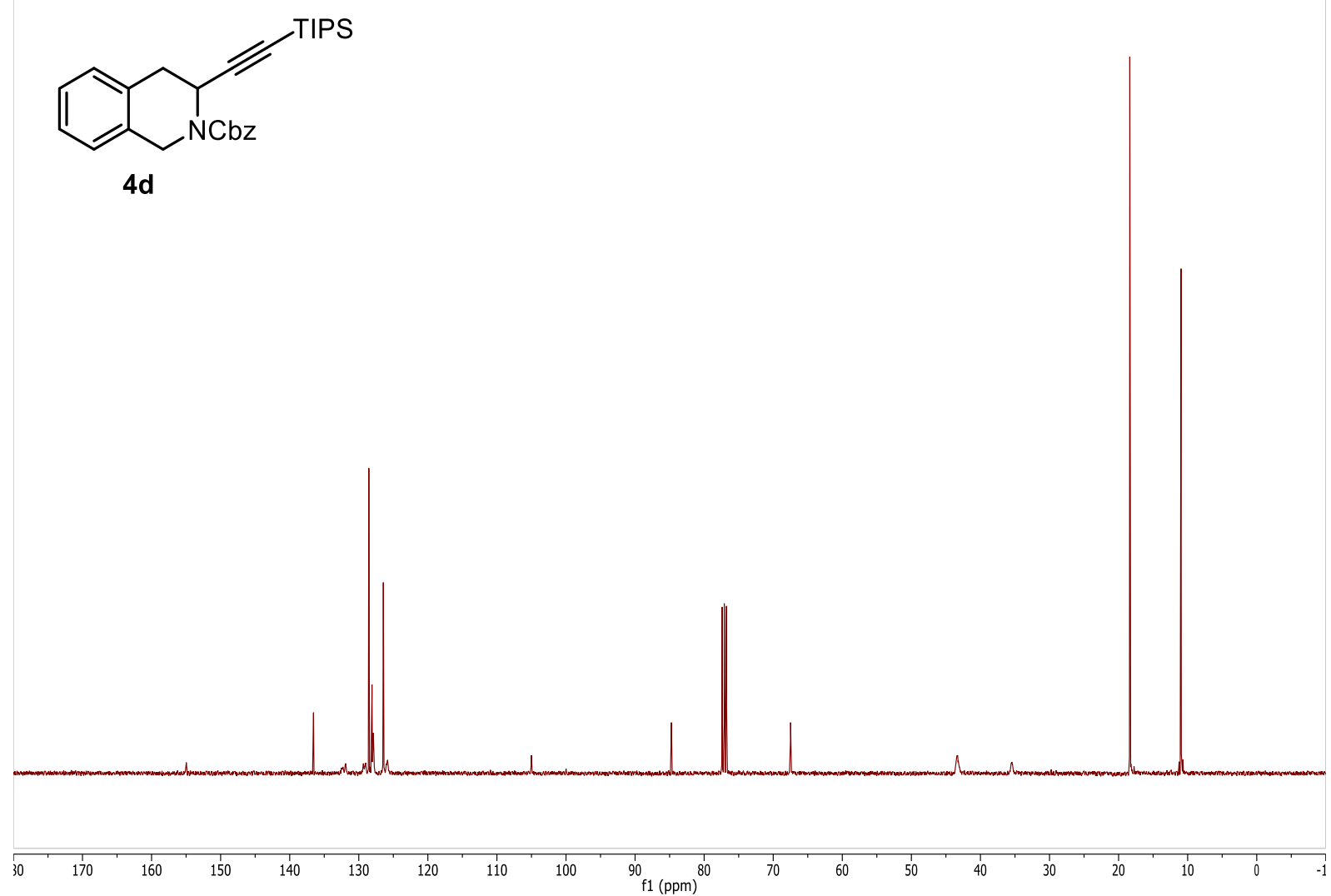


\section{IR Spectra}

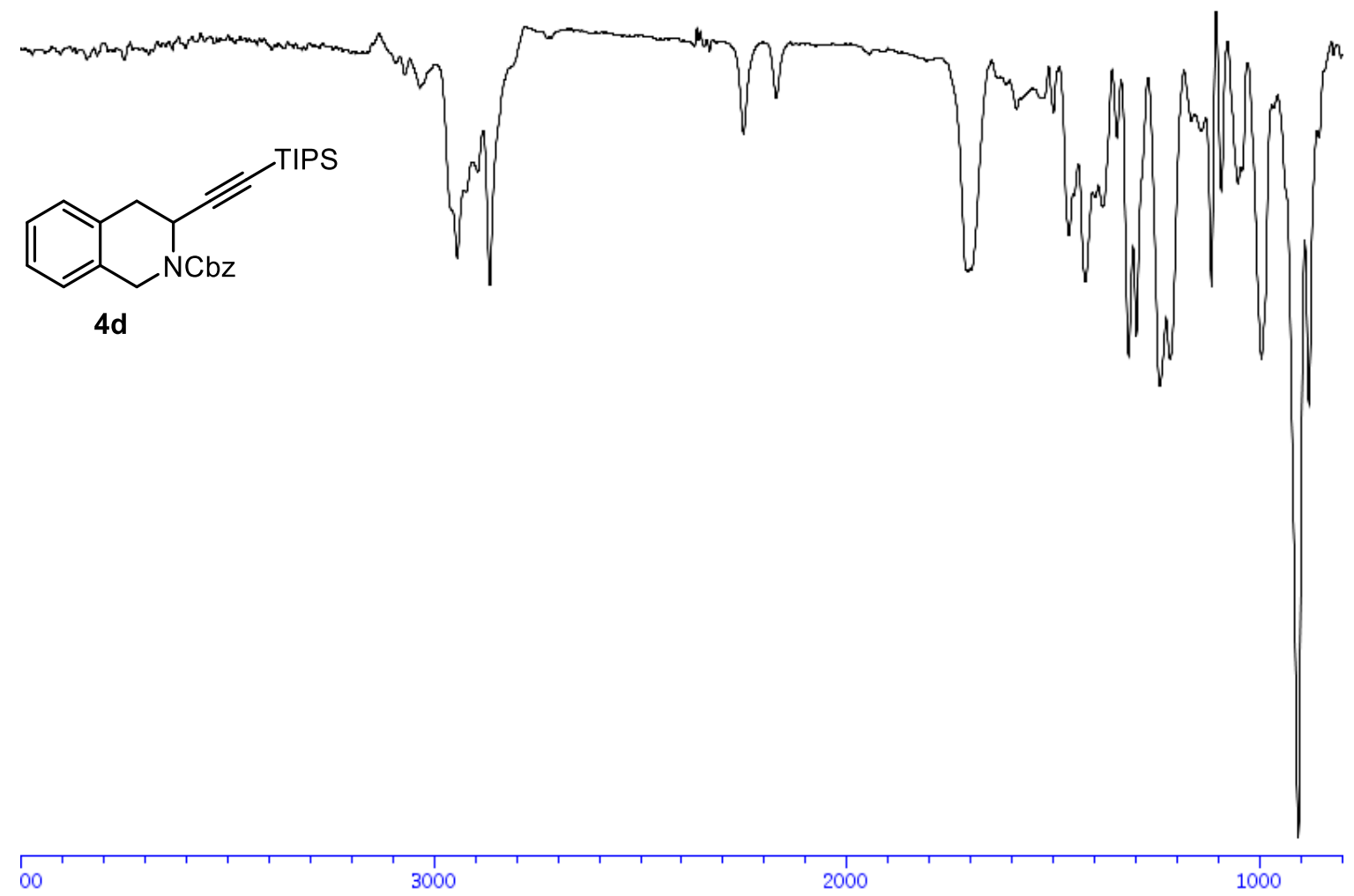


${ }^{1}$ H-NMR (400 MHz, CDCl3)

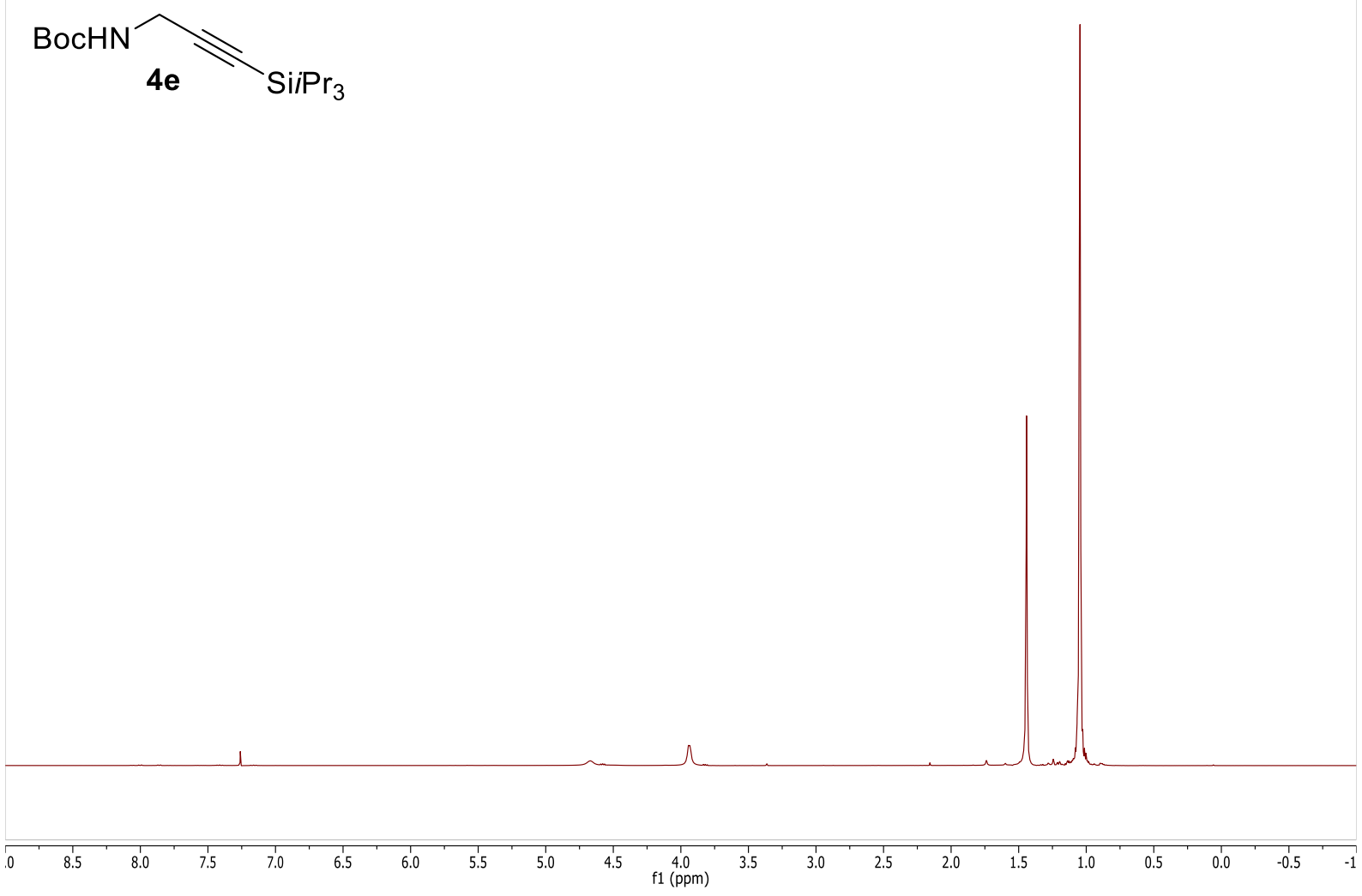

${ }^{13} \mathrm{C}-\mathrm{NMR}$ (101 MHz, CDCl3)
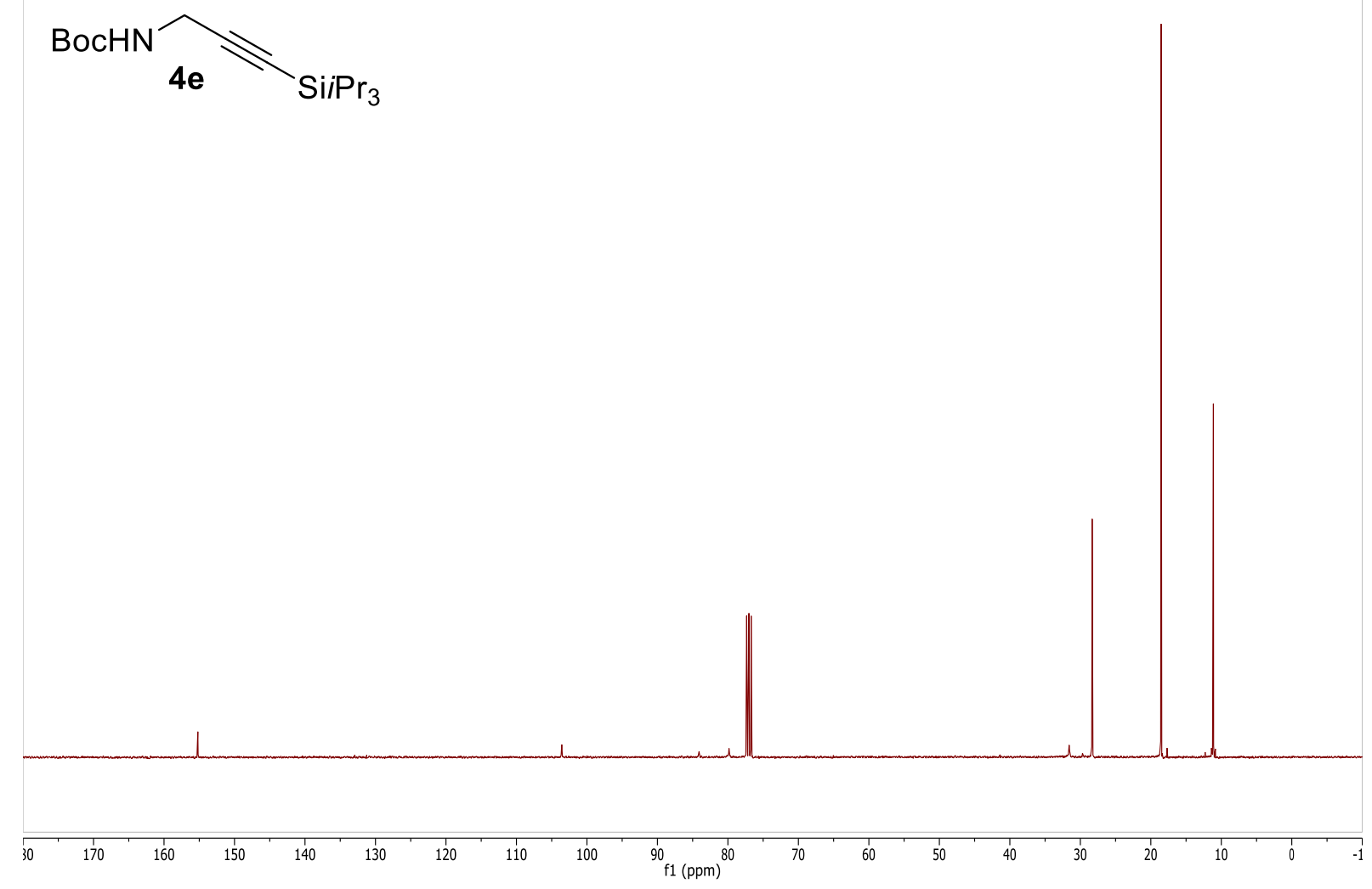


\section{IR Spectra}

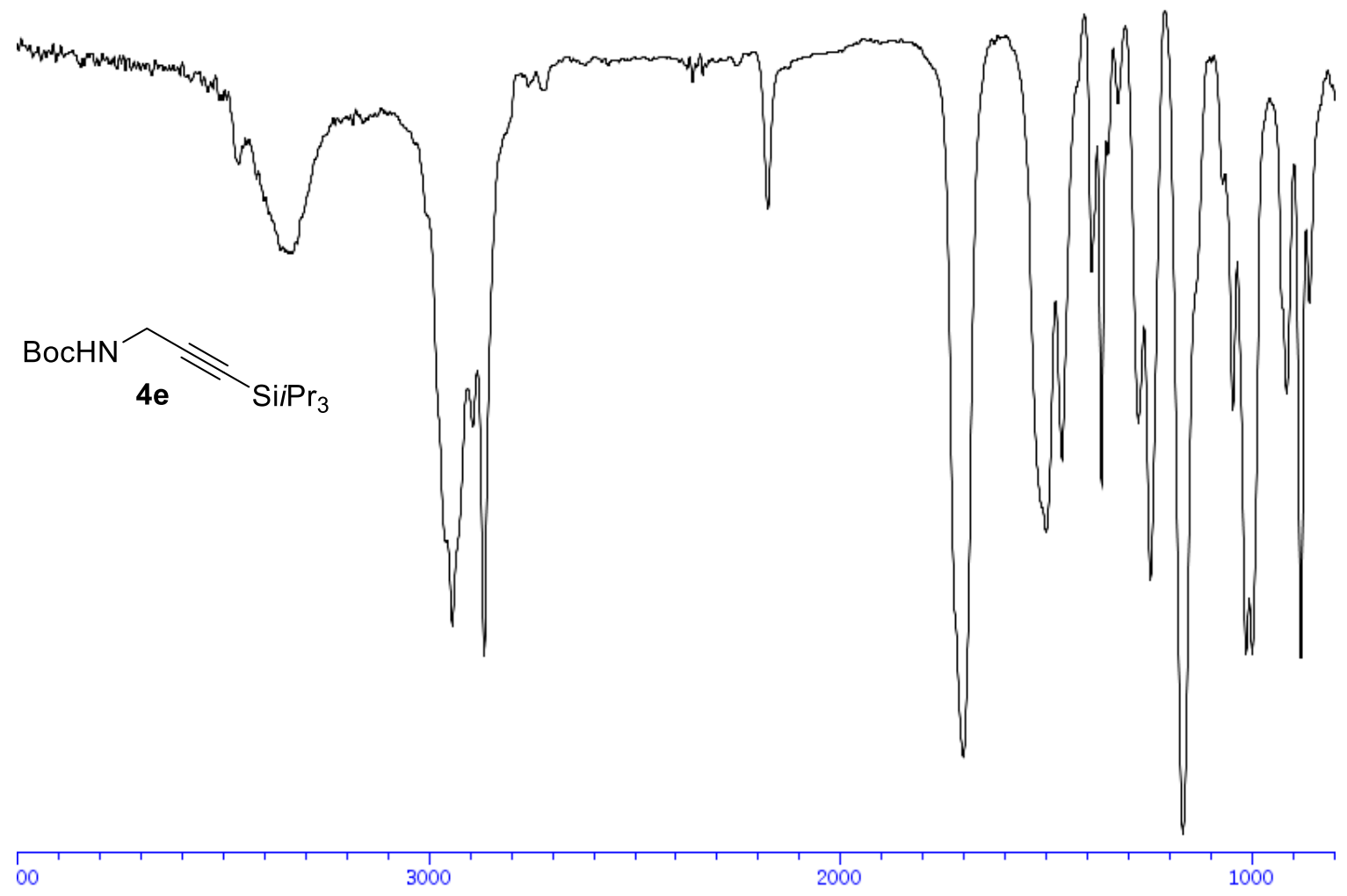


${ }^{1} \mathrm{H}-\mathrm{NMR}\left(400 \mathrm{MHz}, \mathrm{CDCl}_{3}\right)$

$\bigcap_{\mathrm{O}}=\mathrm{TIPS}$
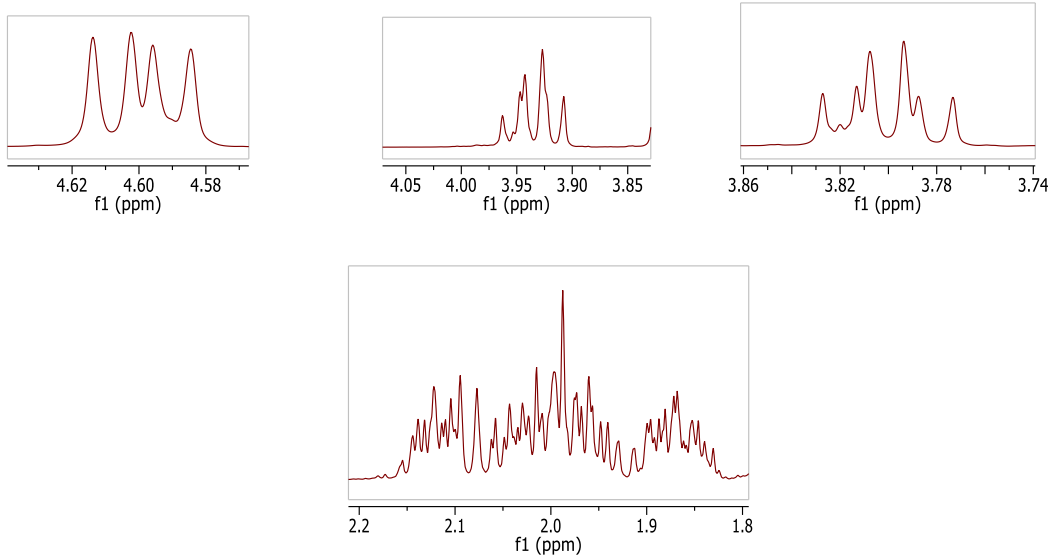

\section{and}
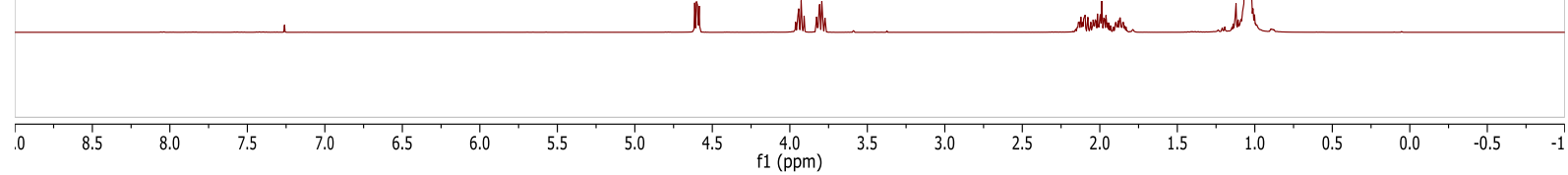

${ }^{13} \mathrm{C}$-NMR (101 MHz, $\mathrm{CDCl}_{3}$ )
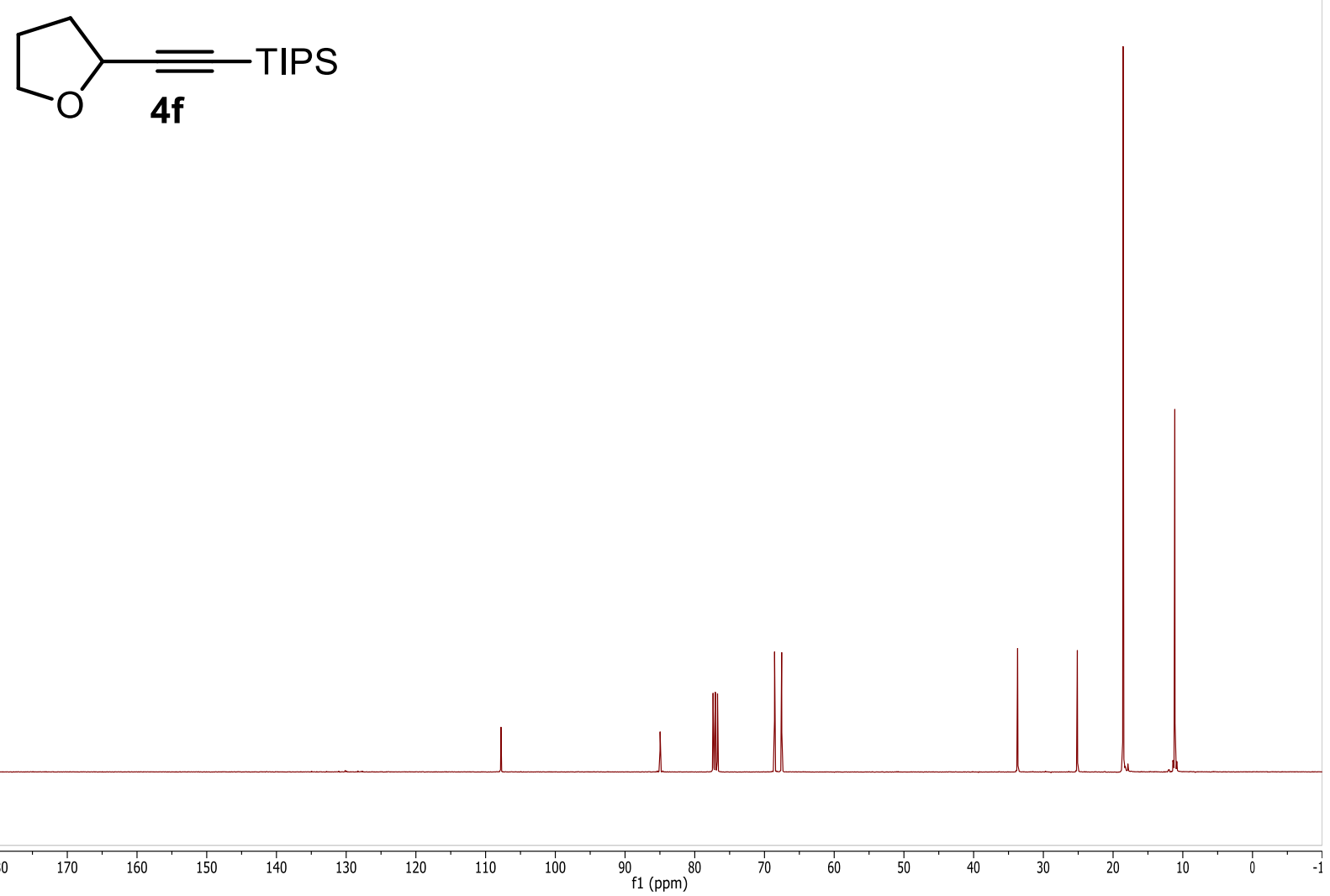


\section{IR Spectra}

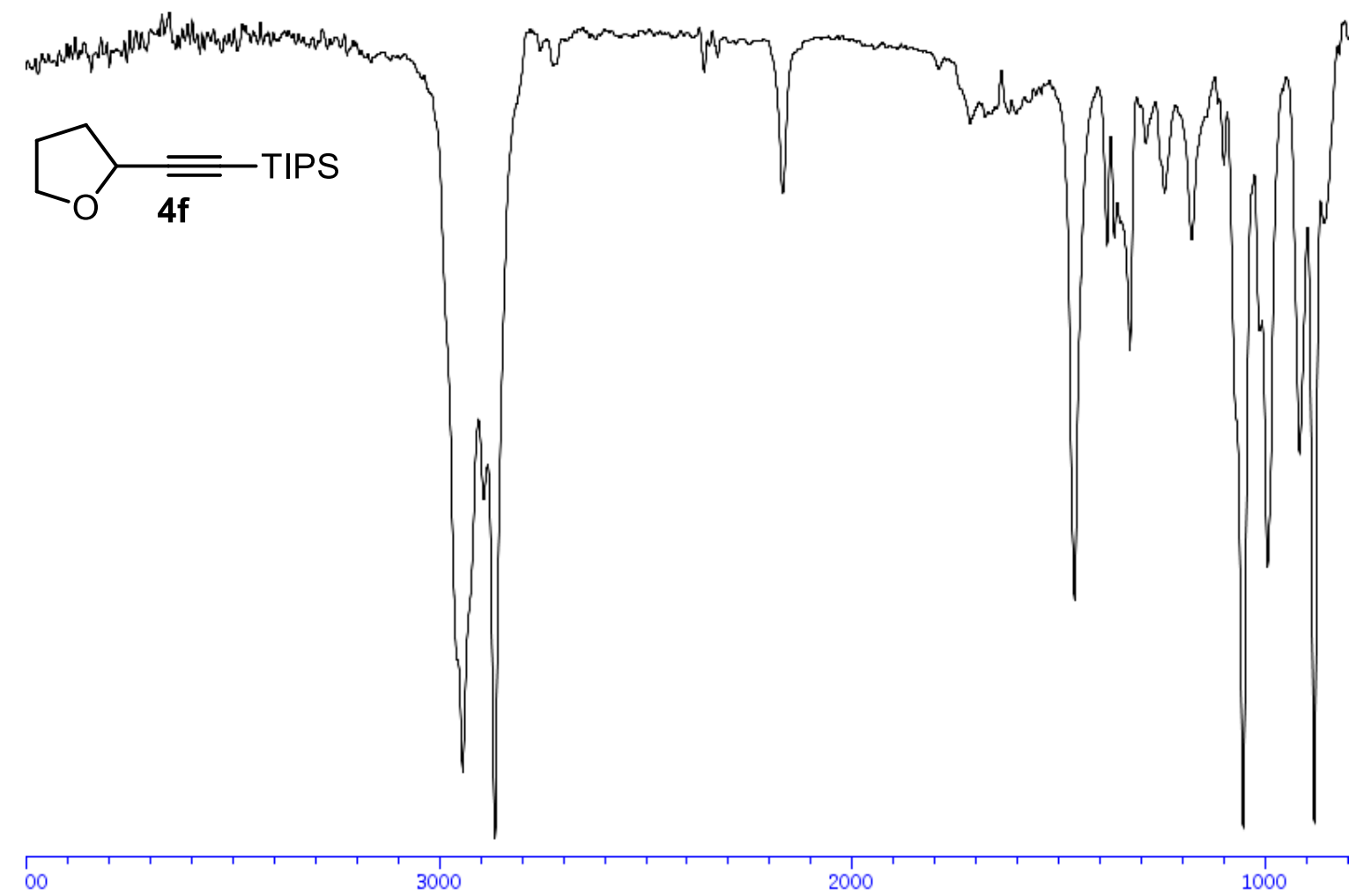


${ }^{1}$ H-NMR (400 MHz, CDCl3)

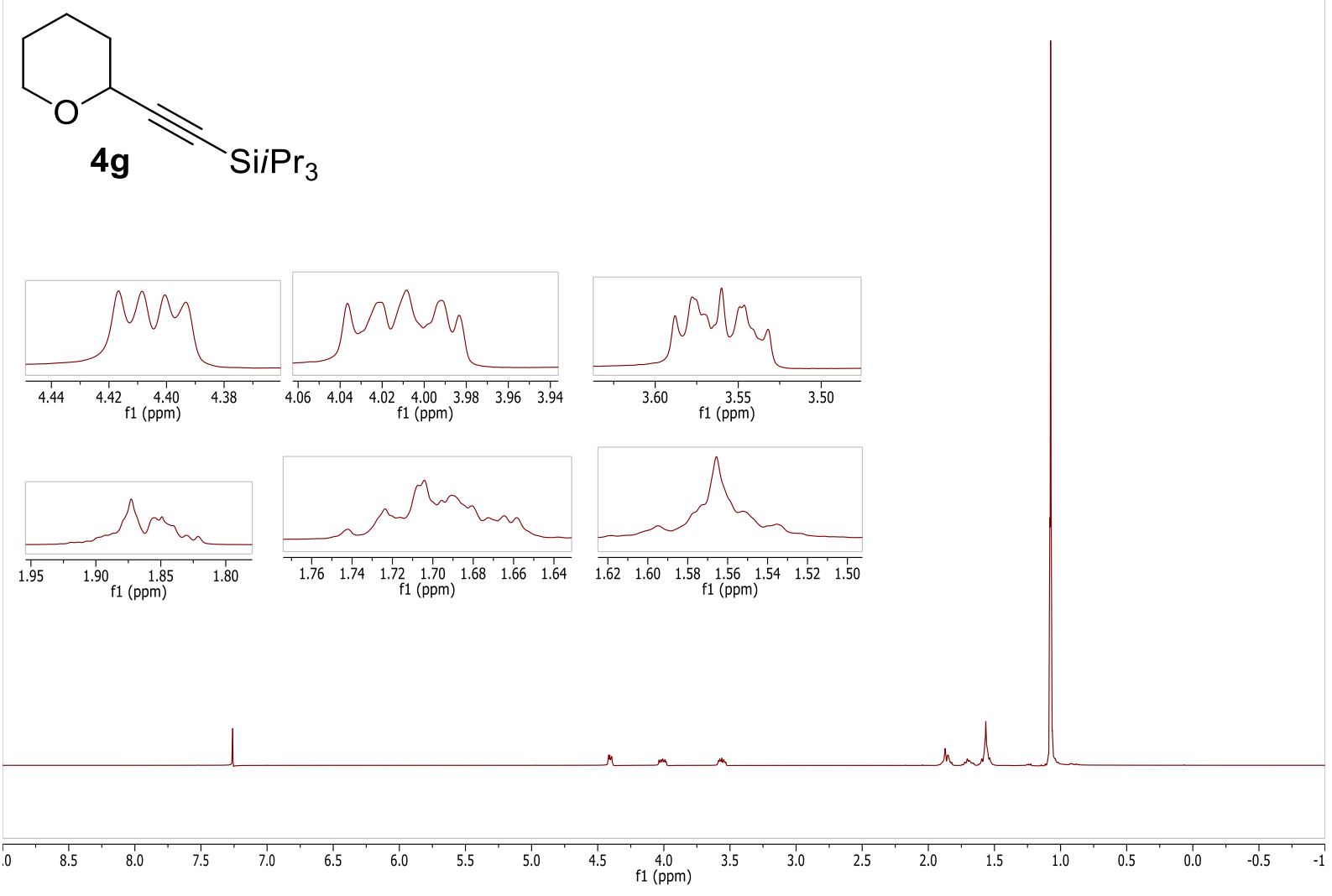

${ }^{13}$ C-NMR (101 MHz, CDCl3)<smiles>[AsH2][SiH2]C#CCC1CCCCO1</smiles>

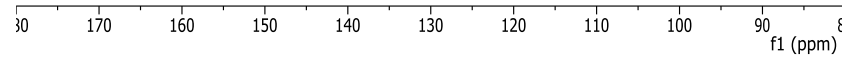




\section{IR Spectra}

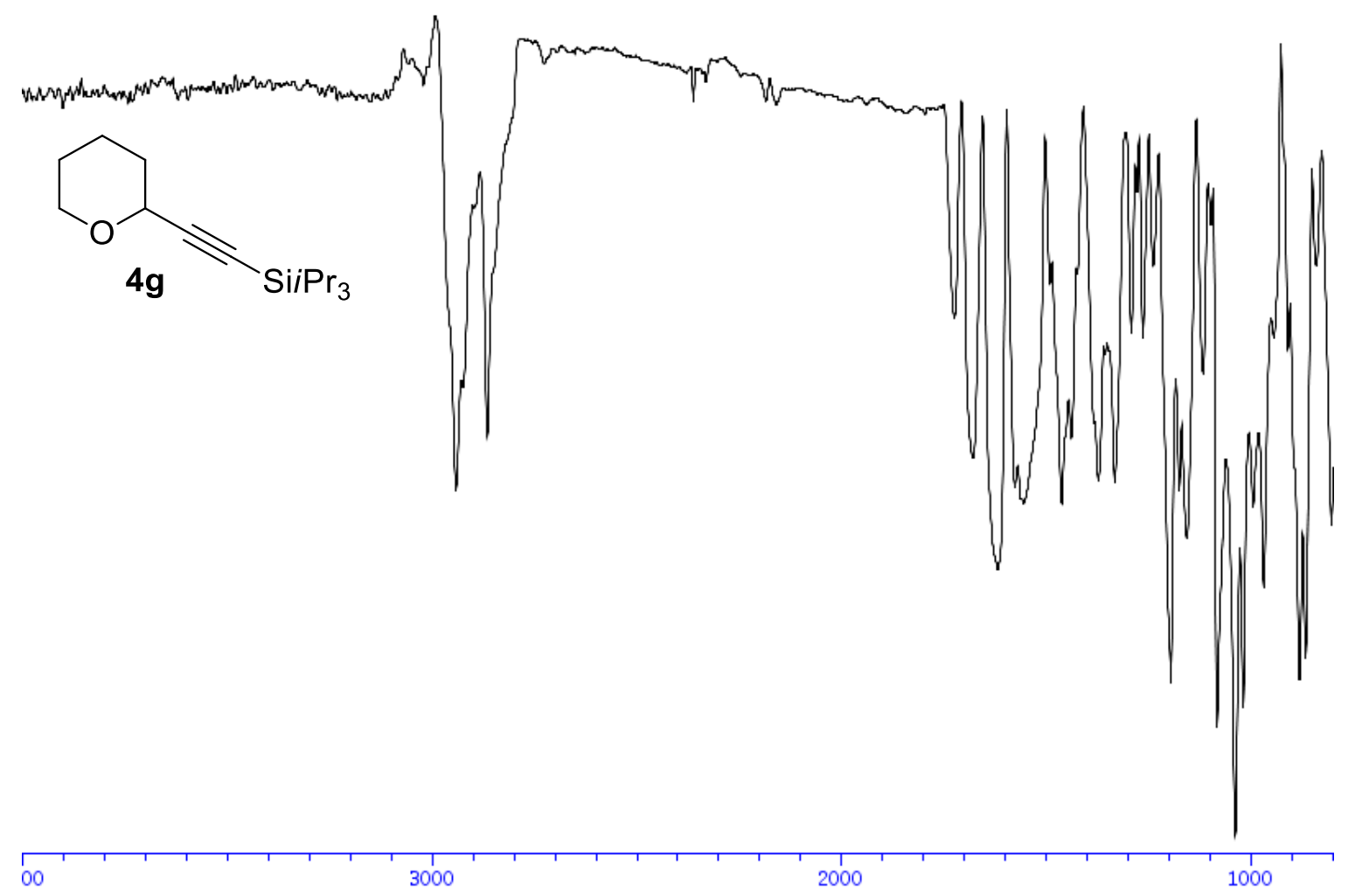


${ }^{1}$ H-NMR (400 MHz, CDCl3)

$\mathrm{Me} \sim_{\mathbf{4 h}}^{\mathrm{O}} \overbrace{}^{\mathrm{SiPr}_{3}}$
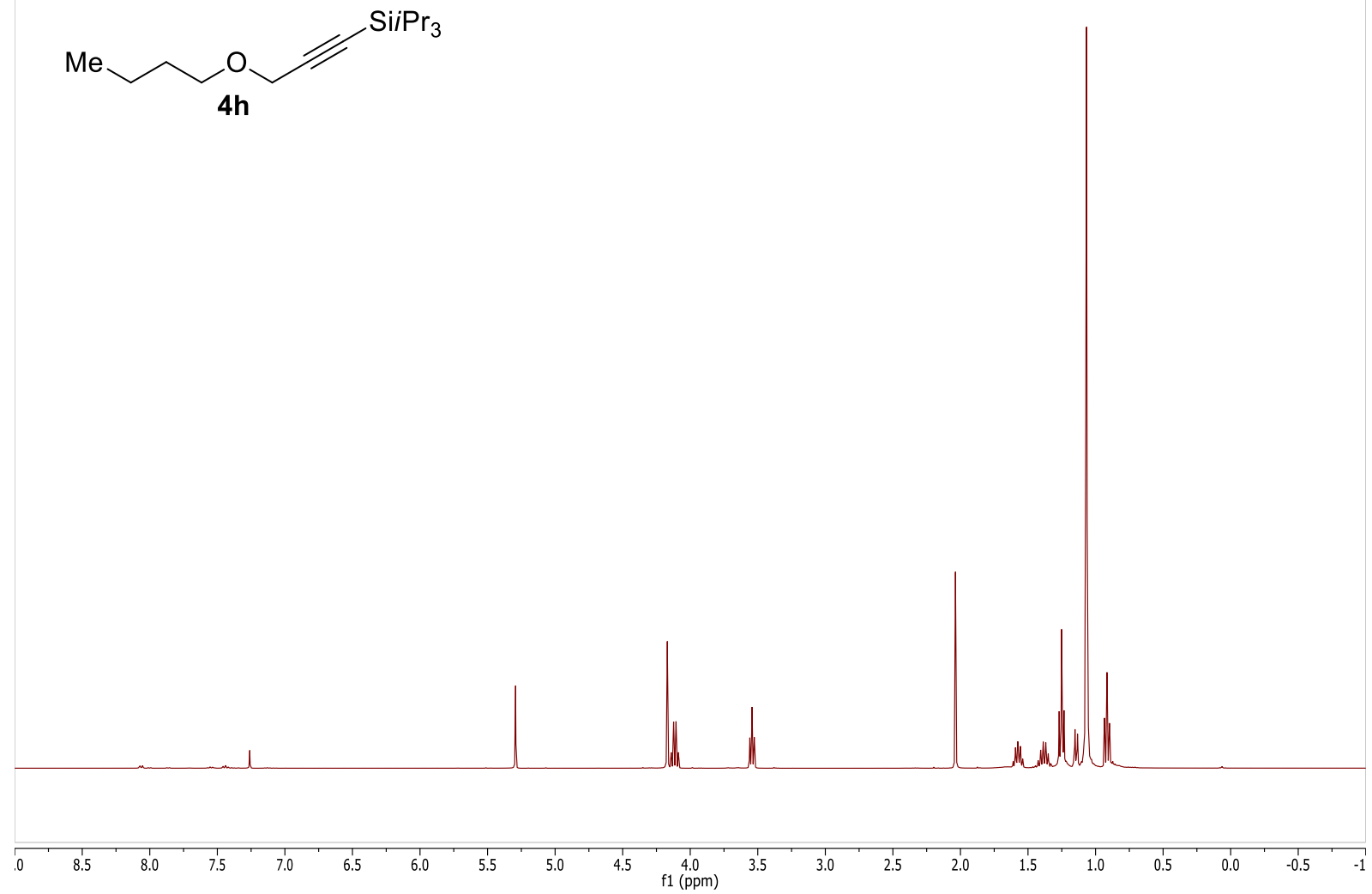

${ }^{13} \mathrm{C}-\mathrm{NMR}\left(101 \mathrm{MHz}, \mathrm{CDCl}_{3}\right)$
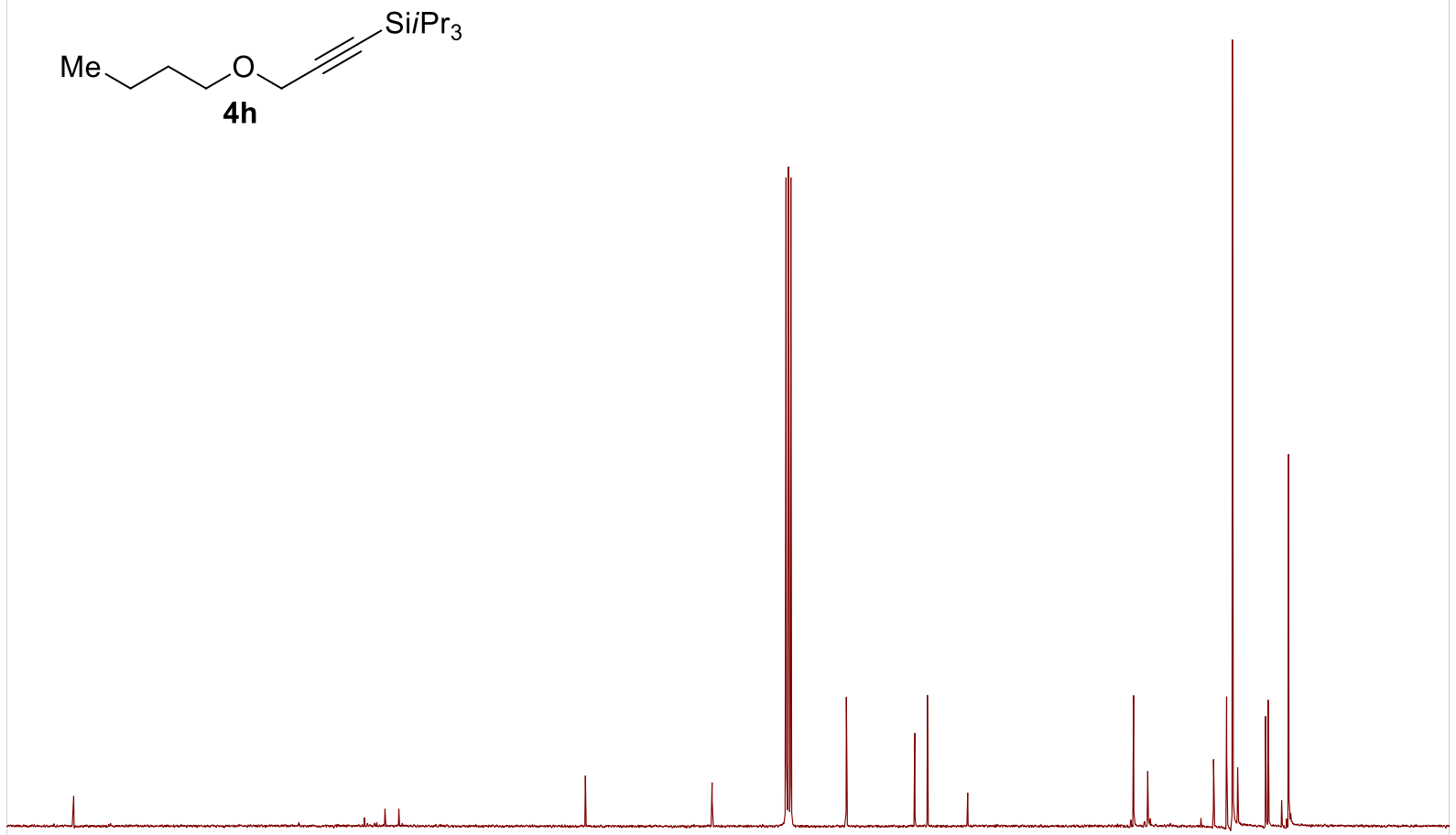

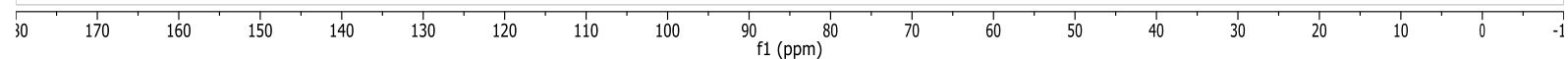




\section{IR Spectra}

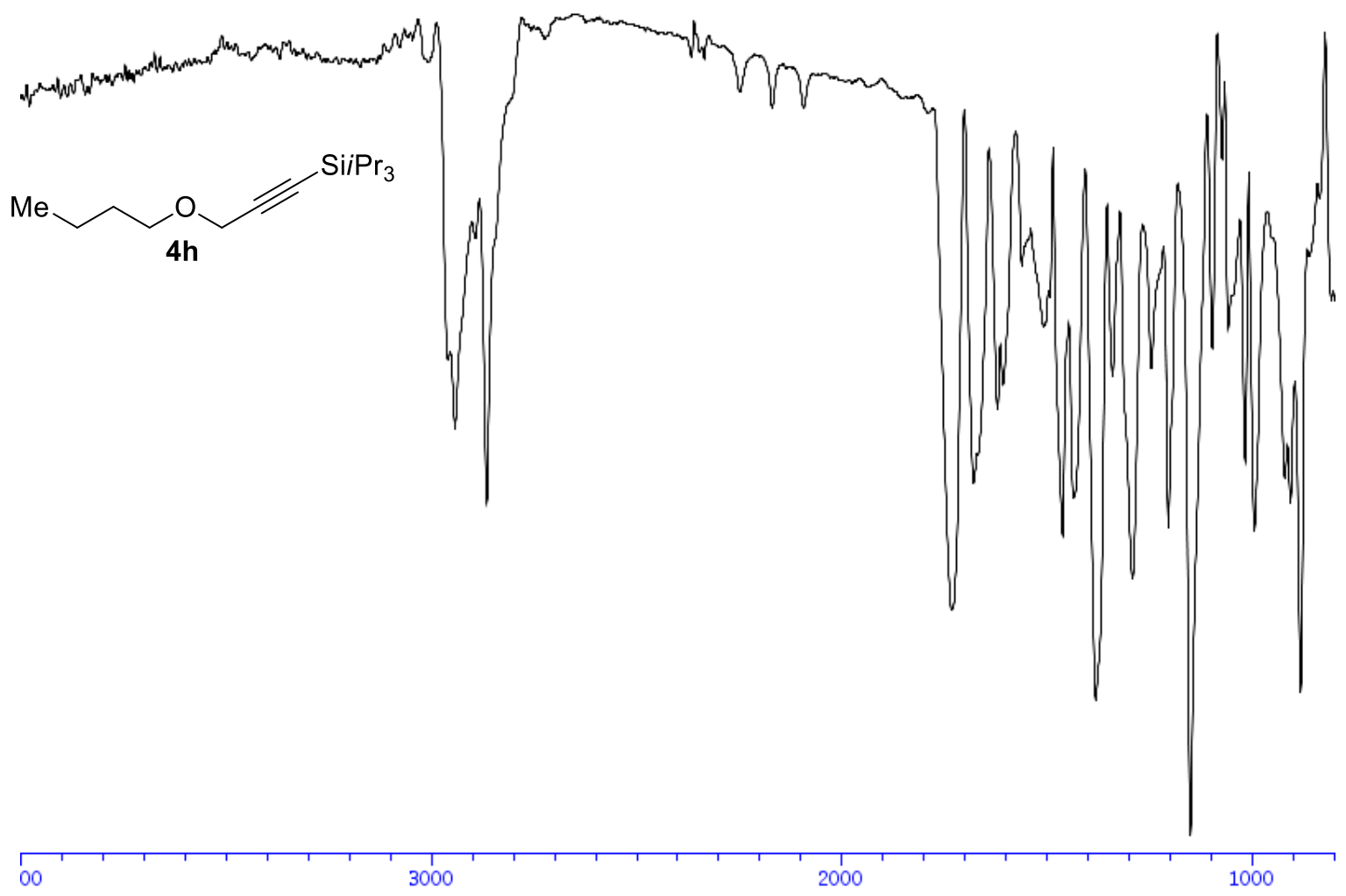


${ }^{1}$ H-NMR (400 MHz, CDCl3)

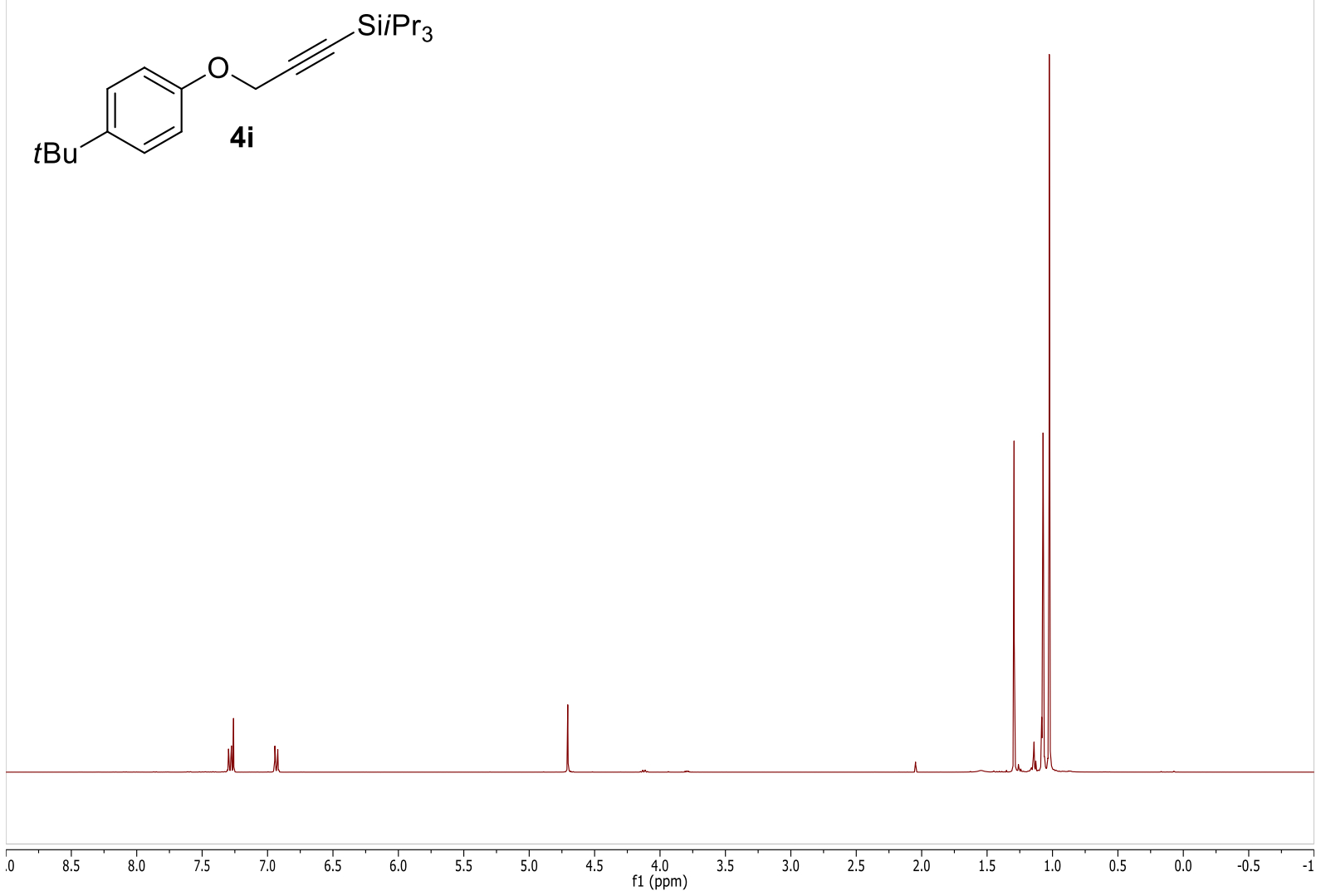

${ }^{13}$ C-NMR (101 MHz, CDCl3)

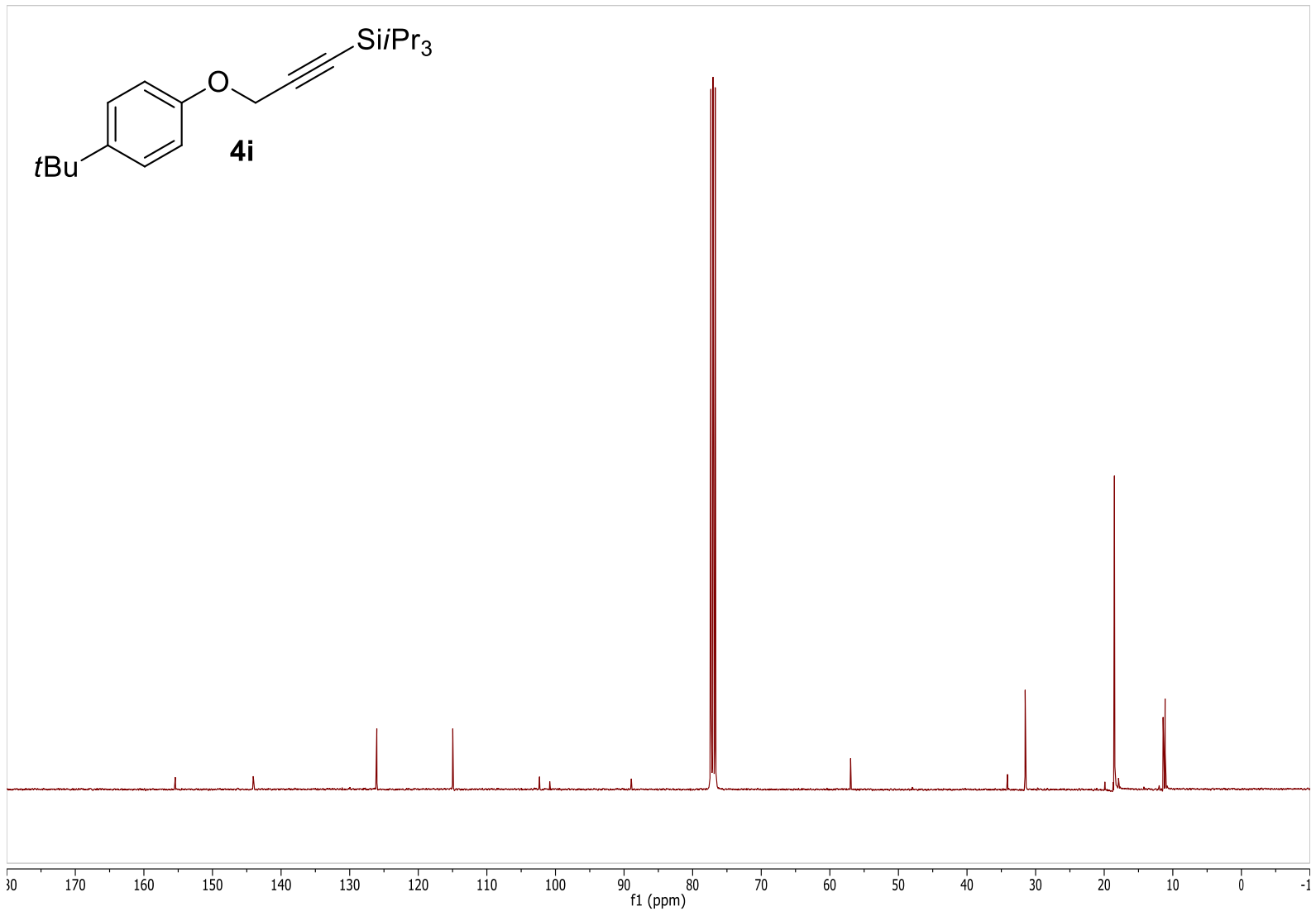




\section{IR Spectra}

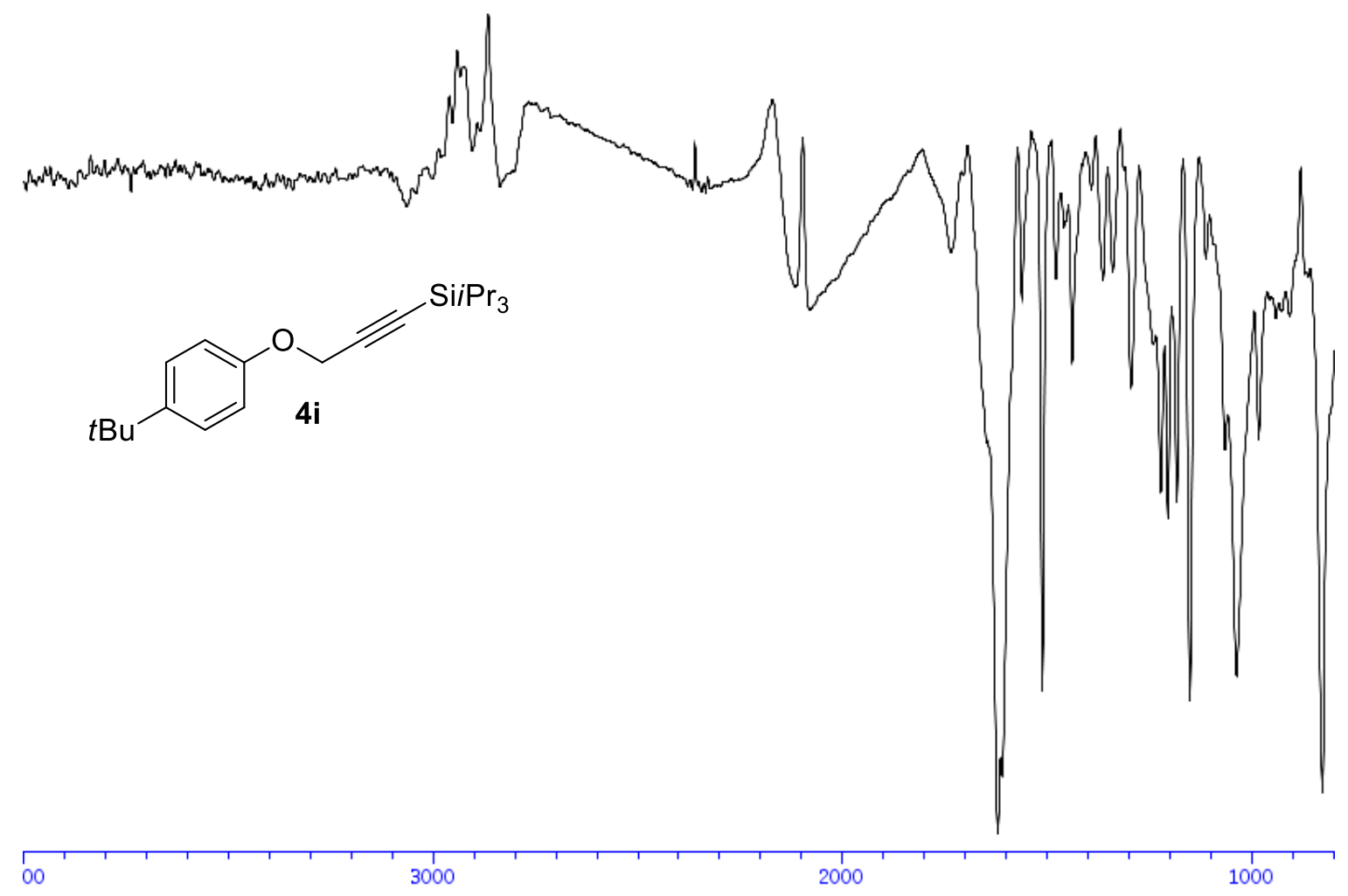


${ }^{1}$ H-NMR (400 MHz, CDCl3)

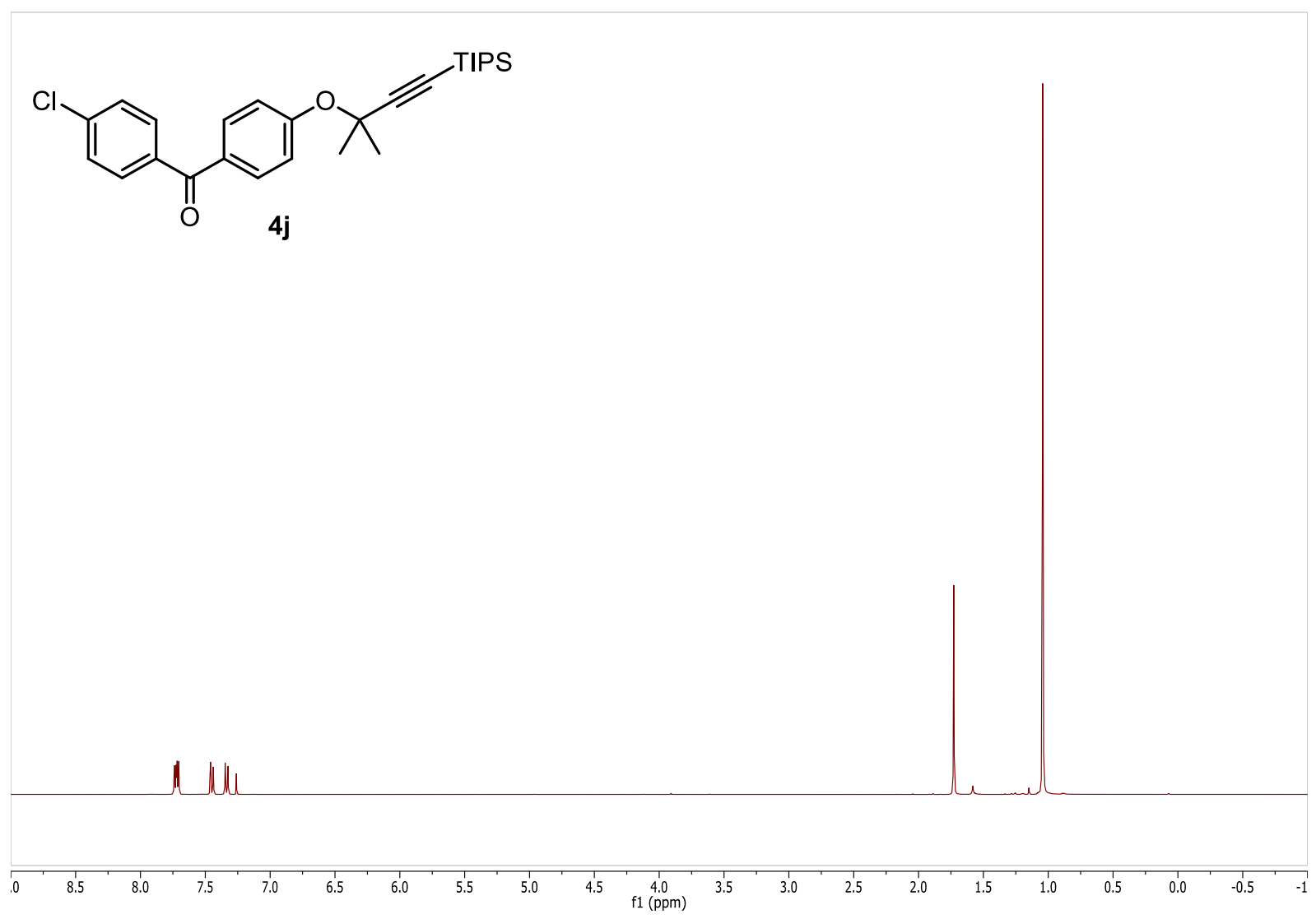

${ }^{13} \mathrm{C}-\mathrm{NMR}$ (101 MHz, $\left.\mathrm{CDCl}_{3}\right)$

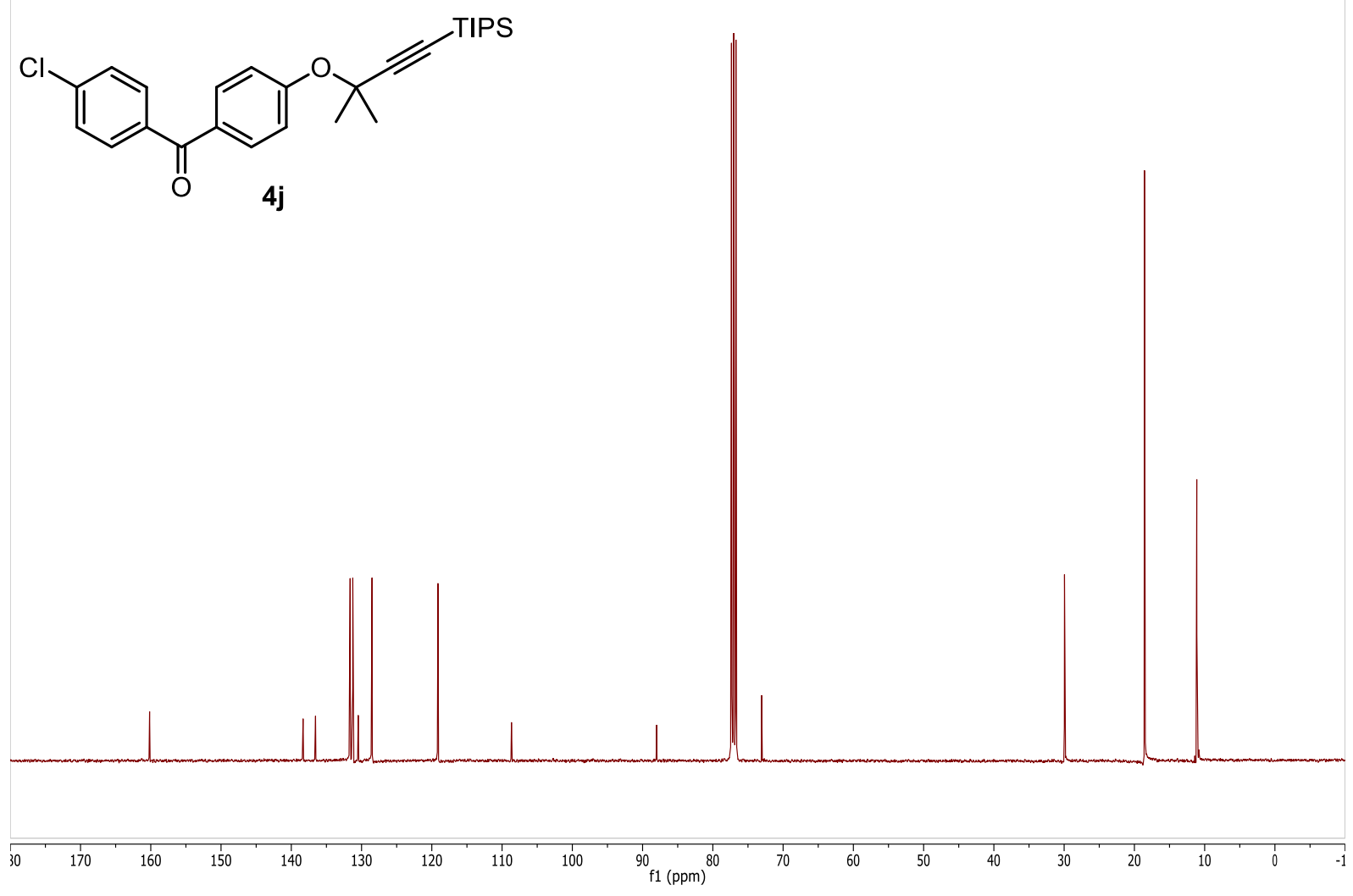

S53 
IR Spectra

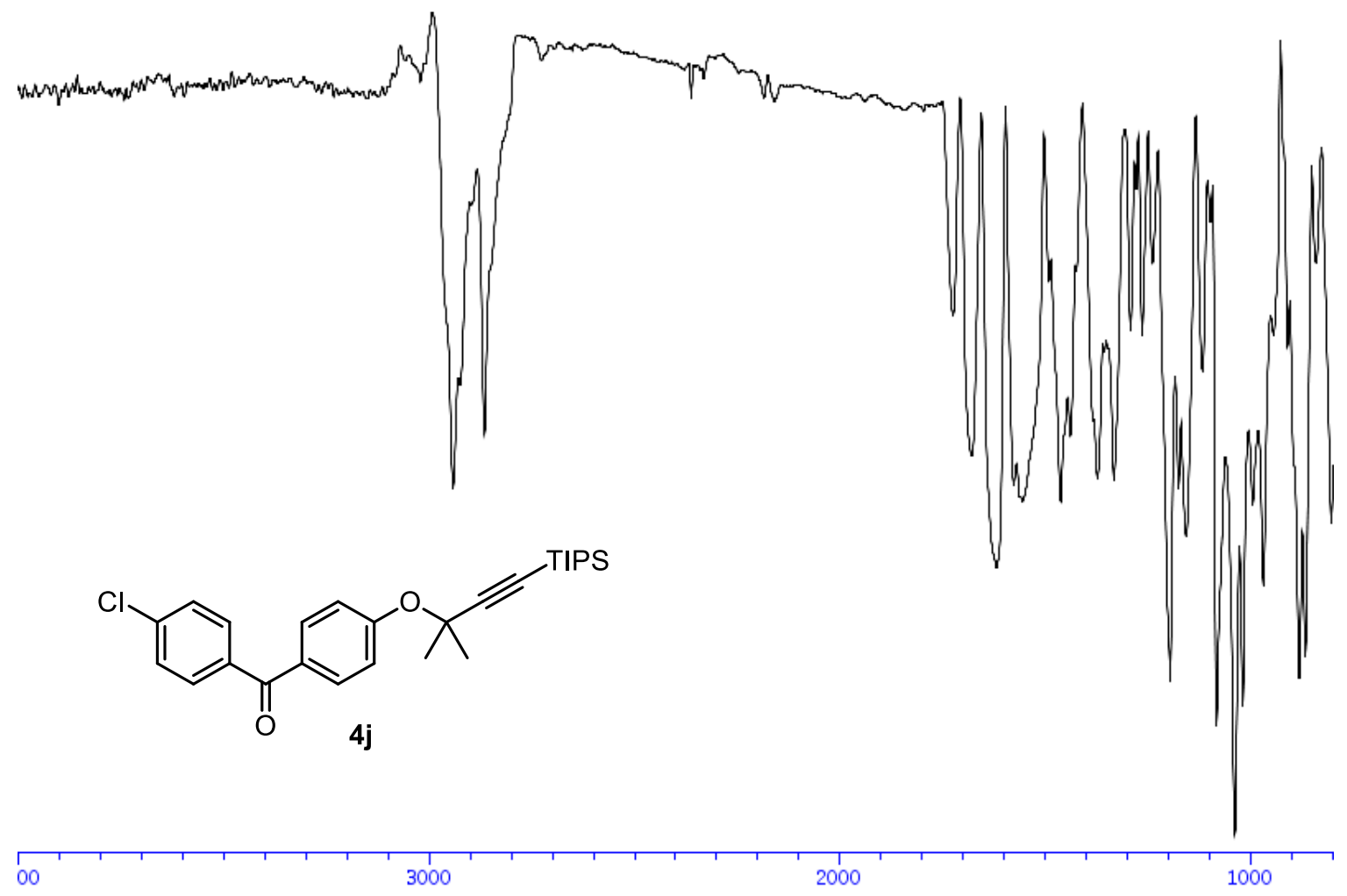


${ }^{1}$ H-NMR (400 MHz, CDCl3)
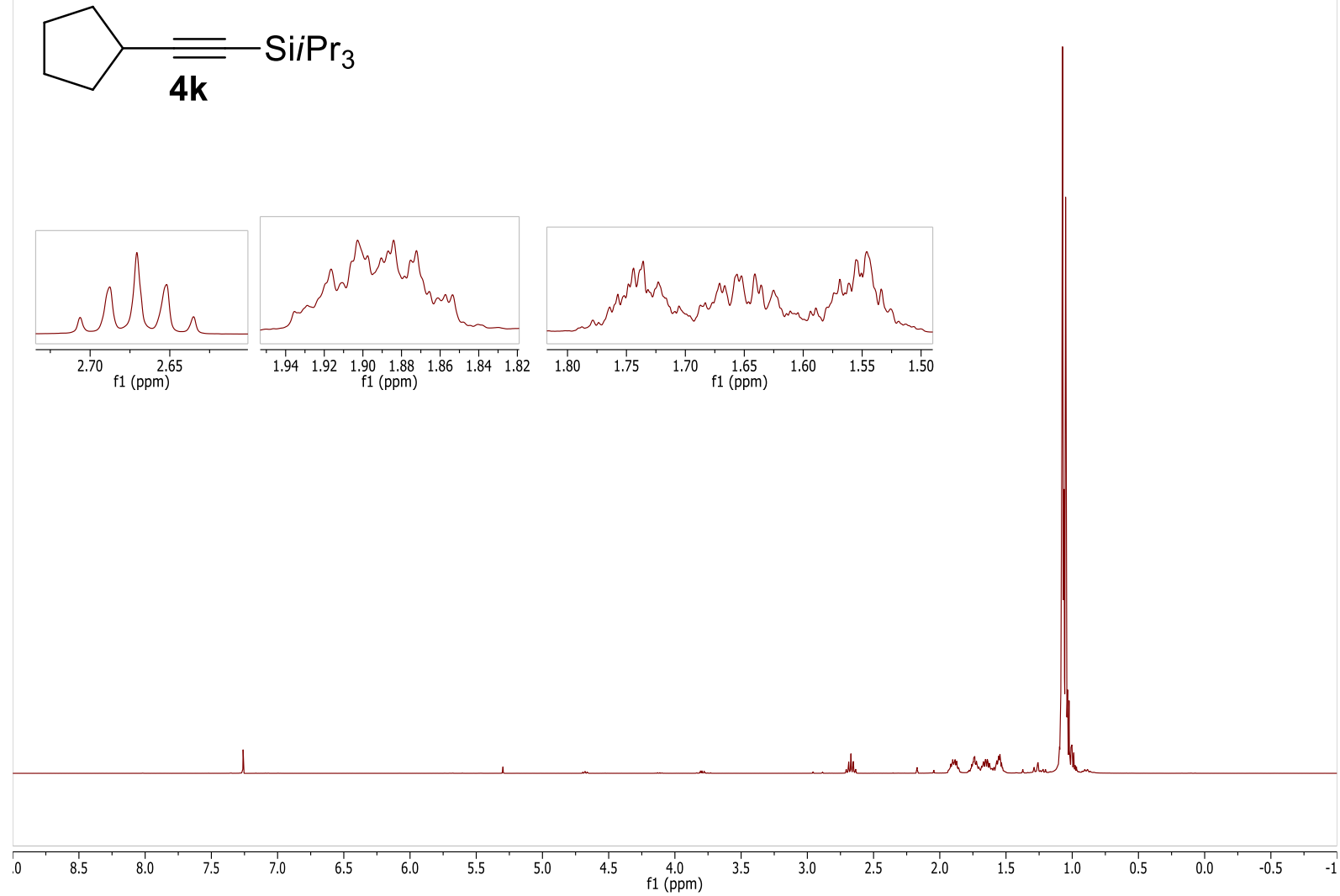

${ }^{13} \mathrm{C}-\mathrm{NMR}$ (101 MHz, CDCl3)
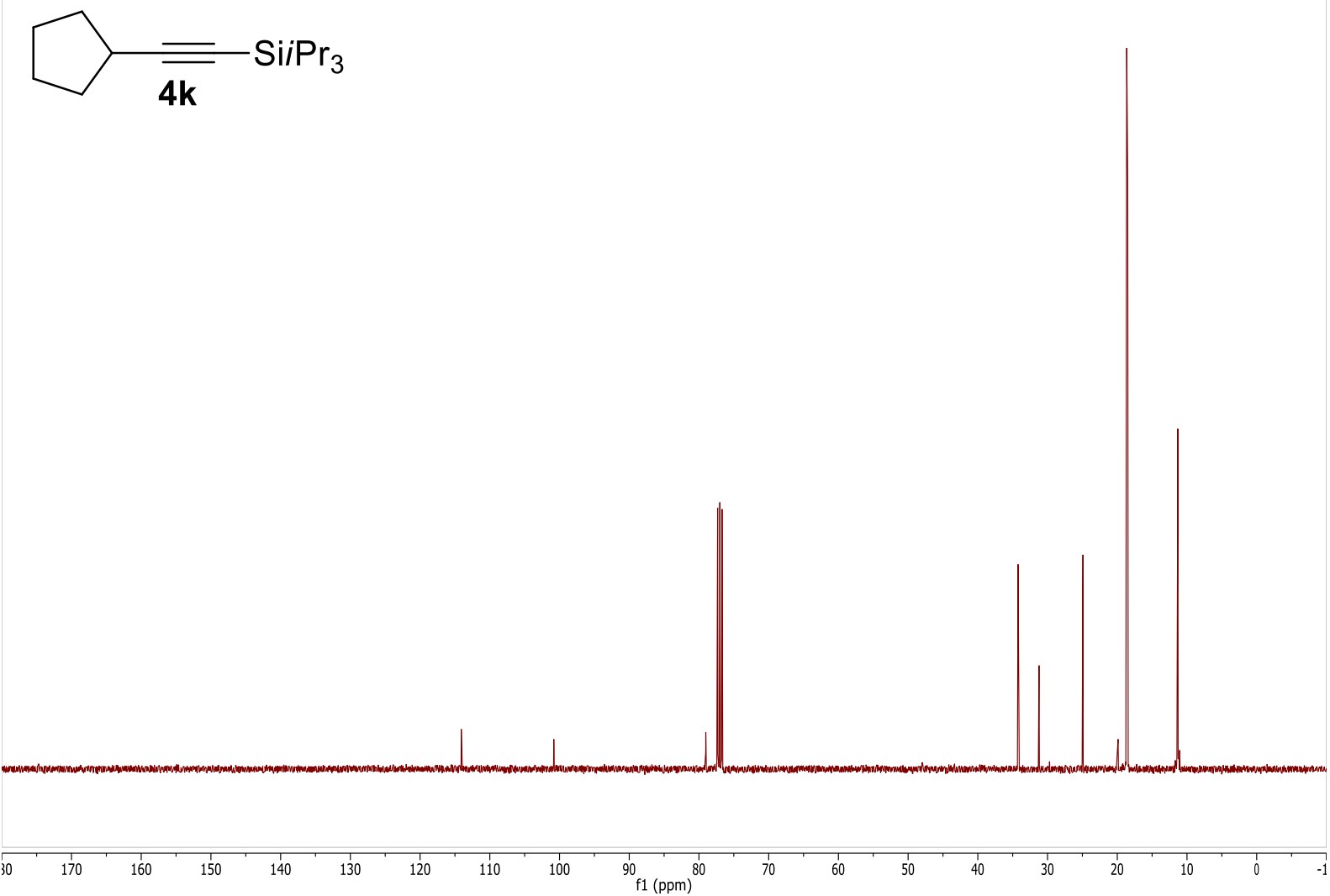
${ }^{1} \mathrm{H}-\mathrm{NMR}\left(400 \mathrm{MHz}, \mathrm{CDCl}_{3}\right)$
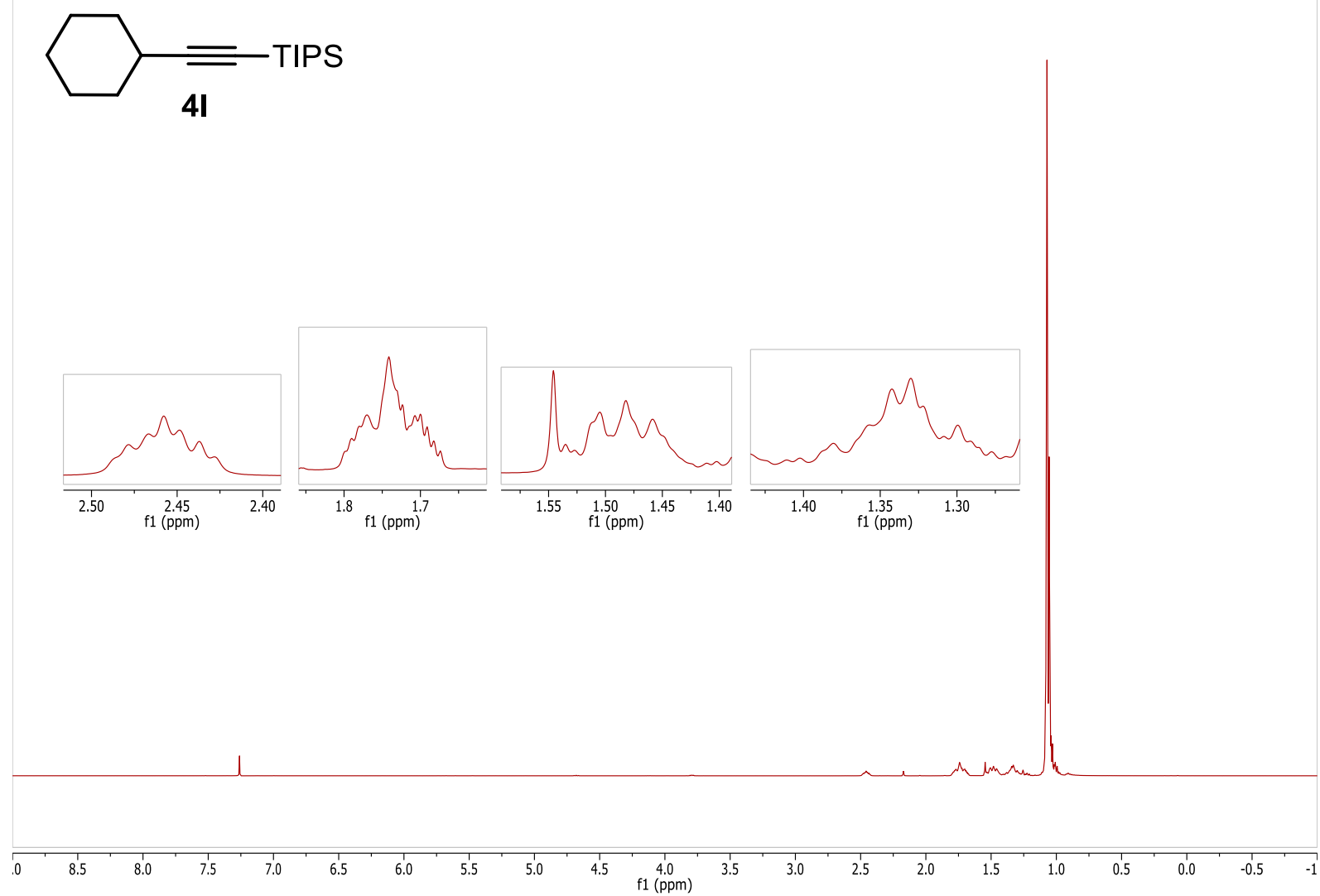

${ }^{13}$ C-NMR (101 MHz, CDCl3)

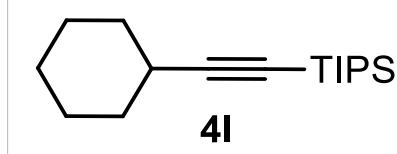

4 I

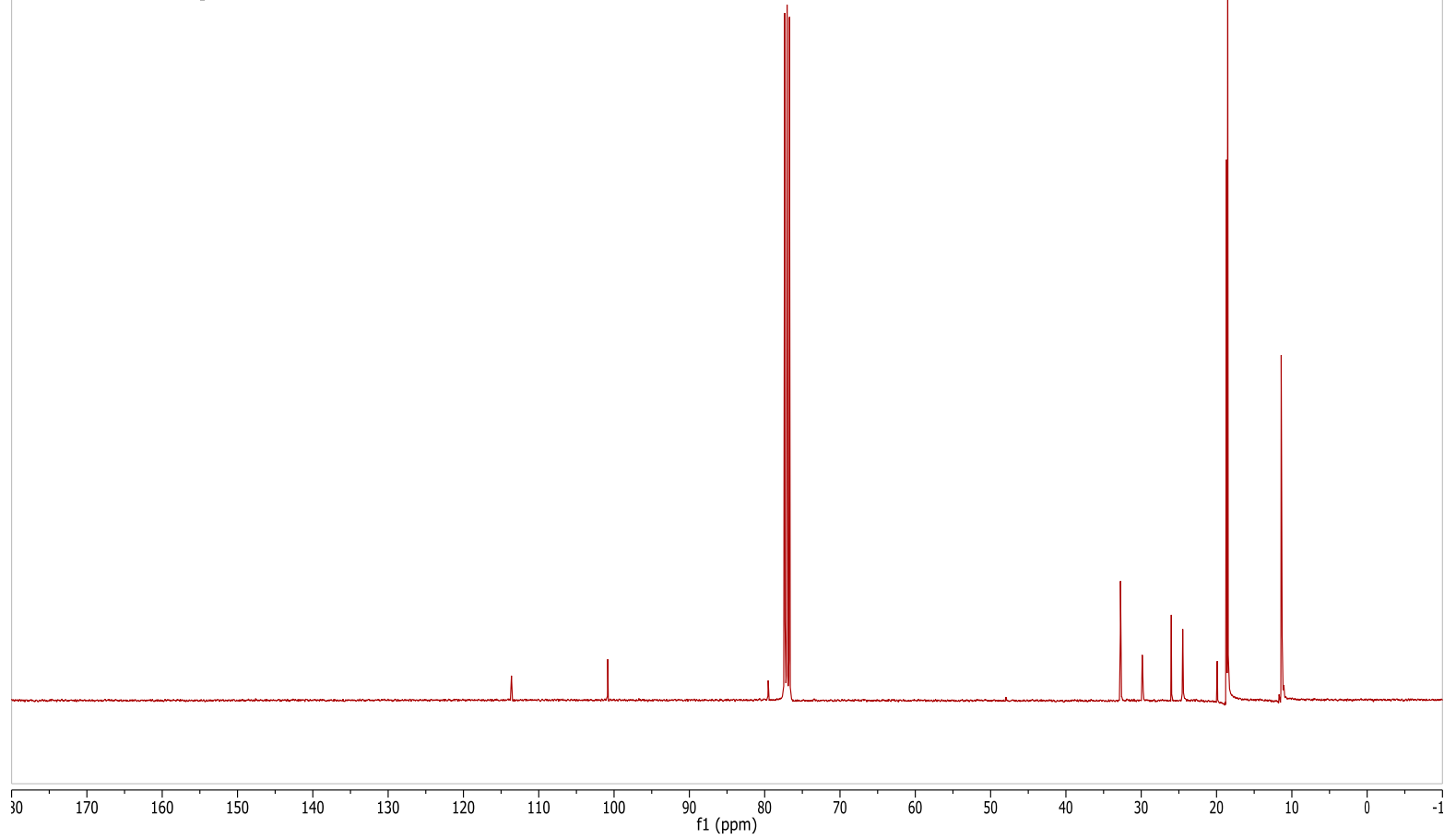




\section{IR Spectra}

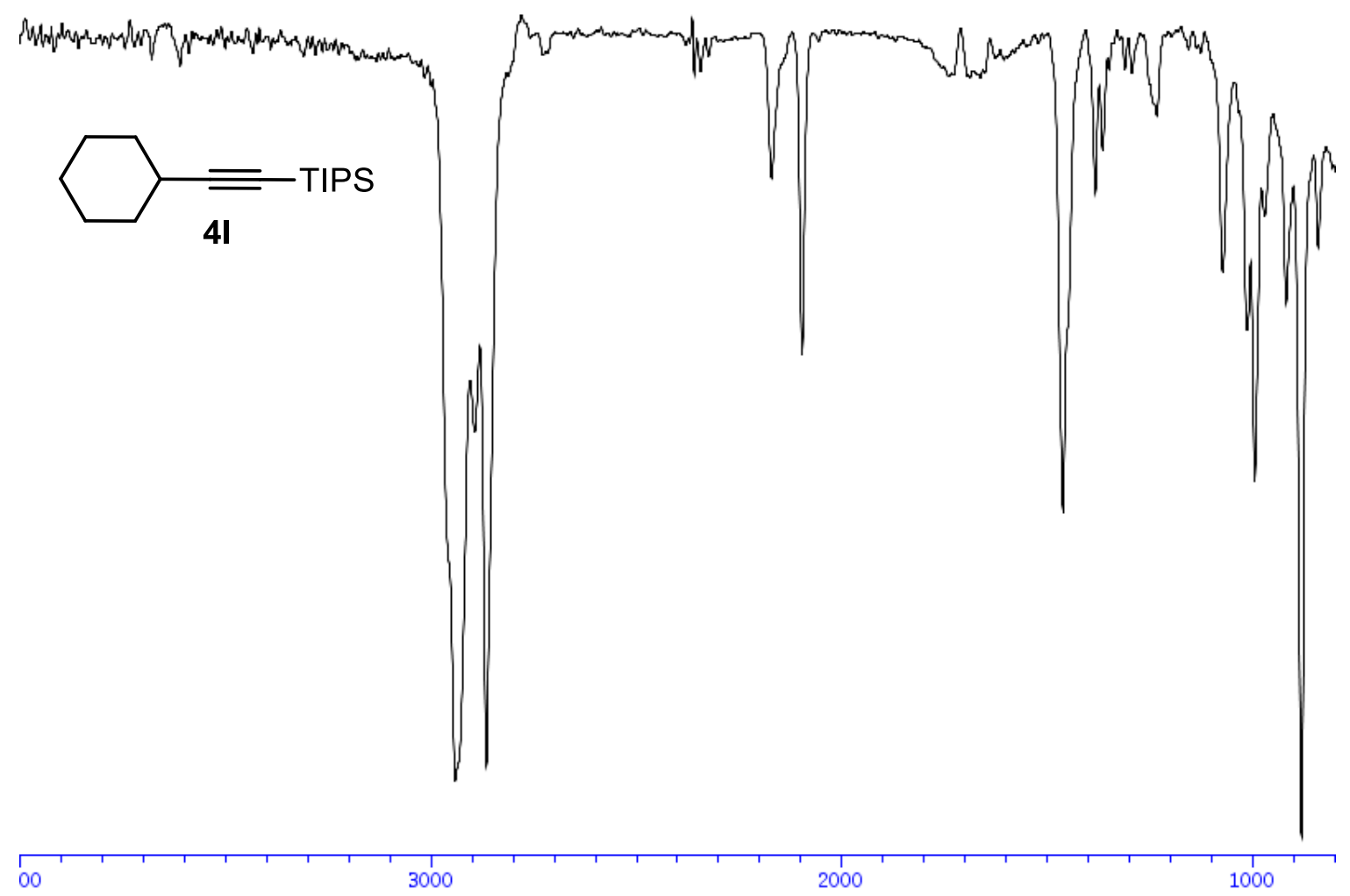


${ }^{1} \mathrm{H}-\mathrm{NMR}\left(400 \mathrm{MHz}, \mathrm{CDCl}_{3}\right)$

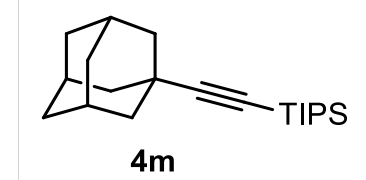

$4 m$

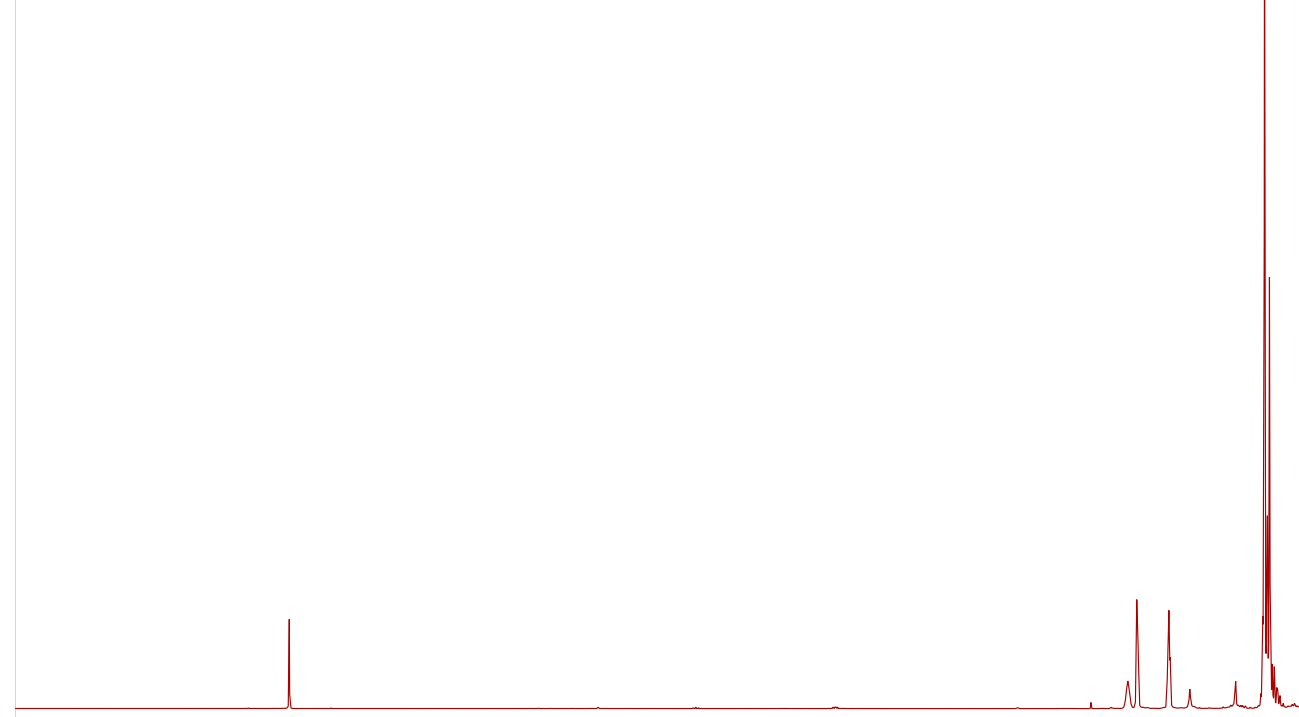

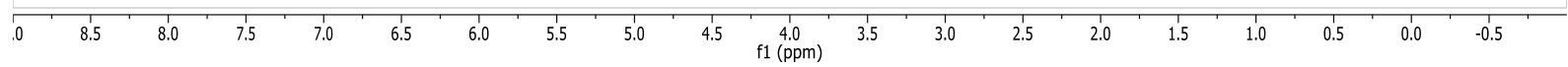

${ }^{13} \mathrm{C}-\mathrm{NMR}(101 \mathrm{MHz}, \mathrm{CDCl} 3)$

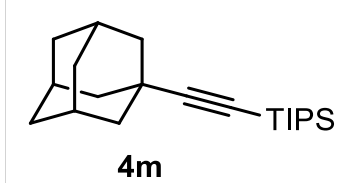

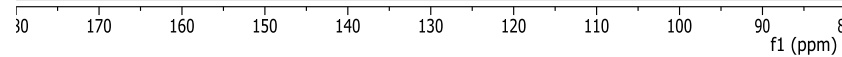




\section{IR Spectra}

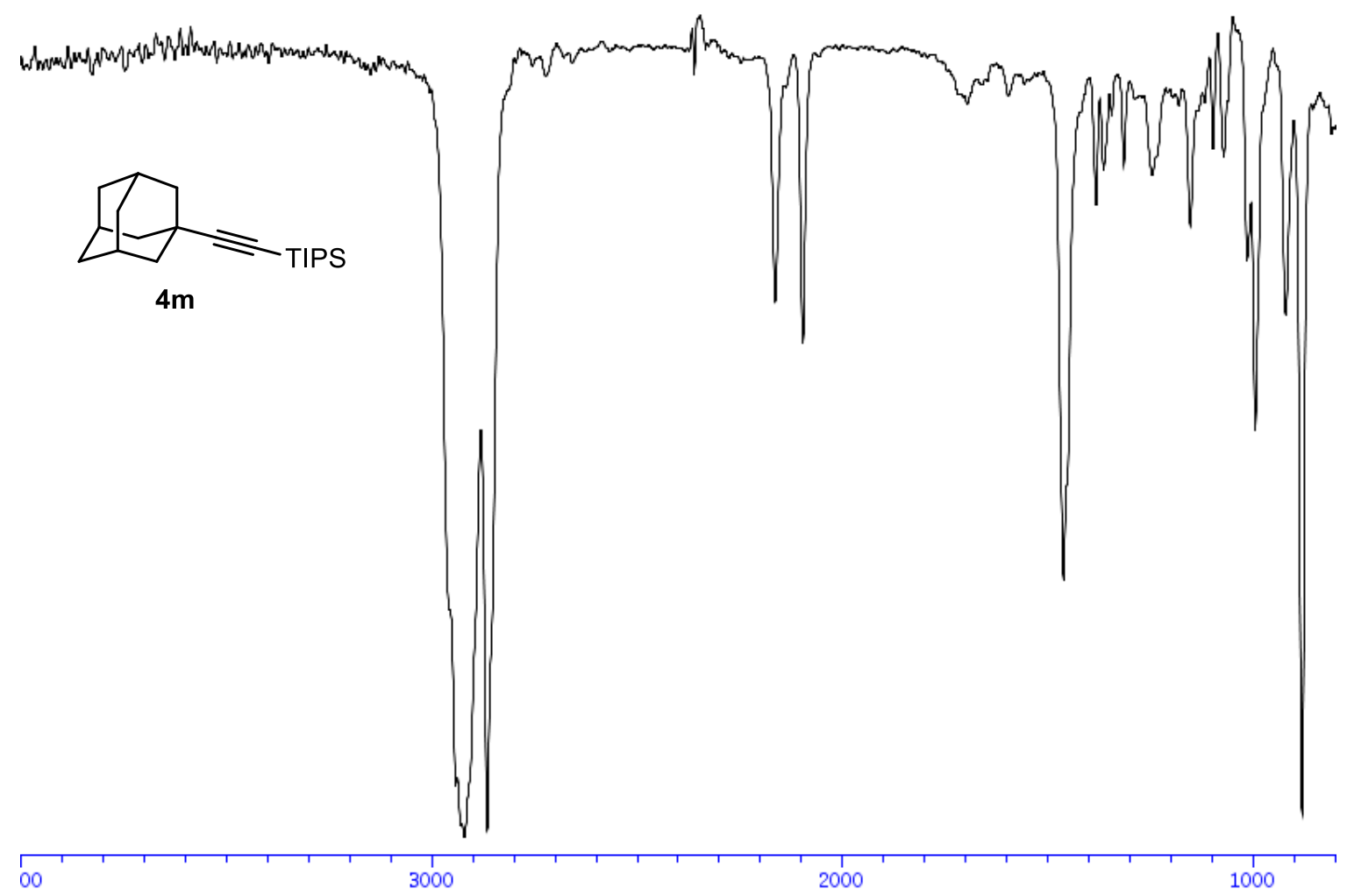


${ }^{1} \mathrm{H}-\mathrm{NMR}\left(400 \mathrm{MHz}, \mathrm{CDCl}_{3}\right)$

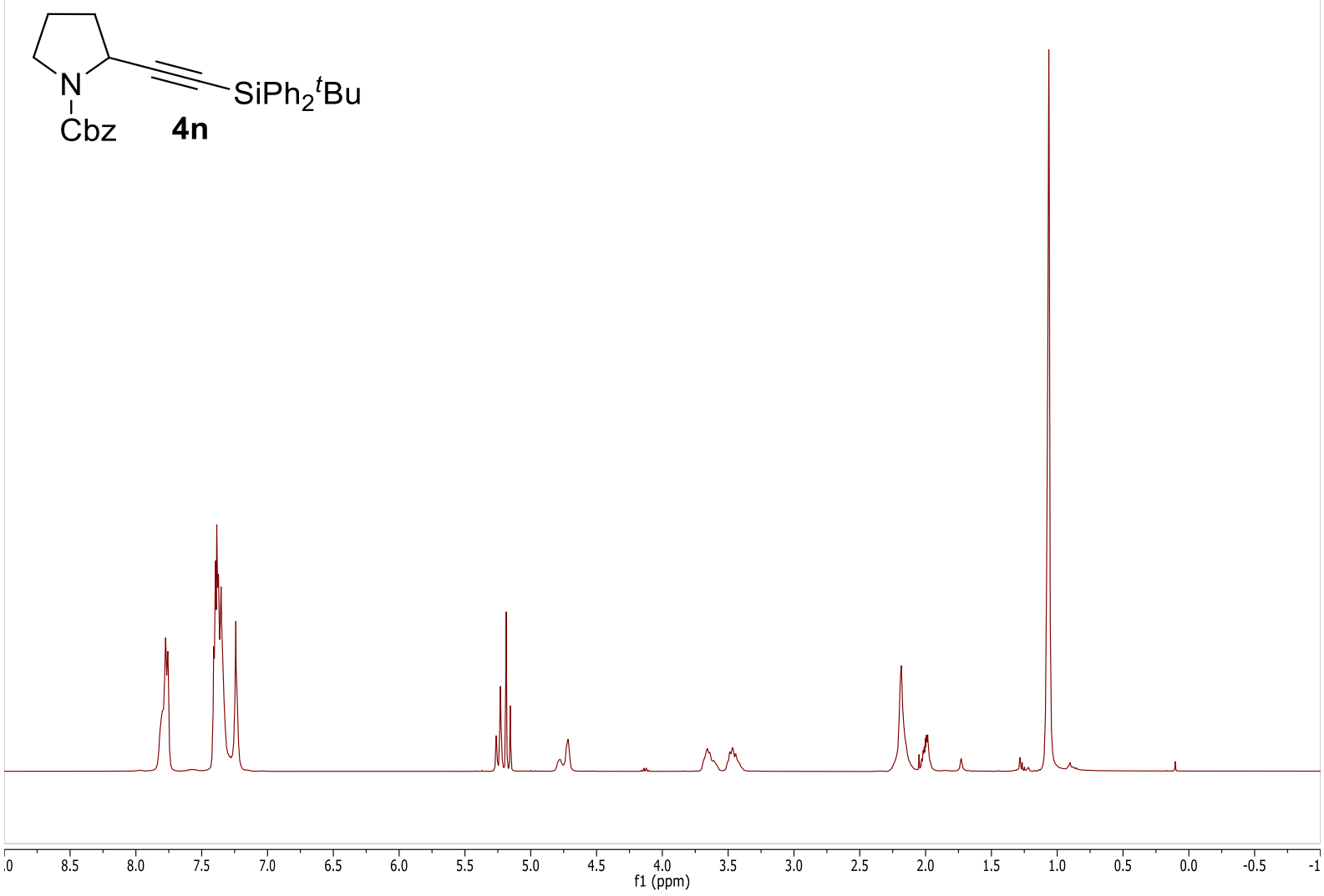

${ }^{13} \mathrm{C}$-NMR (101 MHz, $\mathrm{CDCl}_{3}$ )

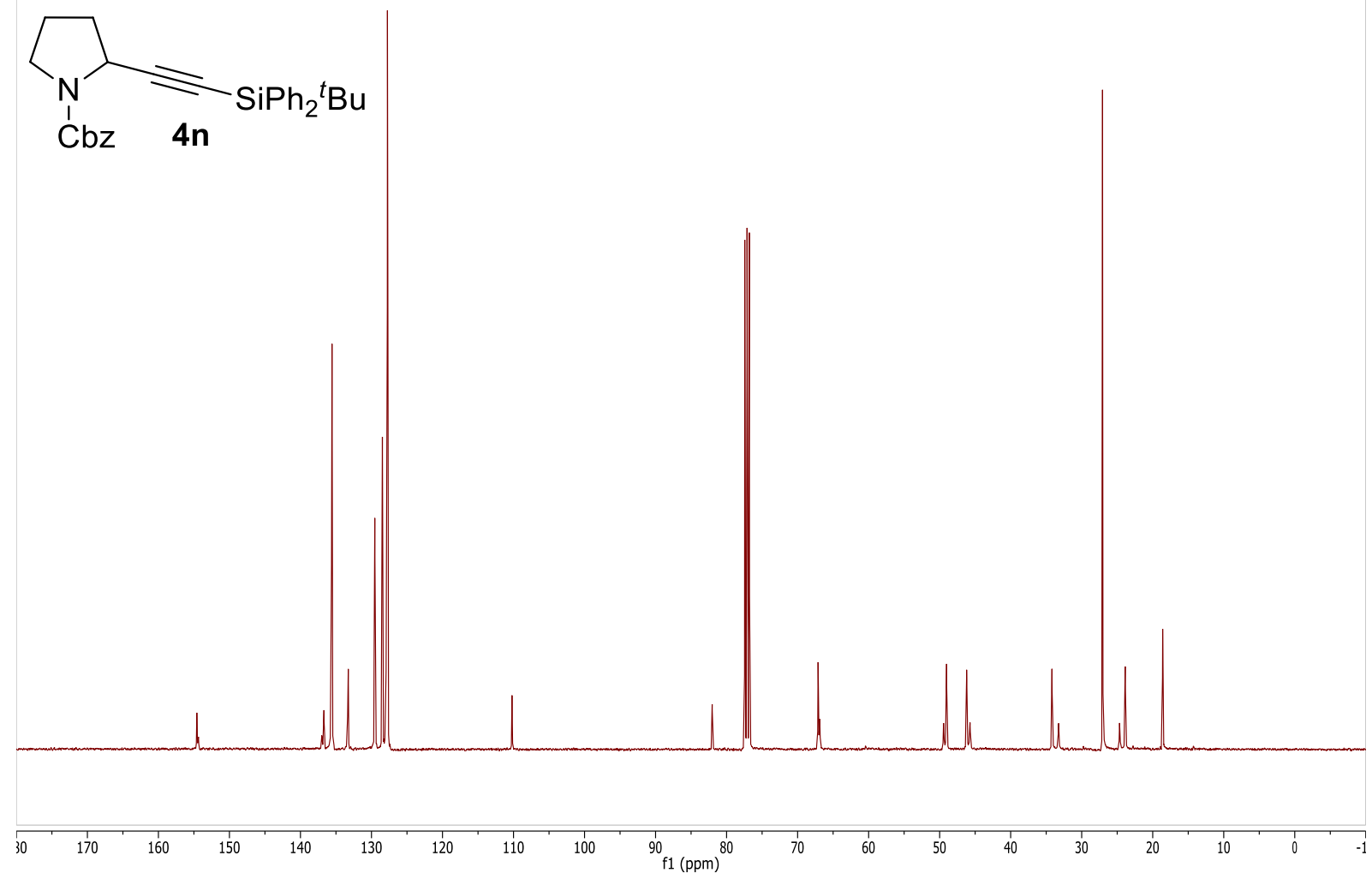




\section{IR Spectra}

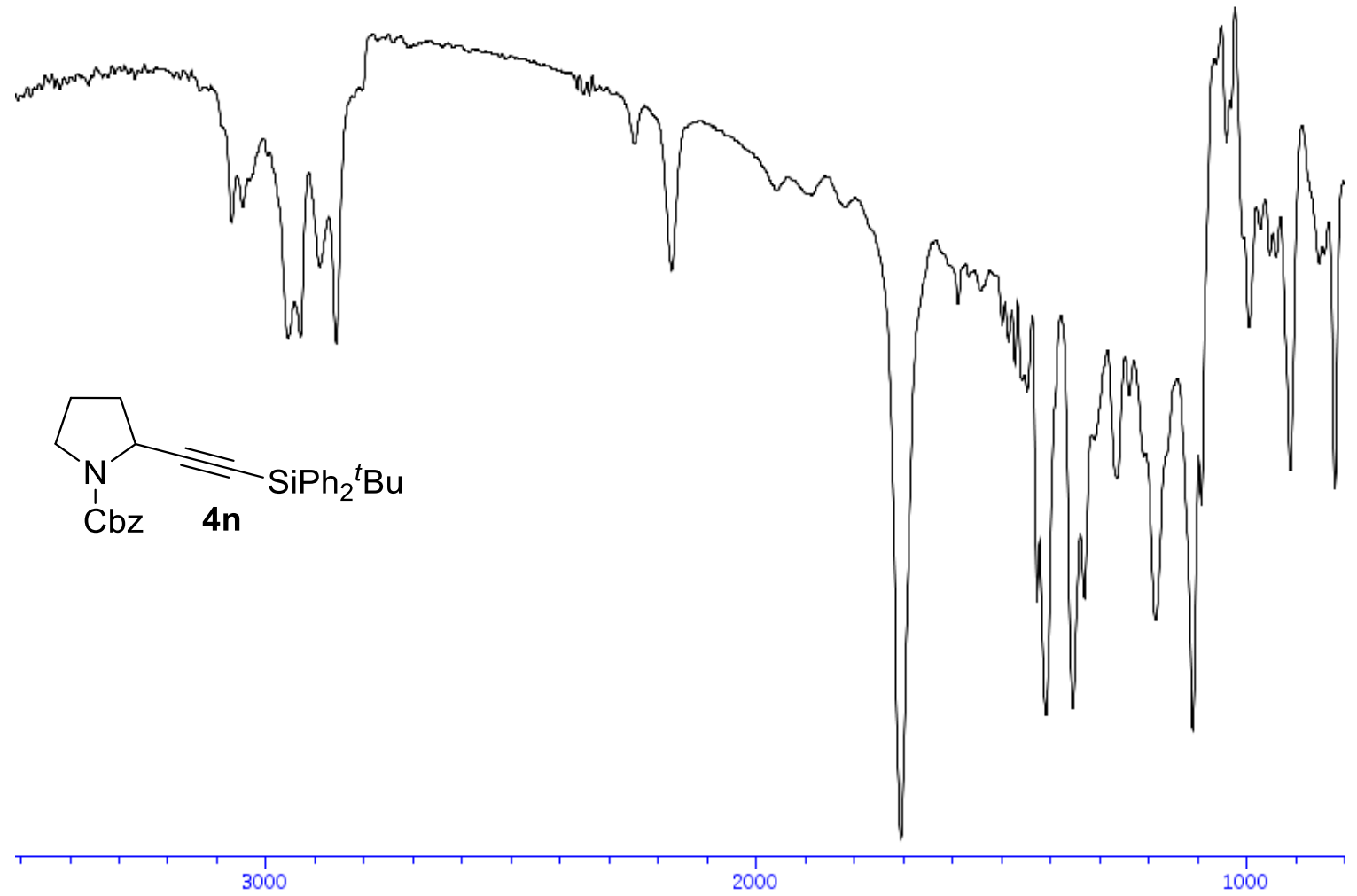


${ }^{1} \mathrm{H}-\mathrm{NMR}\left(400 \mathrm{MHz}, \mathrm{CDCl}_{3}\right)$

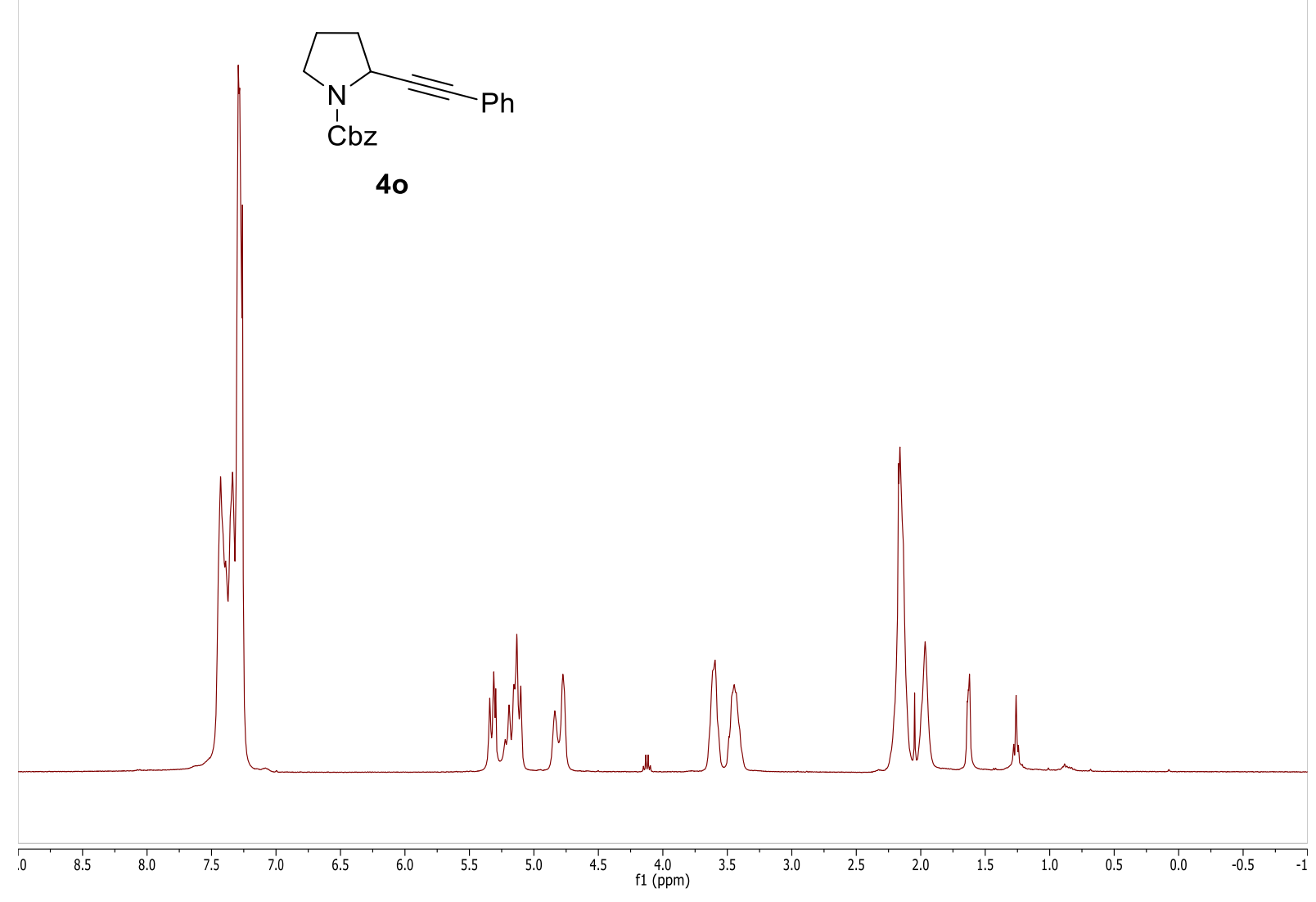

${ }^{13} \mathrm{C}$-NMR (101 MHz, $\mathrm{CDCl}_{3}$ )

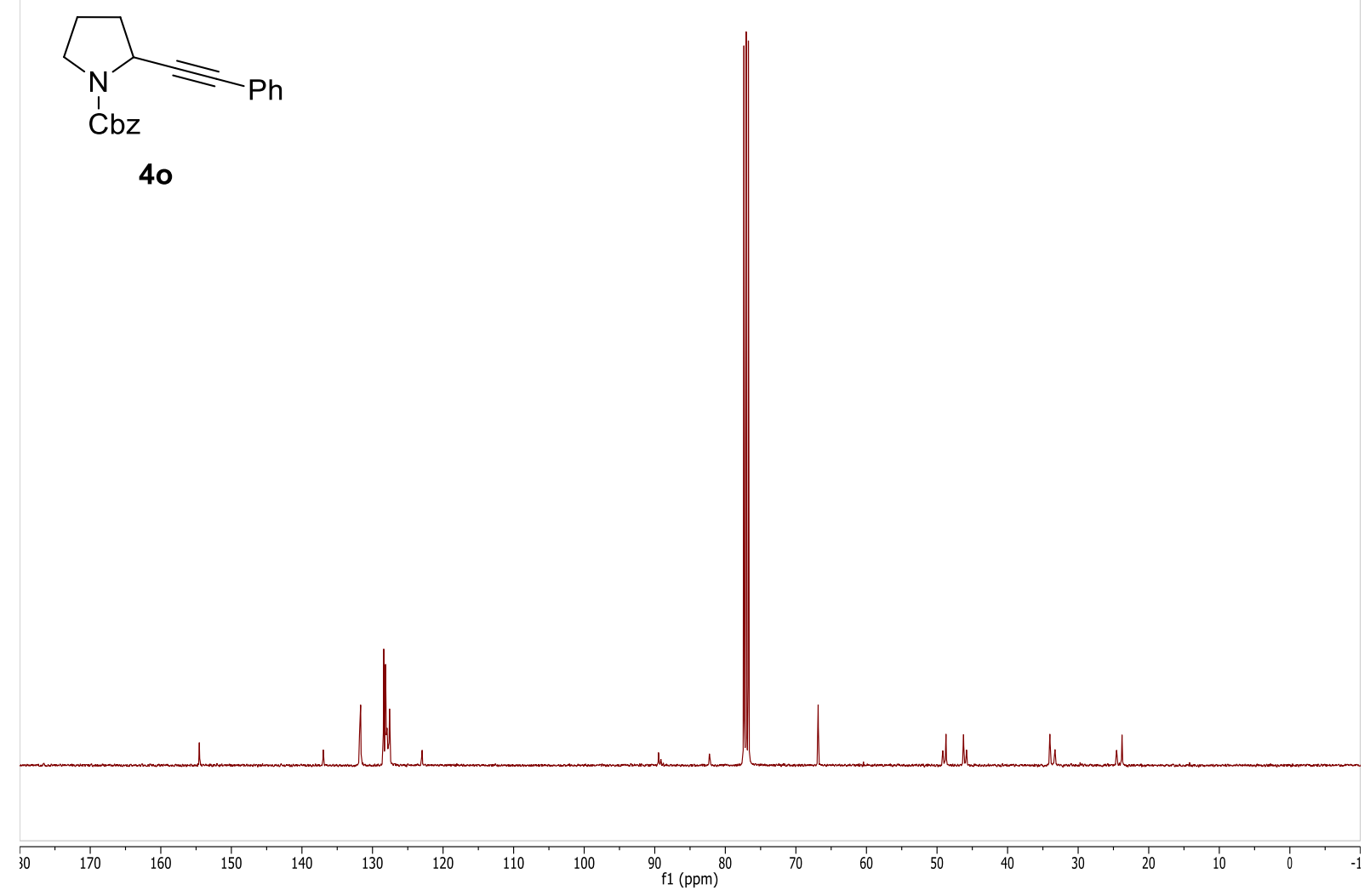




\section{IR Spectra}

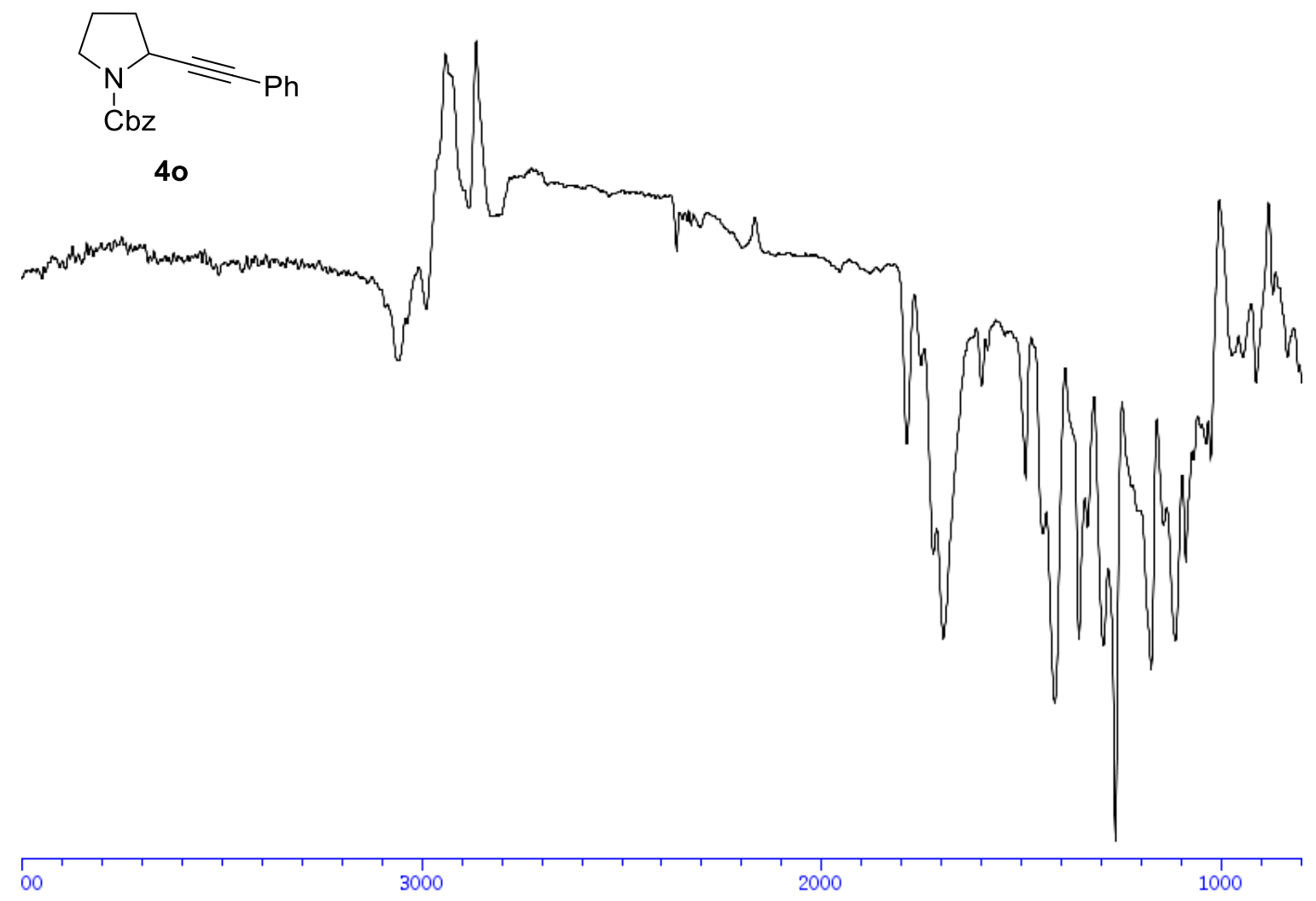


${ }^{1} \mathrm{H}-\mathrm{NMR}\left(400 \mathrm{MHz}, \mathrm{CDCl}_{3}\right)$
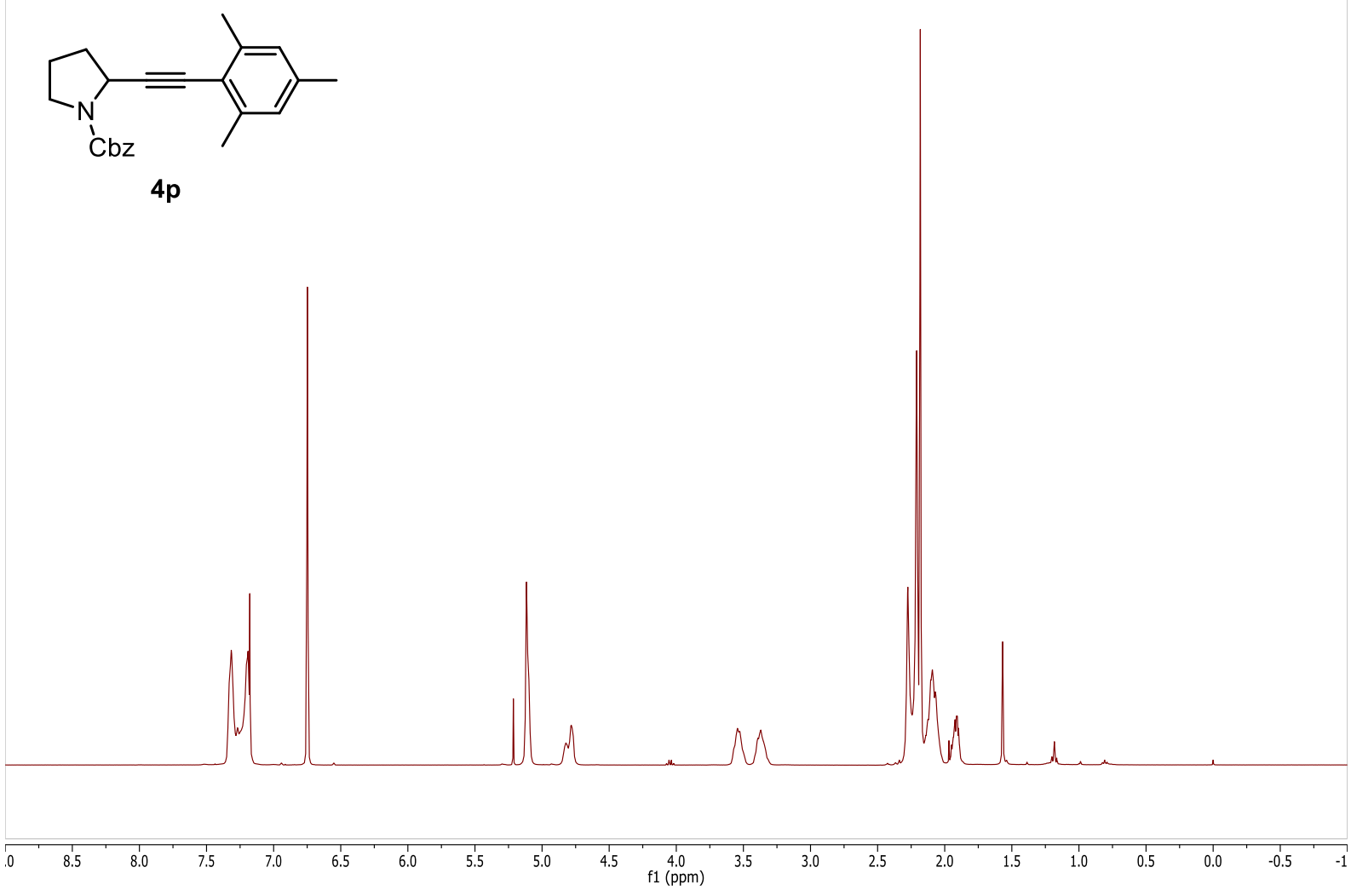

${ }^{13} \mathrm{C}-\mathrm{NMR}$ (101 MHz, $\left.\mathrm{CDCl}_{3}\right)$
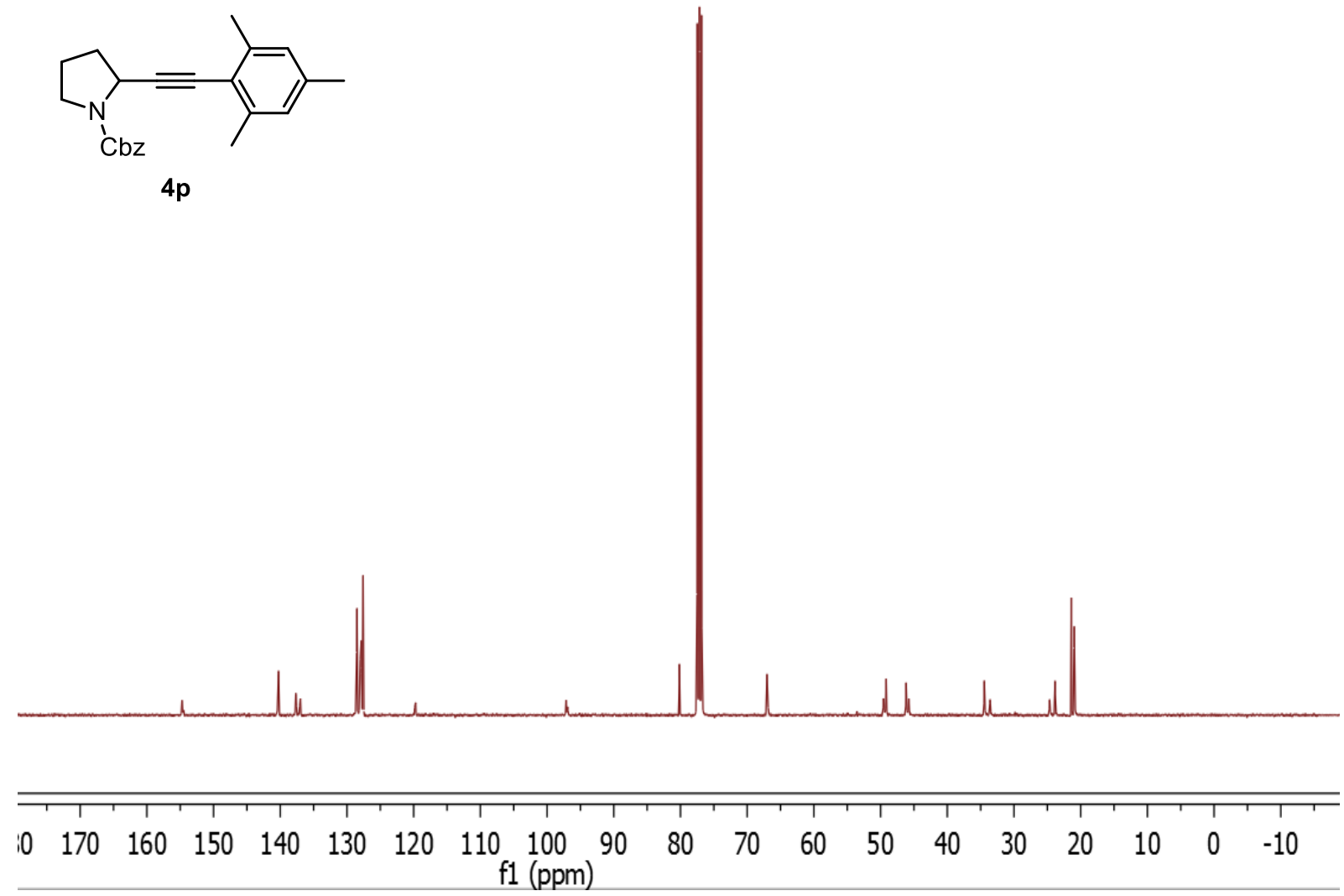


\section{IR Spectra}

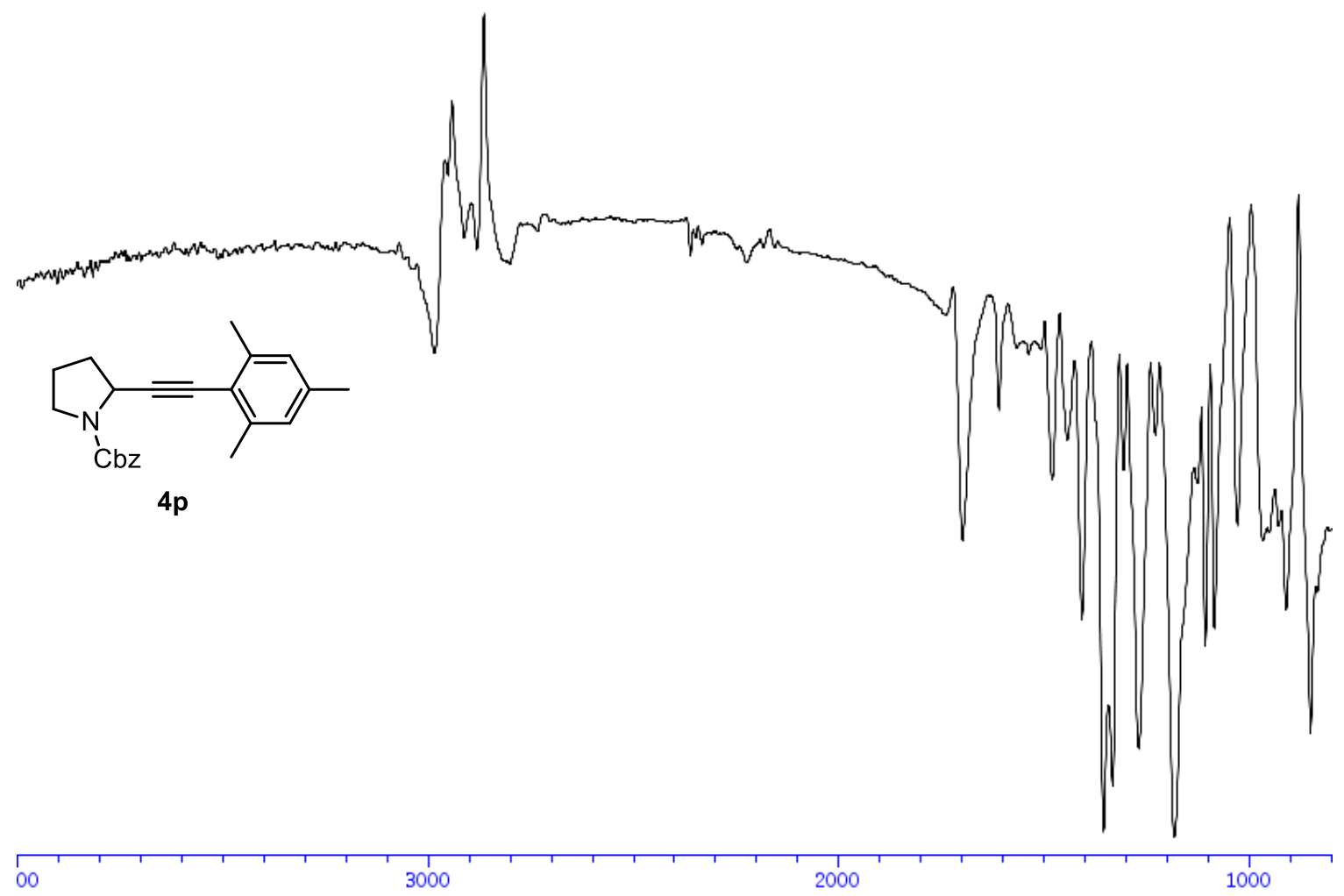


${ }^{1}$ H-NMR (400 MHz, CDCl3)

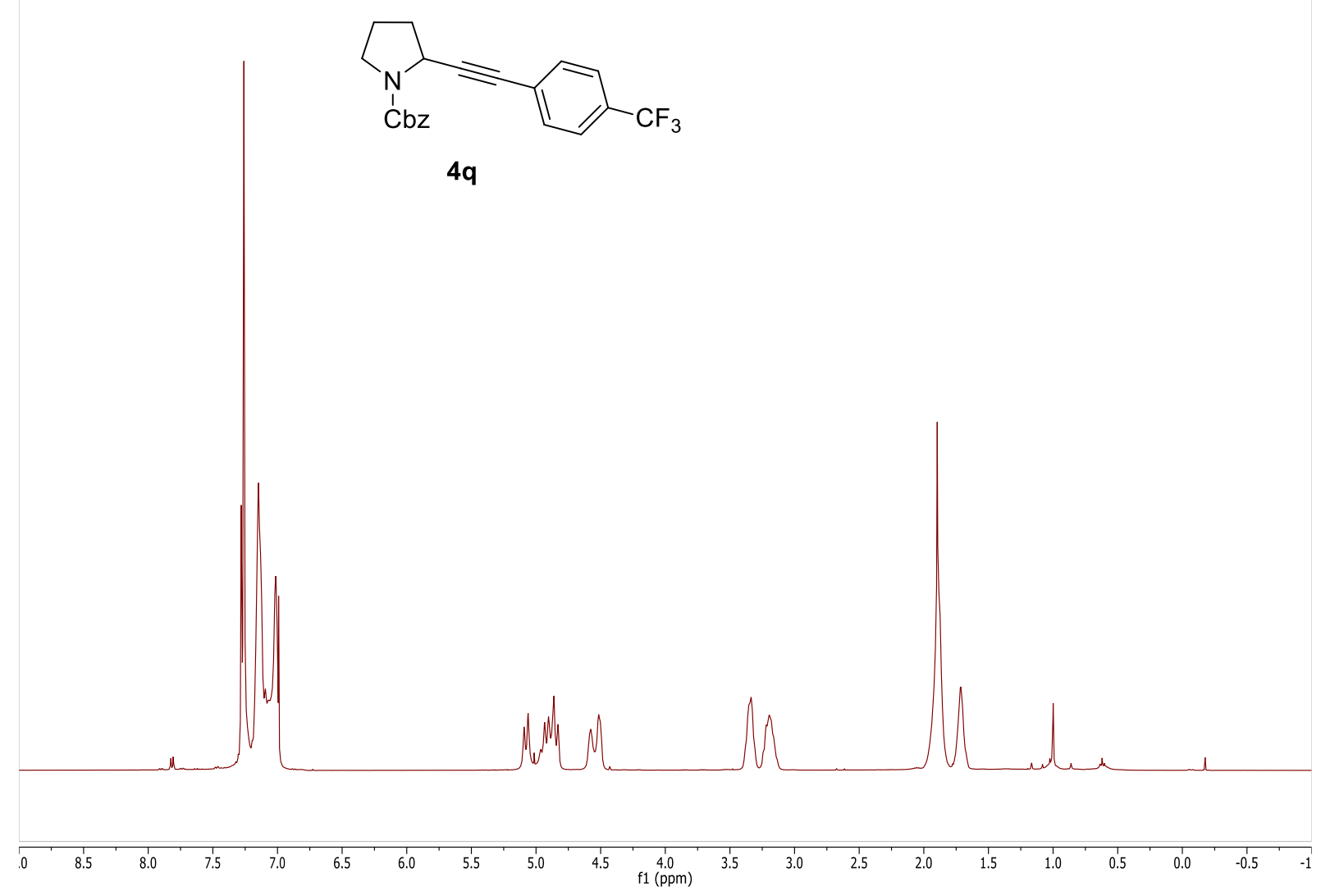

${ }^{13} \mathrm{C}-\mathrm{NMR}$ (101 MHz, CDCl3)

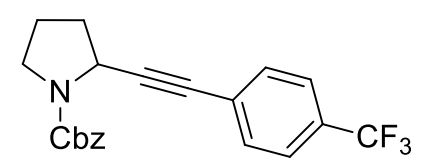

$4 q$
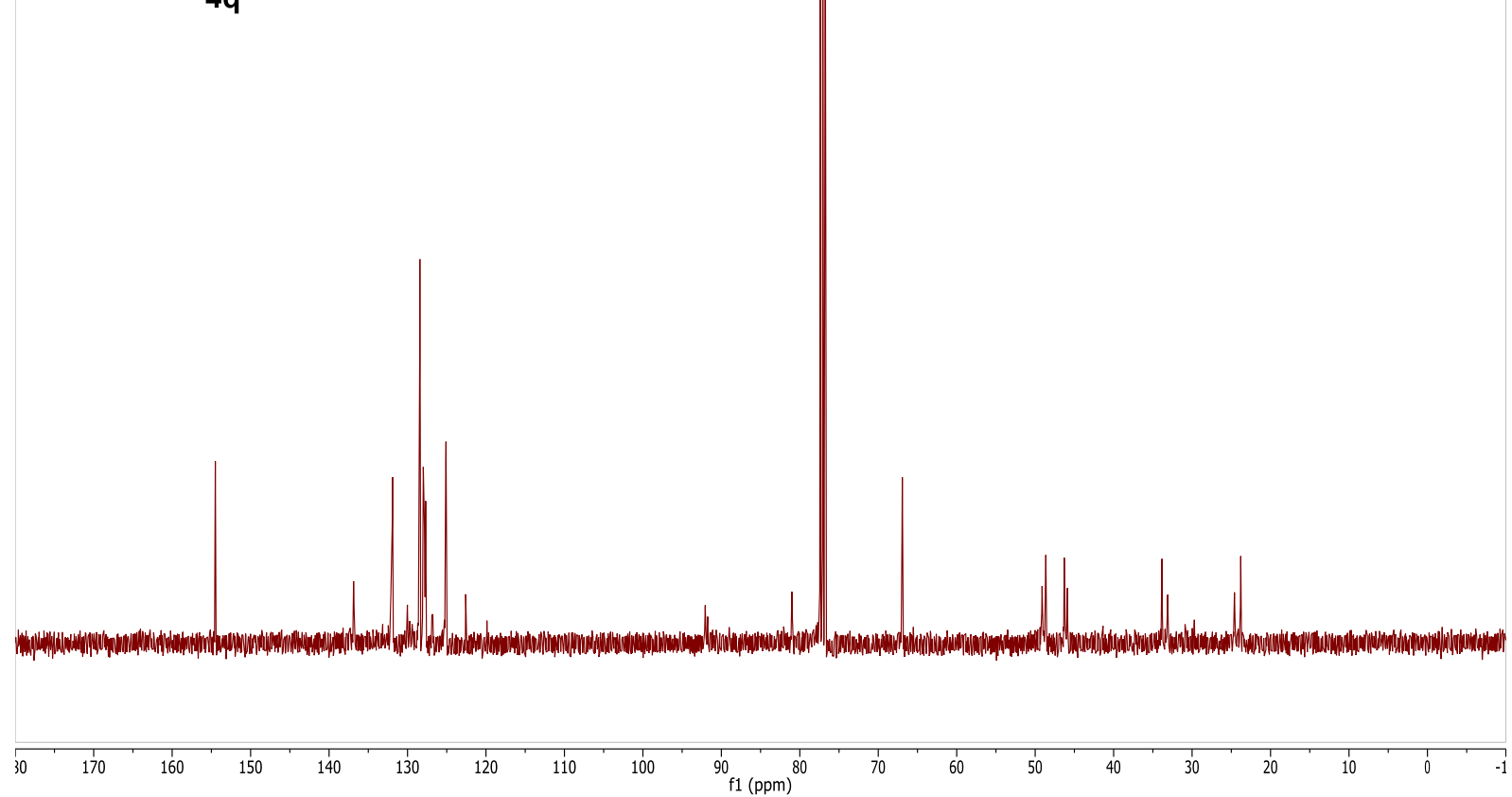
${ }^{1}$ H-NMR (400 MHz, CDCl3)

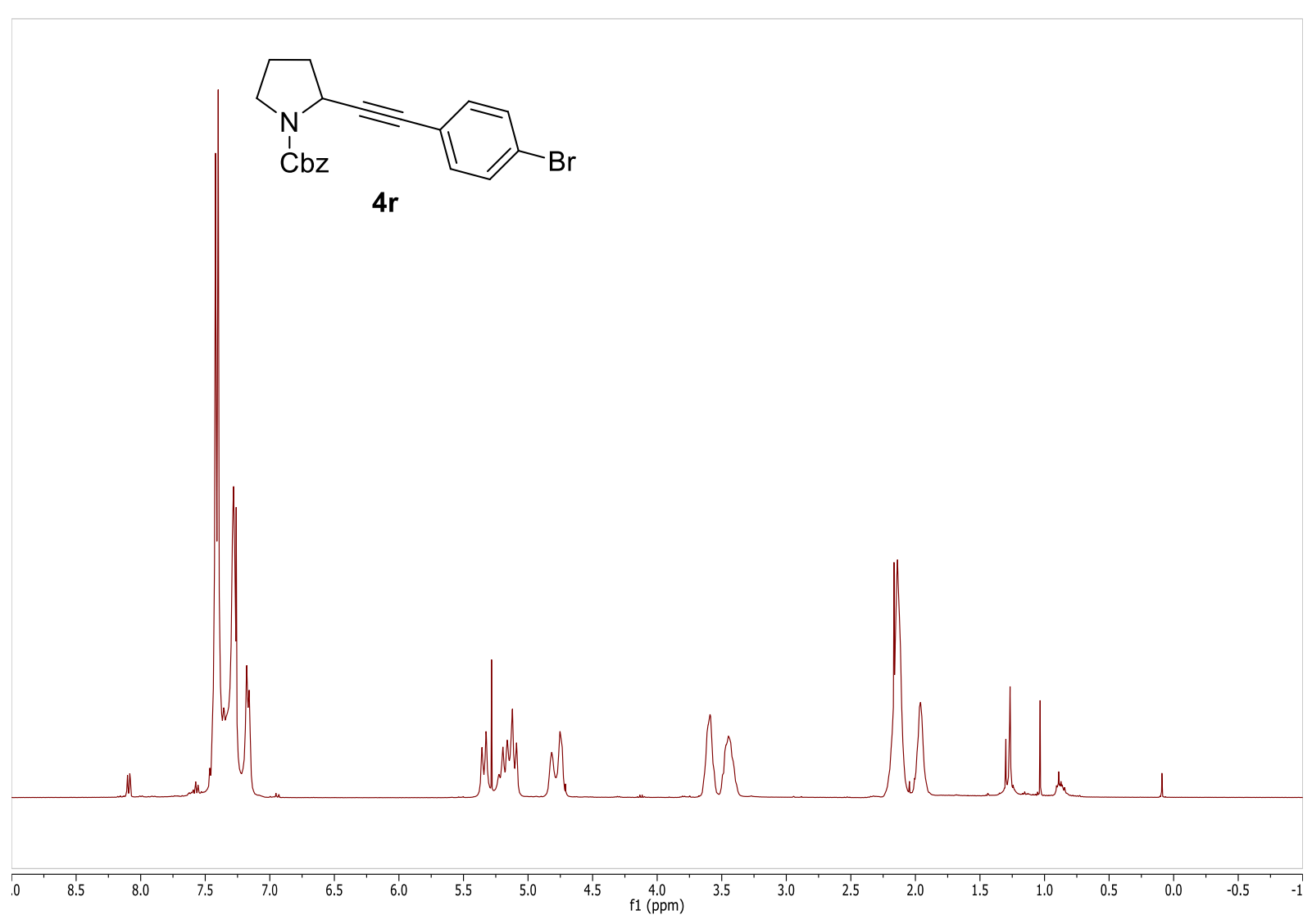

${ }^{13} \mathrm{C}-\mathrm{NMR}$ (101 MHz, CDCl3)

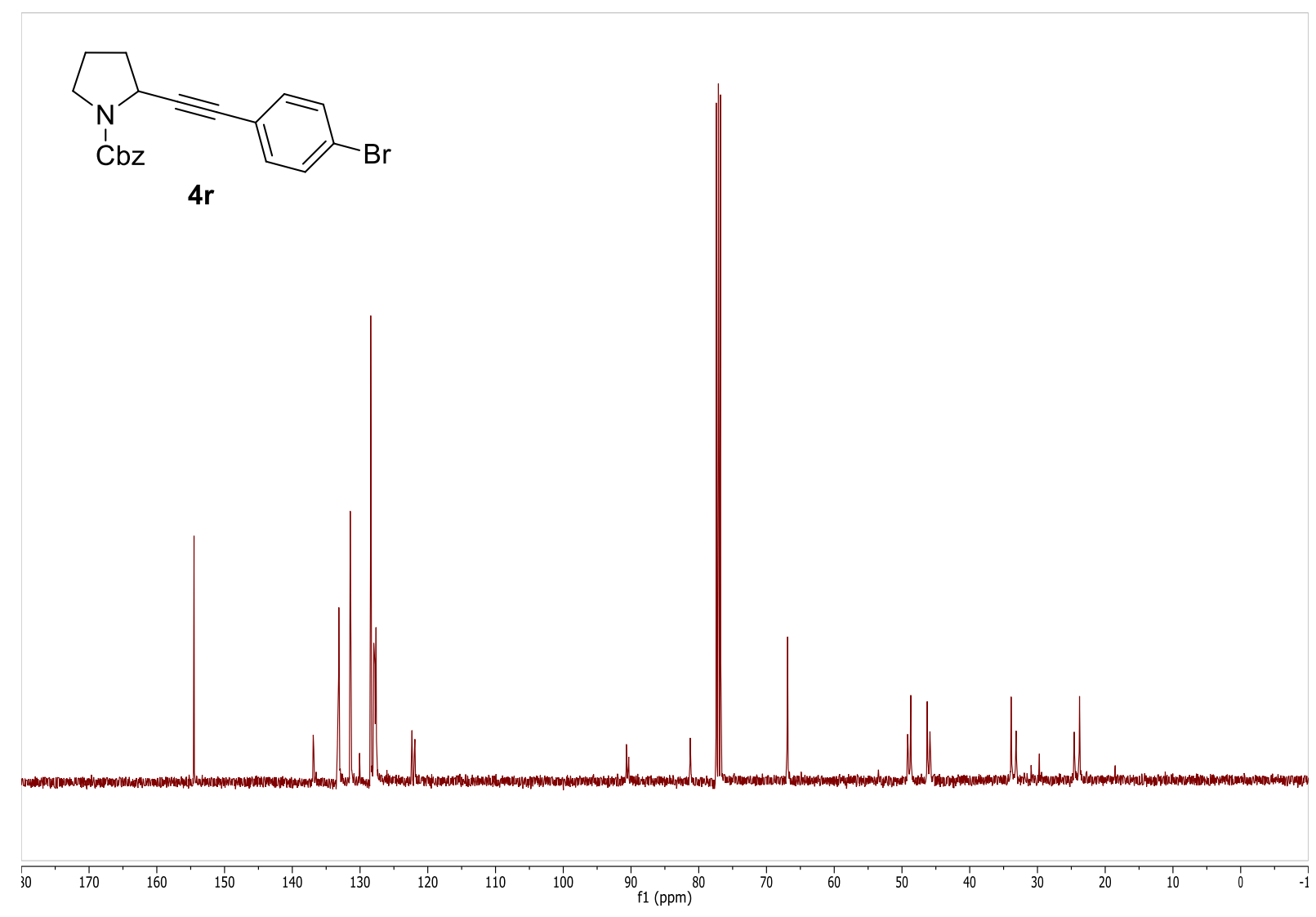

S67 


\section{IR Spectra}

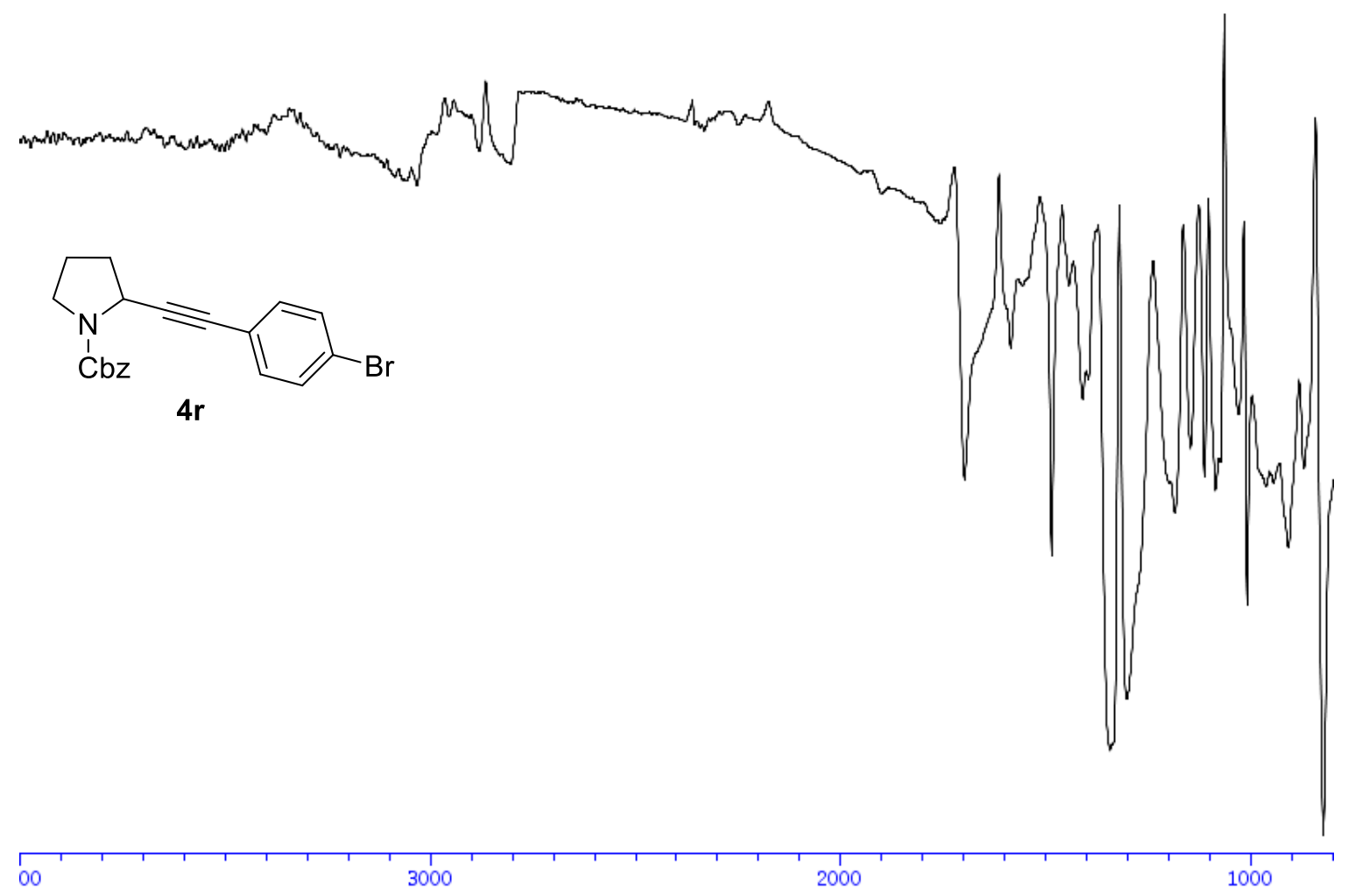


${ }^{1} \mathrm{H}-\mathrm{NMR}\left(400 \mathrm{MHz}, \mathrm{CDCl}_{3}\right)$

$\underset{\mathrm{C} \text { Cbz }}{\longrightarrow}=$
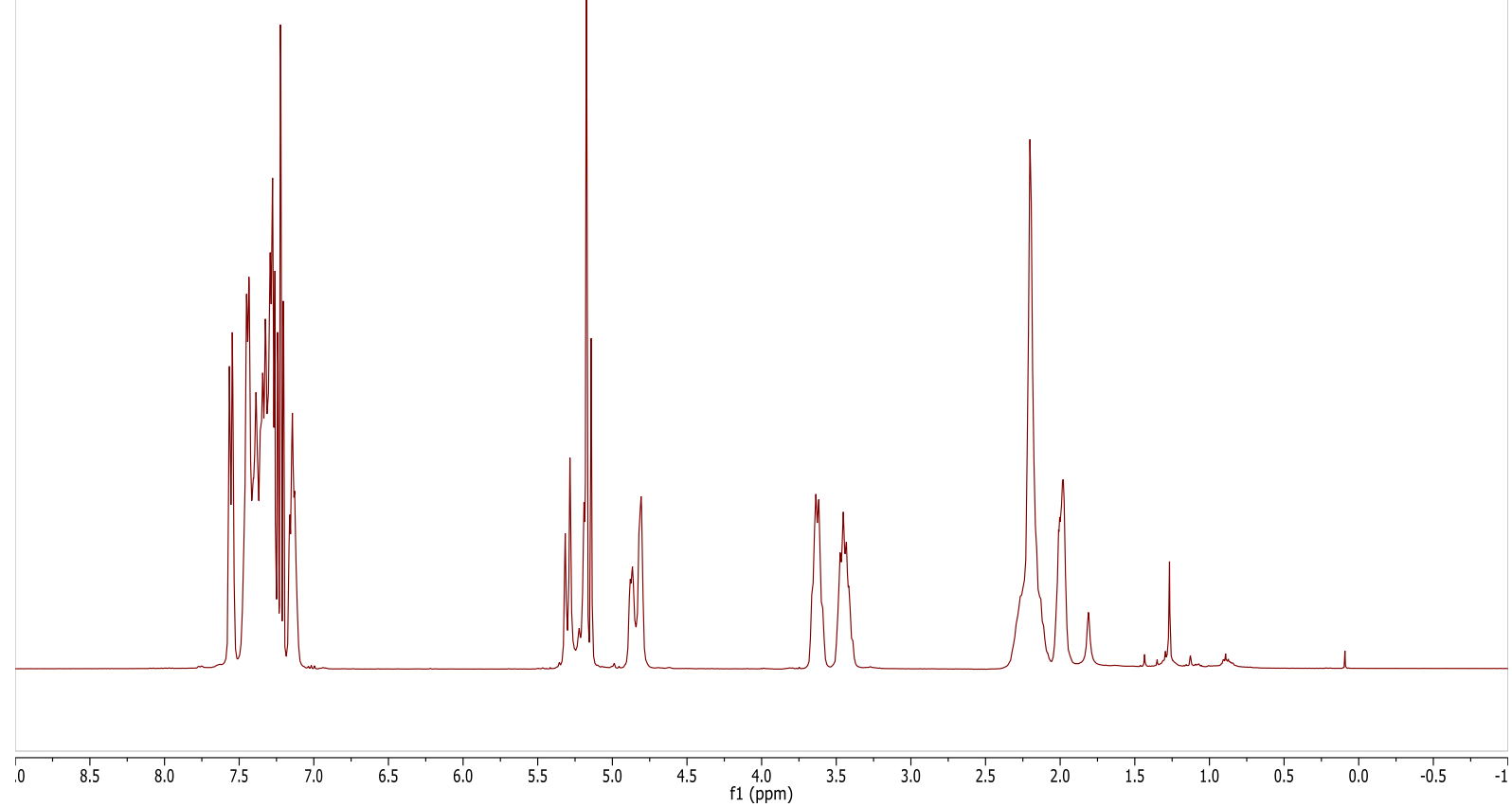

${ }^{13} \mathrm{C}-\mathrm{NMR}\left(101 \mathrm{MHz}, \mathrm{CDCl}_{3}\right)$
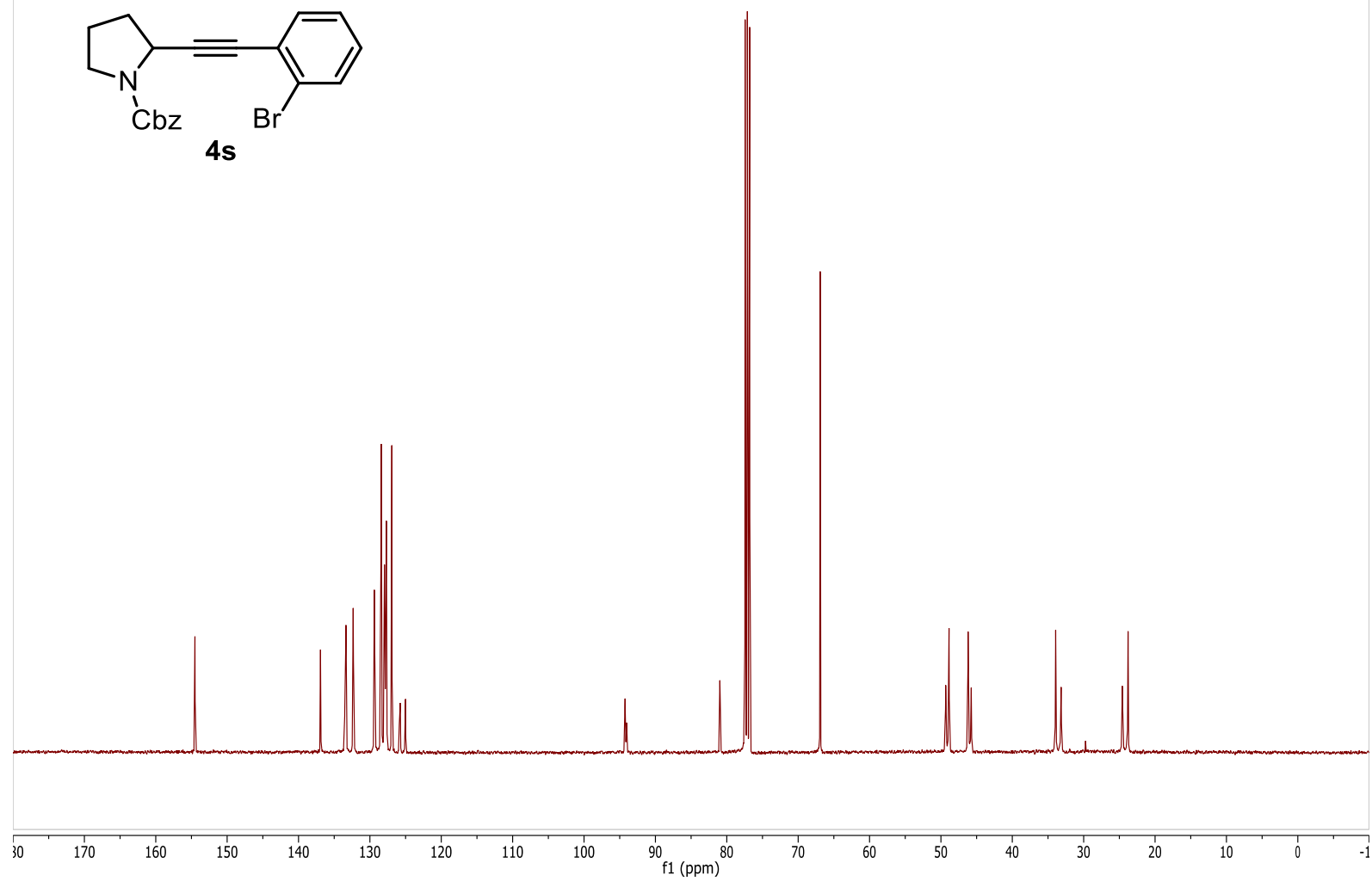


\section{IR Spectra}

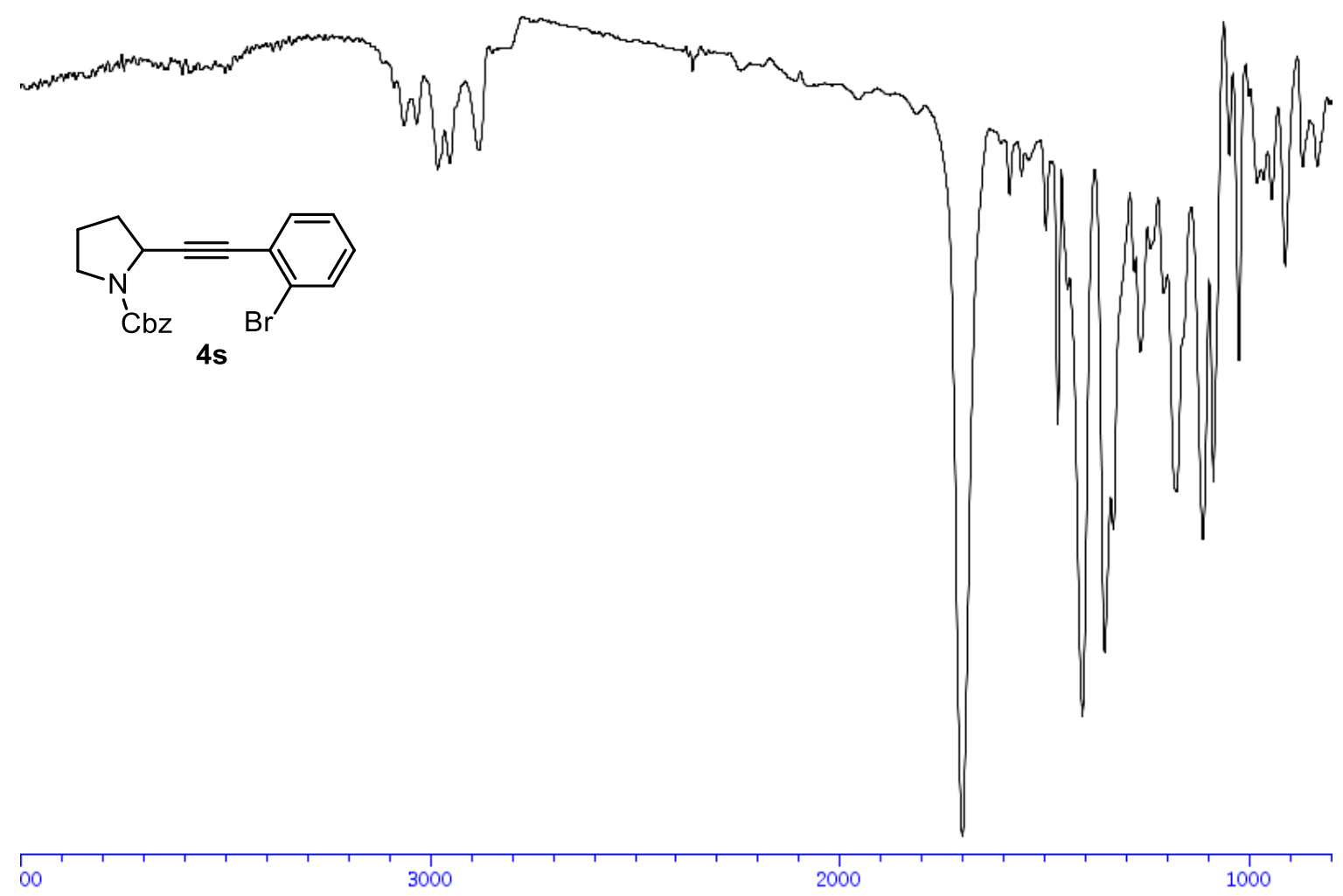


${ }^{1}$ H-NMR (400 MHz, CDCl3)

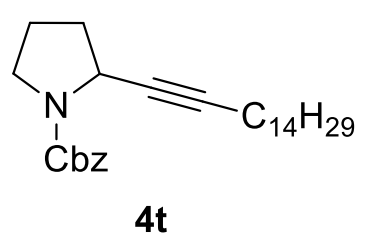
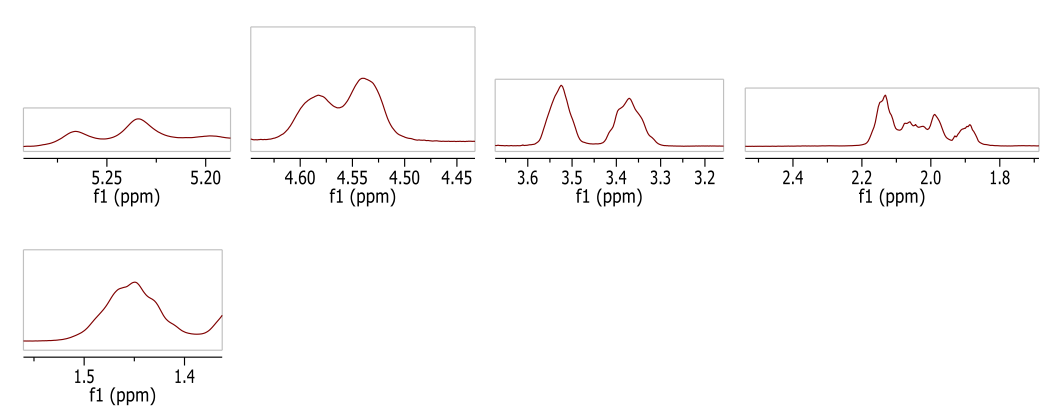

0

8.5

8.0

7.5

6.0

5.5

4.5

4.0
f1 (ppm)

${ }^{13} \mathrm{C}-\mathrm{NMR}\left(101 \mathrm{MHz}, \mathrm{CDCl}_{3}\right)$

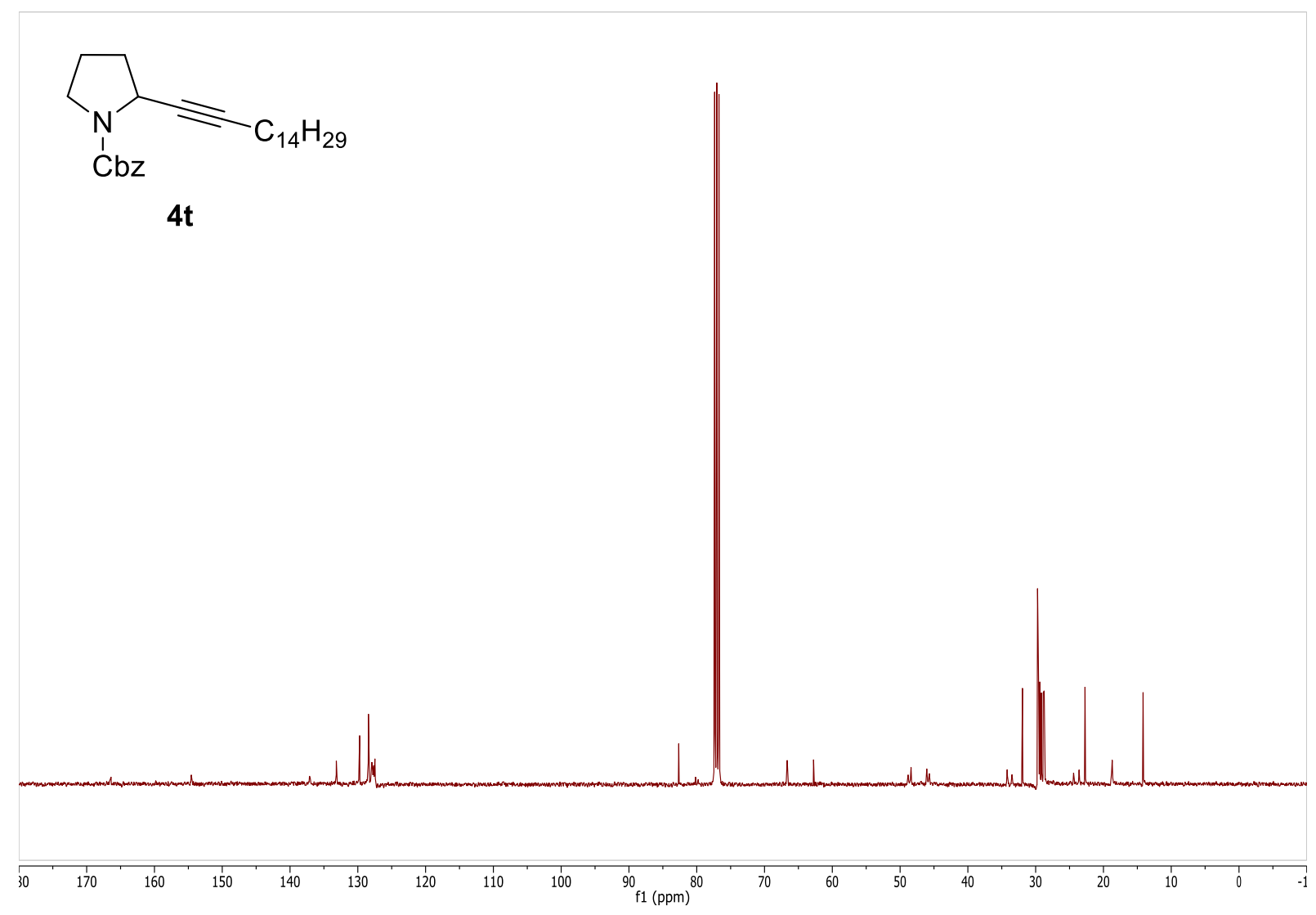

S71 


\section{IR Spectra}

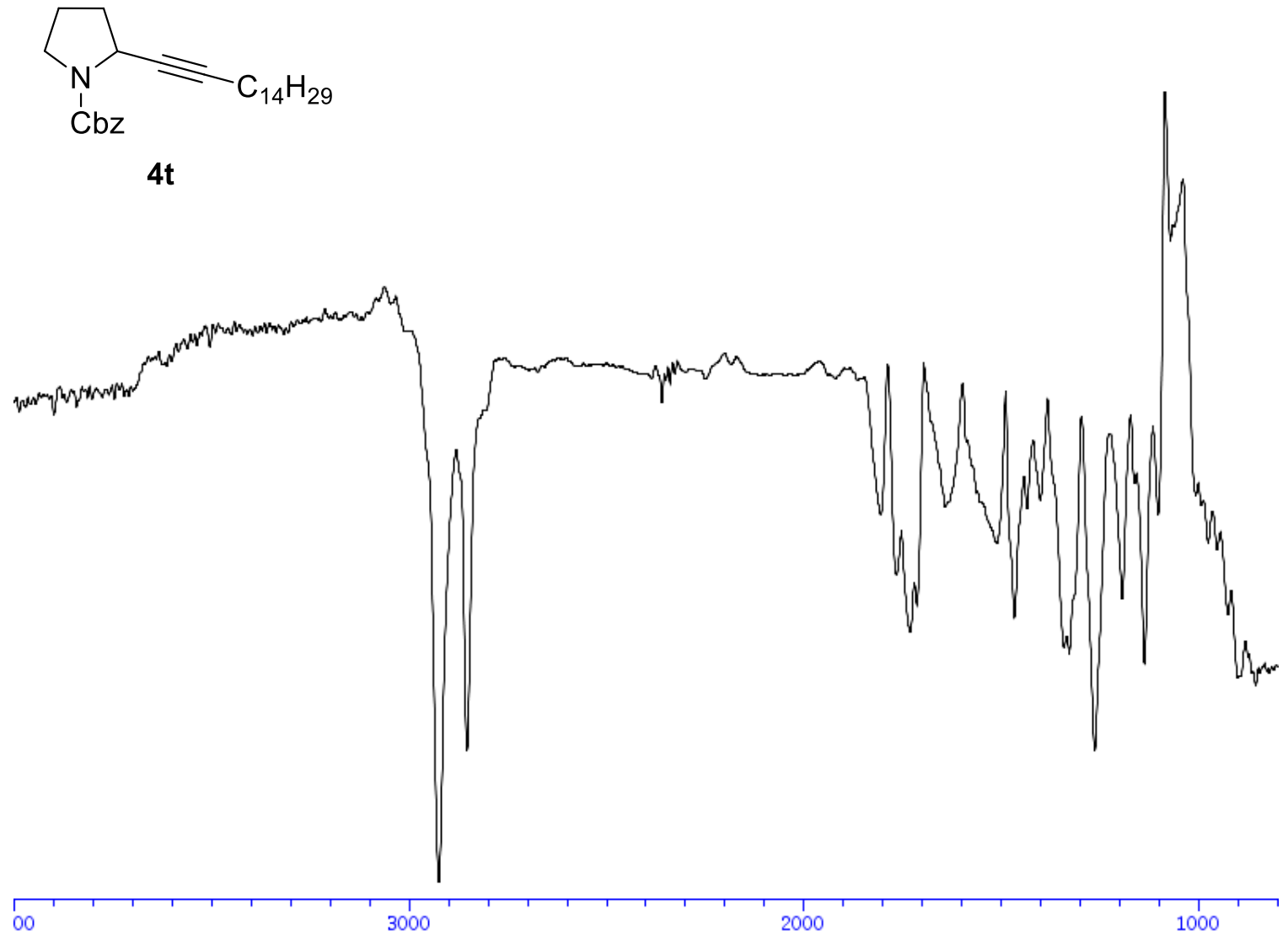


${ }^{1} \mathrm{H}-\mathrm{NMR}\left(400 \mathrm{MHz}, \mathrm{CDCl}_{3}\right)$

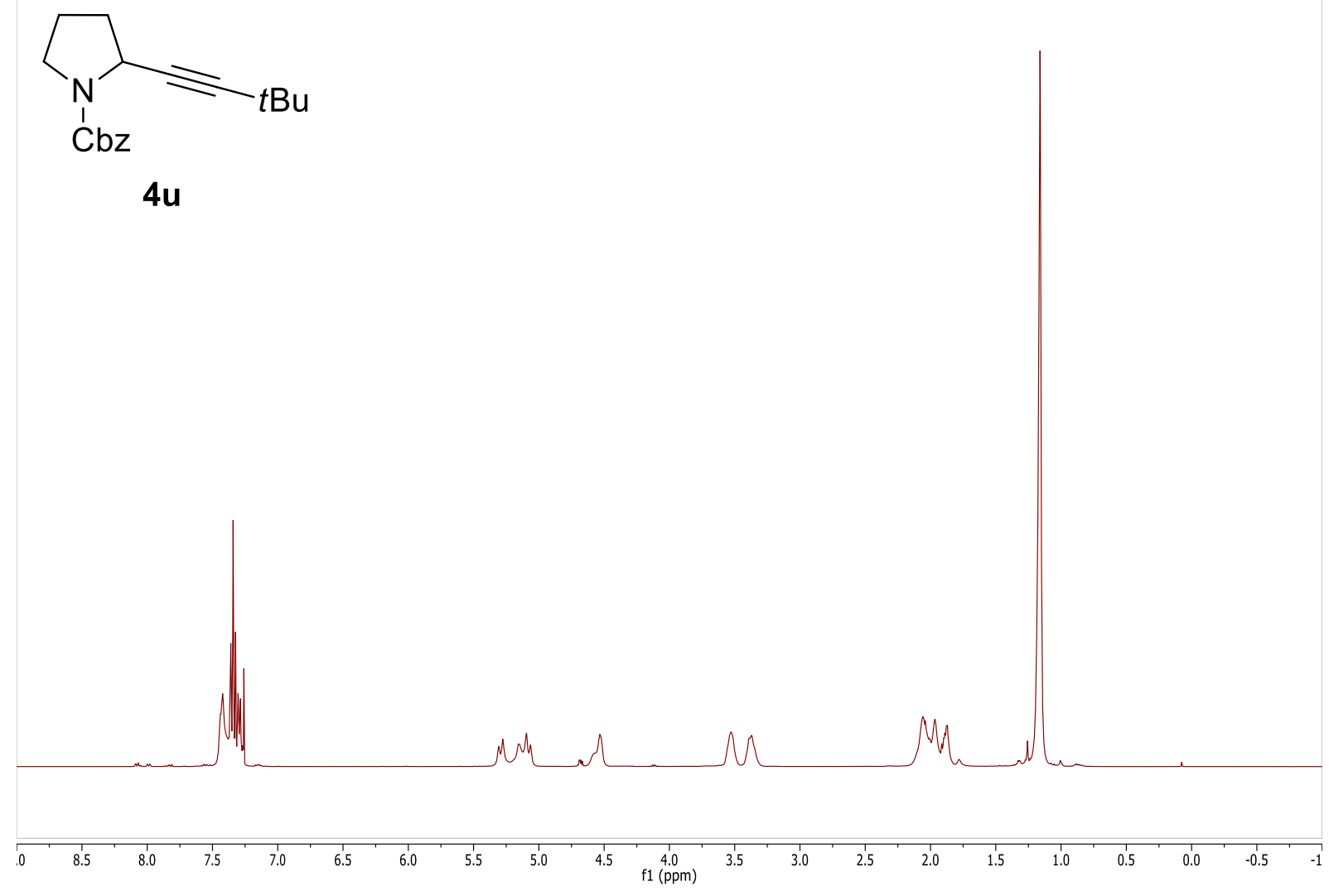

${ }^{13} \mathrm{C}$-NMR (101 MHz, $\mathrm{CDCl}_{3}$ )

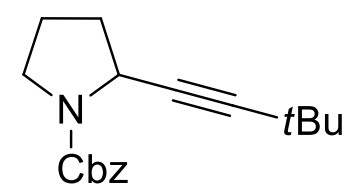

$4 u$
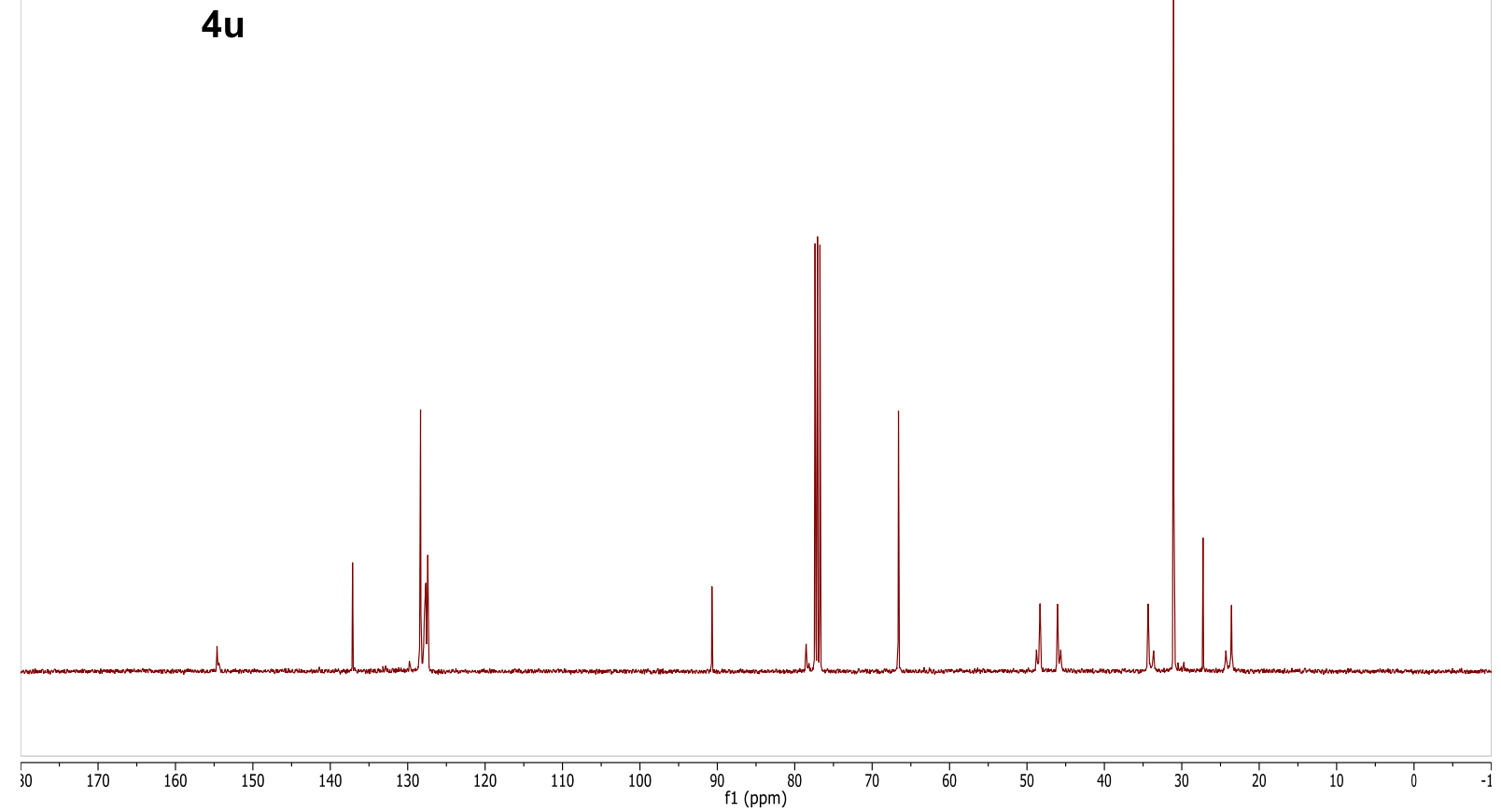


\section{IR Spectra}

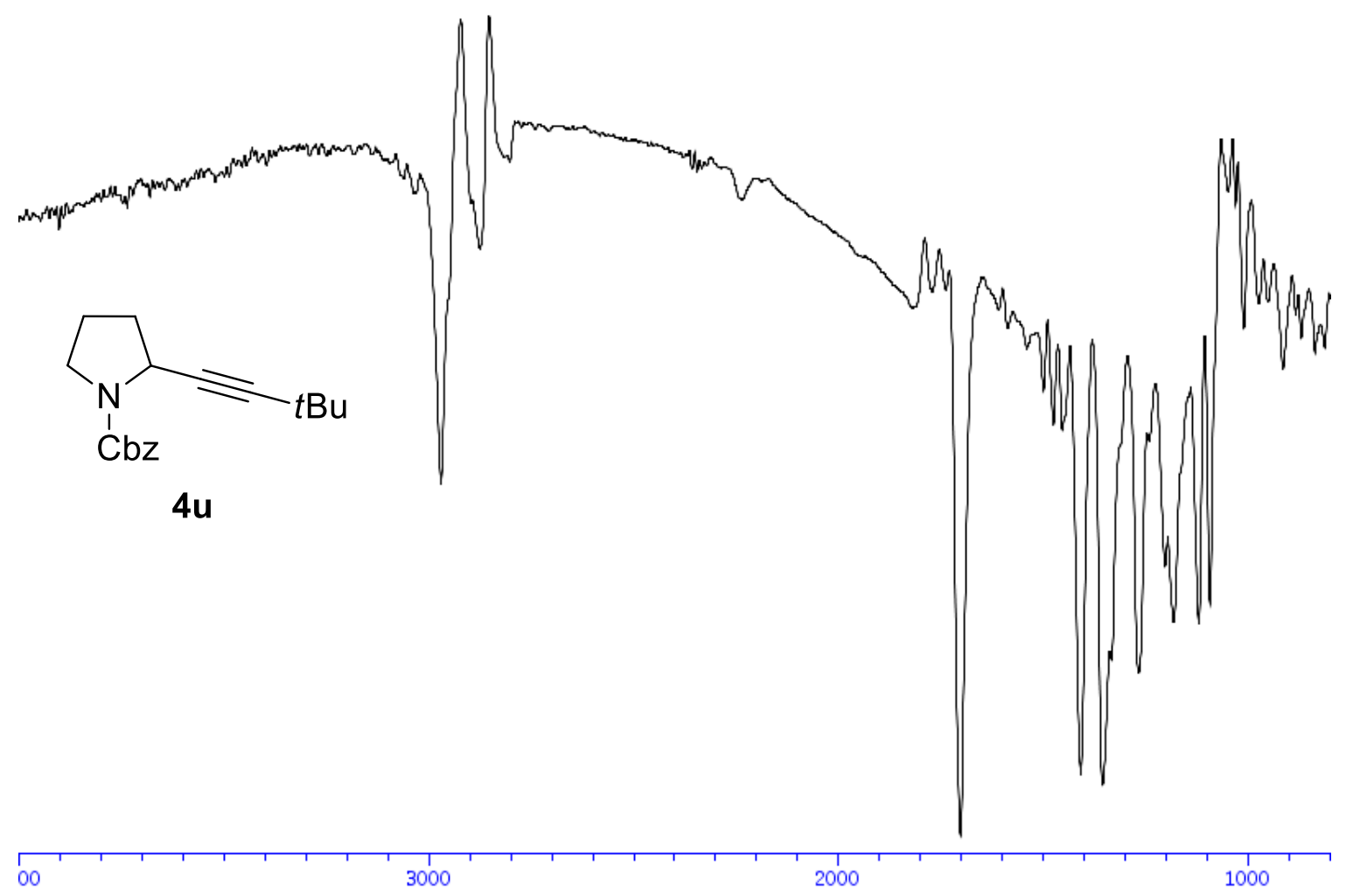


${ }^{1}$ H-NMR (400 MHz, CDCl3)<smiles>O=C(c1ccccc1)N1CCCC1c1cn(Cc2ccccc2)nn1</smiles>

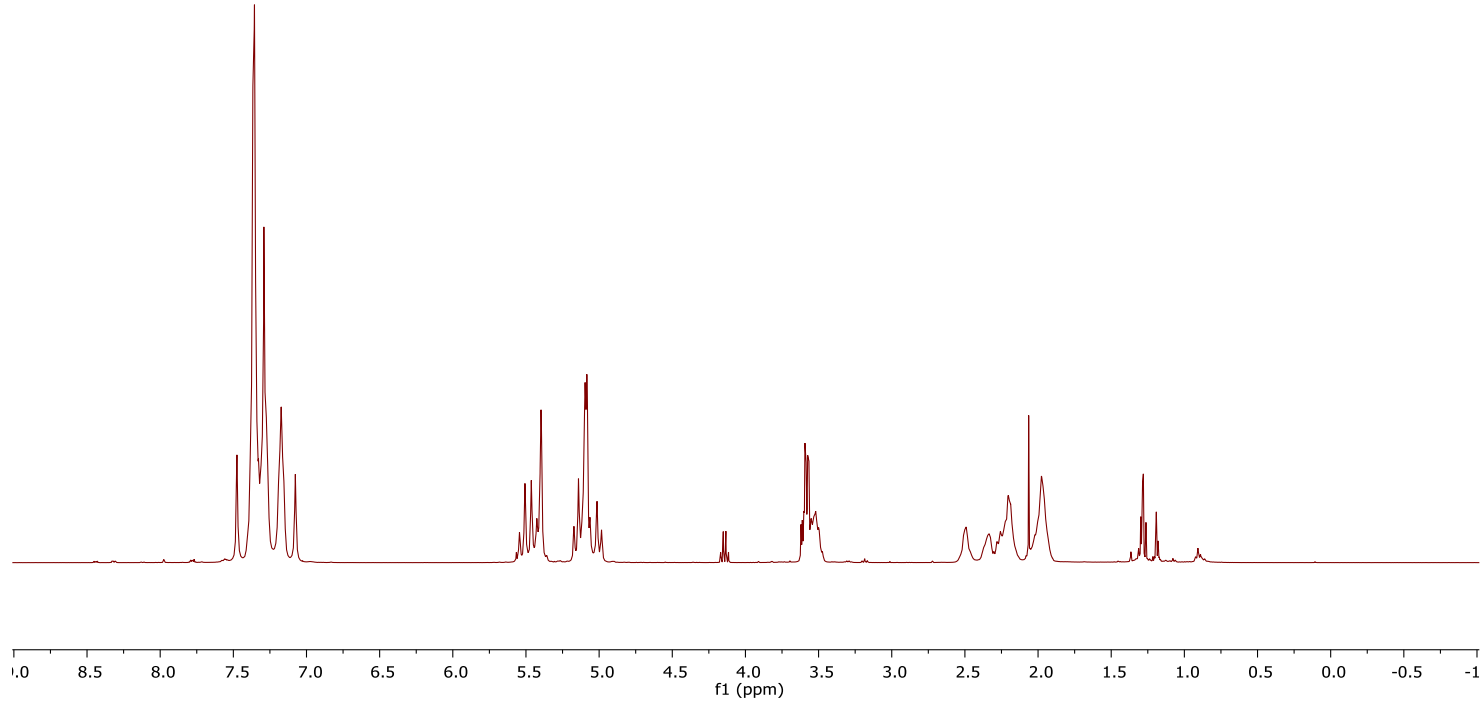

${ }^{13} \mathrm{C}-\mathrm{NMR}$ (101 MHz, $\left.\mathrm{CDCl}_{3}\right)$
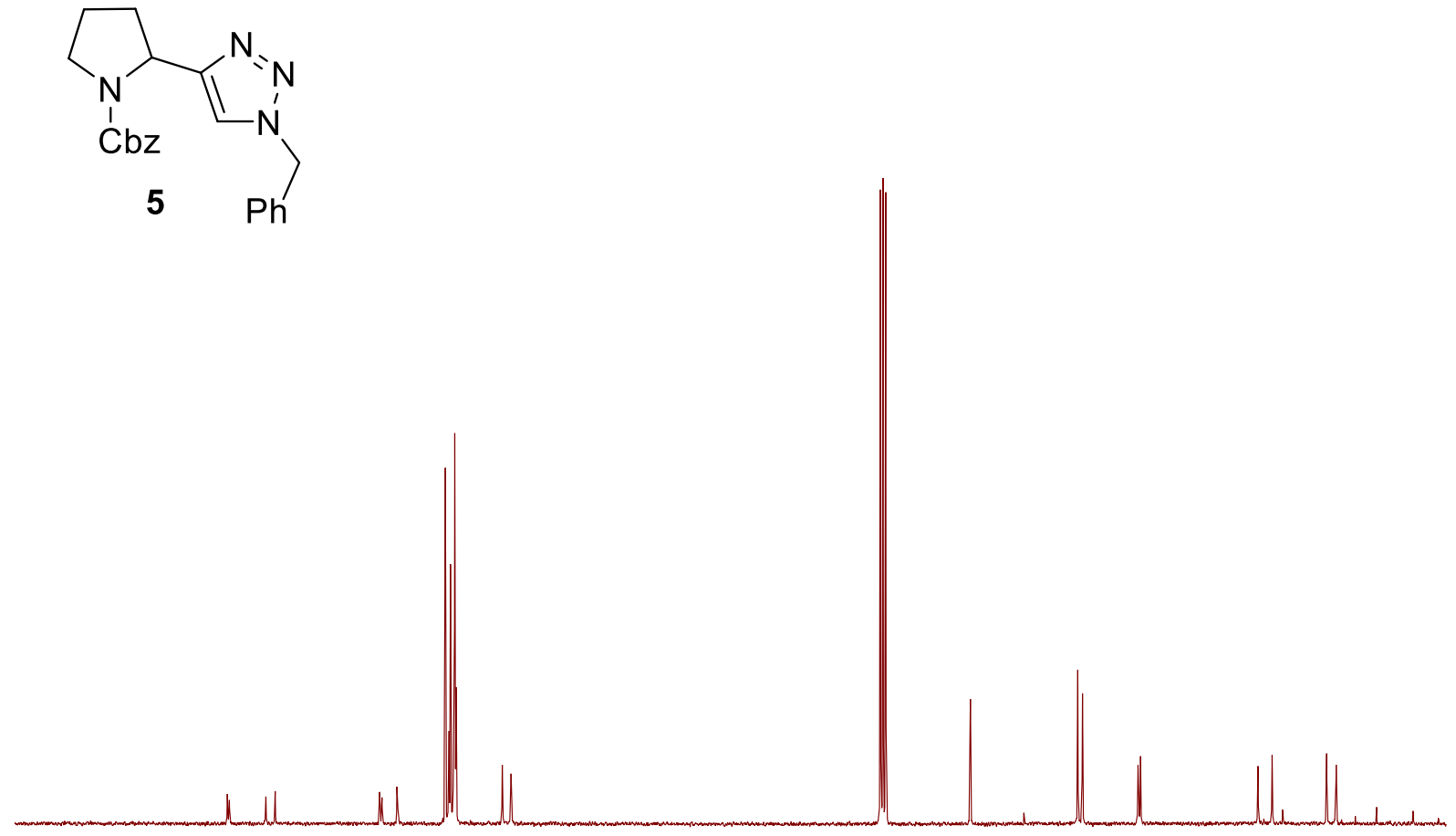

$$
80
$$

$170 \quad 160$

$150 \quad 140$

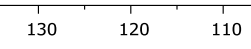

100 f1 (ppm) 90

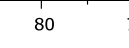

60

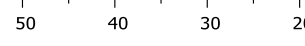

20 


\section{IR Spectra}

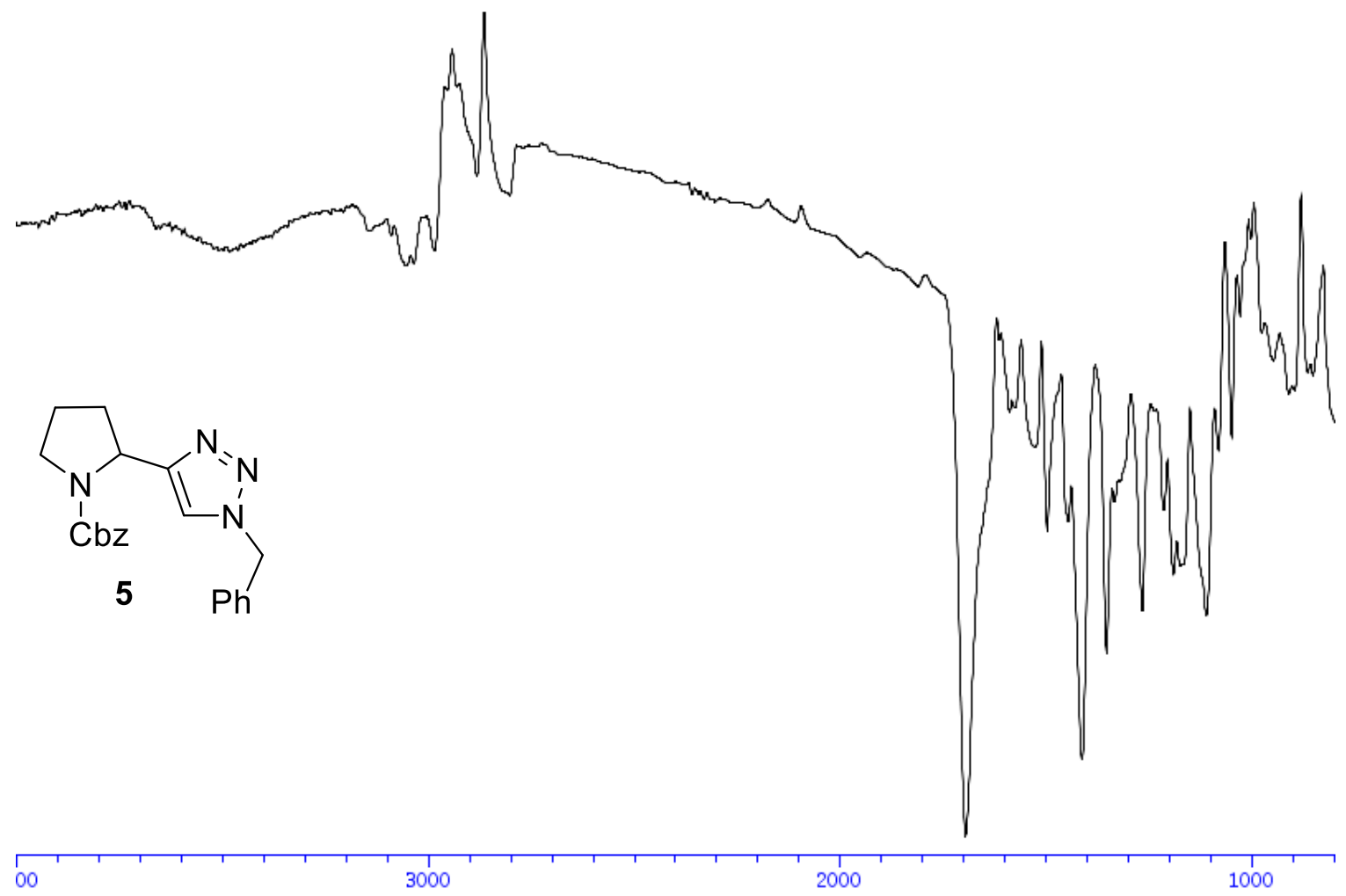

